\title{
MONOGRAPH
}

\section{PEDAGOGY IN MODERN CONDITIONS}
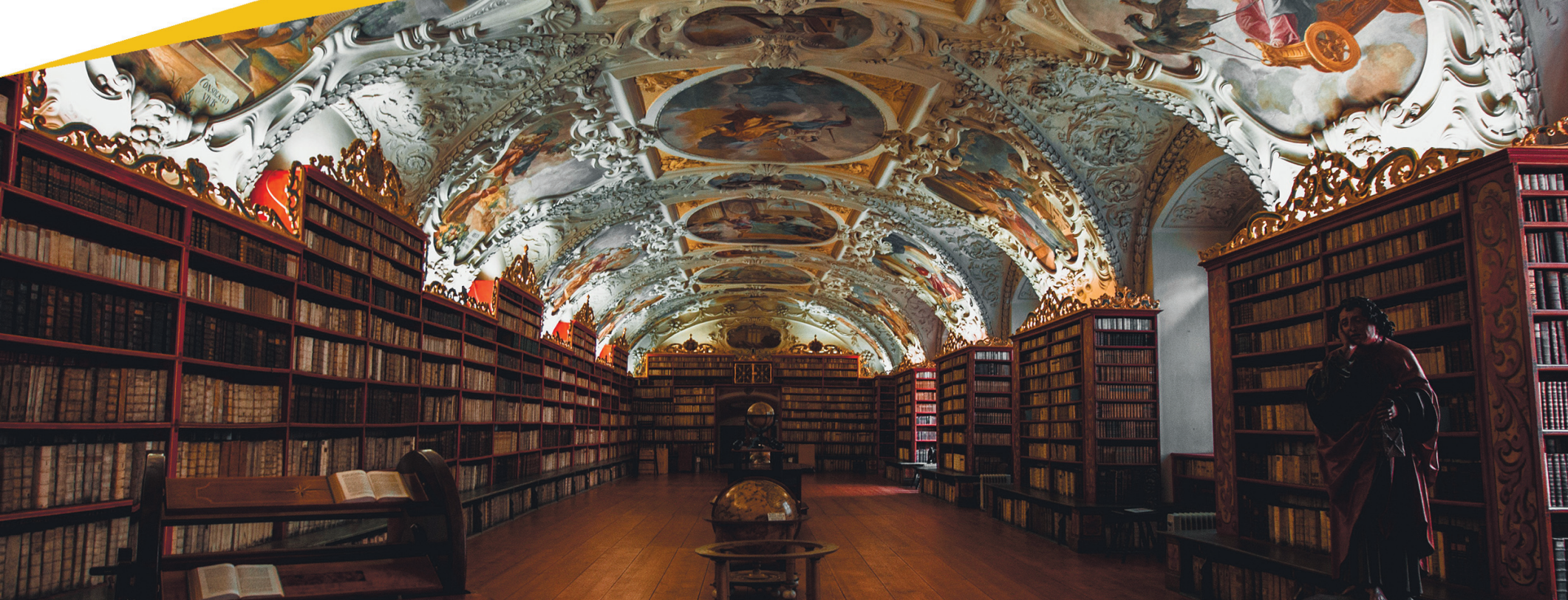

DOI 10.46299/ISG.2020.MONO.PED.III ISBN 978-1-63649-930-7 BOSTON (USA) - 2020 ISG-KONF.COM 
ISBN - 978-1-63649-930-7

DOI- 10.46299/ISG.2020.MONO.PED.III

Pedagagy in madexn conditions

Gollective monograph

Boston 2020 
Library of Congress Cataloging-in-Publication Data

ISBN - 978-1-63649-930-7

DOI - 10.46299/ISG.2020.MONO.PED.III

Authors - Bartienieva I., Nozdrova O., Lappo V., Oleynik O., Kolesnik A., Pyurko V., Korobchenko A., Kazakova S., Ахновська I., Бакіко I., Радченко О., Андрійчук Ю., Гречаник Н.І., Івершинь А., Растригіна А.М., Савка Л., Самохвалова А., Онищенко Н., Трубавіна І., Каліна К., Петришин Л., Шуляр В., Гладишев В., Козак Л., Фунтікова О., Журкіна С.В., Коляда I.В., Захожай З., Плотнікова Н., Семенова Л., Внукова К., Чітішвілі В., Poriadchenko L., Rykalo N., Ivanytsia A., Havrysh Y., Vakulyk I., Бочкова В., Зелинский С.С., Кириленко К.М., Корнієць Н.В., Вовк О.В., Чеботарьова І.Б., Краєвська Н.О., Григор'єв О.В., Ткаченко В.П., Римар Н., Шульська Н., Borisyuk I., Fizor N., Zamkovaya A., Molodan Y., Valivodz I., Garmash S., Sadkovska V., Kireyev I., Zhabotynska N., Kuprikova S., Miroshnyk S., Myronova T., Dekusar G., Simkova I., Bondarenko O., Выдыборец С., Хоменко И., Горяинова Н., Каленик М., Каспрук Н.М., Приступа А.Б., Наритник І.Ю., Новак А.А., Кравчук О.Ю., Бєлоусова С.М., Хлопик І., Цюряк І., Борисенко Н.

\section{Published by Primedia eLaunch https://primediaelaunch.com/}

Text Copyright (C) 2020 by the International Science Group(isg-konf.com) and authors. Illustrations (C) 2020 by the International Science Group and authors.

Cover design: International Science Group(isg-konf.com). (C)

Cover art: International Science Group(isg-konf.com). C

All rights reserved. Printed in the United States of America. No part of this publication may be reproduced, distributed, or transmitted, in any form or by any means, or stored in a data base or retrieval system, without the prior written permission of the publisher. The content and reliability of the articles are the responsibility of the authors. When using and borrowing materials reference to the publication is required.

Collection of scientific articles published is the scientific and practical publication, which contains scientific articles of students, graduate students, Candidates and Doctors of Sciences, research workers and practitioners from Europe and Ukraine. The articles contain the study, reflecting the processes and changes in the structure of modern science.

The recommended citation for this publication is:

Pedagogy in modern conditions: collective monograph / Bartienieva I., Nozdrova O., - etc. - International Science Group. - Boston : Primedia eLaunch, 2020. 329 p. Available at : DOI - 10.46299/ISG.2020.MONO.PED.III 
TABLE OF CONTENTS

\begin{tabular}{|c|c|c|}
\hline 1. & CATION & 8 \\
\hline 1.1 & $\begin{array}{lrr}\text { Bartienieva I., Nozdrova O. } \\
\text { PREPARING FUTURE TEACHERS FOR PROFESSIONAL } \\
\text { COMMUNICATION } & \text { IN } & \text { A } \\
\text { PERSON-ORIENTED } & \text { EDUCATIONAL } & \text { UNIVERSITY } \\
\text { SPACE } & & \end{array}$ & 8 \\
\hline 1.2 & $\begin{array}{l}\text { Lappo V. } \\
\text { FEATURES OF PEDAGOGICAL SUPPORT IN THE } \\
\text { PROCESS OF FORMING THE SPIRITUAL VALUES OF } \\
\text { STUDENTS }\end{array}$ & 17 \\
\hline 1.3 & 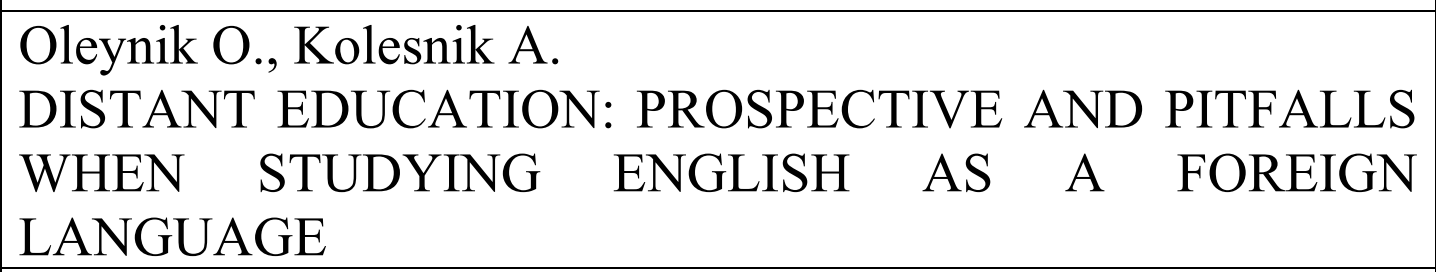 & 23 \\
\hline 1.4 & $\begin{array}{l}\text { Pyurko V., Korobchenko A., Kazakova S. } \\
\text { THEORETICAL AND METHODOLOGICAL PRINCIPLES } \\
\text { OF PROFESSIONAL TRAINING OF SPECIALISTS IN } \\
\text { PHYSICAL THERAPY AND OCCUPATIONAL THERAPY } \\
\text { IN HIGHER EDUCATION INSTITUTIONS OF THE } \\
\text { EUROPEAN UNION }\end{array}$ & 27 \\
\hline 1.5 & $\begin{array}{l}\text { Ахновська І. } \\
\text { МЕТОДОЛОГІЧНІ } \quad \text { ОСНОВИ } \quad \text { ДОСЛІДЖЕННЯ } \\
\text { СІМЕЙНОЇ ФОРМИ ЗДОБУТТЯ ОСВІТИ } \\
\end{array}$ & 31 \\
\hline 1.6 & $\begin{array}{l}\text { Бакіко І., Радченко О., Андрійчук Ю. } \\
\text { ВИЗНАЧЕННЯ ТЕОРЕТИКО-МЕТОДИЧНИХ ЗНАНЬ У } \\
\text { ШКОЛЯРІВ 8-9-ИХ КЛАСІВ У СФЕРІ ФІЗИЧНОЇ } \\
\text { КУЛЬТУРИ І СПОРТУ }\end{array}$ & 40 \\
\hline 1.7 & $\begin{array}{llc}\text { Гречаник Н.І. } & & \\
\text { ТЕОРЕТИЧНІ } & \text { ОСНОВИ } & \text { КУЛЬТУРОЛОГІЧНО- } \\
\text { ОРІСНТОВАНОГО СЕРЕДОВИЩА ФОРМУВАННЯ } \\
\text { КУЛЬТУРОЛОГІЧНОЇ } & \text { КОМПЕТЕНТНОСТІ } \\
\text { МАЙБУТНІХ УЧИТЕЛІВ ПОЧАТКОВОЇ ШКОЛИ }\end{array}$ & 50 \\
\hline 1.8 & $\begin{array}{l}\text { S А. } \\
\text { ЛОГО-ПЕДАГОГІЧН }\end{array}$ & 56 \\
\hline
\end{tabular}




\begin{tabular}{|c|c|c|}
\hline 1.9 & 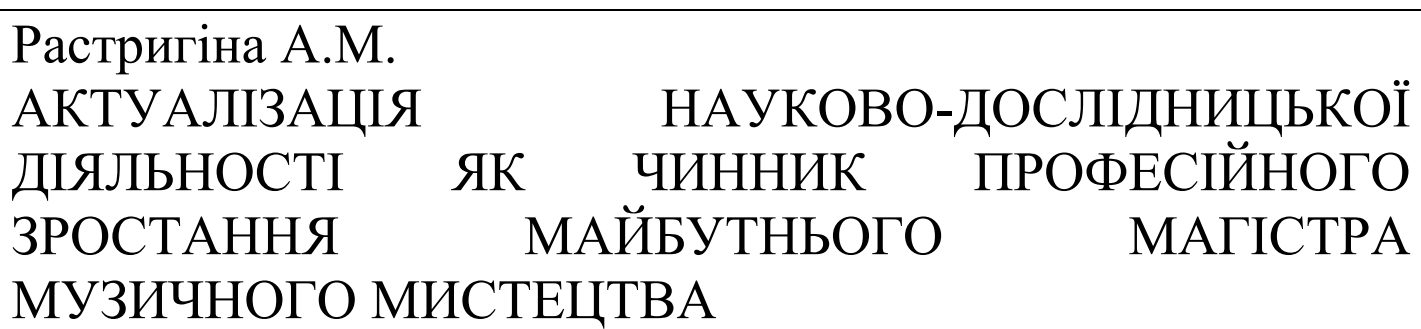 & 55 \\
\hline 1.10 & $\begin{array}{l}\text { СаВКа Л. } \\
\text { ДИДАКТИКО-ВИХОВНІ } \quad \text { АСПЕКТИ } \\
\text { УКРАЇНСЬКОЇ НАРОДНОЇ ВИШИВКИ МАЙБУТНІМИ } \\
\text { ВЧИТЕЛЯМИ }\end{array}$ & 71 \\
\hline 1.11 & $\begin{array}{l}\text { Самохвалова А., Онищенко Н. } \\
\text { ЗНАЧЕННЯ ЕКОЛОГІЧНОЇ ОСВІТИ В СУЧАСНОМУ } \\
\text { ОСВІТНЬОМУ ПРОЦЕСІ ТА ЇЇ ОСОБЛИВОСТІ }\end{array}$ & 82 \\
\hline 1.12 & $\begin{array}{l}\text { Трубавіна І., Каліна К., Петришин Л. } \\
\text { ПОНЯТТЯ СОЦІАЛЬНОГО АНАЛІЗУ ЯКОСТІ ВИЩӦ̈ } \\
\text { ОСВІТИ В КОНТЕКСТІ ФОРМУВАННЯ ПРОФЕСІЙНОЇ, } \\
\text { ЗАГАЛЬНОЇ І СОЦІАЛЬНОЇ КОМПЕТЕНТНОСТІ } \\
\text { ЗДОБУВАЧІВ ОСВІТИ }\end{array}$ & 86 \\
\hline 1.13 & $\begin{array}{l}\text { Шуляр В., Гладишев В. } \\
\text { ПЕДАГОГІЧНА ШКОЛА ВИДАТНОГО МЕТОДИСТА } \\
\text { НІЛИ ЙОСИПІВНИ ВОЛОШИНОЇ }\end{array}$ & 95 \\
\hline 2. & GENERAL AND PRE-SCHOOL PEDAGOGY & 100 \\
\hline 2.1 & $\begin{array}{l}\text { Козак Л. } \\
\text { ФОРМИ ОРГАНІЗАЦІЇ ОСВІТНЬОГО ПРОЦЕСУ } \\
\text { ЗАКЛАДАХ ДОШКІЛЬНОЇ ОСВІТИ }\end{array}$ & 100 \\
\hline 2.2 & $\begin{array}{l}\text { ФУНТікова О. } \\
\text { СУЧАСНІ ПРОБЛЕМИ ДОШКІЛЬНӦ̈ ПЕДАГОГІКИ: } \\
\text { ІНКЛЮЗИВНА ПРАКТИКА РОБОТИ ДОРОСЛИХ } 3 \\
\text { ДІТЬМИ }\end{array}$ & 106 \\
\hline 3. & HISTORY & 112 \\
\hline 3.1 & $\begin{array}{l}\text { Журкіна С.В., Коляда І.В. } \\
\text { ІСТОРИКО-ПЕДАГОГІЧНІ АСПЕКТИ } \\
\text { ІНСТИТУЦІЙНИХ ПЕРЕТВОРЕНЬ У ВИЩЙ ШКОЛІ } \\
\text { США }\end{array}$ & 112 \\
\hline 3.2 & $\begin{array}{l}\text { Захожай } 3 . \\
\text { УКРАЇНСЬКІ НАРОТИВИ С.С. ПРОКОФ'СВА }\end{array}$ & 118 \\
\hline 3.3 & $\begin{array}{l}\text { Плотнікова Н., Семенова Л., Внукова К., Чітішвілі В. } \\
\text { НАЦІОНАЛЬНА СИСТЕМА ОСВІТИ УКРАЇНИ: ТИПИ } \\
\text { ЗАКЛАДІВ ОСВІТИ ТА ДИНАМІКА ЇХ РОЗВИТКУ }\end{array}$ & 124 \\
\hline
\end{tabular}




\begin{tabular}{|c|c|c|}
\hline 4. & INNOVATION IN EDUCATION & 131 \\
\hline 4.1 & $\begin{array}{l}\text { Poriadchenko L. } \\
\text { FORMATION OF COMMUNICATIVE COMPETENCE IN } \\
\text { PRIMARY SCHOOL CHILDREN } \quad \text { BASED ON } \\
\text { PSYCHOLINGUISTICS }\end{array}$ & 131 \\
\hline 4.2 & $\begin{array}{l}\text { Rykalo N., Ivanytsia A., Havrysh Y. } \\
\text { THE USE OF INTERACTIVE TEACHING METHODS FOR } \\
\text { STUDENTS AT THE DEPARTMENT OF PATHOLOGICAL } \\
\text { PHYSIOLOGY OF VINNYTSYA NATIONAL PYROGOV } \\
\text { MEMORIAL MEDICAL UNIVERSITY }\end{array}$ & 138 \\
\hline 4.3 & $\begin{array}{l}\text { Vakulyk I. } \\
\text { INNOVATION IN EDUCATION: } \\
\text { BASES OF LANGUAGE LEARNING }\end{array}$ & 143 \\
\hline 4.4 & $\begin{array}{l}\text { БОчКОВа В. } \\
\text { ВИКОРИСТАННЯ } \quad \text { СУЧАСНИХ ПЕДАГОГІЧНИХ } \\
\text { ТЕХНОЛОГІЙ ЯК ЗАПОРУКА ЯКІСНОЇ ПІДГОТОВКИ } \\
\text { МАЙБУТНІХ ВЧИТЕЛІВ ПОЧАТКОВИХ КЛАСІВ }\end{array}$ & 158 \\
\hline 4.5 & 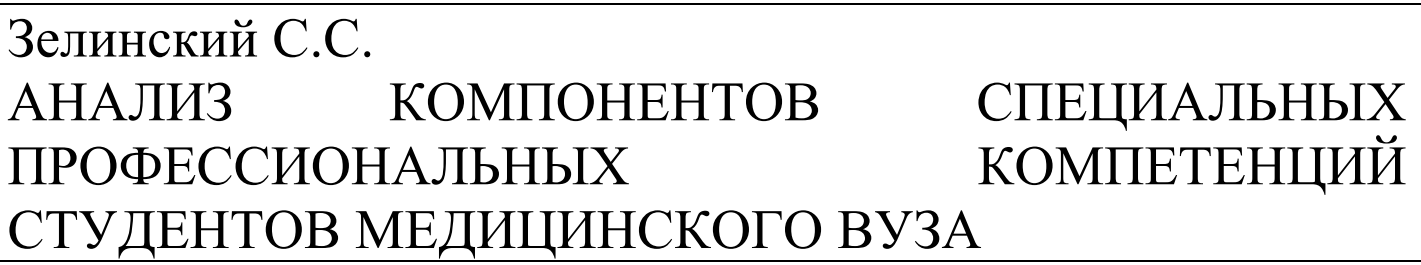 & 162 \\
\hline 4.6 & $\begin{array}{l}\text { КИрИЛТНКО К.М. } \\
\text { НАПРЯМКИ ОСВІТНІХ ІННОВАЦІЙ В УМОВАХ } \\
\text { ІНТЕГРАЦІЇ ГУМАНІТАРНОГО ТА ПРИРОДНИЧОГО } \\
\text { ЗНАННЯ }\end{array}$ & 167 \\
\hline 4.7 & 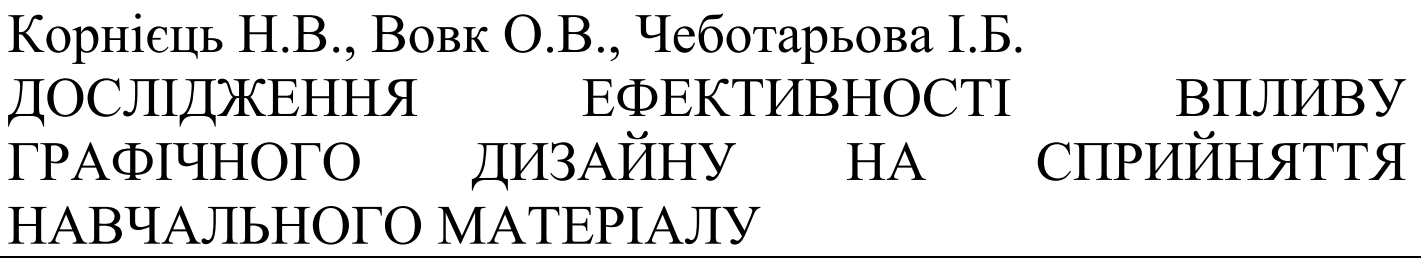 & 176 \\
\hline 4.8 & $\begin{array}{ll}\text { Краєвська Н.О., Григор'єв О.В., Ткаченко В.П. } \\
\text { НАВЧАННЯ } \\
\text { ДОПОМОГОЮ ТРЕНАЖЕРА ОФСЕТНОГО ДРУКУ }\end{array}$ & 186 \\
\hline 4.9 & $\begin{array}{l}\text { Римар Н., Шульська Н. } \\
\text { УПРОВАДЖЕННЯ ВОРКШОПОВИХ ТЕХНОЛОГІЙ У } \\
\text { НАВЧАЛЬНИЙ ПРОЦЕС ЗАКЛАДІВ ВИЩОЇ ОСВІТИ }\end{array}$ & 192 \\
\hline 5. & THEORY, PRACTICE AND TEACHING METHODS & 213 \\
\hline 5.1 & $\begin{array}{l}\text { Borisyuk I., Fizor N., Zamkovaya A., Molodan Y., Valivodz I. } \\
\text { PEDAGOGICAL ASPECTS IN STUDENT EDUCATION }\end{array}$ & 213 \\
\hline
\end{tabular}




\begin{tabular}{|c|c|c|}
\hline 5.2 & $\begin{array}{l}\text { Garmash S., Sadkovska V. } \\
\text { NEW APPROACHES TO TEACHING ENGLISH FOR } \\
\text { SPECIAL PURPOSES }\end{array}$ & 218 \\
\hline 5.3 & $\begin{array}{l}\text { Kireyev I., Zhabotynska N. } \\
\text { MODERN TOOLS FOR THE IMPLEMENTATION OF } \\
\text { DISTANCE LEARNING }\end{array}$ & 222 \\
\hline 5.4 & $\begin{array}{l}\text { Kuprikova S. } \\
\text { CLIL AND CALL TECHNOLOGY APPLICATION TO } \\
\text { IMPROVE QUALITY FORMATION OF STUDENTS' } \\
\text { FOREIGN } \\
\text { COMPETENCE }\end{array}$ & 226 \\
\hline 5.5 & $\begin{array}{l}\text { Miroshnyk S. } \\
\text { COMPARATIVE ANALYSIS OF TRANSLATOR } \\
\text { TRAINING IN HIGHER EDUCATIONAL INSTITUTIONS } \\
\text { OF UKRAINE AND SPAIN }\end{array}$ & 234 \\
\hline 5.6 & $\begin{array}{l}\text { Myronova T., Dekusar G. } \\
\text { ON SOME GENDER } \\
\text { COMMUNICATIVE ISSUES }\end{array}$ & 241 \\
\hline 5.7 & $\begin{array}{l}\text { Simkova Iryna, Bondarenko Oleksandra } \\
\text { THE DEVELOPMENT OF PROFESSIONAL WRITING } \\
\text { SKILLS DURING ENGLISH FOR SPECIFIC PURPOSES } \\
\text { COURSES FOR FUTURE INFORMATION TECHNOLOGY } \\
\text { SPECIALISTS }\end{array}$ & 246 \\
\hline 5.8 & $\begin{array}{l}\text { ВЫдыборец С., Хоменко И., Горяинова Н. } \\
\text { СОВРЕМЕННАЯ ЛЕКЦИЯ В В МЕДИЦИНСКОМ } \\
\text { ПОСЛЕДИПЛОМНОМ ОБРАЗОВАНИИ }\end{array}$ & 257 \\
\hline 5.9 & $\begin{array}{l}\text { Каленик М. } \\
\text { МЕТОДИКА ФОРМУВАННЯ УМІНЬ } \quad \text { В } \quad \text { УЧНІВ } \\
\text { РОЗВ'ЯЗУВАТИ ФІЗИЧНІ ЗАДАЧІ }\end{array}$ & 263 \\
\hline 5.10 & $\begin{array}{l}\text { Каспрук Н.М., Приступа А.Б., Наритник І.Ю., Новак А.А. } \\
\text { ОРГАНІЗАЦІЯ НАВЧАЛЬНОГО ПРОЦЕСУ В } \\
\text { МЕДИЧНОМУ ВНЗ }\end{array}$ & 272 \\
\hline 5.11 & $\begin{array}{l}\text { Кравчук О.Ю., БєЛоусова С.М. } \\
\text { ОСОБЛИВОСТІ ВИКЛАДАННЯ СУСПІЛЬНИХ НАУК У } \\
\text { ЗАКЛАДАХ ВИЩОЇ ОСВІТИ }\end{array}$ & 278 \\
\hline .12 & $\begin{array}{l}\text { ЦІЙНИМИ ТЕХНОЛОГІЯМИ, } \\
\text { ЗСТИЧНИМИ НАУКАМИ }\end{array}$ & 287 \\
\hline
\end{tabular}


PEDAGOGY IN MODERN CONDITIONS

\begin{tabular}{|l|lrr|c|}
\hline 5.13 & \multicolumn{3}{l|}{ Цюряк І., Борисенко Н. } & 293 \\
ПЕДАГОГІЧНІ & УМОВИ & ТА & МЕТОДИ & \\
ВДОСКОНАЛЕННЯ & ДИРИГЕНТСЬКО-ХОРОВӦ̈ & \\
ПІДГОТОВКИ & МАГІСТРІВ & МИСТЕЦЬКИХ & \\
СПЕЦІАЛІЗАЦІЙ & & 300 \\
\hline
\end{tabular}




\section{SECTION 1. EDUCATION}

\subsection{Preparing future teachers for professional communication in a person- oriented educational university space}

Teacher training in the conditions of modernization of education and innovative pedagogical technologies in the field of fundamental open and continuous education is training of the teacher of corresponding level and profile, competitive in the labor market. We want to note that a teacher of new generation is a person who is psychologically and emotionally competent. That is, the teacher is a person who understands and accepts the individual trajectory of students' development and their needs; a cheerful person who knows how to create a positive learning; a tolerant, impartial mentor who understands the inner world of others.

A characteristic of a modern teacher - leader and manager. This is a person who takes responsibility for the success of his student, works effectively in a team with other colleagues; is an adviser, friend and helper for students; constantly learns and develops in various ways; bearer of high ethical standards (i.e. teaches by own example).

This is a successful person free from stereotypes. That is, the teacher is able to create an environment for effective learning and disclosure of student's talent; finds interesting material for classes; successfully realizes himself in work; creative, active, flexible (responds quickly to changes in the environment).

A modern teacher must have presentation skills, be an effective communicator. The teacher is linguistically competent, i.e. clearly, accessibly states the material, uses new technologies, methods, tools in the educational process; supports the principle of joint responsibility - teacher + parents.

The teacher must form the knowledge and skills needed in the modern educational space - cultivate students in leadership and teamwork skills; to develop critical thinking and problem-solving skills; to give the right to choose and learn to take 
responsibility for choice, as well as to demonstrate his own skills that help to succeed in today's educational space.

In pedagogy and psychology of higher school is constantly investigated the professional and pedagogical preparation of the future teacher as competent, capable of self-development person (O.I. Pometun); preparation of the future teacher for work in the conditions of education reform (E.G. Kostyashkin); general principles of organization of the pedagogical process and the main directions of constructing the content of psychological and pedagogical training, which provides the formation of a teacher-researcher who is in constant search of effective and rational methods of teaching and education (A. Boyko); formation of the creative personality of the future teacher (V.O. Kan-Kalik); organization of professional self-education of future teachers (V.I. Maslov). However, the problem of forming professional communication between teachers and students in the personality-oriented educational university space is insufficiently covered in scientific sources.

Thus, the purpose of the article is to study the peculiarities of professional communication styles of the future teacher in the personality-oriented educational university space.

The key educational competencies of a specialist are a set of his personal qualities, general culture and qualification knowledge, skills, methodological mastery, the harmonious integration of which in pedagogical activities gives the optimal result [1]. Personality-oriented approach in the process of professional communication determines the organization of future teachers activity on the basis of comprehensive consideration of their individual needs and capabilities.

The inner qualities of personality are put forward: personal qualities, i.e. the structure of personal abilities and character traits, general culture, management and organizational capabilities, and only after it - qualification competence, which involves knowledge, skills, abilities in the specialty [3]. The formation of professional communication of the future specialist in the personality-oriented educational university space is a complex multilevel stable structure of his mental traits, formed as a result of integration of experience, theoretical knowledge, practical skills, personal 
qualities significant for the teacher, and have certain essential features (mental mobility, flexibility and criticism) [2].

As evidenced by numerous pedagogical studies (V.I. Bondar, L.V. Zikov, M.I. Zhaldak, L.M. Karamushka, V.I. Maslov, O.I. Pometun), professional communication of the specialist includes the following elements: instrumental components (knowledge, skills, activity, independence, individuality) and personal qualities (tact, sociability, friendliness. emotional balance) [2].

The reform of secondary and trade schools requires the intensification of pedagogical creativity and research work of teachers and students, becomes a necessary condition for modern requirements to teacher training.

Improving of the system of specialist training does not take into account all the possibilities of his research activities. Research work is a pedagogical driver of professional development.

The role of the scientist-teacher in this process is significant and important.

Resolving the contradictions of the modern pedagogical process is possible through taking into account the laws of dialectical interaction of social and individual values, which allow to overcome such characteristics of the traditional educational system as authoritarianism, lack of dialogue, isolation. Ukrainian scientific schools should focus on the use of such tactics, techniques and methods of "scientific and developmental" strategy of influence, which would be implemented in an open dialogue between teacher- scientist and student. This would create optimal conditions for the development of positive motivation for research and study [1]. Learning and educating are creative processes in which conditions are created for "self-development and self-learning, deliberate definition of one's own capabilities and life goals" [3]. The formation of professional communication of a specialist should take place in a personality-oriented educational space.

Personality-oriented learning requires, above all, the creation of conditions for each student for self-development, creative self-realization, stimulation of research work.

Among these priorities are: 
PEDAGOGY IN MODERN CONDITIONS

- ensuring students' awareness of the tasks and requirements of the future profession in a scientific perspective;

- formation in future specialists of professional and psychological orientation of the individual;

- organization of research activity of each student;

- taking into account in the process of interaction with students the individual characteristics of everyone;

- maximum use of research, creative, interactive methods in the educational process;

- organization of managed, independent research work of students.

It is also necessary to dwell on the professional communication of teachers with students in the personality-oriented educational space.

Pedagogical competent communication removes negative emotional tension from pupils (fear, uncertainty); it should evoke joy, the desire to work together.

We describe the levels of communication that may be inherent in teachers:

1) Primitive - the attitude to the student is based on primitive rules and reactions of behavior - ambition, complacency, malice. The teacher demonstrates his superiority [2].

2) Manipulative - the relationship with the student is based on the game, the essence of which is the desire to win, using various techniques, flattery. The student is the object of manipulation. He is intimidated, infantile.

3) Standardized - the formal structure of communication dominates. There is a weak focus on personality; the teacher adheres to the standards of etiquette, but such behavior is superficial.

4) Business - focusing on the case, the teacher takes into account the personal characteristics of the student only in the context of efficiency. The teacher adheres to the standards of etiquette, recognizes the student's right to independence. He is important for the teacher depending on the contribution to the joint activity.

5) Personal - communication is based on a deep interest in the student's personality, recognition of his independence. All activities of the teacher are aimed at 
PEDAGOGY IN MODERN CONDITIONS

the development of the student's spirituality, personal communication becomes spiritual communication. Students trust the teacher, he is an authority for them.

Each of the future professionals must create his own style of communication. Today there are many classifications of styles of teachers activity. E.G. Kostyashkin defines the following four types according to the level of professional ethics and peculiarities of activity: "intellectual", "volitional", "emotional", "organizational" [2]. V.O. Kan-Kalik abstracted negative models of behavior of teachers in the classroom: "Mont Blanc" - the teacher "as a mountain peak over the student"; "Great Wall of China" - distance, limited communication; "Locator" - the teacher builds relationships selectively, with those whom he likes; "Hamlet" - the teacher is constantly hesitant in his own actions; "Deaf person" - hears only himself [3]. A. Boyko, analyzing the behavior of the teacher in combination with his pedagogical activity and its results identifies models of educational relationships between teachers and students. Figuratively, they are called: "Optimist", "Objectivist", "Erudite person", "Talent", "Craftsman", "Soul", "Artist" [2].

For teachers of any model of interaction, emotional and aesthetic expressiveness, the ability to present themselves and create an atmosphere of self-expression and selfaffirmation are important. An experienced teacher, as a rule, has a noticeable tendency to one or another model, the type of relationship that most fully corresponds to his individual psychological characteristics. A teacher with a high culture of communication is characterized by: optimal requirements; pedagogical optimism; emotional response; formation of collective forms of relations in the team in the educational process; creating an atmosphere of friendliness [2].

According to scientists (V.O. Kan-Kalyk, V.I. Maslov) effective pedagogical communication depends on the communication situation. It is difficult to effectively solve the problem of increasing the level of interpersonal relations in the real team, without knowing its value orientations - both in general and at the level of its specific representatives. On the other hand, the productivity of pedagogical communication largely depends on psychological factors: the individuality of the participants in the 
PEDAGOGY IN MODERN CONDITIONS

communicative process, communication style, characteristics, temperament, age, abilities and interests [4].

The study identified difficulties that arose in the process of pedagogical communication:

1. The low level of pedagogical tact was expressed in the insufficient ability to find optimal measures of educational influence in any situation (including conflict), without degrading the student and not causing his resistance to education, which required the teacher to constantly monitor his own behavior and skills for anticipate the possible consequences of his educational influences.

2. Manifestation by the teacher of irritability, excessive emotionality in communication.

3. Inability to notice, see, detect inconspicuous but significant external signs of student's behavior and on this basis to correctly interpret his actions, adequately perceive, understand him.

4. In the process of interaction there was indifference to the student's opinion (low interest), a suppression of his initiative [3].

Characterizing the general conditions of educational activities, we noted that the main difficulties were associated primarily with interpersonal relationships, then with individual psychological characteristics of communication, and only after with the nature of participation in activities.

Difficulties in pedagogical communication were positive and negative. Thus, on the one hand, the difficulties helped to attract the teacher's attention, to activate the teacher's activity in the analysis and overcoming of difficulties, to gain experience. On the other hand, if there were no conditions for overcoming difficulties, such difficulties could restrain the teacher or, in general, could lead to the termination of pedagogical activity.

Difficulties in pedagogical communication (especially for teachers- beginners) were called psychological barriers, which, interfering with normal communication, affected all pedagogical and educational activities of all its subjects [4]. V.A. Kan- 
PEDAGOGY IN MODERN CONDITIONS

Kalik identified three groups of the most typical barriers of pedagogical communication:

- the first group - fear of the group and pedagogical errors;

- the second group - the installation, which was formed as a result of past negative experience in general and work with this group in particular; discrepancies in the teacher's instructions on group work and students' attitudes;

- the third group - the inadequacy of the teacher in the communicative situation, which was formed in the group [3]. A. Markova singled out:

- barriers to planning, setting and solving pedagogical tasks, adequate analysis and prevention of pedagogical errors, narrowing and simplification of the content of educational material, which became a factor in formalizing the lesson, conducting it in a reproductive form;

- barriers to pedagogical influence and interaction with the subjects of activity, not involved in communication, which felt discomfort;

- barriers to the combination of productive and reproductive forms of work, problem-based learning, active learning methods [1]. Some scientists have classified barriers into external and internal.

Thus, V. Kunitsyna and N. Kazarinova attributed to the external barriers the difficulties of a social nature, which were caused by mistakes of upbringing, conditions of communication, unsuccessful experience of emotional and social contacts [2].

Internal barriers - the personal characteristics of those who studied: aggression, anxiety, tension, shyness. They noted that there was a close relationship between external and internal barriers. As the psychically reproduced, the external barriers turned out in internal ones. At first they were fixed in the emotional-sensory, then in the cognitive sphere, and thus extended their influence to other types of human activity. They were conditional obstacles only in certain situations when the level of development of the subject did not allow him to successfully solve certain problems [3].

The analysis of these difficulties in pedagogical communication determined the organization of the activities of future teachers in the educational university space. 
The implementation of a personality-oriented approach in the educational process in course of professional communication has determined the organization of future teachers activity on the basis of comprehensive consideration of their individual needs and capabilities, attitude to them as to conscious and responsible subjects of educational interaction. The essential characteristic of personality-oriented learning was the creation of conditions for individual self-realization, the development of personal qualities, the formation of a value worldview. The educational process was based on the recognition of the principle of pedagogical interaction, stimulation of individual and collective creativity [4]. The system of higher education actualized humanistic pedagogy, focused on the individual. We characterize its distinctive features: shifting priorities to the development of mental, physical, intellectual, moral and other areas of personality instead of mastering the amount of information and the formation of a certain range of skills and abilities; focusing on the formation of a free, independent thinking and acting personality, a citizen who is able to make wellgrounded choice in a variety of educational and life situations [3].

The technology of conducting personality-oriented lessons by students, taking into account the personal style of communication during the "master classes" had the following structure: creating an attractive goal; surprise; fantastic situation; gaming educational activity; creative and exploratory activities. Let's focus on various teaching methods in the classroom, taking into account the personality-oriented aspect of communication.

At the stage of mastering, formation of skills and abilities, we gave tasks to choose from: means of educational activities (individually, face to face or in a group, written or oral); means of new material fixation (scheme, plan, table, conclusions, etc.); tasks and ways its performing.

At this stage of the lesson the following methods were used: encouragement; educational and cognitive game; creation of a situation of success, interest in learning; problem situation: vivid visual representations; situation of mutual assistance; performing of creative tasks, etc. The control of knowledge took place by means of group and pair forms of mutual control and mutual analysis, self-analysis and self- 


\section{PEDAGOGY IN MODERN CONDITIONS}

control (correction of mistakes by students, comprehension of their reasons); mutual and self-assessment (verbal, rating etc.).

Conclusion. On the base of selected communication styles, we have identified certain models of interaction in professional communication of future professionals, which are crucial in the educational personality-oriented university space. Taking them into account, we hope to achieve significant results. Analyzing the causes of arising barriers to pedagogical communication, we identified following ways to overcome them:

- knowledge of difficulties encountered in communication and their timely detection;

- development of pedagogical observation, development of a flexible style of communication;

- use of methods of psychological self-regulation, improvement of own social and psychological culture;

- creating an optimal socio-psychological climate in the team;

- intonation of speech, the possibility of nonverbal manifestations. 


\subsection{Features of pedagogical support in the process of forming the spiritual values of students}

An important condition for the formation of the spiritual values of students of higher educational institutions is the pedagogical support of students in moral selfdetermination, manifestation of spiritual values.

Pedagogical support of the personality is the subject of consideration in the context of various psychological and pedagogical areas: the concept of "relations that help" of Rogers, the existential psychology and pedagogy (Binswanger, Frankl, Bolnov, Barret and others), the idea of "strengthening the existence of another" of S. Rubinstein, the concept of the personalization of Petrovsky and supersituative activity of Petrovskyi (Petrovskyi, 1978).

Under pedagogical support, we understand the activities of educational process subjects, which are aimed at providing preventive and operational assistance. The psychological aspect of such activities consists in participation in life's selfdetermination, in the preparation for the moral choice in crisis situations, in selfdisclosure and in the elimination of subjective obstacles to development, as well as in providing assistance in specific situations. Pedagogical support can be a necessary stage of development, relatively free from the forming role of another and closest to an independent organization (Asmolov). The purpose of pedagogical support in the formation of spiritual values of students of higher educational institutions is to eliminate the obstacles that arise in the way of the personal formation of pupils. In the broad sense, pedagogical support consists in creating favorable conditions for the development of students' moral consciousness, the disclosure and realization of their potential, the formation of the ability to act independently and moral selfdetermination. In our study, we consider pedagogical support as an important condition for the formation of the spiritual values of students of higher educational institutions

Pedagogical support of students for the formation of spiritual values should have a systemic character and include the following factors: the need to optimize communication and increase the level of teacher's personal development; the opportunity to reveal an individual style of communication; the presence of a flexible 
and creative approach to the problems of educational interaction; the desire of subjects to self-develop.

In the individual support of the student in terms of revealing spiritual values, several interrelated stages can be distinguished: diagnostic - clarification of the problems of understanding and producing spiritual values in relationships; search - a joint search for causes and methods of solving problems of identifying spiritual values in relationships; designing - the establishment of relationships with the aim of approaching the solution of the problem of identifying spiritual values in relationships; activity - interaction of the teacher and the student in the construction of personal algorithm for identifying spiritual values in relationships; reflexive - an analysis of joint activities on the problem of identifying the spiritual values of the student, discussion of the results obtained, ways of solving the problem. Each stage of pedagogical support involves the development of various forms, methods, means of educational activities, with the help of which pedagogical support for the student is provided in order to form his spiritual values.

The basic principles of providing pedagogical support in the formation of the students 'spiritual values are their consent to the assistance and support, orientation towards the students' ability to choose on his own the identification of the actiondignity, action-tolerance, action-responsibility, action-mercy in their relationships.

Pedagogical support for students can also be defined as the assistance of a teacher, curator of an academic group, aimed at forming a deep inner motivation for the formation of spiritual values, self-education and facilitating adaptation to the conditions of a real educational process in a higher educational institution. All this will contribute to a clear awareness of the students of their own individual, potential features.

Implementation of the conditions of pedagogical support is carried out in the educational process of a higher educational institution according to the following principles:

1) the principle of facilitation (providing a group of professional support teachers, curators of the academic group, methodologists); 
2) the principle of dialogicity of interactions (the interaction of all participants is the nature of a dialogue in which each participant has equal opportunities to speak and everyone can be heard);

3) the principle of reflexivity (making by a student and a group of support the analysis and correction of their own behavior and interaction with groupmates);

4) the principle of personally oriented education and upbringing (ensuring the right to freedom of choice of the value position, the possibility of its effective implementation in the presence of a set to overcome disharmony in interaction);

5) the principle of feedback of theoretical training and practical activity, which provides, on the one hand, the comprehension and application of theoretical knowledge in everyday activities, and, on the other hand, - consolidation of empirical knowledge obtained during the study of theoretical disciplines;

6) sequentiality - the gradual learning of all structural components of the spiritual values of the personality, alternate mastery of the skills of responsibility, tolerance, mercy, dignity and self-esteem;

7) continuity - the interconnection of all types of practice, when learning something new is carried out on the basis of experience gained by students in the previous stages of practical training;

8) dynamism - a gradual complication of tasks of various types of educational activities, expansion of the spectrum of tasks for the development of an individual style of formation of spiritual values of students.

Principles of pedagogical support should be implemented in the process of all types of activities and include: conducting explanatory work with students on the formation of spiritual values in them, analysis of the main false judgments about such a phenomenon; formation of a positive set of students for spiritual development; assistance to future specialists during the preparation of an individual plan for the formation of spiritual values; diagnostics of the formation of students' spiritual values by developed indicators, familiarization of students with the results of diagnosis and consulting on the improvement of the level of formation of spiritual values.

It is necessary to develop a prompt card for the student, which would contain 
a description of the process of formation of spiritual values, content, criteria for the formation of such a phenomenon, and advice on improving the effectiveness of the formation of spiritual values. It is advisable to use training exercises, various types of techniques that provide feedback at the discussion stage: description of feelings and emotions in the process of playing a role, discussion of memories about one's life experience, associated with a similar situation or problem, self-observation from the side; conducting with the students various test methods for the identification of individual-typological features, professionally significant and personality traits. Such techniques are aimed at developing spiritual skills, empathy, positive "I-concept" of a future specialist; provide self-assessment by students of their own verbal and nonverbal communication, image, conflict, identification of barriers in interaction. On the basis of the results of these methodological diagnostics it is necessary to give the student recommendations on self-education.

In order to provide pedagogical support and constant feedback with students, it is expedient to develop a training program for further self-development, self-education, and the formation of spiritual values. The developed training program is focused primarily on the organization of interaction between the teacher and students. It is based on the idea of constructivist pedagogy, which seeks to create a developing environment for students, which provides the possibility of searching for their own "I", learning ways to construct knowledge, taking into account the individuality and uniqueness of the experience of each personality (Zhyrun, 2011).

The training program "Self-creation" contains the following blocks: student's prompt cards, methodical tools, diagnostic tools, situations and video situations of actions of responsibility, tolerance, mercy, dignity, self-sufficiency, exercises to identify spiritual values of personality in everyday life.

Pedagogical support of students in the educational process of a higher education institution involves prompt assistance in solving their individual problems in the realization and formation of spiritual values, in the development of creative potential of students.

Pedagogical support is a moral category, since it is about the assistance to the 
developing person, about the self-determination and self-realization, the formation of relations with people. Pedagogical support is valuable if it is tactful, competent, timely, targeted, dosed and everyday, and most importantly - if in all cases it fully fulfills its educational purpose and works for the future.

We propose a model of pedagogical support developed in our research as a valueoriented strategy for the formation of students' spiritual values. At the first stage, students' attention should be emphasized on the identification of actions of responsibility, tolerance, mercy, dignity in relationships, which requires comprehension. The identification of spiritual values is based on the analysis of various cultural values: the values of art, everyday culture of the relationships of students with groupmates, coursemates, friends.

The second stage of pedagogical support is related to the students' search for their own understanding of spiritual values. At this stage, the attention must be focused on their orientation towards humanistic values and the formation of students' spirituality.

The third stage is a dialog, aimed at creating students' own algorithm for identifying spiritual values in a relationship. Entering into ideas of Grygoriev, who researched the influence of pedagogical support on the students' search for value-based sense of life, we believe that the important condition for the formation of spiritual values in students is the position of a teacher who can understand, accept and recognize. At this stage, students create their own algorithm for identifying spiritual values, comparing it with the views of friends, comrades, groupmates, and close people.

The fourth stage is reflexive, related to the analysis of joint activities to solve moral problems in identifying spiritual values in relationships. The necessity of this stage is due to incomplete dialogue, readiness of students to exchange spiritual values. The role of the teacher at this stage is to provide students with opportunities for selfdetermination in relation to spiritual values.

Thus, the process of forming the spiritual values of student youth in a higher education institution involves self-knowledge, self-awareness, disclosure by young boys and girls of their personal characteristics. All this is decisive in interaction, communication with other people, in the consideration of the main components of the 


\section{PEDAGOGY IN MODERN CONDITIONS}

spiritual values of the personality, in teaching students constructive relationships, techniques of self-regulation of emotions and behavior. 


\subsection{Distant education: prospective and pitfalls when studying English as a foreign language}

Due to the development of international cooperation, the problem of providing educational opportunities for students of non-philological universities is especially relevant today, which leads to interest in the development of distance learning courses of English as a foreign language. Such courses facilitate access to speech information, materials on the geography of England and the United States and increase interest directly in language and culture.

Another reason, that makes this study relevant is the pandemic of COVID-19 which triggered the study precipitation as no way in terms of pandemic was possible to realize the process of education.

Let us recall that the English language is the national language, the expression and custodian of the mentality of english people, their spiritual culture. Compared to other languages of the world, English is rich in vocabulary, phraseology, sound and grammar systems and other language systems. But most fascinating is the harmony of the British English language, its phonetic structure. First of all, languages differ in phonetics. Accordingly, this is due to the fact that linguistic transmission of information is the main form of existence of language. Each language has its own unique sound system, reflecting the conceptual gaps of a particular linguistic culture, and thus represents a significant difficulty in learning a foreign language. The study of phonetics and phonology should contribute to the formation of skills of literate speech in nonphilological students at a low A1 level (Vantage), because the purpose of language learning, as we know, is the implementation of oral communication.

Soviet researcher M.N. Shutova calls a number of communicative strategies for studying phonetics by foreign students, among which are:

- Awareness of the phonetic features of the phonetic system of AYA;

- Assimilation of the sound organization of the British speech, features of its sound system; 
PEDAGOGY IN MODERN CONDITIONS

- Development of the ability to speak and read, observing a cluster of orthoepic norms;

- Formation of the ability to observe the correct pronunciation;

- Formation of a conscious attitude to the work of speech organs;

- Education of aspiration to skillful and the most correct use of phonetic means of the English language

The phonetic features of modern English include:

In English, there are 32 consonant phonemes, which differ in the way of creation, in the place of creation with the participation of voice and noise and 6 vowels, which are divided according to the level of language uplift and their number.

Vowels and consonants can be in a strong or weak position. A weak position can implement a combinatorial, positional, or optional feature of the phoneme.

English is in tune.

English often does not avoid the coincidence of vowels and difficult to pronounce the confluence of consonants.

Use of an apostrophe.

English has multi-stage, comparable to Chinese and Vietnamese, intonation system: speech melody, speech tempo, speech intensity, speech rhythm and the use of phrasal, logical or emphatic stress.

Training in the phonetic structure of the language takes place primarily during the initial stage of training at the preparatory faculty. In this case, the effectiveness of teaching phonetics at the initial stage is determined by a number of factors: methodological support, number of classes, individualization of training and the like. In many cases, difficulties arise at this time, which can be caused by a short period of study, which prevents some students from fully mastering the material; a small number of classroom classes, due to which there is an intensification of the educational process, negatively affects the formation of auditory skills; specific multinational composition of groups; features of group occupancy during the academic semester. Thus, students who do not have full phonetics start learning at the main stage. If theoretically the main purpose of teaching phonetics at the main stage is to overcome the emphasis and 
improve listening skills, bringing them to the level of skills for use in any speech situations, then in practice the teacher is forced to work out the introductory course. All the above is the reason for the need to develop a remote accompanying course in phonetics, in which foreign students had the opportunity to supplement, expand and systematize knowledge of the phonetics of the language, train speaking and reading skills and bring to pronunciation skills. Such a course can be used both during independent work of students after passing the introductory phonetic course, and during classroom work with students. Thus, the "New Dictionary of Methodological Terms" defines the accompanying course of phonetics as a course of mastering auditory skills of a foreign language, is not allocated to a separate aspect of learning and is conducted in parallel with mastering speech activities and lexical and grammatical material. The task of the accompanying phonetic course is to improve and automate auditory skills. Remote accompanying course of phonetics aims to provide additional opportunities for studying phonetics, developing the ability to independently control the correctness of articulation, development of phonemic hearing, automation of spoken skills, rhythms and intonation, improving reading and speaking skills, i.e. gives the opportunity to improve pronunciation takes extra classroom time.

In general, the use of distance learning technology makes it possible to expand learning opportunities according to many criteria: it becomes possible to organize training simultaneously for students of different profiles, specializations and directions; increases the professionalism and competence of students through the use of information at home; a unified information space is being formed; there is an opportunity to study without interrupting the work process (for working students); the cost of material resources is reduced. The choice of modern teaching aids must be approached very thoroughly, since this is an important point in teaching. The use of pedagogical technologies in work aimed at solving certain didactic problems. Therefore, it is necessary to reasonably and creatively evaluate the possibilities of a specific teaching technology, know the pros and cons, and know where it is best to apply. Along with the advantages that distance learning provides, there are also disadvantages. Of course, this is: the absence of the teacher's physical presence in the 


\section{PEDAGOGY IN MODERN CONDITIONS}

classroom. Which affects the students' perception of the material, since a number of psychological factors are triggered, because a teacher is not only a source of information, and not only a provider of discipline and work in class, but also, first of all, it is an authority and a psychologist who finds an approach to each student, because the perception of each person is different and the same explanation that works for one person may be absolutely futile for another. Thus, when transferring students to distance learning, a certain kind of discrimination arises, since at a distance the teacher cannot see either the eyes or the students' reactions to WHAT the teacher says and HOW it is said, respectively, and part of the control over the situation is lost. Especially it is felt when learning languages and when it comes to phonetics. 


\subsection{Theoretical and methodological principles of professional training of specialists in physical therapy and occupational therapy in higher education institutions of the European Union}

The domestic system of higher education is in a transitional stage of development, which is characterized by the processes of finding and approving new approaches to learning, which are designed to best meet the needs of reforming Ukrainian society. This is due to the integration of the domestic higher education system into a single European educational space. From today's standpoint, the change of educational paradigms at the turn of the century and the transition from reproductive-pedagogical civilization to creative-pedagogical civilization is associated with a change in human development, where the priority is the formation of a holistic, harmonious and free personality [19-21]. This process requires involving society in fundamental cultural values, including health values. The situation in Ukraine, as in most countries of the world, is characterized by a progressive decline in the public health of the nation as an integrative indicator of physical and mental health of citizens. The urgency of the problem of training specialists in physical therapy and occupational therapy is determined by the need for further development of health education in order to strengthen the health of the population of Ukraine [22-27].

The research aim is to determine the theoretical and methodological principles of professional training of specialists in physical therapy and occupational therapy in higher education institutions of the European Union.

As a result of the analysis of the scientific literature, it is concluded that the number of studies related to the study of foreign experience in the training of specialists in physical therapy is limited in domestic science. Domestic scientists (N.Belikova, A. Hertsyk, S. Hook, R. Karpyuk, Yu. Lyannoy, etc.) [19,22] fragmentarily studied the main aspects of professional training in the field of health care in economically developed countries, among such aspects - and training of specialists in physical therapy, occupational therapy. In particular, A. Hertsyk's dissertation (2006) clarifies the organizational and methodological aspects of training bachelors of physical rehabilitation in Canada. The monograph of R. Karpyuk (2010) describes the features 
of professional training of specialists in adaptive physical culture in the leading countries of Europe and the United States. N. Belikova's dissertation (2012) substantiates the main trends in the training of specialists in physical rehabilitation in the Russian Federation, describes the experience of North America and Australia, Great Britain and some European countries. In the dissertation of S. Hook (2015) the peculiarities of professional training of specialists in physical rehabilitation in the universities of Great Britain are thoroughly investigated. The monograph by Yu.Lyannoy (2016) outlines some aspects of professional training of future specialists in physical rehabilitation with a master's degree in the Baltic States, Austria, the Netherlands, the United States and Canada.

A comparative analysis of the structure and content of bachelor's degree in physical therapy from leading universities in European countries (Greece, Spain, Italy, Norway, Sweden, Finland and Ukraine) allowed us to record the presence of common and distinctive features and approaches. Common features include the following: introduction of step-by-step education systems; application of credit-transfer system of education. There is some difference in the structure of curricula [19-22,27]. Thus, the curriculum for bachelors of physical therapy in most European universities provides 3 or 3.5 years of study (except for Greece, where 4 years are planned), while the vast majority of Ukrainian higher education institutions - 4 years of study. The content of the analyzed curricula of Norwegian universities consists of three or four large courses of 10 to 40 ECTS credits for each academic year. At the same time, in the curriculum of the Ukrainian university there are much more of them - eight for each of the four courses, they are relatively smaller in volume - on average 4-5 ECTS credits each. In addition, there was a difference in the amount of workload. In European higher education institutions, this amount is a total of 180 - 240 ECTS credits, in contrast to 240 ECTS credits in domestic higher education. In the process of characterization of professional training of physical therapy specialists in European higher education institutions, attention is focused on the significant predominance in terms of workload planned for practical clinical experience: in Norwegian universities - 45 ECTS credits, in Spanish universities - 42 ECTS credits, in Swedish universities - 37 ECTS credits, 
PEDAGOGY IN MODERN CONDITIONS

in Italian - 63 ECTS credits, but it is recognized that the researchers did not pay close attention to the study of foreign experience in the training of physical therapy specialists in Asian countries [23-26].

As established in a preliminary analysis of the literature, physical therapy and occupational therapy as a way to restore human health and functionality, began to take shape in Ukraine and the European Union relatively recently - at the end of last century and therefore is still in its infancy [19-27]. The relevance and timeliness of the formation of this area as an independent educational component is indicated not only by its deep roots in alternative medicine, various systems of physical education, but also intensive development in many countries, where people are considered a core value of society, forming a demand for highly qualified physiotherapists and occupational therapists, rehabilitation centers appear, where under the supervision of specialists the health of patients is restored after injuries due to exhaustion of physical and moral health, psychological disorders, etc.

When studying medical-biological and social-psychological sciences, a specialist in physical therapy and occupational therapy must have in-depth knowledge of the means and methods of restoring partially or completely lost body functions, etc. simultaneously combine a biologist, physician, psychologist and teacher (Fig. 1). Training of specialists in physical therapy and occupational therapy is a problem of national importance for every civilized country. The latter follows from the very interpretation of the concept of «Physical Therapy and Occupational Therapy» as a process of restoring partially or completely lost functions of the human body by means of non-drug correction, the main of which is the impact on the motor sphere [19].

Thus, the relevance of proper training of a highly qualified specialist in physical therapy and occupational therapy is justified by the wide range of populations with which he will have to work. 
PEDAGOGY IN MODERN CONDITIONS

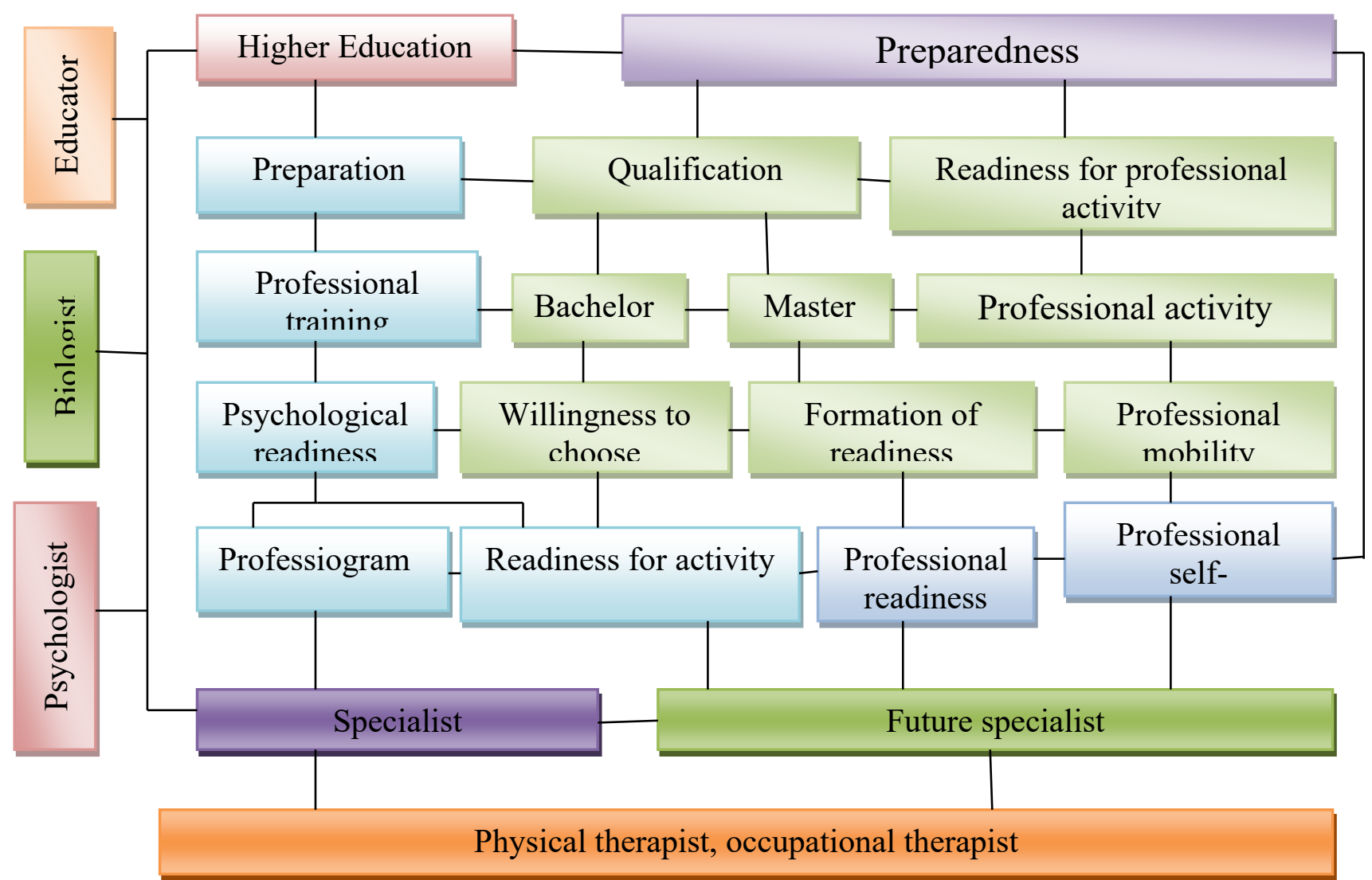

Fig. 1. Generalized scheme of training specialists in physical therapy, occupational therapy.

Due to its versatility, the profession of physical therapist and occupational therapist should be used to preserve and strengthen the health of the population, which is one of the key problems in society. Scientific studies evaluating the effectiveness of the use of rehabilitation methods have shown that a properly designed rehabilitation program can return to active life more than $50 \%$ of patients. After all, the health of society is an indicator of the civilization of the state, which reflects the level of its socio-economic development, the main criterion of expediency and efficiency of all spheres of human activity. 


\section{5 Методологічні основи дослідження сімейної форми здобуття освіти}

В умовах сімейної форми здобуття освіти сім'я працює як єдиний організм, де iï члени об'єднані спільними інтересами і справами. Аналіз літературних джерел дозволив виявити, що сьогодні існує ототожнення сімейної та домашньої освіти (хоумскулінгу). Отже, слід зосередитися на різниці між цими поняттями. У країнах Західної Європи та США широко поширене домашнє навчання (хоумскулінг). Термінами homeschooling (home school, home education або home learning) називають навчання дітей вдома, здебільшого силами батьків.

Проаналізувавши низку наукових праць (табл. 1), ми прийшли до висновку, що попри таку величезну актуальність домашньої освіти, в науковій літературі ця тема досліджена недостатньо; набагато більше існує публікацій у популярних 3МІ та літератури у стилі non-fiction.

Таблиця 1.

Альтернативні підходи до визначення поняття «домашня освіта»

\begin{tabular}{|c|c|}
\hline Джерело & Сутність поняття \\
\hline $\begin{array}{l}\text { Бартосік } \Pi . \\
{[28]}\end{array}$ & $\begin{array}{l}\text { заходи, що проводяться в домашньому середовищі поза шкільними установами, за } \\
\text { допомогою вільно обраних методів, засобів і технологій і включає: обов’язок батьків } \\
\text { виховувати та навчати своїх дітей; навчання, для якого головною базою є родинний } \\
\text { будинок і яке відбувається під наглядом батьків; план навчання, який можна } \\
\text { застосувати згідно } 3 \text { потребами та відповідною ситуацією; навчання у домашньому } \\
\text { середовищі замість шкільного класу; участь родини в житті місцевої спільноти; } \\
\text { користування загальнодоступними дидактичними посібниками }\end{array}$ \\
\hline Вікіп & $\begin{array}{l}\text { ввчання дитини у домашніх умовах без відвідування загальноосвітньої школи або } \\
\text { вчання у домашній школі }\end{array}$ \\
\hline $\begin{array}{l}\text { Вихрист } \\
\text { Ж. [30] }\end{array}$ & $\begin{array}{l}\text { практика навчання та виховання поза навчальними закладами, у процесі якої батьки } \\
\text { разом } з \text { дітьми здійснюють освітню діяльність, яка відповідає потребам сім’ї і дітей; } \\
\text { освітній підхід, який передбачає вибір батьками (з урахуванням прав і думки дітей) } \\
\text { педагогічних підходів, методів і форм навчальної діяльності, темпу навчання, освітніх } \\
\text { ресурсів, що забезпечують індивідуалізацію та гнучкість навчання }\end{array}$ \\
\hline $\begin{array}{l}\text { Гонч } \\
\text { С. }[3\end{array}$ & $\because$. \\
\hline $\begin{array}{l}\text { Енциклопеди } \\
\text { чний словник } \\
\text { Вебстера [32] }\end{array}$ & $\begin{array}{l}\text { 1 вдома, яка базується на незалежних проектах певних } \\
\text { луючись про своїх дітей, беруть на себе повну } \\
\text { у, виховання і соціалізацію } \\
\text {. }\end{array}$ \\
\hline $\begin{array}{l}\text { Єльникова О. } \\
{[33]}\end{array}$ & $\begin{array}{l}\text { спосіб здобуття освіти, шляхом навчання дитини в домашніх умовах, без відвідування } \\
\text { загальноосвітньої школи, або навчання в різного виду домашніх школах. Отримання } \\
\text { атестату відбувається на підставі зданих екзаменів за визначеним державою базовим } \\
\text { стандартом }\end{array}$ \\
\hline
\end{tabular}


Продовження таблиці 1

\begin{tabular}{|c|c|}
\hline Дже & \\
\hline $\begin{array}{l}\text { Загітова } \\
{[34]}\end{array}$ & $\begin{array}{l}\text { вчання за медичними показаннями, коли дитина не може відвідувати ш } \\
\text { аном здоров'я, оформлюється медичний висновок, і до дитини приходять в } \\
\text { сіх предметів шкільної програми, при цьому навчання відбувається у відпо } \\
\text { шкільної програми }\end{array}$ \\
\hline 5] & $\begin{array}{l}\text { собливий соціальний інститут освіти, який існував i iснує пара } \\
\text { ституціональними (державними, суспільними та ін.) формами освіти }\end{array}$ \\
\hline
\end{tabular}

Джерело: систематизовано автором

Згідно з Законом України «Про освіту» основними формами здобуття освіти є: 1) інституційна (очна (денна, вечірня), заочна, дистанційна, мережева); 2) індивідуальна (екстернатна, сімейна (домашня), педагогічний патронаж, на робочому місці (на виробництві); 3 ) дуальна. При цьому сімейною (домашньою) формою здобуття освіти є спосіб організації освітнього процесу дітей самостійно їхніми батьками для здобуття формальної (дошкільної, повної загальної середньої) та/або неформальної освіти. Відповідальність за здобуття освіти дітьми на рівні не нижче стандартів освіти несуть батьки [36]. Оцінювання результатів навчання та присудження освітніх кваліфікацій здійснюються відповідно до законодавства. Оскільки українське законодавство ототожнює ці дві форми здобуття освіти, необхідно проаналізувати погляди вчених і зробити аналіз альтернативних підходів до визначення поняття «сімейна освіта» (табл. 2).

Таблиця 2.

Альтернативні підходи до визначення поняття «сімейна освіта»

\begin{tabular}{|c|c|}
\hline Джерело & Визначення \\
\hline Антуф'єва М. [37] & $\begin{array}{l}\text { форма освіти поза освітніми закладами, що організується і здійснюється } \\
\text { силами батьків і надає право на проходження проміжних атестацій у формі } \\
\text { екстерната в обраному закладі освіти }\end{array}$ \\
\hline $\begin{array}{l}\text { Декларація } \\
\text { Берлинської } \\
\text { конференції [38] }\end{array}$ & $\begin{array}{l}\text { практика, за якої батьки і діти самі здійснюють освітню діяльність, } \\
\text { забезпечуючи навчання, що відповідає потребам сім'ї та дітей }\end{array}$ \\
\hline $\begin{array}{l}\text { Енциклопедичний } \\
\text { словник Брокгауза } \\
\text { Ф.А., Ефрона I.A. } \\
\text { [39] }\end{array}$ & $\begin{array}{l}\text { цілеспрямований процес отримання освіти в сім'ї, що організовується та } \\
\text { здійснюється батьками відповідно державним освітнім стандартам, } 3 \\
\text { періодичною атестацією за результатами навчання }\end{array}$ \\
\hline Загітова А. [34] & $\begin{array}{l}\text { навчання, при якому уроки проводять батьки або рідні, самостійно обираючи } \\
\text { матеріали і розклад навчання дитини, при цьому дитина залишається офіційно } \\
\text { прикріпленою до школи, проходе щорічну атестацію і складає іспити, таким } \\
\text { чином контролюєтья відповідність обсягу знань дитини вимогам шкільної } \\
\text { програми }\end{array}$ \\
\hline $\begin{array}{l}\text { Кощієнко } \text { I.В., } \\
\text { Покровська Л. I. } \\
{[40]}\end{array}$ & $\begin{array}{l}\text { варіативна форма навчання дитини, що базується на бажанні батьків (законних } \\
\text { представників) надати своїй дитині освіту в сім'ї }\end{array}$ \\
\hline
\end{tabular}


Продовження таблиці 2

\begin{tabular}{|l|l|}
\hline \multicolumn{1}{|c|}{ Джерело } & \multicolumn{1}{|c|}{ Визначення } \\
\hline $\begin{array}{l}\text { Стародубцева I. } \\
\text { [41] }\end{array}$ & $\begin{array}{l}\text { Педагогічна допомога у формуванні цілісного, об'єктивного погляду на події, що } \\
\text { відбуваються з дитиною, у засвоєнні методів ефективної регуляції поведінки дітей } \\
\text { і демократичних форм спілкування }\end{array}$ \\
\hline Якуніна А. [42] & $\begin{array}{l}\text { Цілісна форма суб'єктно-орієнтованої гуманістичної освіти, що дозволяє у значній } \\
\text { мірі розкрити позитивні суб’єктні якості учнів в умовах реалізації індивідуальних } \\
\text { освітніх траєкорій, що базується на особистісно-орієнтованому підході у } \\
\text { навчанні і вихованні, а також на принципах гуманізації та індивідуалізації } \\
\text { освітнього процесу, що спивається на формування і розвиток таких властивостей } \\
\text { особистості учня сімейної школи, як високий рівень навченості, вихованості, } \\
\text { соціалізації, незалежність мислення, прагнення до неперервної самоосвіти і } \\
\text { самовдосконаленню }\end{array}$ \\
\hline
\end{tabular}
Джерело: систематизовано автором

Аналіз свідчить, що деякі науковці ототожнюють домашню освіту та педагогічний патронаж. Крім того, якщо досліджувати досвід зарубіжних країн у цьому контексті, маємо визнати, що у деяких країнах дозволене домашнє навчання за медичними показаннями, але дефініція «сімейна освіта» або «сімейна форма здобуття освіти» чи «сімейне навчання» не розглядається у законодавчо-нормативному полі. На наш погляд, поняття «сімейна освіта» $є$ все ж таки ширшим, ніж «домашня освіта». У будь-якому випадку, така освіта передбачає навчання поза школою. У випадку домашньої освіти навчання відбувається вдома за допомогою батьків або членів сімей учнів. За сімейної освіти навчання, виховання і розвиток дитини може відбуватися як вдома (тоді ці поняття тотожні), так і в сімейних та альтернативних школах (у цьому випадку поняття «сімейна освіта» $є$ більш широким). На думку різних учених, існують наступні умови для навчання дитини вдома (табл. 3).

Таблиця 3. Причини (фактори) навчання дітей вдома

\begin{tabular}{|c|c|}
\hline Джерело & Причина \\
\hline $\begin{array}{l}\text { Антуф'єва М. } \\
{[37]}\end{array}$ & $\begin{array}{l}\text { релігійні; причини, пов’язані з фізіологічними та психічними особливостями } \\
\text { дітей, заняття професійним спортом та різними видами мистецтва; ранній } \\
\text { інтелектуальний розвиток, проблеми } 3 \text { адаптацією і взаємодією дитини } 3 \\
\text { дитячим колективом; втрата мотивації до навчання; незадоволення батьків } \\
\text { якістю та організацією шкільної освіти; проживання сім’’̈ в іншій країні і } \\
\text { бажання отримати атестат на Батьківщині }\end{array}$ \\
\hline Брайан $\mathrm{F}$ & $\begin{array}{l}\text { зацікавленість батьків у вихованні дітей; навчання дітей під пильним наглядом } \\
\text { батьків; наявність програми, яка сприяє індивідуалізації дитини; навчання } \\
\text { дитини у родинному оточенні; участь сім'ї у громадській роботі }\end{array}$ \\
\hline
\end{tabular}


Продовження таблиці 3

\begin{tabular}{|l|l|}
\hline \multicolumn{1}{|c|}{ Джерело } & \multicolumn{1}{|c|}{ Причина } \\
\hline Загітова А. [34] & $\begin{array}{l}\text { батьки часто переїжджають з одного місця в інше, при цьому дитина не в змозі } \\
\text { щорічно змінювати школу і адаптуватися до нового колектиу учнів та вчителів; } \\
\text { дитина має важливі захоплення (наприклад, професійні заняття спортом чи } \\
\text { музикою), що віднімає багато часу і потребує постійних від'їздів на конкурси і } \\
\text { змагання; значне випередження дитиною своїх однолітків у розумовому } \\
\text { розвитку, завдяки чому дитина нудьгує на уроках і втрачає мотивацію до } \\
\text { навчання }\end{array}$ \\
\hline $\begin{array}{l}\text { Кощієнко I., } \\
\text { Покровська Л. } \\
\text { [40] }\end{array}$ & $\begin{array}{l}\text { Розвиток дистанційного навчання, прямо пов'язане з прогресуючим розвитком } \\
\text { інформаційних технологій }\end{array}$ \\
\hline Рубан Л. [44] & $\begin{array}{l}\text { Для дітей у віддалених населених пунктах, де є транспортні труднощі; для дітей, } \\
\text { які не можуть навчатися у загальноосвітній школі - діти з особливими } \\
\text { потребами, діти індиго }\end{array}$ \\
\hline $\begin{array}{l}\text { Sетеупое.сот } \\
\text { [45] }\end{array}$ & $\begin{array}{l}\text { В залежності від потреб сім'ї: навчатися паралельно з батьками; більше часу } \\
\text { проводити з сім’єю; постійно подорожувати; укріпити сімейні зв'язки та } \\
\text { розділяти сімейні цінності; залежно від релігійних поглядів: святкувати сімейні } \\
\text { заходи, паломництво; залежно від потреб дітей: більше часу на свіжому повітрі; } \\
\text { зручний графік занять; самостійне планування навчального навантаження; } \\
\text { індивідуальний темп засвоєння матеріалу; більше часу на хобі; для особливих } \\
\text { дітей; в залежності від освітного процесу: індивідуальний підхід; } \\
\text { незадоволення освітнім і соціальним середовищем в школі; фокус на отриманні } \\
\text { знань, а не вивченні фактів; можливість корегувати освітні програми }\end{array}$ \\
\hline Уникнення негативного впливу сучасної системи шкільної освіти \\
\hline Стівенс М. [46]
\end{tabular}
Джерело: систематизовано автором

Професор Бостонського університету Пітер Грей наводить результати опитування батьків, які обрали домашне навчання для своїх дітей [48]. Так, усього опитано 231 сім’ї, в яких навчається вдома 521 дитина. 3 них: канадські сім'ї - 19, американські - 186, з європейських країн - 26. У результаті опитування отримано наступні причини: підвищення відповідальності самої дитини $(18,8 \%)$, виховання вміння планувати свій власний час і ставити свою мету (18,8 \%), освітній процес є природнім та інтегрованим у життя (18,7\%), батьки самі визначають освітню траєкторію і пріоритети навчання $(18,6$ \%), вдома більш насичене навчальне середовище, яке має дуже багато джерел (18,5 \%), вдома діти мають більше можливостей отримати те, що насправді хочуть (6,5%).

Національний центр статистики у сфері освіти (NCES) CША провів опитування й виявив причини, які спонукають батьків навчати дітей удома. Так, 
батьки схиляються до домашнього навчання 3 декількох причин: половина опитаних батьків вважає, що вони особисто відповідальні за навчання дітей і можуть дати їм кращу освіту, навчаючи їх удома; 40 \% батьків навчає дітей удома з релігійних міркувань; більше чверті батьків віддає перевагу домашньому навчанню, оскільки

хоче застерегти дітей від негативного впливу шкільного оточення; 5\% батьків схильні до домашнього навчання за сімейними обставинами; по 1\% опитаних батьків підтримують домашнє навчання з таких причин: інвалідність дитини, затримка в розвитку дитини, транспортні труднощі, особливості професійної діяльності батьків [49].

Крім того, такими причинами можуть бути ритм професійного життя батьків - відрядження, переїзди, отже, потрібна така собі «мобільна школа»; також батьки можуть належати до певної культури дауншифтерів. У багатодітних сім’ях сімейна освіта також може бути тимчасовим заходом. Отже, на наш погляд, всі причини переходу на сімейну форму здобуття освіти можна класифікувати за двома ознаками: 1) За ініціативою батьків (драйвер «батьки»): незадоволення якістю та організацією шкільної освіти, релігійні, проживання сім’ї в іншій країні і бажання отримати атестат на Батьківщині, зацікавленість у вихованні дітей, індивідуалізація навчання у родинному оточенні, часті переїзди, постійні подорожі. 2) За ініціативою дітей (драйвер «діти»): фізіологічні та психологічні особливості, проблеми з адаптацією, втрата мотивації до навчання, повільний темп засвоєння інформації, професійні заняття, значне випередження дитиною своїх однолітків.

За сімейної форми здобуття освіти батьки можуть максимально враховувати індивідуальні особливості дитини, батьки разом з дитиною можуть корегувати програму і режим занять, час на відпочинок. Крім того, діти-хоумскулери зазвичай достатньо багато подорожують з рідними, часто пристосовуються до змін, якщо сім'я часто змінює місце проживання. Якщо дитина професійно займається спортом, домашнє навчання також є вдалою ідеєю, адже режим сімейного навчання пристосований для поїздок на змагання, турніри і виступи. 
За умов такого навчання учень вивчає саме ту галузь, яка для нього цікава, що дозволяє простіше виявити здатності і таланти, а також найкращим чином розкрити потенціал дитини (мал. 1).

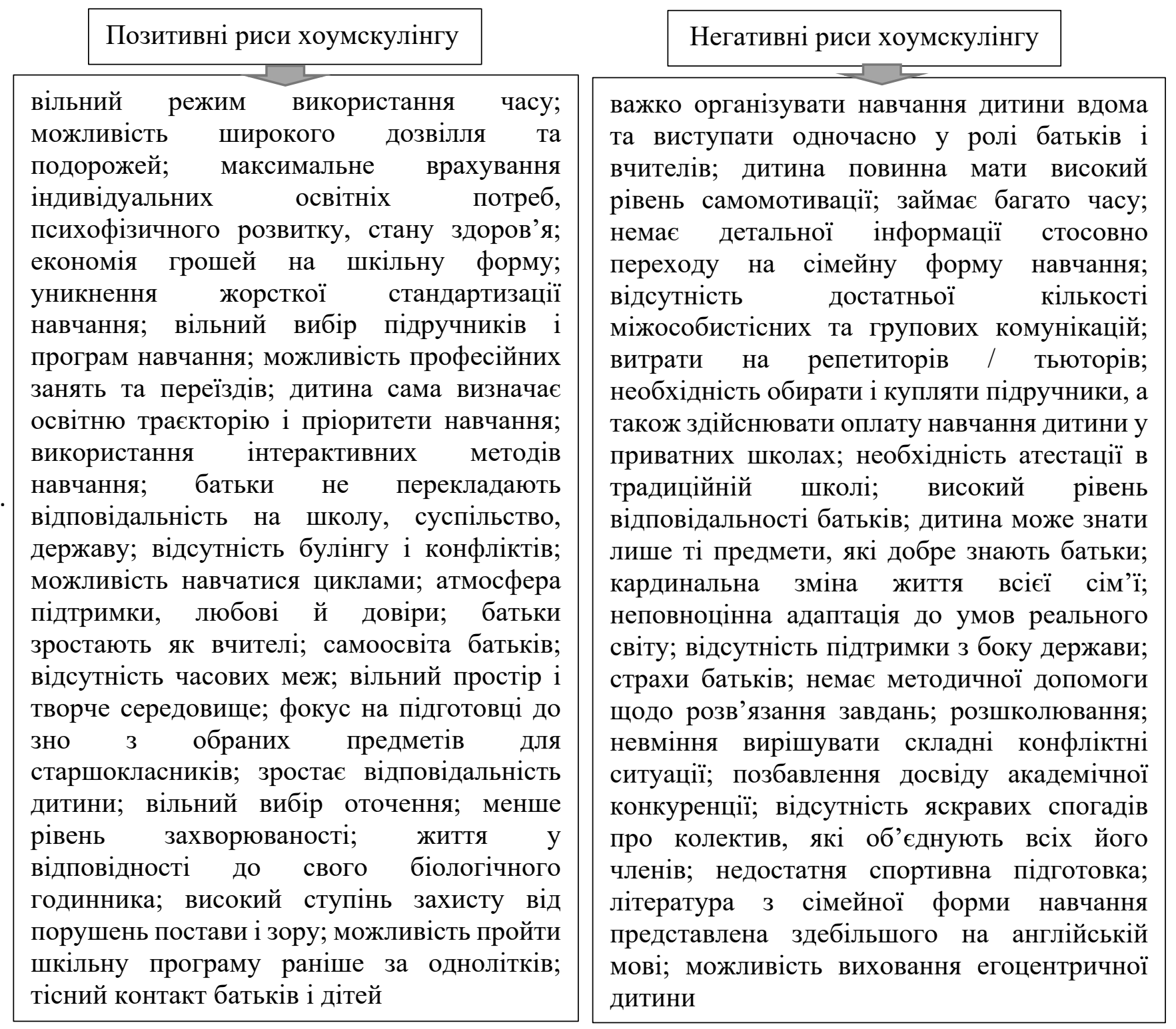

Малюнок 1. Позитивні і негативні риси сімейної форми здобуття освіти (хоумскулінгу) Джерело: розроблено автором

Сімейна освіта укріплює зв'язки між членами родини, оскільки діти більше часу проводять з рідними, і не просто щиро цікавляться справами дитини, але й проживають емоції і враження разом 3 дитиною. Таким чином, можемо 
зазначити, що сімейна форма здобуття освіти має і певні переваги, і недоліки. Не зважаючи на це, ця форма здобуття форми освіти поширюється світом.

Беручи свій початок у маленьких громадах $80-x$, сімейна (домашня освіта) швидко здобула популярність у 90-х роках XX століття і займає особливе місце серед альтернативних освітніх пропозицій. Якщо розглянути досвід домашнього навчання у світі, можна спостерігати наступне: домашня освіта набирає все більшої популярності у США, Канаді, Франції, Росії, Україні. Якщо у 1994 році дітей, які отримували освіту в індивідуальному порядку, в усьому світі було лише 345 тисяч, то в 2001 році - біля мільйона, у 2015 році - практично 5 млн. осіб, наразі експерти говорять про цифру в 10-12 млн. осіб. Статистика свідчить, що кількість «домашніх» дітей стрімко зростає: від 2\% до $8 \%$ на рік за останні декілька років [44]. Натомість, Т. Каменєва зазначає, що моніторинг розповсюдження хоумскулінгу в розвинених країнах демонструє достатньо невисокі показники - кільксть хоумскулерів там не привищує 2-3 \%. Рекордсменом з кількості дітей, які знаходяться на домашньому навчанні є США - за різними даними, в Америці хоумскулерами є від 4 \% до 10 \% всіх школярів. Натомість, у половині країн Євросоюзу, серед яких Німеччина, Нідерланди та Швеція, віддалене навчання дітей заборонене. Виключення можливі лише у виняткових обставинах, а батькам, які порушують приписи загрожує штраф і в деяких випадках навіть в'язниця [50]. М. Ситник зазначає, що навіть у розвинутих країнах, які підтримують домашню освіту, кількість хоумскулерів не перевищує 2-3\% [51].

Цікавий досвід Ірландії в плані регулювання сімейної освіти. У цій країні сформована одна з найбільш цілісних концепцій домашньої освіти на правовому рівні. Так, в країні існує Агенція з питань дітей та сім’і, роль якої полягає у наданні методичної та організаційної допомоги хоумскулерам. Окремий розділ положення про сімейну освіту надає рекомендації стосовно того, як проводити співбесіди із учнями та батьками таким чином, щоб максимально природнім чином отримати необхідні відомості про рівень розвитку дитини, уникнути стресової ситуації для родини. Цікаво, що якщо представник агенції з питань 


\section{PEDAGOGY IN MODERN CONDITIONS}

дітей та сім’ї має сумніви щодо самостійності дитини або иї рівня досягнень, він має право за попередньою домовленістю завітати до родини і навіть бути присутнім під час освітнього процесу. При цьому додатково наголошується, що ніхто не очікує від батьків проведення шкільних уроків для власної дитини. Так, якщо навчання відбувається під час прогулянки, посадова особа може приєднатися до родини.

Враховуючи позитивний досвід хоумскулінгу, слід зазначити, що є велика кількість країн, де хоумскулінг не визначено або заборонено. Для більш детального аналізу доцільно розділити всі країни на 3 кластери відповідно до нормативно-правового забезпечення функціонування сімейної освіти. До першого кластеру віднесемо ті держави, в яких хоумскулінг є дозволеним, до другого - країни з невизначеним статусом хоумскулінгу, до третього - країни, в яких хоумскулінг не є дозволеним (табл.4).

Таблиця 4.

Кластеризація країн за ступенем нормативно-правової дозволеності хоумскулінгу

\begin{tabular}{|c|c|}
\hline Кластер & Країни-учасники \\
\hline $\begin{array}{l}\text { I кластер - } \\
\text { хоумскулінг є } \\
\text { юридично } \\
\text { дозволеним }\end{array}$ & $\begin{array}{l}\text { Австрія, Австралія, Азербайджан, Албанія, Антігуа і Барбуда, Аруба, Багами, } \\
\text { Барбадос, Білорусь, Беліз, Бельгія, Велика Британія, Венесуела, Гана, Гватемала, } \\
\text { Гондурас, Грузія, Данія, Домініканська Республіка, Еквадор, Естонія, Індонезія, } \\
\text { Італія, Ірландія, Ісландія, Канада, Катара, Литва, Малазія, Мексика, Молдова, } \\
\text { Нова Зеландія, Норвегія, ПАР, Перу, Польща, Португалія, Росія, Румунія, } \\
\text { Сальвадор, Сингапур, Словакія, Словенія, США, Тайвань, Тайланд, Трінідад і } \\
\text { Тобаго, Угорщина, Узбекистан, Україна, Філіпіни, Фінляндія, Франція, Чехія, } \\
\text { Чілі, Ямайка }\end{array}$ \\
\hline $\begin{array}{l}\text { II кластер - } \\
\text { невизначений } \\
\text { статус } \\
\text { хоумскулінгу }\end{array}$ & $\begin{array}{l}\text { ина, Болівія, Ботсвана, Гонконг, Єгипет, Індія, Іспанія, Кенія, Колумбія, } \\
\text { Кувейт, Кюрасао, Нідерланди, Нікарагуа, Пакістан, Парагвай, Південна } \\
\text { Уганда, Японія }\end{array}$ \\
\hline $\begin{array}{l}\text { III кластер - } \\
\text { хоумскулінг не } \\
\text { є дозволеним }\end{array}$ & $\begin{array}{l}\text { Болгарія, Бразилія, Бруней, Греція, Ізраїль, Китай, Коста-Ріка, Куба, Латвія, } \\
\text { Мальта, Німеччина, ОАЕ, Панама, Саудівська Аравія, Турція, Уругвай, Хорватія, } \\
\text { Швеція, Швейцарія }\end{array}$ \\
\hline
\end{tabular}
Джерело: складено автором за [52]

Проведений аналіз доводить, що на сьогодні у більшості країн сімейна форма здобуття освіти є дозволеною. Так, аналіз освітніх систем 94 країн дозволив виявити, що у 56 країнах хоумскулінг є дозволений. У 19 - статус не $є$ визначеним, і в 19 - заборонений. У результаті дослідження отримано достатньо 


\section{PEDAGOGY IN MODERN CONDITIONS}

велику частку $-60 \%$ країн з юридичним підгрунтям домашнього навчання, де у випадку конфліктів інтересів батьків і дитини пріоритет надається саме правам дитини. Також слід акцентувати увагу, що в Україні надзвичайно цікавою з точки зору можливостей застосування є ірландська модель сімейної освіти (за умови належної підготовки посадових осіб, які матимуть повноваження на видачу дозволів на сімейну освіту та проведення атестацій). 


\section{6 Визначення теоретико-методичних знань у школярів 8-9-их класів у сфері фізичної культури і спорту}

Знання є провідним компонентом вмісту освіти у фізичному вихованні. Освіта у галуззі фізичної культури повноцінною буде лише тоді, коли учні опанують систему знань, яка характеризується різноманітністю теоретичного матеріалу, що розкриває всі види рухової діяльності [55].

Актуальність полягає в тому, що на сьогодні фізкультурна освіта школярів середніх класів має бути спрямована на формування фізичної культури особи, в якій важливу роль відіграють теоретичні знання. Сьогодні можна стверджувати, що теоретико-методичні знання виступають як провідний компонент навчального предмета «Фізична культура». Проте в практиці фізичного виховання учнів в загальноосвітній школі практично відсутнє формування знань із фізичної культури, що повинно б становити фундаментальну основу загальної середньої освіти $[53,54]$.

На основі інваріативних модулів теоретико-методичних знань представлених в навчальній програмі «Фізичної культура» для 5 - 9 класів нами були розроблені тести для оцінки теоретичних знань учнів з фізичної культури, які включали в себе по 5 питань і були розподілені за наступними розділами: 1 формування здорового способу життя; 2 - про фізичну культуру й спорт; 3 олімпійська освіта та 4 - знання із самоконтролю.

За кожну правильну відповідь учень отримував 1 бал. Максимальна кількість балів - 20, що відповідає 12 балам за 12-бальною шкалою оцінювання навчальних досягнень учнів (табл. 1).

Таблиця 1

Рівень навчальних досягнень 3 предмета «Фізична культура» в учнів 8-их - 9-их класів

\begin{tabular}{|c|c|c|}
\hline $\begin{array}{c}\text { Рівень } \\
\text { навчальних досягнень }\end{array}$ & $\begin{array}{c}\text { Тестові завдання } \\
\text { (бали) }\end{array}$ & $\begin{array}{c}\text { Оцінка за 12- } \\
\text { бальною шкалою }\end{array}$ \\
\hline \multirow{3}{*}{ низький } & 1 & 1 \\
\cline { 2 - 3 } & $2-3$ & 2 \\
\cline { 2 - 3 } & $4-5$ & 3 \\
\hline
\end{tabular}


PEDAGOGY IN MODERN CONDITIONS

\begin{tabular}{|c|c|c|}
\hline \multirow{3}{*}{ середній } & 6 & 4 \\
\cline { 2 - 3 } & $7-8$ & 5 \\
\cline { 2 - 3 } & $9-10$ & 6 \\
\hline \multirow{3}{*}{ достатній } & 11 & 7 \\
\cline { 2 - 3 } & $12-13$ & 8 \\
\hline \multirow{3}{*}{ високий } & $14-15$ & 10 \\
\cline { 2 - 3 } & $16-17$ & 11 \\
\cline { 2 - 3 } & $18-19$ & 12 \\
\hline
\end{tabular}

Особиста гігієна - галузь гігієни, яка розробляє питання збереження та зміцнення здоров’я людини шляхом дотримання раціонального гігієнічного режиму в побуті, особистому житті та трудовій діяльності. До таких питань належать: догляд за шкірою й порожниною рота, гігієнічне утримання житла, одягу, взуття та ін.

Невід’ємним елементом особистої гігієни є раціональна організація режиму праці, відпочинку і розпорядку дня. Розпорядок дня має передбачати правильне чергування пасивного й активного відпочинку зі включенням необхідного обсягу фізичних вправ (зарядка, заняття спортом, прогулянки), загартовуючих процедур (iз використовуванням повітря та води), сну, тривалість якого визначається з урахуванням вікових і індивідуальних особливостей людини та характеру їі роботи.

Особливе значення має раціональне харчування (правильний розподіл споживання їжі протягом доби та їі повноцінність за набором поживних речовин), а також дотримання гігієни статевого життя. Дотримання правил особистої гігієни сприяє зміцненню здоров’я людини i запобіганню різним захворюванням.

Відповідаючи на перше питання з розділу «Теоретико-методичні знання про здоровий спосіб життя», що включає в себе «особиста гігієна», треба було вказати повну відповідь. Пропонувалось обрати відповідь із запропонованих чотирьох: А) догляд за тілом і порожниною рота, відсутність шкідливих звичок; Б) організацію режиму дня, загартування, ранкову гігієнічну гімнастику, догляд за тілом і порожниною рота, заняття фізичними вправами; В) гідро-процедури, 
сон, чергування праці і відпочинку; Г) прогулянки на свіжому повітрі, режим харчування.

За варіант - А) догляд за тілом і порожниною рота, відсутність шкідливих звичок - відповіли 56,1 \% респондентів; за варіант - Б) організацію режиму дня, загартування, ранкову гігієнічну гімнастику, догляд за тілом і порожниною рота, заняття фізичними вправами - 39,6 \%; за варіант - В) гідро-процедури, сон, чергування праці і відпочинку - 3,3%; за варіант - Г) прогулянки на свіжому повітрі, режим харчування - 1,0\%.

Загартування - це поступова адаптація організму до умов навколишнього середовища, які постійно змінюються. Процедури не лише зміцнюють імунітет, а й позитивно діють на нервову систему, покращують обмін речовин та кровообіг, збільшують силу м’язів, надають тонусу, нормалізують артеріальний тиск.

Ми запропонували школярам вказати найефективніший принцип загартування. При цьому запропонували наступні варіанти: А) систематичність; Б) однобічність; В) безконтрольність; Г) нерегулярність. Відповіді розподілились наступним чином, 74,3 \% - обрали варіант - A); 9,9 \% - за варіант - Б); 9,9 \% - вказали на варіант - В) і 5,9 \% зупинились на варіанті - Г). Приємним залишається той факт, що 74,3 \% респондентів 8 - 9 класів знають найефективніший принцип загартування.

Найкраще одержувати енергію сонця за допомогою сонячних ванн. Завдяки сонячним променям взагалі можливе життя всіх живих істот, і людини в тому числі. Завдяки сонячним променям можна й поліпшити своє здоров’я, i продовжити своє життя. Люди, які уникають сонячних променів, виглядають блідими й нездоровими.

Від природи ми так влаштовані, що бути покритими легкою засмагою для людей цілком природно, шкіра пристосована для перебування на сонці й повинна бути ледве смуглястою. Причина багатьох хвороб у тім, що людина мало буває на сонці. 
PEDAGOGY IN MODERN CONDITIONS

Сонячні промені самі по собі, без усяких додаткових засобів, знищують багато хвороботворних мікроорганізмів. Ніж більше шкіра всмоктує сонячних променів, тим більше в організмі людини накопичується захисних сил, тим більше вона запасає енергії, здатної протистояти хворобам. Сонячні промені вбивають мікроби, знешкоджують їхні отрути, підвищують захисні сили організму. Золотаво-коричневий колір шкіри виникає завдяки підшкірному пігменту, який $є$ особливим біологічним продуктом, покликаним захищати організм.

Під впливом сонячних променів в організмі посилено згоряють жири, поліпшується обмін речовин, знижується рівень цукру в крові, поліпшується якість крові, тому що в крові підвищується гемоглобін. Ультрафіолетові промені сприяють виробленню в організмі вітаміну D і кальцію, що збагачує сполуку крові й дозволяє організму справлятися з усіма хворобами. Легше гоються навіть важкі рани.

На питання анкети: «Коли безпечно приймати сонячні ванни?», було запропоновано наступні варіанти відповідей: А) з 12-00 год. до 16-00 год.; Б) до 11-00 год. і після 16-00 год.; В) з 10-00 год. до 14-00 год.; Г) протягом усього дня. За варіант - А вказали - 9,9\%, варіант - Б - 51,2 \%, варіант - В - 34,7 \% та варіант $\Gamma-4,2 \%$. Це говорить про те, що половина опитаних учнів 51,2 \%, компетентні у запропонованому питанні.

Відповідаючи на питання: «Загартування водою триває:»-А) від 10 секунд до 20 секунд; Б) від 20 секунд до 30 секунд; В) від 30 секунд до 90 секунд; Г) більше 90 секунд. Учні 8 - 9 класів розподілили свої голоси наступним чином: 23,1 \% - варіант - А; 55,3 \% - варіант - Б; 19,0 \% - варіант - В; 2,6 \% - варіант Г. Даний розподіл голосів свідчить про те, що незначна частина школярів 8 - 9их класів, а саме 19,0 \%, правильно обрали відповідь.

На питання анкети: «Загартовуючи процедури доречно починати 3 обливання водою:» - А) гарячою; Б) холодною; В) прохолодною; Г) що дорівнює температурі тіла. 8,2 \% обрали варіант - А) гарячою; 9,9 \% обрали варіант - Б) холодною; 49,5 \% обрали варіант - В) прохолодною; 32,4 \% обрали варіант - Г) 
що дорівнює температурі тіла. Слід відмітити, що найвищий відсоток (49,5%) отримав правильний варіант відповіді (табл. 2).

Таблиця 2

Рівень теоретичних знань з предмету «Фізична культура» в учнів 8 - 9-их класів (n=121), \%

\begin{tabular}{|c|c|c|c|c|}
\hline \multirow{2}{*}{ Розділи } & \multicolumn{4}{|c|}{ Варіанти відповідей } \\
\hline & $\mathbf{A}$ & $\mathbf{5}$ & B & $\Gamma$ \\
\hline \multirow{5}{*}{$\begin{array}{l}\text { 1. Теоретико- } \\
\text { методичні } \\
\text { знання про } \\
\text { здоровий } \\
\text { спосіб життя }\end{array}$} & 56,1 & 39,6 & 3,3 & 1,0 \\
\hline & 74,3 & 9,9 & 9,9 & 5,9 \\
\hline & 9,9 & 51,2 & 34,7 & 4,2 \\
\hline & 23,1 & 55,3 & 19,0 & 2,6 \\
\hline & 8,2 & 9,9 & 49,5 & 32,4 \\
\hline \multirow{5}{*}{$\begin{array}{l}\text { 2. Теоретико- } \\
\text { методичні } \\
\text { знання про } \\
\text { фізичну } \\
\text { культуру й } \\
\text { спорт }\end{array}$} & 36,3 & 35,5 & 23,1 & 5,1 \\
\hline & 44,6 & 4,9 & 48,7 & 1,8 \\
\hline & 29,7 & 19,0 & 39,6 & 11,7 \\
\hline & 22,3 & 16,5 & 33,8 & 27,4 \\
\hline & 76,0 & 7,4 & 7,4 & 9,2 \\
\hline \multirow{5}{*}{$\begin{array}{l}\text { 3. Теоретико- } \\
\text { методичні } \\
\text { знання } 3 \\
\text { Олімпійської } \\
\text { освіти }\end{array}$} & 37,1 & 42,1 & 9,0 & 11,8 \\
\hline & 19,8 & 40,4 & 26,4 & 13,4 \\
\hline & 22,3 & 45,4 & 24,7 & 7,6 \\
\hline & 14,0 & 9,9 & 57,8 & 18,3 \\
\hline & 10,7 & 50,4 & 10,7 & 28,2 \\
\hline \multirow{5}{*}{$\begin{array}{l}\text { 4. Теоретико- } \\
\text { методичні } \\
\text { знання із } \\
\text { самоконтролю }\end{array}$} & 11,5 & 47,1 & 19,0 & 22,4 \\
\hline & 13,2 & 60,3 & 11,5 & 15,0 \\
\hline & 9,9 & 71,9 & 10,7 & 7,5 \\
\hline & 10,7 & 41,3 & 35,5 & 12,5 \\
\hline & 26,4 & 16,5 & 12,3 & 44,8 \\
\hline
\end{tabular}

* Відсоток правильних відповідей відображено жирним шрифтом

На питання анкети: «Що таке фізичні вправи?», ми отримали наступні результати: за варіант - A) такі рухові дії, які спрямовані на формування рухових вмінь і навичок - проголосувало - 36,3 \% опитаних; за варіант - Б) види рухових дій, спрямовані на морфологічні і функціональні перебудови організму, на вирішення виховних і освітніх завдань фізичного виховання - проголосувало $35,5 \%$ респондентів; за варіант - В) багаторазове виконання рухових дій проголосувало - 23,1 \% опитаних і за варіант - Г) види рухових дій, які 
спрямовані на зміну психофізіологічного стану особистості - віддали свої голоси - 5,1 \% респондентів. Таким чином, можна констатувати, що незначна частина підлітків (35,5 \%) знають, що таке фізичні вправи.

Фізична підготовка - це педагогічний процес, спрямований на виховання фізичних якостей $\mathrm{i}$ розвиток функціональних можливостей, що створюють сприятливі умови для забезпечення життєдіяльності людини.

Ми поцікавились у респондентів, що є результатом фізичної підготовки та отримали наступні результати. 44,6 \% - обрали варіант - А) фізичне виховання; 4,9 \% - обрали варіант - Б) розумова працездатність; 48,7 \% - зупинились на варіанті - В) фізична досконалість та 1,8 \% - обрали варіант - Г) психічний стан.

Приємним залишається той факт, що 48,7 \% підлітків змогли обрати правильний варіант відповіді.

Психолог Л. С Виготський ввів поняття сенситивних періодів розвитку. Згідно нього кожний віковий період розвитку дитини сенситивний до певних видів навчання і спирається на психічні функції, що перебувають у процесі визрівання. Також прийнято і таке визначення даного поняття: сенситивний період- це період підвищеної сприйнятливості психічних функцій до зовнішнього впливу, особливо до впливу виховання і навчання.

Ми попросили вказати школярів 8 - 9-их класів, найбільш сприятливий вік для розвитку силових i швидкісно-силових якостей. Респондентам пропонувалось обрати правильну відповідь, на їх думку, серед запропонованих варіантів таких, як: А) старший шкільний вік; Б) молодший шкільний вік; В) середній шкільний вік; Г) дошкільний вік.

Як показало анкетування, за варіант - «А» віддали свої голоси - 29,7 \% опитаних, за варіант - «Б» проголосувало - 19,0 \% респондентів, прихильників варіанту - «В» склало - 39,6 \% школярів та 11,7 \% припав на варіант «Г». 39,6 \% опитаних учнів вказали на правильну відповідь.

Учням ми запропонували назвати засоби, які не розвивають швидкісносилові якості: А) стрибки з місця; Б) стрибки у довжину; В) метання; Г) вправи 3 обтяженням власного тіла. 
Розподіл голосів склався наступним чином: за варіант - «А» було віддано $22,3 \%$, за варіант - «Б» $-16,5 \%$, за варіант $-\langle\mathrm{B} »-33,8 \%$, за варіант $-\langle Г »-$ 27,4 \%. Незначний відсоток опитаних (27,4 \%) правильну дали відповідь.

Організація занять у фізичному виховання займає важливе місце в теорії фізичного виховання, тому, що успішне вирішення завдань фізичного виховання у значній мірі залежить від того як буде організовано навчальний процес. Заняття фізичними вправами проводяться з різним контингентом, в різних умовах та 3 різною спрямованістю.

На питання анкети: «Що не відноситься до форми занять рекреаційної, фізкультурно-оздоровчої та спортивної спрямованості?», пропонувалось обрати 3 наступних варіантів відповідей: А) урок; Б) фізична вправа; В) ранкова гігієнічна гімнастика; Г) вправи у режимі навчального дня (фізкультурні паузи).

76,0 \% - обрали варіант - «А», 7,4 \% - отримав варіант - «Б», 7,4 \% - припав на варіант - «В», 9,2\% - опинився в графі «Г». Тільки 7,4 \% школярів дали правильний варіант відповіді.

Третя частина анкети складалась 3 п'яти питань на визначення рівня теоретико-методичних знань 3 Олімпійської освіти. Діти мали вказати, визначення «олімпізму». Пропонувалось обрати правильну відповідь серед наступних: А) ідеологічна основа спортивної діяльності; Б) система підготовки спортсменів до Олімпійських ігор; В) норма поведінки; Г) філософія життя, яка звеличує та об’єднує в гармонійне ціле якості тіла, волі й розуму.

Варіанти відповідей опитаних школярів розподілились наступним чином: 37,1 \% - обрали відповідь під літерою «А», 42,1 \% - вказали на варіант «Б». По незначному відсотку припав на варіанти «В» $\mathrm{i} « Г » ~(9,0 \%$ та 11,8 \% відповідно). Варто відмітити, що незначна кількість школярів (11,8 \%) знають, що таке «олімпізм».

Відповідаючи на друге питання анкети: «На іграх якої Олімпіади Сергій Бубка здобув олімпійське «золото»?, пропонувалось обрати правильну відповідь із запропонованих: А) 1992 р. (XXV Олімпіада, Барселона); Б) 1988 р. (XXIV 
PEDAGOGY IN MODERN CONDITIONS

Олімпіада, Сеул); В) 1996 р. (XXVI Олімпіада, Атланта); Г) 2000 р. (XXVII Олімпіада, Сідней).

Найвищий відсоток $(40,4$ \%) отримав правильний варіант - «Б». По незначному відсотку припало на інші варіанти $(19,8$ \%, 26,4 \% i 13,4 \% відповідно).

Ми попросили назвати українських олімпійців, удостоєних звання Героя України. Варіанти відповідей: А) Василь Ломаченко (бокс) і Наталія Добринська (легка атлетика); Б) Сергій Бубка (легка атлетика) і Яна Клочкова (плавання); В) Олексій Михайличенко (футбол) і Володимир Кличко (бокс); Г) Юрій Білоног (легка атлетика) і Лілія Подкопаєва (спортивна гімнастика).

45,4 \% голосів отримав правильний варіант - «Б». Всі решта кількість голосів відповіли неправильно (22,3%, 24,7 \% і 7,6 \% відповідно).

Було прохання вкажіть вид спорту, чемпіонами Олімпійських ігор з якого є Володимир Лютий, Олексій Михайличенко, Володимир Татарчук, Вадим Тищенко, Олексій Чередник. Школярам пропонувалось обрати правильну відповідь серед наступних запропонованих: А) гандбол; Б) водне поло; В) футбол; Г) баскетбол.

За варіант - «А» - гандбол - 14,0 \%, за варіант - «Б» - водне поло - 9,9 \%, за варіант - «В» - футбол - 57,8 \% і 18,3 \% припав на варіант - «Г» - баскетбол. Правильний варіант - «В», який обрала більша кількість школярів.

Національний олімпійський комітет України, скорочено НОК України громадська організація, що опікується участю українських спортсменів в Олімпійський іграх, діючи відповідно до положень Олімпійської хартії.

На питання анкети: «Коли відзначають офіційну дату народження Національного олімпійського комітету України?», пропонувалось обрати один варіант серед запропонованих: А) 9 березня 2012 р.; Б) 22 грудня 1990 р.; В) 9 травня 1954 р.; Г) 6 липня 1973 p.

50,4 \% голосів отримав правильний варіант - Б) 22 грудня 1990 р.; по 10,7 \% припав на варіанти - А) 9 березня 2012 р. і В) 9 травня 1954 р. та 28,2 \% отримав варіант - Г) 6 липня 1973 р. Слід відмітити, що половина респондентів 
PEDAGOGY IN MODERN CONDITIONS

(50,4 \%) знають, офіційну дату народження Національного олімпійського комітету України.

Четверта частина анкети передбачала перевірку теоретико-методичних знань із самоконтролю. Обмороження або відмороження ушкодження тканин організму під дією холоду. Нерідко супроводжується нагальним переохолодженням організму, особливо часто уражає такі частини

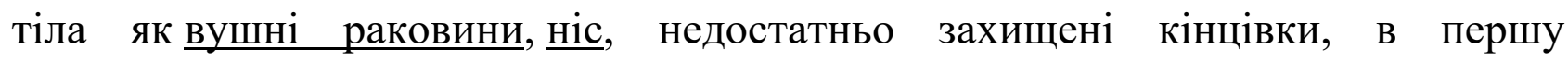
чергу пальці рук та ніг.

Ми попросили дітей вказати, що не відноситься до ознак обмороження. Пропонувалось обрати варіант з наступних запропонованих: А) поколювання; Б) печія; В) збідніння шкіри, втрата чутливості; Г) потовиділення.

Правильно відповіли 22,4 \% підлітків, вказавши варіант - Г) потовиділення. $11,5 \%$ обрали варіант - А) поколювання; 47,1 \% - Б) печія та 19,0 \% - В) збідніння шкіри, втрата чутливості.

Опік - різновид травми тканин тіла, який спричинює дія тепла, електричного струму, хімічних речовин або випромінювання.

Учнів попросили назвати, що не відноситься до ознак опіків. Пропонувалось декілька варіантів відповідей: А) пошкодженням клітин поверхневих шарів епідермісу; Б) з'являється гіперемія; В) з'являється набряк та біль; Г) з'являється поколювання.

За варіант - А) пошкодженням клітин поверхневих шарів епідермісу, було віддано 13,2 \% голосів; за варіант - Б) з'являється гіперемія, було проголосовано 60,3 \%; за варіант - В) з'являється набряк та біль, було віддано - 11,5 \% та за варіант - Г) з'являється поколювання, було проголосовано 15,0%. Слід відмітити, що незначна частина школярів (15,0 \%) правильно впорались із завданням.

Забій, також забиття - пошкодження тканин без порушення їх цілісності. Виникає внаслідок удару тупим предметом або удару об предмет, дії повітряної хвилі (онтузія). Характеризується болем, набряком, крововиливом, стійкими порушеннями функцій уражених тканин, органів. 


\section{PEDAGOGY IN MODERN CONDITIONS}

Ми запитали у респондентів: «У чому полягає перша медична допомога при забитті?». Пропонувалось обрати 3 наступних варіантів: А) прикладення зігріваючого компресу; Б) накладення тугої пов’язки, прикладення «холоду»;

В) накладення шини; Г) змазування забитого місця йодом.

Правильно відповіли 71,9 \% школярів, вказавши, що перша медична допомога при забитті полягає в накладанні тугої пов'язки. Всі решта варіанти отримали низький відсоток.

На питання, які суб’єктивні ознаки порушення діяльності серця під час виконання фізичних вправ Ви знаєте, респонденти відповіли наступним чином: 41,3 \% вказали на біль і відчуття важкості за грудиною; біль, що віддає у ліву руку. 35,5 \% назвали на зниження швидкості виконання вправ; 12,5 \% відповіли, що це підвищення частоти дихання та 10,7 \% назвали варіант - зниження швидкості виконання вправ.

На питання анкети: «Яким способом не потрібно витягувати потопаючого на берег?», ми запропонували наступні варіанти - А) захопити за голову; Б) захопити за плечі; В) захопити під руки; Г) тягнути за ноги.

Правильно відповіли 44,8 \% школярів назвавши варіант - Г. На всі решта варіантів припала незначна кількість відсотків.

Таким чином, з 20 питань анкети, на дванадцять 3 яких відповіла найбільша кількість респондентів правильно. Згідно табл. 1, 12 - 13 тестових завдань відповідають достатньому рівню навчальних досягнень. Отже, дослідження теоретичних знань з фізичної культури учнів 8-их - 9-их класів, свідчить про їх достатній рівень навчальних досягнень. 


\section{7 Теоретичні основи культурологічно-оріснтованого середовища формування культурологічної компетентності майбутніх учителів початкової школи}

Актуальність культурологічної зорієнтованості професійної підготовки майбутніх учителів початкової школи вимагає прискорення модернізації тих iï складників, які ефективно вплинуть на якість освітнього результату. До таких ми відносимо, зокрема, управління, організація освітнього процесу, зміст, спосіб передачі і засвоєння професійного досвіду відповідно до законів і принципів культури в широкому й вузькому розумінні. У контексті досліджуваної проблеми обгрунтування ролі в освітньому процесі такого феномену як культурологічно-орієнтоване освітнє середовище педагогічного навчального закладу передбачає пошук ефективних механізмів управління його створення, функціонування й розвитку для забезпечення культурологічних очікувань здобувачів вищої освіти, як сегмента підвищення якості професійної підготовки загалом.

Важливість цілеспрямованого створення освітнього середовища для ефективного формування культурологічної компетентності зумовлена тим, що наявність суперечностей, які виникають у процесі професійної підготовки майбутніх учителів початкової школи (відмінності у вимогах викладачів, неузгоджені дії учасників освітнього процесу щодо реалізації культурологічної компетентності, неувага до питань педагогічної i особистісної культури студентів, ігнорування їхньої потреби в максимальній самоідентифікації та самореалізації у контексті культурологічної діяльності тощо) здатні суттєво знизити результати спеціально організованої системи формування досліджуваного педагогічного явища [56].

Розуміння ролі й місця освітнього середовища в організації освітньої системи повинні узгоджуватись із пріоритетними функціями освіти культурологічного спрямування. На думку вчених це такі функції: людинотворча, технологічна, гуманістична, які органічно поєднуються 3 навчально-виховними функціями (С. Гончаренко); транслятора культурного 
досвіду, чинника соціалізації, адаптації й розвитку людини (В. Луговий); філософську, яка відображає в людській свідомості об'єктивний світ, суспільну практику, спрямовані на еволюцію особистісного досвіду (О. Новіков); культурну, економічну, продуктивну, інноваційну (С. Сисоєва); соціальної стабільності, економічного добробуту країни й національної безпеки (В. Кремень). У такому контексті роль освіти полягає у визначенні стратегії розвитку суспільства, перетворюючи його із «суспільства сьогодні» на «суспільство завтра» й виступає, як засіб управління розвитком суспільства [57].

Зазначимо, що вчені вирізняють пріоритетні ознаки освітнього середовища, які характеризують: відповідність типовим i конкретним історичним умовам (К. Абульханова-Славська); опертя на цілі й варіативність освіти з урахуванням важливих адекватному розвитку особистості факторів (П. Каптєрєв, В. Козир); упливає на формування й розвиток особистості в тому числі на самоформування й саморозвиток (О. Неділя, І. Сікорський, Д. Фельдштейн). Своєю чергою, освітнє середовище ЗВО розглядається як психолого-педагогічна реальність, що містить спеціально організовані умови для формування особистості майбутнього фахівця та можливості для іiі розвитку, включені в соціальне і просторово-предметне оточення, сутністю якого $є$ сукупність взаємодій i особистісних особливостей учасників освітнього процесу, змісту освіти, способів його засвоєння [58]

Варто зазначити, що освітне середовище ЗВО розглядається не лише 3 погляду адаптації особистості до суспільних умов, підготовки до виконання певних соціальних ролей, а як таке, що надає можливості для розвитку творчих здібностей особистості, зміни іï внутрішнього світу, особистісних рис, життєвих пріоритетів. Таким чином, за своєю природою освітнє середовище - це інтегральна система умов $\mathrm{i}$ ресурсів прямого й опосередкованого впливу на особистість (матеріальних, фінансових, особистісних, технологічних, організаційних) у процесі здобуття освіти, що створюються цілеспрямовано в закладі вищої освіти, який виконує основні 
функції щодо надання освітніх послуг здобувачам вищої освіти, забезпечує можливості для загальнокультурного й індивідуального розвитку суб'єктів освітнього процесу. У зв'язку з цим, культурологічно-орієнтоване середовище найближче до освітньо-виховного процесу в навчальному закладі і виступає, з одного боку, як засіб у розв'язанні культурологічних завдань у системі освітніх процесів, а з іншого - як результат системної освітньої діяльності, яка реалізовується в культурологічному вимірі професійної підготовки майбутніх учителів початкової школи.

Таке середовище характеризується сукупністю матеріальних і моральнодуховних чинників і засобів, що сприяють трансформації особистості майбутніх учителів початкової школи у процесі опанування професійними освітніми завданнями, спрямованими на культурний, інтелектуальний, мистецький і творчий розвиток. Зважаючи на зазначене вище, вважаємо, що освітнє середовище, яке за метою, функціями, змістом спрямоване на формування культурологічної компетентності, як складника професійної компетентості майбутніх учителів початкової школи загалом, $\epsilon$ культурологічно-орієнтованим середовищем.

3 метою визначення основних функцій культурологічно-орієнтованого середовища ми спираємось на аналіз наукової літератури 3 проблеми підвищення ефективності освітніх процесів у контексті реалізації філософії культури (В. Андрєєв, Г. Батищев, Н. Бердяєв, Т. Георгієва, М. Коул, Н. Крилова, В. Розін, В. Ясвін ін.), який дозволив поєднати обгрунтування щодо дієвості культури в еволюції освіти, що є основою теоретичного осмислення місії культурологічно-орієнтованого середовища ЗВО з різними аспектами вищої педагогічної освіти, як бази практичного змісту спеціальноорганізованого середовища формування культурологічної компетентності майбутніх учителів початкової школи.

Важливим, як показує аналіз теорії культури (А. Арнольдов, В. Козирєв, Н. Крилова, В. Лекторський, С. Моложавий та ін.), є питання про основні функції культури в царині людинотворення. Серед них учені виділяють 
головні: перетворювальна, яка відповідає необхідності пристосовувати природу, включаючи і природу самої людини, до потреб суспільства; організаційна - відповідає необхідності створення моделі майбутнього; пізнавальна, яка забезпечує накопичення і поглиблення знань про об'єктивні закони буття; ичіннісно-орієнтацуійна, що відповідає необхідності консолідації суспільства єдиними ідеалами, оцінками, нормами людської культури; комунікативна, яка забезпечує спілкування людей усіма засобами культури; соціальна, що відповідає потребам конкретної соціальної системи; регулююча, дозволяє корелювати громадські стосунки і поведінку людей відповідно до загально прийнятих норм; адаптивна, що встановлює i врегульовує відповідність між особистістю й умовами зовнішнього середовища в цілях самозбереження [59].

Як доведено вченими (Г. Батищев, А. Валицька, Л. Виготський та ін.), в усіх варіантах освіта тією чи тією мірою інтегрується 3 культурою, утворюючи цим iï органічну складову. Звідси, створення культурологічноорієнтованого освітнього середвища можна розуміти як процес організації спеціальної системи, що забезпечує засвоєння комплексу культурологічних знань, орієнтацій і досвіду інтегруючись у систему професійної підготовки опанування особистістю відповідного фаху.

Тому очевидно, що необхідно створити таке спеціально спрямоване середовище, яке становить частину загального освітнього середовища ЗВО. Це дасть змогу охопити об’єкт і предмет досліджуваної проблеми у більш глобальному контексті, моделювати освітній процес із максимально точним наближенням до мети, систематизувати й інтегрувати фахові знання, використовувати їх для спільного розв’язання такого складного комплексного утворення, як формування культурологічної компетентності майбутніх учителів початкової школи.

Отже, культурологічно-орієнтоване середовище - це складник (сегмент) освітнього середовища ЗВО, який сприяє соціалізації й інкультурації особистості майбутнього фахівця в освітньому процесі на засадах реалізації 
культурологічної парадигми. Відтак, створення культурологічноорієнтованого середовища відображає підтримку культурологічної стратегії діяльності 3ВО, що підтверджується реалізацією культурних, моральноетичних принципів надання освітніх послуг, наслідування кращих культуроосвітніх практик у сфері вищої освіти, підтримання професійної репутації закладу освіти на високому рівні.

Своєю чергою, мета створення культурологічно-орієнтованого середовища - це узгодження умов, засобів, змісту освітнього процесу 3 активізацією всіх особистісних сфер студентів у напрямі засвоєння ними системи культурологічних знань, умінь, навичок, які дозволяють професійно самореалізуватись і бути рівноцінним суб'єктом сучасного полікультурного суспільства, зокрема соціокультурного простору закладу вищої освіти.

Таким чином, створення культурологічно-орієнтованого середовища передбачає слідування наступним ціляям сформувати у всіх суб’єктів педагогічної взаємодії цілісне усвідомлення й сприйняття необхідності формування культурологічної компетентності в межах професійної підготовки у будь-яких іiі проявах; узагальнити ключові положення культурологічного характеру нормативно-регулятивного аспекту професійної підготовки майбутніх учителів початкової школи державного, регіонального й локального (заклад освіти, структурний підрозділ закладу освіти) рівнів; сприяти процесу формування культурологічної спрямованості, готовності, обізнаності, активності, самодостатності у всіх суб'єктів культурологічноорієнтованого середовища (внесення до планів діяльності факультету, кафедр, органів студентського самоврядування, академічних студентських груп позицій культурологічного характеру тощо).

Проведений аналіз наукових першоджерел дозволяє нам визначити основні функиії створення культурологічно-орієтованого середовища професійної підготовки майбутніх учителів початкової школи: людиноцентрична (сприяє реалізації потенціалу студентів в особистому й професійному самовизначенні й самореалізації, формуванню особистості, як 
PEDAGOGY IN MODERN CONDITIONS

носія духовності і культури в широкому й вузькому розумінні), освітньопрофесійна (стимулювання інтегрально-синергетичної природи культурологічної компетентності у контексті професійної компетентності і триєдиної освітньої мети: навчальної, виховної і розвивальної), культуротворча (сприяє соціалізації й інкультурації особистості, реалізаціі гуманістичної концепції освіти, особистісно-орієнтованого підходу, дозволяє використовувати культурологічний потенціал усіх компонентів освітньопрофесійних програм, інтегруючи навчальні, виховні, розвиваючі функції дисциплін); сощіалізащійна (випрацювання у фахівців соціально-культурних механізмів адаптації до ефективного здійснення професійної діяльності відповідно до динамічних й еволюційних соціальних процесів, наслідування культурно-історичного досвіду); адаптивно-розвивальна (спрямована на діагностику культурологічної i професійної спрямованості студентів i визначення стратегічних траєкторій і методів стимулювання, підсилення й розвитку культурологічно-орієнтованих мотиваційно-потребових інтересів здобувачів освіти для ефективного виконання професійних функцій, відповідаючи запитам суспільства) [60], [61], [7].

Отже, у зв’язку з цим, створення культурологічно-орієнтованого освітнього середовища в межах професійної підготовки майбутніх учителів початкової школи розуміємо як динамічний, відкритий освітній процес інноваційного характеру, який розвивається відповідно до суспільних запитів на підготовку культурологічно компетентних учителів початкової школи, характеризується єдністю i цілісністю, поєднує колективний та індивідуальний досвід культурологічної діяльності суб'єктів педагогічної взаємодії й забезпечує формування культурологічної кометентності майбутніх учителів початкової школи. Створення такого середовища $є$ педагогічно керованим процесом забезпечення умов 3 метою засвоєння студентами культурологічно-комунікативних стратегій і тактик педагогічної взаємодії. 


\section{8 Психолого-педагогічний супровід розвитку художньої культури майбутніх вихователів в умовах сучасного вишу}

У сучасний динамічний час в системі освіти відбувається перегляд цілої низки освітніх проблем. Відповідаючи на виклики часу, стратегія сучасної вищої освіти націлена на «забезпечення високої художньо-естетичної освіченості і вихованості особистості» (проект «Національної державної комплексної програми естетичного виховання», автори І.Зязюн, О.Семашко). В педагогічній професійній діяльності, естетичне освоєння дійсності є соціальним явищем, i завдання освітньої роботи полягає у тому, щоб прилучати вихованців до цінностей Добра та Краси. Розуміння цього положення відображено в державних стандартах освіти, законах, доктринах та концепціях. Так, за «Концепціею національного виховання» серед основних задач - формування естетичної культури, розвиток естетичного досвіду особистості, її художніх здібностей [64].

У «Базовому компоненті дошкільної освіти України» освітня лінія «Дитина у світі культури» спрямована на формування почуття краси в іiі різних проявах, ціннісного ставлення до змісту предметного світу та світу мистецтва, розвиток творчих здібностей дітей дошкільного віку [63].

Спираючись на наукові джерела сучасних дослідників, в яких розглянуто питання художнього, естетичного, творчого розвитку особистості педагогів Л.Масол, Н.Миропольська, О.Рудницька, Г.Падалка, О.Щолокова, визначаємо процес розвитку художньої культури майбутніх вихователів як синтез художньої та загально-естетичної культури особистості, художнього досвіду, художнього потенціалу, творчого ставлення до професійної діяльності, яке зумовлене впливом мистецтва.

Процес розвитку художньої культури майбутніх вихователів передбачає створення умов для самовизначення особистості студента в культурі, засвоєння iï як процес особистісного відкриття, створення світу культури в собі.

За висловом О. Рудницької, «художня культура є сукупністю процесів і явищ духовно-практичної діяльності людини, яка створює, розповсюджує і 
PEDAGOGY IN MODERN CONDITIONS

опановує твори мистецтва, а також матеріальні предмети, які $є$ естетично цінними» [8]. Художня культура здатна формувати духовні і художні потреби на особистісному й професійному рівнях, розвивати художний світогляд, готовність до мистецького діалогу, уміння сприймати й інтерпретувати твори мистецтва, тощо.

Особистість живе і діє в умовах культури, а культура наповнює іï собою. У такій взаємодії з культурою людина виступає об'єктом іiі впливу, носієм культурних цінностей та суб'єктом культуротворчості [8].

Найбільш грунтовно зміст художньо-естетичної культури педагога розкриває І.Зязюн. Він розглядає естетичну культуру педагога як багатоаспектне явище, яке охоплює: форми пізнання дійсності (сприймання, уявлення, судження, почуття, цінності, діяльність); розуміння особистістю естетичної сутності дійсності та мистецтва; здібність до художньо-естетичної діяльності у різних галузях (малювання, музикування, віршування тощо) [7].

Художньо- естетична культура педагога, охоплює ціннісні орієнтації, духовно-моральні засади, взаємозв’язок складових (естетичного смаку, почуттів, суджень, понять, ідеалів) та включеність студентів в естетичну діяльність та характеризується тим, що в результаті сформованості естетичної свідомості, розвиненого естетичного почуття і смаку, здатності до художньо-естетичної діяльності забезпечується їх готовність до естетичного виховання дітей.

У загальній культурі педагога естетичний аспект виконує такі функції:

- гносеологічну, таку, що має свою специфіку, обумовлену змістовною частиною предмету;

- художню, об'єднуючу різні види художньої діяльності, мистецтв, використання принципів, методів, прийомів;

- використання принципів, методів, прийомів педагогіки, психології, етики, естетики, соціології, культурології й мистецтвознання;

- евристичну, яка має діалоговий характер реалізації, співтворчість художника, виконавця, слухача, глядача; 
PEDAGOGY IN MODERN CONDITIONS

- виховну, тісно пов'язану з гносеологічною і евристичною функціями, орієнтовану на формування естетичних і етичних якостей особи;

- розвиваючу, націлену на вдосконалення інтелектуальних, емоційних i вольових здібностей, розвиток творчої активності, формування етичноестетичної особистості [7].

Художньо-естетична культура майбутнього педагога на думку О. Отич, є якісним, системним і динамічним утворенням особистості, що характеризується певним рівнем його естетичного розвитку і художньо-педагогічною освіченістю, свідомістю способів досягнення цього рівня, який призводить до духовноморального вдосконалення, адаптації до соціального оточення i творчої самореалізації у професійної педагогічної діяльності [ 6].

Вчена наголошує, що в процесі формування естетичної культури вдосконалюється особистість педагога, а саме, їі естетичне ставлення, естетична свідомість та естетична діяльність; відбувається чуттєве освоєння і перетворення навколишньої дійсності і самої особистості за законами краси відповідно до естетичного ідеалу. Отже, фахівець без широкого культурного кругозору втрачає у своєму творчому розвитку, не досягає професіоналізму, тому що «в культурі все взаємопов’язане - праця, наука, мораль, мистецтво. Це лише різні грані єдиного цілого» [6].

Формування художньої культури майбутніх вихователів розуміється як навчально-освітня діяльність, що спрямована на отримання естетичних знань, умінь, уявлень, переконань, почуттів, навичок і норм діяльності та становлення на їх основі естетичного світогляду особистості, бажання жити за законами краси.

Розвиток художньої культури майбутніх вихователів повинен бути науково обгрунтованим, що здійснюється при впровадженні наукового підходу. Одним із таких підходів є психолого-педагогічний супровід - наукова система діагностики, підтримки та корекції розвитку майбутніх фахівців в освітньому процесі. Проаналізувавши літературні джерела, зазначимо, що психологопедагогічний супровід (ППС) розвитку художньої культури майбутніх 


\section{PEDAGOGY IN MODERN CONDITIONS}

вихователів - це особлива форма здійснення педагогічної та психологічної допомоги, корекція особистісного розвитку, актуалізація художньо-творчих ресурсів студентів, виявлення їх власних можливостей, творчих здібностей та створення на цій основі умов для реалізації художнього потенціалу.

Розглядаючи особливості організації психолого-педагогічного супроводу 3 розвитку художньої культури студентів факультету дошкільної педагогіки i психології в освітньому процесі вишу, виокремлюємо такі напрями його організації (табл.1).

Таблиця 1

Організація психолого-педагогічного супроводу з розвитку художньої культури студентів майбутніх вихователів

\begin{tabular}{|c|c|c|}
\hline & U & Зміст \\
\hline 1 & 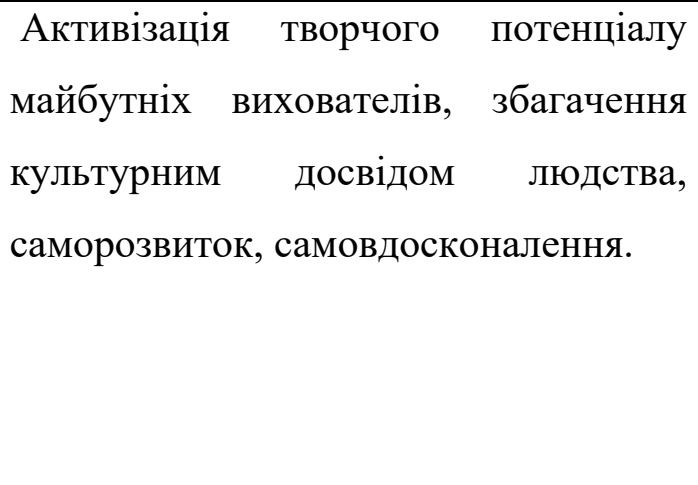 & $\begin{array}{l}\text { Спрямованість на сприйняття естетичного у } \\
\text { процесі художньої творчості, } \\
\text { характеризується потребою у прагненні } \\
\text { виокремлювати й розрізняти естетичне в } \\
\text { оточуючому; залучення до цінностей світової, } \\
\text { художньої культури, класики і сучасного } \\
\text { мистецтва різних видів і жанрів. }\end{array}$ \\
\hline 2 & $\begin{array}{l}\text { Формування мотивації до творчості, } \\
\text { самостійна } \quad \text { художня діяльність та } \\
\text { розвиток творчого потенціалу }\end{array}$ & $\begin{array}{l}\text { Естетико-педагогічна } \\
\text { зумовлює наявність } \\
\text { культурології, теорії та істість } 3 \text { естетики, мистецтва; } \\
\text { комплекс практичних умінь та навичок в галузі } \\
\text { художньої діяльності. }\end{array}$ \\
\hline 3. & $\begin{array}{l}\text { Створення психолого-педагогічних } \\
\text { умов для забезпечення власного } \\
\text { процесу творчості - стимулювання } \\
\text { художньої діяльністі }\end{array}$ & $\begin{array}{l}\text { Створення середовища, що надає можливість } \\
\text { студенту аналізувати й оцінювати естетичне у } \\
\text { мистецтві, художній діяльності; сприяє } \\
\text { розвитку естетичних почуттів, потреб, ідеалів, } \\
\text { художнього смаку. }\end{array}$ \\
\hline 4 & $\begin{array}{l}\text { Забезпечення } \\
\text { підходу на оснивідуального } \\
\text { особливостей кожного студента. }\end{array}$ & $\begin{array}{l}\text { Моніторинг художньо-творчого розвитку } \\
\text { майбутніх вихователів; виявлення та підтримка } \\
\text { художньо обдарованих студентів. }\end{array}$ \\
\hline
\end{tabular}


PEDAGOGY IN MODERN CONDITIONS

\begin{tabular}{|c|c|c|}
\hline 5 & \begin{tabular}{|lrr} 
Підвищення & \multicolumn{2}{c}{ психологічної } \\
компетентності за умови & вивчення \\
арт-педагогічних & й & арт- \\
терапевтичних технологій. &
\end{tabular} & $\begin{array}{l}\text { Подолання кризових ситуацій у творчої } \\
\text { самореалізації; озброєння майбутніх педагогів } \\
\text { новітніми технологіями, які позбавляють від } \\
\text { шаблонного мислення, настанов; використання } \\
\text { творчих технік: ізотерапія (монотипія, пісок, } \\
\text { фотографія, колаж, спонтанне малювання); } \\
\text { мандалотерапія (малювання, плетіння); } \\
\text { глінотерапія і тістопластика; музеетерапія. }\end{array}$ \\
\hline
\end{tabular}

Базовими принципами психолого-педагогічного супроводу розвитку художньої культури майбутніх вихователів було обрано такі:

- принцип науковості та доступності знань: адаптація відповідних наукових знань з урахуванням особливостей вікових категорій, взаємозв'язок естетичної культури як частини філософського знання з практичним досвідом;

- принцип системності: процес формування естетичної культури відбувається у природних і спеціальних умовах, формування організовується як системний педагогічний процес, в логічному зв'язку всіх його етапів;

- принцип продуктивності підкреслює прагматичність художньої діяльності, обов'язковість її орієнтації на здобуття результату, що має прикладну значущість;

- принцип культурної аналогії - ознайомлення з культурними надбанями людства в галузі образотворчого мистецтва, націлений на формування власного погляду, смаку, з метою вивчення культурно-історичних аналогів;

- принцип інтегративності - синтез теоретичних, емпіричних і практичних знань $з$ теорії й практики в галузі художньої культури;

принцип відкритості (систематичне поповнення, оновлення, вдосконалення знань про естетичну культуру;

- принцип гуманізму (орієнтація на особистість, як вищу цінність, врахування вікових та індивідуальних особливостей, задоволення фундаментальних потреб особистості.

Психолого-педагогічній супровід розвитку художньої культури майбутніх 
вихователів відбувається за такими педагогічними умовами:

1. розробка i комплексне використання спеціальних освітньопрофесійних завдань, пов'язаних із сприйняттям прекрасного в житті і в мистецтві, здатність здійснювати художньо-творчу діяльність;

2. використання технології особистісно-орієнтованого навчання; діалогічного взаєморозуміння суб'єктів освітнього процесу, що забезпечує суб'єктну позицію майбутних вихователів;

3. створення емоційно-естетичного середовища.

Розглядаючи методи, яки було застосовано у процесі ППС, зупинимось на проблемному методі, який дає можливість розвинути самостійне мислення, дослідницькі уміння, творчий підхід до справи. Даний метод передбачає наявність теоретичних і експериментальних завдань. Викладач створює на занятті ситуацію пізнавальної проблеми, адже майбутні вихователі повинні вирішити проблему, спираючись на розумові операції: аналіз, синтез, порівняння, аналогію, узагальнення і ін.

Проектний метод застосовувався для:

— розвитку творчого мислення студентів бакалаврату;

— розвитку здібності до прогнозування, уявного передбачення кінцевого результату;

— накопичення багажу знань про матеріальну і духовну культуру.

Методи самосвідомості: самоспостереження, самоаналіз, рефлексія, сприяють розвитку творчого потенціалу. При цьому студент бакалаврату виступає одночасно суб'єктом і об'єктом самоспостереження, оскільки є носієм безпосереднього досвіду, який сформувався у конкретному середовищі. Дані методи дозволяють вивчити процес поетапного вдосконалення системи особистісних здібностей, знань, умінь, як складових частин творчого потенціалу; вимагають від студентів аналізу фактичних явищ, результатів своєї діяльності 3 розвитку творчого потенціалу; дозволяють встановити як найсильніші, так і слабкіші сторони власної художньої творчості, діагностувати 


\section{PEDAGOGY IN MODERN CONDITIONS}

спектр своїх здібностей.

Дослідницькі методи (експеримент, евристичне прогнозування, моделювання) передбачають створення нового, творчу переробку в нових умовах того, що було вивчене: методику, технологію; раціоналізацію своєї діяльності; інтеграцію раніше відомих методик, художних технік.

Широко використовувались освітньо-професійні завдання: розробка i комплексне використання спеціальних завдань, пов'язаних із сприйняттям прекрасного в житті і в мистецтві, готовністю і здатністю здійснювати художньо-творчу діяльність; що забезпечує ефективне формування естетичного ставлення майбутнього вихователя.

Термін «освітньо-професійні завдання» у науковій літературі визначається як різноманітна за змістом і об'ємом самостійна робота, що виконуються за завданням педагога. Освітньо-професійні завдання є проблемними завданнями, тому, що мета діяльності реалізується при частковому або повному незнанні способу їі досягнення і передбачає удосконалення старого або створення нового. Дані завдання у процесі професійної підготовки майбутніх вихователів були націлені на розвиток певних розумових операцій, видів мислення (наочнообразного, абстрактно-логічного, критичного); розвиток пізнавальної самостійності і активне входження у художню діяльність.

Навчально-професійна діяльність студентів спрямовувалась на розвиток художньої культури за допомогою виконання структурних, художньостилістичних, візуально-образних, емоційно-змістовних завдань.

Задля творчого виконання композиційних, колористичних, конструктивних завдань на заняттях 3 «Основ образотворчого мистецтва» було запропоновано різні техніки і матеріали, а саме: робота з фарбами; аплікація, колаж з паперу, тканини, природних матеріалів; воскова крейда; туш, гуаш; пастель, графітний олівець, гелеві пензлі (табл.2). 
Таблиця 2.

Змістова наповненість психолого-педагогічного супроводу 3 розвитку художньої культури майбутніх вихователів

\begin{tabular}{|c|c|c|c|}
\hline Тема & Зміст & Матеріал, техніка & Методи \\
\hline $\begin{array}{l}\text { Закони i } \\
\text { правила } \\
\text { зображення }\end{array}$ & $\begin{array}{l}\text { Опрацювання понятійного } \\
\text { апарату: засоби } \\
\text { Колір, форма, композиція } \\
\text { (академічна, декоративна, } \\
\text { формальна). } \\
\text { Співвідношення форм в } \\
\text { композиції } \\
\text { пропорції, модуль). } \\
\text { Статика, динаміка, симетрія, } \\
\begin{array}{l}\text { асиметрія, композиційний } \\
\text { центр, ритм, кольоровий } \\
\text { контраст }\end{array}\end{array}$ & $\begin{array}{l}\text { Коллаж, фроттаж. } \\
\text { Робота з фарбами, за } \\
\text { мотивами } \\
\text { художників- } \\
\text { імпресіоністів, } \\
\text { пуанталістів. }\end{array}$ & \begin{tabular}{|l} 
Творче \\
проектування, \\
проблемні \\
методи
\end{tabular} \\
\hline \begin{tabular}{|l} 
Види \\
рівноваги \\
композиції, \\
колірна \\
гармонія
\end{tabular} & 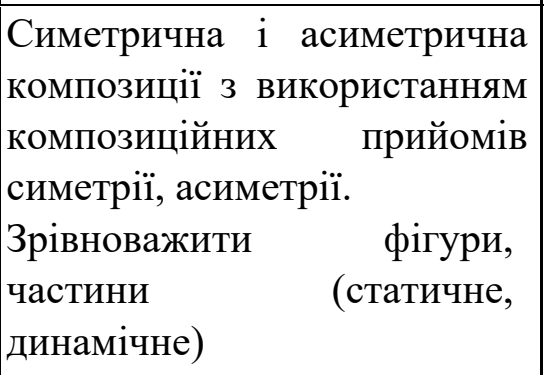 & $\begin{array}{l}\text { Коллаж, аплікація } 3 \\
\text { паперу, тканини, } \\
\text { природних матеріалів } \\
\text { за мотивами фризів } \\
\text { древнього Египту }\end{array}$ & $\begin{array}{l}\text { Проблемні } \\
\text { завдання } \\
\text { Майстер-класи } \\
\text { за різними } \\
\text { художніми } \\
\text { техніками. }\end{array}$ \\
\hline $\begin{array}{l}\text { Кольорова } \\
\text { організація } \\
\text { композиції }\end{array}$ & $\begin{array}{lr}\text { Створення } & \text { декоративної } \\
\text { композиції } & \text { за } \\
\text { чергування } & \text { рахунок } \\
\text { спадання і наростання ритму; } \\
\text { розмірів, кольору, тону і ін. }\end{array}$ & $\begin{array}{l}\text { Робота пастеллю, } \\
\text { коллаж, робота у стилі } \\
\text { «кубізм». }\end{array}$ & $\begin{array}{l}\text { Майстер-класи, } \\
\text { методи } \\
\text { евристики }\end{array}$ \\
\hline \begin{tabular}{|l|} 
Контрастні \\
співвідношення
\end{tabular} & $\begin{array}{l}\text { Виконання композиції с } \\
\text { контрастом по тону (темне } \\
\text { світле). } \\
\text { Виконання композиції } 3 \\
\text { контрастом за масштабом } \\
\text { модулів (велике і мале) }\end{array}$ & \begin{tabular}{|lr} 
Граттаж. & Робота \\
тушшю, & гуашшю, \\
гелевими пензлями за \\
мотивами & грецького \\
вазопису &
\end{tabular} & $\begin{array}{l}\text { Евристичне } \\
\text { прогнозування, } \\
\text { моделювання }\end{array}$ \\
\hline
\end{tabular}


PEDAGOGY IN MODERN CONDITIONS

\begin{tabular}{|l|l|l|l|l|}
\hline $\begin{array}{l}\text { Побудова } \\
\text { простору } \\
\text { композиції }\end{array}$ & $\begin{array}{l}\text { Створити композицію 3 } \\
\text { тональними контрастами }\end{array}$ & $\begin{array}{l}\text { Пастель, графітний } \\
\text { карандаш, робота у } \\
\text { стилі «символізм». }\end{array}$ & $\begin{array}{l}\text { Освітньо- } \\
\text { професійні } \\
\text { завдання }\end{array}$ \\
\hline Творча робота & $\begin{array}{l}\text { Виконання декоративної } \\
\text { композиції }\end{array}$ & $\begin{array}{l}\text { Робота 3 фарбами та } \\
\text { штампами } \\
\text { мотивами } \\
\text { Петриківського } \\
\text { розпису }\end{array}$ & $\begin{array}{l}\text { Проблемні } \\
\text { завдання }\end{array}$ \\
\hline
\end{tabular}

В сучасних умовах дистанційного освітнього процесу психологопедагогічний супровід здійснювався у режиме онлайн-лекції та майстер-класів (участь через платформу Zoom), проводились дискусії та опитування (участь через платформу Word Office 365), виконувались самостійні завдання (взаємодія на платформі Word Office 365).

Запропоновані студентами роботи свідчать про позитивні порушення. Студенти виявляють інтерес до мистецтва; художніх творів різних стилів й жанрів; розуміють умовність и засоби виразності художнього образа у образотворчому мистецтві, вміють творчо інтерпретувати образний зміст художніх творів; виявляють ерудицію в галузі образотворчого мистецтва; розуміють духовну наповненість шедеврів світового мистецтва. В художньотворчій діяльності вільно володіють виразними засобами живопису та графіки, вірно застосовують технічні можливості олівця, акварелі, гуаш:, мову лінії й колориту для самовираження. 


\section{9 Актуалізація науково-дослідницької діяльності як чинник професійного зростання майбутнього магістра музичного мистецтва}

Соціальні трансформації, що відбуваються сьогодні в суспільстві, окреслили контури новітньої освітньої парадигми, суть якої визначається зміщенням основного акценту в діяльності педагога як функціонального виконавця на актуалізацію творчих аспектів педагогічної праці й науководослідницької діяльності. Сучасному суспільству потрібен фахівець, який здатний до відтворення нових ідей, пошуку нетривіальних і в той же час оптимальних рішень в нестандартних професійних ситуаціях, до активної участі в інноваційних процесах, до неперервної самореалізації й саморозвитку.

Однак наразі все ще спостерігається відсутність у певної частини як майбутніх, так і практикуючих фахівців-музикантів готовності до науковотворчого переосмислення власної діяльності відповідно потреб сьогодення. Причини такого положення криються в усталеній практиці професійної підготовки майбутніх педагогів з музичної освіти і виховання, яка все ще не забезпечує повною мірою сформованості у них необхідних компетенцій та досвіду здійснення науково-дослідницької діяльності на творчій основі.

Творчість є невід'ємною частиною й вагомим підгрунтям науководослідницької діяльності, адже перша перетікає в другу щоразу, коли фахівець вирішує узагальнити свій досвід, впровадити в свою роботу будь-які новітні технології тощо, що потребує опанування відповідних методологічних підходів, принципів та методів дослідження, які дозволяють отримати об'єктивні данні про результати його науково-творчих досягнень. Тож, актуалізація проблеми сформованості у майбутніх фахівців-музикантів здатності осмислювати свою професійну діяльність 3 наукових позицій, володіти достатнім рівнем дослідницької культури, що є не тільки необхідним атрибутом професійної підготовки майбутнього фахівця-музиканта, а й як його професійним обов'язком сьогодні $є$ дійсно на часі. Й в першу чергу, це стосується студентів освітньопрофесійного рівня «магістр музичного мистецтва», кваліфікація якого передбачає здатність аналізувати та прогнозувати художньо-творчий розвиток 
особистості в сучасних соціокультурних умовах; досліджувати комплексні перетворення в системі мистецької освіти та можливості подолання протиріч іiі розвитку; розглядати різноманітні соціокультурні об'єкти як цілісні явища, що проектуються в музично-педагогічну дійсність; співвідносити цілі викладання свого предмету з метою розвитку сучасної особистості як людини культури, а також розпізнавати тенденції оновлення змісту музичної освіти і виховання.

Аналіз змісту чинних освітньо-професійних програм і навчальних планів освітнього рівня «магістр», ми дійшли висновку, що головною причиною недостатньої обізнаності випускників у цьому напрямку є відсутність чітко визначеної спрямованості на підготовку магістранта як суб’єкта науководослідницької діяльності, підручники й посібники, що рекомендуються студентам, не мають необхідної й достатньої інформації щодо розвитку дослідницьких компетенцій; в процесі педагогічної асистентської практики студентам не завжди надається можливість зайняти позицію суб'єкта науководослідницької діяльності.

Тож, професійна підготовка майбутнього магістра музичного мистецтва до науково-дослідницької діяльності має бути спрямована на розвиток специфічних характеристик, що визначають його суб' єктність й є необхідними для їі ефективного виконання[65]. До таких характеристик ми відносимо, перш за все, вмотивованість, котра визначається бажанням досягти високого рівня професійного саморозвитку й самореалізації; потребу в отриманні компетенцій, що необхідні для вирішення дослідницьких завдань у професійній діяльності; наявність уміння орієнтуватись в отримуваній інформації та іiі коректне використання в побудові траєкторії наукового пошуку, а також здатність використовувати комплекс дослідницьких методів безпосередньо в практичній діяльності.

Вважаємо, що процес розвитку вищезгаданих якостей майбутнього магістра музичного мистецтва відбуватиметься більш ефективно за рахунок підсилення практичної складової його професійної підготовки через впровадження інноваційно-орієнтованих курсів, що побудовані з урахуванням 
сучасних потреб ринку праці [66], використання сучасних інноваційних технологій в процесі опанування традиційних дисциплін та впровадження науково-дослідницького проєкту «Віват магістри!».

Зазначений проєкт передбачає оновлення змісту професійної підготовку студентів-магістрів за напрямками, що забезпечують розвиток їхньої дослідницької культури та ефективність майбутньої практичної діяльності.

Теоретично-дослідницька робота передбачає: знайомство 3 новітніми освітніми концепціями, філософією освіти і мистецтва, принципами нової мистецької парадигми, інноваційними методами викладання; вивчення наукової літератури, що поглиблює розуміння особливостей й специфіки викладання фахових дисциплін відповідно обраної спеціалізації, знайомство 3 інноваційними технологіями у музичній педагогіці; науково-пошукову діяльність з метою обгрунтування теоретичних засад та актуальності обраної для кваліфікаційного магістерського дослідження проблеми; ознайомлення 3 оновленими положеннями щодо організації освітнього процесу в мистецьких закладах вищої освіти та чинними програмами 3 фахових дисциплін; ознайомлення 3 освітніми програмами робочими програмами 3 фахових дисциплін, що складені професорсько-викладацьким складом кафедр; узагальнення науково- педагогічного досвіду провідних фахівців у галузі мистецької освіти і виховання.

Практично-дослідницька робота потребує: створення портфоліо для репрезентації професійного зростання та вдосконалення фахових компетенций студента під час аудиторного навчання й асистентської педагогічної практики; розробки та презентації творчих проектів відповідно фахової спеціалізації студента-магістранта; самоаналізу власної готовності до самореалізації у мистецькій художньо-творчій та науковій діяльності; проведення дослідницько-експериментальної роботи 3 обраної теми кваліфікаційного магістерського дослідження; підготовки наукового повідомлення по підсумкам асистентської практики та результатам виконання поставлених мистецьких освітньо-педагогічних завдань; внесення пропозицій щодо удосконалення 
асистентскої практики як засобу професійної підготовки майбутніх магістрів музичного мистецтва.

Практично-педагогічна робота передбачає: відвідування магістрантами лекційних, семінарських, практичних та індивідуальних занять 3 фахових дисциплін, що проводяться професорсько-викладацьким складом кафедр музичного спрямування; підготовку до проведення лекційних, практичних та індивідуальних занять з фахових дисциплін (на першому етапі - за допомогою викладача-методиста, на другому - самостійно); проведення розроблених лекційних, практичних й індивідуальних занять 3 фахових дисциплін зі студентами бакалаврату; оволодіння сучасними педагогічними, мультимедійними та цифровими технологіями та інтерактивними методами викладання дисциплін фахового циклу; активну участь у міжнародних , всеукраїнських, університетських науково-практичних конференціях, творчих проектах та інших позанавчальних заходах; самоаналіз проведеної наукової та навчально-виховної роботи в період асистентської практики [67].

Зазначений проект побудовано за принципом проектного навчання, що містить такі його складові як унікальність, залучення до реалізації певної кількості учасників, об’єднаних загальною метою, конкретний термін виконання й, головне - спрямованість на практично значущий результат.

Реалізація проекту розрахована на послідовне його розгортання протягом як навчальної діяльності студентів, так і в процесі асистентської практики, яку магістранти проходять в стінах закладу вищої освіти. Його головною перевагою, у порівнянні 3 традиційним навчанням, стало очевидне підвищення мотивації студентів магістратури щодо участі в такого роду діяльності, оскільки вони усвідомили необхідність особистісного й професійного саморозвитку для успішної самореалізації не тільки в рамках проекту, а й для майбутнього професійного зростання.

Під час проведення асистентської практики основним завданнями якої є поглиблення й розширення теоретичних знань із фахових та психологопедагогічних дисциплін і застосування їх у вирішенні конкретних музично- 


\section{PEDAGOGY IN MODERN CONDITIONS}

педагогічних завдань; набуття навичок викладання фахових дисциплін за освітнім рівнем «магістр»; набуття здатності організовувати основні форми навчання у вищій школі; застосування інноваційних технологій i методик навчання; формування умінь професійного й педагогічного спілкування зі студентською аудиторією; виховання професійно-особистісних якостей викладача ЗВО та потреби в саморозвитку, самовираженні й самореалізації.

В той же час, у відповідності з запропонованим проектом, де студент поставлений у центр навчального процесу, кожне із завдань має вирішуватись 3 позицій індивідуально-творчого підходу, коли майбутній фахівець трансформує власні знання відповідно виникаючим ситуаціям, розвиває здатність до подальшого конструювання та використання знань, що забезпечує розвиток його творчого потенціалу як основи ефективної дослідницької діяльності .

Щодо програми науково-дослідної роботи студентів в період асистентської педагогічної практики [65], вона передбачає роботу студентів по двох магістральних напрямках. Перший 3 них пов’язано 3 ознайомленням 3 діяльністю кафедр мистецького спрямування щодо науково-дослідної роботи, зокрема напрямками та розділами програми іiі наукового розвитку; аналізом науково-методичної бази діяльності кафедр та дослідженням ефективності iї науково-дослідних розвідок, зокрема оцінюванням ступеня застосування інноваційних технологій.

Другий напрямок пов’язано 3 організацією власної науково-дослідної діяльності студентів магістратури. Це стосується наукових розвідок за темою кваліфікаційної магістерської роботи (визначення параметрів дослідження та здійснення операціоналізації його основних понять, розробка методології та методів дослідження, визначення процедури збирання первинної інформації та узагальнення результатів науково-аналітичної роботи у вигляді висновків та рекомендацій тощо), а також реалізації набутих компетенцій безпосередньо в процесі практичної педагогічної діяльності: проведенні лекційних, практичних та індивідуальних занять $з$ фахових дисциплін та позааудиторної роботи $3 і$ студентами бакалаврату. 


\section{PEDAGOGY IN MODERN CONDITIONS}

Організована таким чином науково-дослідницька діяльність являє собою інноваційну форму інтегрованої профільної підготовки майбутніх магістрів музичного мистецтва, забезпечує становлення й розвиток складових їхньої дослідницької культури й може стати одним із варіантів удосконалення науководослідницької діяльності магістрів як суб’єктів професійного розвитку. 


\subsection{0 Дидактико-виховні аспекти вивчення української народної вишивки майбутніми вчителями}

У сучасних умовах освіта виступає важливим чинником відродження нації, виховання у молоді національної свідомості, гідності, що викликає необхідність подальшої переорієнтації освітнього процесу в педагогічних закладах освіти. Надзвичайно важливо, щоб цей процес мав національну спрямованість, формував гармонійно розвинену особистість майбутнього вчителя - носія кращих надбань національної та світової культури, здатного до саморозвитку й самовдосконалення, до передачі власного творчого досвіду вихованцям.

Здійснюючи дослідження, нами враховувалися положення про педагогічний потенціал декоративно-ужиткового мистецтва, його психологічний вплив на формування національної самосвідомості, розвиток творчої активності, естетичного смаку, образного мислення тощо як учнів (Р. Захарченко,
П. Ігнатенко,
О. Кравець,
Н. Кузан, Т. Люріна,
В. Мусієнко,
С. Павх, Р. Скульський, С.Чебоненко), так і студентів (Л. Евас, В.Наулко, Л.Оршанський, В.Сидоренко, М.Стельмахович, С.Сявавко, Д.Тхоржевський). Зокрема, у дослідженні Л.Ейвас зазначається, що зміст фахової підготовки у педагогічних закладах вищої освіти не сприяє в достатній мірі формуванню у студентів необхідного рівня спеціальних знань й умінь, естетичного смаку, творчих здібностей, тому потребує вдосконалення відповідно до сьогоднішніх потреб національної школи [70].

Найпопулярнішим видом декоративно-ужиткового мистецтва українців $\epsilon$ народна вишивка. Проведений аналіз педагогічного досвіду викладання української народної вишивки та іiі виховних можливостей у формуванні національної самосвідомості студентської молоді доводить, що вивчення цього виду народного мистецтва викликає закономірний інтерес у студентства та здійснює на нього позитивний виховний вплив. На думку переважної більшості опитаних студентів і викладачів $(85,6 \%)$, цей вплив полягає у тому, що теоретичні знання, отримані на заняттях, полегшують процес вивчення рідної історії, мови, культури, сприяють усвідомленню ментальності українського народу, а набуті вміння і навички - розвивають гармонійність відчуття кольорів, 


\section{PEDAGOGY IN MODERN CONDITIONS}

композиційність мислення, метафоричність орнаментального декору.

Нами встановлено, що позитивних результатів формування національної самосвідомості студентів можна досягти у випадку поєднання таких чинників: по-перше, уведення культурологічного компоненту національного спрямування в структуру знань з української народної вишивки, а, по-друге, орієнтування студентів на самостійне вивчення культури і побуту українського народу. Крім цього, навчання та виховання у педагогічному закладі вищої освіти має грунтуватися на психологічному механізмі активації розвитку пізнавальної активності студентів. При цьому необхідно врахувати, що національна самосвідомість, характер і світогляд успішно формуються тоді, коли студенти готові не лише теоретично пізнати, а й практично продовжити культурноісторичні, наукові, мистецькі традиції свого народу.

Ураховуючи наведені позиції, ми хотіли привернути увагу до важливості вивчення майбутніми вчителями різних видів народного декоративноужиткового мистецтва, зокрема, й української народної вишивки, і показати, що зміст цієї підготовки має невичерпні можливості щодо формування високої духовності, національної самосвідомості студентів. Одним із напрямів реалізації цієї мети є взаємодія практичного навчання, естетичного виховання і творчого процесу шляхом прилучення до національних скарбів української культури, щоб цими засобами формувати у студентів високі норми й принципи моралі, прагнення до саморозвитку, духовних потреб.

Твори декоративно-ужиткового мистецтва мобілізують виховні ресурси особистості, викликають у неї духовний резонанс, який впливає на культурнотворчу діяльність людини [69].

Результатом художньо-трудової діяльності на заняттях 3 української народної вишивки є виготовлення конкретних декоративно-ужиткових виробів, оздоблених ручними швами в народних традиціях, які оцінюється за гармонією кольорів, орнаментальністю, композиційністю, технікою виконання. Вищевказані критерії дозволяють оцінити, як студенти оволоділи за час навчання спеціальними знаннями, уміннями та навичками. Однак цей зовнішній 
бік освітнього процесу не відображає внутрішні, глибинні зміни, які проходять у свідомості студентів, розвитку їхніх естетичних смаків, формуванні національної самосвідомості [70].

Вивчення української народної вишивки розпочинають зі вступного заняття, на якому викладач доводить до відома студентів мету і завдання, зміст та структуру й організаційні особливості проведення занять. На цьому занятті демонструються творчі роботи студентів-випусників з різних видів народного декоративно-ужиткового мистецтва (якщо мова йде про практичну частину кваліфікаційних робіт). Подається інформація про участь викладачів та їх учнів у різноманітних виставках регіонального, всеукраїнського і міжнародного рівнів [73]. Така інформація супроводжується демонструванням світлин, буклетів, альбомів, каталогів. Практичний досвід роботи свідчить про те, що подібна бесіда значно підвищує інтерес студентів до вивчення української народної вишивки, оскільки вони можуть реально спілкуватися з людьми, які працюють над створенням іміджу нашої держави, гідно представляють ії за кордоном [72]. Студенти бачать реальні можливості демонстрування своїх майбутніх робіт на виставках різного рівня - починаючи від університетських до міжнародних $\mathrm{i}$ можливості захисту авторських робіт на звання майстра народного мистецтва.

Водночас студенти мають змогу прослідкувати взаємозв’язок навчальної, наукової і творчої роботи у процесі вивчення дисциплін художньо-прикладного циклу [74].

Науково-дослідницька робота студентів зумовлює глибоке засвоєння навчального матеріалу. Важливим аспектом інтенсифікації та розширення поля дії освітнього процесу, як було вказано вище, є творча, навчально-методична, науково-дослідницька робота викладачів кафедри. Творча робота стає первинним видом експериментальної дослідницької роботи. У процесі навчання студенти набувають професійні навички в проектуванні й реалізації у матеріалі своїх творчих задумів. Кінцеві роботи свідчать про те, що студенти володіють композиційними засобами та здатні передавати естетичне сприйняття навколишнього світу і процесів, які в ньому відбуваються, у художніх формах. 
Якщо метою творчої роботи є розвиток художніх здібностей студентів, а кінцевим результатом - випускова кваліфікаційна робота 3 обов'язковою реалізацією творчого задуму в матеріалі, то важливим завданням дослідницької роботи студентів є подальше засвоєння та поглиблення методики проведення наукових досліджень у галузі народного мистецтва. А це передбачає оволодіння методикою навчально-дослідної роботи; виявлення взаємозв'язків між профілюючими дисциплінами у освітньому процесі; опрацювання (практичне в ескізах та готових зразках і теоретичне - в дослідженнях) тем науководослідницької роботи студентів згідно з програмою конкретної профілюючої дисципліни та їх захист; обмін навчально-науковими повідомленнями та новою мистецтвознавчою, методичною, технічною інформацією тощо.

Науково-дослідницька робота студентів розпочинається з першого курсу та триває впродовж усього періоду навчання. Робота над науковою проблемою передбачає збір матеріалу (в музеях, на виставках, у бібліотеках, науковометодичному фонді кафедри), його розробку (класифікація, систематизація, характеристика, аналіз тощо) й одержання кінцевих теоретичних і практичних результатів. Теоретичні результати роботи полягають в умінні на основі зібраного матеріалу науково обгрунтувати творчий задум проекту. Практичні результати - це реалізовані за власним задумом у матеріалі зразки декоративноужиткових виробів. Тематика науково-дослідницьких робіт обирається досить гнучко, тобто вона розробляється локально або в комплексі з іншими, і повинна мати перспективу розвитку. Наш педагогічний досвід засвідчує, що знання шляхів реалізації та участь студентів у різних напрямах науково-дослідницької та творчої роботи зумовлює глибоке засвоєння навчального матеріалу, активізує освітній процес, стимулює ініціативу, формує прийоми методи й навички професійної наукової та творчої діяльності.

3 першого заняття, вказуючи на основні напрями діяльності студентів, викладач наголошує на важливості оволодіння словниковим запасом і вивченням особливостей самобутньої національної культури. Про виняткове значення мови, як засобу спілкування між людьми, що впливає на їхню свідомість і формування 
національного світобачення, йдеться у багатьох літературних джерелах. Мова $є$ головною складовою етнокультури того чи іншого народу. Виходячи з цієї концепції, можна зробити висновок, що менталітет нації, погляд іiї представників на навколишню дійсність утворюються саме завдяки рідній мові, через взаємодію $з$ якою приходить знання та глибоке розуміння культури й особливостей української нації.

Формування національної самосвідомості на етнографічному матеріалі має будуватися таким чином, щоб студенти ознайомлювалися, залежно від конкретних педагогічних ситуацій, із народними прислів'ями, фольклором, які є справді міцним джерелом народного гумору, кмітливості, культури.

Суттєвого значення для усвідомлення таких відомостей набуває уява студентів, завдяки якій забезпечується поглиблення зв'язку між знаннями та почуттями, між інтелектуальним й емоційним. Саме уява сприяє мислиннєвоемоційному перенесенню студента в ситуацію або середовище тих подій, про які він дізнається через зміст навчального предмета [76]. У цьому випадку знаходить прояв закон реальності почуттів, механізми якого спрямовують особистість на усвідомлення свого відношення до закладених у зміст навчального матеріалу подій i фактів. Світ декоративних образів та яскравих кольорів, простих i доступних форм творів декоративно-ужиткового мистецтва захоплює студентів, викликає насолоду, підносить до стану натхнення, створюючи тим самим психологічний комфорт. Це перший етап «діалогу» із красою. Подальше глибоке спілкування зі світом прекрасного активізує емоційний стан студентів, викликає до життя творчу уяву, стимулює фантазію, виявляє художнє відчуття, формує образне мислення.

Перші заняття з української народної вишивки показують, що безпосереднє включення деяких студентів у творчу художньо-трудову діяльність не викликає позитивних емоцій здебільшого через непідготовленість до сприймання народного мистецтва. Проте в тих студентів, які прагнуть досягти високого рівня майстерності, процес творчої діяльності завжди викликає інтерес і збуджує позитивні емоції. Ці емоції підкріплюють вищі соціальні мотиви, а також $є$ 
додатковим стимулом, поштовхом до інтенсивнішої індивідуальної діяльності.

Вивчення української народної вишивки має відбуватися на автентичних зразках традиційного декоративно-ужиткового мистецтва. «Взаємозв’язок української народної вишивки 3 народним артбізнесом простий: із виробу мистецького вона перетворилася на ринкову річ, яка у своїй основі має не естетичну, а товарну функцію. І це стало для неї фатальним. Утрата мистецьких критеріїв, орнаментальної чистоти, суто традиційних регіональних прикмет, якісних характеристик симптоматична в плані збіднення традиційної соціокультурної сфери. Відтоді, як вишивка вийшла за межі домашнього вжитку на простори ринкових відносин, вона почала губити свої естетично-художні якості, втрачати виражальні можливості, чистоту стилістики. Вона стала предметом комерції, що сповідувало зниження технології, а заразом спонукало розвиток аматорства в цій галузі» [68] - ось ще одне підтвердження думки про те, що вивчення студентами української народної вишивки повинне відбуватися на старовинних зразках.

Відомо, що характерною ознакою творчого процесу є притаманна йому діалектична єдність руйнування старого й створення нового, однак для того щоб створити щось нове у галузі традиційного декоративно-ужиткового мистецтва, не обов’язково руйнувати старе. Творчий аспект у національній культурі розуміється не лише як створення нових духовно-матеріальних цінностей, але як процес щодо їх збереження, передачі та споживання, адже тут творчість здійснюється на основі відповідного теоретичного й соціокультурного фонду минулого практичного досвіду. У народній творчості відбувається пластичне перетворення об’єкта, а також внутрішнього світу, інтелектуальної енергії духу суб’єкта через створення реальних декоративно-ужиткових речей.

Оскільки традиції відіграють важливу роль у підтримці духовних зв’язків поколінь, забезпеченні культурної наступності, то намагання зберегти їх - це не екстенсивні потуги, а охоронне ставлення до специфіки художньої мови вишивального мистецтва. Тренувальний «рушничок» із виконаними зразками старовинних швів одразу перетворюється в наочно-методичний посібник для 
майбутнього вчителя. В подальшій роботі його можна використовувати як самостійний демонстраційний посібник i як матеріал для виготовлення методичних стендів на зразок «Україна у вишивці» чи «Регіональні особливості української народної вишивки». Водночас, такий «рушничок» містить невичерпний матеріал для композиційних розробок виробів, оздоблених ручними швами. Розглянутий підхід стимулює студентів до відповідального ставлення при виконанні тренувальних вправ із перших занять.

Важливішим першоджерелом національної самосвідомості українців $\epsilon$ міфологія, фольклор, символіка наших далеких предків епохи трипільської культури, Київської Русі, періоду Українського Відродження XVI - першої половини XVII ст. У цих та інших пам’ятках національної культури відображені спосіб мислення, самобутній світогляд українського народу, багатство його інтелектуальних дій і засобів пізнання.

Національні символи нами розглядається як засіб сприймання народної традиції. Українська національна символіка надзвичайно багата й тісно пов'язана 3 національними звичаями, обрядами, ритуалами та святами. Під символом прийнято розуміти умовне позначення якого-небудь предмету, поняття чи явища, а під символікою - умовний вираз ідей, понять, почуттів [71]. Іноді символіку зводять до атрибутики, що є неправильним, бо атрибут виявляє невід’ємну властивість предмета чи явища, i має пряме, a не символічне значення. В ролі атрибутів може виступати одяг учасників обряду, оформлення приміщення. Чітка орієнтація в цих поняттях допомагає зрозуміти виховну сутність символіки. Рівень педагогічної продуктивності символу забезпечується ступенем його зацікавленості, тлумаченням і розумінням студентами.

Досвід роботи показує, що тема символіки народного мистецтва є дуже цікавою для студентів. Після ознайомлення 3 нею вони не пропускають нагоди вкласти глибокий символічний зміст у композиційні розробки майбутніх вишивок. Семантичний підхід до вивчення народного декоративно-ужиткового мистецтва дозволяє студентам глибше розкрити зміст, закладений у конкретну форму чи декор, де за зовнішньою ясністю зображення мотиву, символу чи знаку 
приховані ідеї, вірування, естетичні смаки. Декодування знаково-символічної системи, знання композиційно-структурної мови й оперування нею у творчій практиці сприяє формуванню декоративно-образного мислення студентів.

3 погляду декоративно-ужиткового мистецтва, значення кольору нерозривно пов'язане з культурною традицією, що сформувалася та існує впродовж багатьох століть. У процесі виконання завдань студенти повинні усвідомити, що сучасна кольорова символіка грунтується на асоціативності кодових принципів і містить відповідні символи 3 геральдики, теології, психолого-емоційні поняття, поетичні метафори тощо. Колір-знак, колірметафора характеризують певні поняття як пізнавального, так і емоційновиражального плану [76]. Таким чином, колір у творах декоративно-ужиткового мистецтва може виконувати комунікативну (поділ, акцентування, об'єднання та інша організація візуальної інформаціі), пізнавальну (кольорові символи й знаки, кодування) і головне - виражальну функцію. Саме остання активно впливає на художню образність створених студентами декоративно-ужиткових виробів, викликаючи у них відповідні емоції та естетичні почуття.

Методологічний принцип психології про єдність свідомості й діяльності стверджує: свідомість не тільки проявляється, а й формується у діяльності [75]. Враховуючи вище викладене положення, методика навчання української народної вишивки передбачає виконання комплексу завдань, покликаних одночасно виконувати навчальну і виховну функції. Ці завдання підпорядковані загальній меті - збирання й оформлення навчально-методичного матеріалу для виготовлення в школі (за місцем майбутньої роботи) мистецько-етнографічної карти «Україна у вишивці». Виконання завдань передбачає не лише дослідження i збирання окремих зразків вишивки, а й вивчення географії поширення комплектів народного одягу, характерних для різних регіонів, їх історії виникнення i розвитку на різних територіях України, місць і способів розміщення узорів на вишитих виробах.

Наступним комплексом завдань $є$ вивчення народного одягу та місце вишитих виробів у ньому. Принагідно зауважимо, що французького походження 
поняття «костюм» в українській мові має відповідні терміни - стрій, вбрання, убрання, шати. При виконанні цієї групи завдань студенти мають можливість прослідковувати вплив на українські строї різних чинників: природних умов, мистецької спадщини попередніх поколінь, культурного взаємовпливу з іншими народами, прояву творчості народу, розвитку технологій виробництва, а також способу життя й основних занять народу, його національних особливостей, релігії, суспільної моралі тощо [77]. При вивченні українських національних строїв необхідно обов’язково простежувати спадковість явищ духовної та матеріальної культури від найдавніших часів до наших днів. Вивчаючи їх, необхідно звертати увагу не лише на автентичні зразки одягу, а й на літературні джерела, археологічні матеріали, іконографію, живописні полотна.

Найпоширенішою формою в практиці підготовки майбутніх учителів за нашою методикою виступає самостійна робота студентів, яка грунтується на дослідницьких завданнях пошукового характеру. Їх тематика пов’язана 3 декоративно-ужитковим мистецтвом рідного краю та його традиціями. Щоб краще зрозуміти народне мистецтво рідного краю, студентам пропонується вдома (для жителів міста - у сільській місцевості) здійснити пошук і дослідити зразки старовинних вишивок, художніх виробів з дерева, металу, опрацьовувати орнаментику, колористику, техніки декорування. Справа в тому, що дерев’яна архітектура і ткацтво, кераміка та розпис, різьба і вишивка кожного окремого регіону мають глибокий, хоч і не очевидний взаємозв'язок. Та й усі види фольклору (музичний, словесний, драматичний, образотворчий) демонструють різні грані єдиного цілого. Недарма методика сучасної науки про народне мистецтво при вирішенні дослідницьких завдань передбачає неодмінне залучення матеріалів усної творчості, звичаїв, повір’їв, широке використання інструментарію суміжних дисциплін (етнографії, фольклористики, лінгвістики, археології, культурологіï).

Такий збір етнографічного, мистецького матеріалу сприяє розвитку композиційного мислення студентів, глибокому вивченню народних традицій, розширює їх творчу уяву, спонукає до пошуку нових орнаментальних 
композицій. Під час збору цього матеріалу студенти ознайомлюються з межами етнографічних зон України, складом населення, типами говору, житлом i поселенням, архітектурою, обрядами, святами, народними промислами та ремеслами, життям і діяльністю народних майстрів.

У процесі виконання завдань майбутні вчителі починають краще розуміти, що саме їм у майбутній професійній діяльності необхідно буде звертати особливу увагу на вивчення локальних художніх традицій оздоблення декоративно-ужиткових виробів, досконало володіти техніками декорування, а також добре знати історію і мистецтво рідного краю.

При виконанні завдань студенти знайомляться з науковими методами збору та оформлення матеріалів. Для цього необхідно скласти план і графік проведення експедицій, ознайомитися з етикетом ведення бесід, навчитися паспортизувати зібрані матеріали. Паспорт повинен відображати такі дані: назву декоративноужиткового виробу; назву села чи міста, де знайдено виріб; приблизну дату виконання; особливості орнаментики, колористики і техніки виконання виробу; матеріал, з якого виготовлений виріб та його основне призначення. Крім цього, потрібно зібрати дані про автора, якщо це можливо. Під час експедиції необхідно змальовувати орнаменти, декоративні форми, звертати увагу на місцеві назви художніх технік і технологій виготовлення. Серед назв орнаменту часто зустрічаються такі, що відображають місцевість, наприклад, назву села, із якого він походить. Елементи орнаментальних композицій, змальовані студентами 3 автентичних виробів, використовуються під час проведення практичних занять для складання власних орнаментальних композицій, моделювання й оздоблення одягу у народному стилі, оформленні інтер'єру приміщень.

Досліджуючи зразки вишивок, студенти вчаться читати в орнаментальних текстах події суспільного життя. Дослідивши їх смислове значення, вони самостійно складають композиції, виготовляють вироби, які стають оберегами в їхніх домівках, або зашифрованим посланням прийдешнім поколінням. Цінні старовинні матеріали, предмети побуту рекомендуються для поповнення експозицій краєзнавчого музею міста або для оформлення етнографічних кімнат 


\section{PEDAGOGY IN MODERN CONDITIONS}

у закладі вищої освіти.

Метою підсумкового заняття, на якому організовується виставка творчих залікових робіт, $є$ демонстрування майстерності студентів. Адже якість декоративно-ужиткових виробів оцінює весь студентський колектив. Задля ефективного проведення оцінювання рівня виконавчої майстерності студентів нами запроваджуються заняття-захисти залікових творчих робіт. Таке заняття, спрямоване на узагальнення та систематизацію вивченого, перенесення знань, умінь і навичок у нестандартні умови. Розвиваючи вміння студентів аналізувати й оцінювати виконаний проект декоративно-ужиткового виробу, треба намагатися, щоб оцінки студентів носили доброзичливий та об'єктивний характер, щоб вони вчилися бачити та оцінювати роботу у комплексі відповідних критеріїв і називати у першу чергу позитивні якості учасників художньотрудової діяльності.

Таким чином, найважливішим чинником формування особистості майбутнього вчителя є освітній процес, який забезпечується передовсім змістом навчальних предметів, пов'язаних із професійною підготовкою, вибором пріоритетних напрямів, форм, методів і засобів виховного впливу з урахуванням нових соціально-політичних, правових, економічних умов, а навчальний курс «Українська народна вишивка», що вивчається студентами педагогічних спеціальностей у закладах вищої освіти України, поряд з іншими професійно орієнтованими дисциплінами, сприяє формуванню особистісних якостей, професійної та культурологічної компетентностей, національної самосвідомості і гордості за художньо-мистецьку спадщину українців. 


\subsection{1 Значення екологічної освіти в сучасному освітньому процесі та їі особливості}

В наш час - час бурхливого розвитку технологій в зв'язку з інтенсивним використанням природних ресурсів у всьому світі існує безліч екологічних проблем, у тому числі й глобального характеру. Забруднення атмосфери, літосфери та гідросфери, а також накопичення величезних об'ємів відходів призвели до розвитку екологічної кризи. Для вирішення даних екологічних проблем людству потрібна нова філософія життя, висока екологічна культура та свідомість. Лише тоді, коли людство оволодіє екологічними знаннями, методами та засобами захисту довкілля, утилізації відходів, ресурсозбереження, покращиться екологічна ситуація, а також виникне можливість оздоровити оточуюче середовище, здійснювати грамотні програми екологізації.

Як відомо, оптимізація взаємовідносин людини та природи, вироблення вмінь активно цілеспрямовано впливати на компоненти навколишнього природного середовища, не завдаючи йому шкоди не можливі без екологічних знань. Таким чином, в наш час екологічна освіта $\epsilon$ необхідною складовою сталого гармонійного екологічно безпечного розвитку суспільства [77 - 79], а також одним 3 пріоритетних напрямів державної політики будь-якої країни. Тому сьогодні в усіх розвинених країнах світу екологічна культура стає невід'ємною частиною функціональної грамотності населення.

Від екологічного знання залежить певний рівень ставлення людини до навколишнього середовища. Отже, грамотна екологічна освіта та виховання повинні здійснюватися 3 обов'язковим урахуванням екологічних законів, закономірностей, наукових принципів та орієнтуватись на активну взаємодію людини з природою, побудовану на науковій основі, на оцінюванні людини як частини природи [79]. Вона повинна враховувати соціально-культурні функції екології у суспільстві, цілісну структуру екологічних знань, сучасний рівень розвитку екологічної науки, традицій, звичаїв та історичний досвід народу в цій сфері, особливості екологічної та економічної ситуації в країні. 
PEDAGOGY IN MODERN CONDITIONS

Розвиток вищої екологічної освіти в будь-якій країні повинен базуватися на комплексному збалансованому поєднанні таких основних підходів: природничого, економічного, технологічного, юридичного та соціокультурного [81].

Вся екологічна освіта включає процеси навчання, виховання, розвитку особистості. Сучасна екологічна освіта повинна вміщувати як фундаментальні природоохоронні основи, так й інші прикладні сфери науки про охорону навколишнього середовища та природокористування [82 - 84].

На жаль, сьогодні в Україні екологічна освіта знаходиться в критичному стані. Причинами даної ситуації є $[79,85,86]$ : недооцінка екологічних знань у системі освіти; низький рівень впровадження у практику досягнень педагогічної науки; незнання та руйнування народних традицій раціонального природокористування; багаторічне панування споживацького ставлення до природи; слабке матеріально-технічне і методичне забезпечення навчальновиховного процесу тощо.

В основу екологічної освіти покладені такі основні принципи: науковості, гуманізму, неперервності, наскрізності та систематичності.

Для того, щоб правильно та якісно організувати екологічну освіту та виховання, а також підвищити їх ефективність необхідно керуватися такими основними вимогами $[79,86]$ :

- екологічна освіта i виховання повинні орієнтуватись на активну взаємодію людини з природою, побудовану на науковій основі, на оцінюванні людини як частини природи;

- навколишнє середовище та антропогенне середовище мають розглядатись як єдине ціле, підходячи до його оцінки i характеристик 3 екологічних, економічних, соціальних, законодавчих, культурних і естетичних позицій; повинно першочергове завдання надаватися екологічній освіті;

- необхідно дотримуватися міждисциплінарного підходу тощо. 


\section{PEDAGOGY IN MODERN CONDITIONS}

Методика викладання екологічних дисциплін повинна розв'язувати такі завдання: забезпечити формування в студентів умінь формулювати навчальну мету, вибудовувати та структурувати зміст лекційних, практичних занять.

Сучасний освітній процес висуває свої вимоги до методів навчання. Всі методи здобуття нових знань класифікуються за такими ознаками: методи організації та здійснення навчально-викладацької діяльності; методи стимулювання та мотивації навчально-пізнавальної діяльності; методи контролю та самоконтролю у навчанні.

Програми підготовки фахівців-екологів для забезпечення якісної екологічної освіти в усіх ВНЗ повинні передбачати [86]:

- міждисциплінарний підхід;

- вміння активно користуватись сучасними інформаційними технологіями для вирішення екологічних завдань;

- урахування та пізнання зв'язку екологічних проблем з економічними, культурними та соціальними проблемами.

Сьогодні все частіше при вивченні екологічних дисциплін, а також усіх інших дисциплін, в зв'язку зі санітарно-епідеміологічною обстановкою в багатьох країнах світу, все більша роль надається самоосвіті, методам активного пізнання, дистанційним освітнім програмам. Головним завданням дистанційного навчання є розвиток творчих, а також інтелектуальних здібностей за допомогою відкритого й вільного використання всіх освітніх ресурсів і програм. Але, як будь-який вид навчання, воно має як сукупність переваг та можливостей, так i недоліки, оскільки впровадження дистанційного навчання потребує від студентів високої мотивації, здатності до самостійної роботи та самоконтролю у процесі навчання, вміння вибудовувати власну освітню траєкторію, підвищувати комп'ютерні компетентності відповідно до нововведень і інновацій. Тому дистанційна форма навчання вимагає послідовного вирішення ряду важливих завдань у сфері організаційно-нормативного, програмного, навчальнометодичного, технічного та кадрового забезпечення [87]. Тільки тоді воно зможе стати ефективною формою навчального процесу. 


\section{PEDAGOGY IN MODERN CONDITIONS}

Таким чином, екологічні знання мають сприяти усвідомленню людських цінностей, допомагати вирішенню комплексних екологічних проблем, які стоять перед людством, забезпечити комфортність його проживання у майбутньому, зберегти та примножити унікальну різноманітність всієї біоти. Екологічна освіта, з одного боку, повинна бути самостійним елементом загальної системи освіти, а з іншого боку, виконувати інтегративну роль у всій системі освіти. 


\subsection{2 Поняття соціального аналізу якості вищої освіти в контексті формування професійної, загальної і соціальної компетентності здобувачів освіти}

Україна - соціальна держава, освіта - соціально-гуманітарна сфера інтересів держави. Тому результати вищої освіти є ознакою соціальності держави. Проблема підвищення якості освіти $є$ ключовою для реалізації права людини на освіту. Саме іiї вирішення входить до цілей політики сталого розвитку, створює умови для реалізації прав в суспільстві всіх людей, незалежно від їхнього майнового, соціального та ін. станів. Тобто аналіз якості освіти треба розглядати в контексті мети політики освіти для всіх. Як відзначає Р. А. Мадані [87], аналіз якості освіти є метою політики освіти для всіх, що є соціальним результатом освіти і предметом ii соціального аналізу. Саме рівні можливості доступу до освіти є ідеологією сталого розвитку. Але сьогодні карантинні заходи та дистанційні технології освіти, зокрема, облачні технології, з одного боку, обмежили цей доступ - 3 погляду обмеженості інтернет-зв'язку в різних куточках країни, раніше освіта в аудиторії не вимагала техніки, зв'язку, не ставила технічні вимоги до якості освіти, з іншого - посилили цей доступ через його можливості. Виникає нерівність у доступі до навчання і в результатах навчання.

Зазначимо, що якість освіти в суспільстві залежить конкретно як від зусиль кожної країни, її освітньої державної політики, ресурсів, можливостей, так і від зусиль самих громадян (здобувачів освіти) - в контексті факторів розвитку і соціалізації особистості, а саме активності особистості. Більш того, якщо сама якісна освіта в країні, що розвивається, залежить від різних факторів і теорій, зокрема, від теорії центральних місць [88], то активність самої особистості, навчання і виховання, мікросередовище були, $є$ і будуть провідними факторами розвитку і соціалізації особистості. Саме ці фактори залежать безпосередньо від педагогів і здобувачів освіти, на які вони можуть впливати і змінювати якість освіти і саме освітнє середовище в закладі освіти, в тому числі, через дистанційні цифрові технології, облачні технології. 
Суб'єктність та активність всіх учасників освітнього процесу також має відбиватися в результатах освіти, що найкраще демонструють загальні компетентності, в тому числі й соціальні. 3 іншого боку, професійні стандарти націлені на формування як професійних, так і загальних компетентостей особистості (які включають до себе соціальну компетентність). Під соціальною компетентністю розуміють «здатність до співробітництва в групі та команді, мобільність, уміння адаптуватись і визначати особисті цілі та виконувати різні ролі й функції в колективі, планувати, розробляти й реалізовувати соціальні проекти індивідуальних і колективних дій; уміння визначати й реалізовувати мету комунікації в залежності від обставин; підтримувати взаємини; розв'язувати проблеми в різних життєвих ситуаціях» [89]. В. Ковальчук визначає, що «соціальна компетентність є виключно важливою базисною характеристикою особистості, яка відображає іiі досягнення, рівень сформованості знань та умінь конструювати відносини з оточуючими людьми в міжособистісних стосунках, поведінці» [90]. Сьогодні соціальні і загальні компетентності є більш затребуваними роботодавцями, аніж професійні. Окрім того, соціальні компетентності вирішують проблеми соціалізації особистості молоді і набуття ними нових соціальних ролей більш успішно. Отже, соціальний аналіз якості освіти є важливим не менш, ніж традиційний щодо професійних компетентостей.

Тому соціальний аналіз освіти в ЗВО можна проводити 3 політики забезпечення освітніми програмами максимальної якості програм освіти для всіх [87], а також з погляду націленості на формування професійних, загальних, у тому числі соціальних, компетентностей особистості. Це відбиває ідею соціального призначення системи вищої освіти, іiї соціальні цілі в суспільстві. Аналіз якості вищої освіти, таким чином, повинен грунтуватися не тільки на інституалізації акредитації на європейських вимогах, які демонструють орієнтацію України на євроінтеграцію, механізмах і умовах для освітнього процесу, які зараз демонструє НАЗЯВО в контексті євроінтеграції, але й на результатах освітнього процесу в соціальному контексті. Проте НАЗЯВО таки 
певною мірою вимагає інструментів і механізмів для формування загальних (i соціальних) компетентостей. Онлайн-акредитації таких програм різних 3ВО 3 боку НАЗЯВО розпочалися влітку 2020 року і стосувалися програм в цілому за 4 роки з 2016 до 2020. Це сьогодні стосується залученості всіх зацікавлених сторін до оцінки якості освіти, соціальних, організаційних та інших умов для висловлення думки про якість освіти, пропозицій до її поліпшення. Зазначимо, що в умовах євроінтеграції та пандемії Україна розпочала процес забезпечення якості освіти на всіх освітніх рівнях законодавчо, політично, економічно, при цьому набирає обертів демократизація освіти, перевірка іiі якості, у тому числі через впровадження інституту стейкхолдерів (зацікавлених сторін у результатах навчання), механізмів їх визначення і опитування, який відбито в рекомендаціях НАЗЯВО до підготовки звітів з самоаналізу освітніх програм, у розроблених самими ЗВО і поданих на своїх сайтах положеннях про стейкхолдерів [91], анкети для виявлення їхніх інтересів [92]. Це відбиває інституціональний підхід до акредитації. Саме стейкхолдери надають побажання і зауваження до освітніх програм (змісту, форм і методів реалізації), реалізуючи цим самим свою активність і суб' єктність, але ми не побачили сьогодні цих зауважень і побажань щодо якості ОНП та ОПП в умовах карантину за допомогою дистанційної освіти, дещо обмеженими $\epsilon$ соціальні умови освіти: гуртожиток, психологічна підтримка, соціальна підтримка здобувачів освіти. Але результати і мета, зміст освіти в соціальному аспекті не $є$ предметом опитувань здобувачів на предмет їх побажань і включення питань і предметів в освітні програми різного рівня. У той час саме цей пункт наголошує на доступності програм i їх соціальному аспекті, приводить до формування конкурентоспроможного фахівця.

Відзначимо, що якщо формуванню професійних компетентостей присвячені окремі навчальні дисципліни, то загальні і соціальні компетентності не формуються однією навчальної дисципліною, навіть одним блоком дисциплін. Хоча побажання щодо їх формування слід писати в програмних результатах навчання і в професійних стандартах вищої освіти. 
Вища освіта, післядипломна освіта не є обов'язковими в Україні, тому підвищення їх якості сприяє підвищенню статусу осіб з вищої освітою і науковим ступенем, їх конкурентоспроможності в Україні та світі, євроінтеграції українських 3ВО і вчених, просуванню на світовий ринок вітчизняних досліджень, реалізації ідей наукової мобільності і наукової співпраці між країнами СС і Україною, підвищенню якості життя. У Посланні Саламанської конвенції європейських вищих навчальних закладів йдеться, що якість освіти найголовніша умова для довіри, релевантності, мобільності і привабливості вищої освіти для населення. Тому питання якості вищої і післядипломної освіти $€$ основою існування самої вищої освіти в країні. Підготовка ж науковопедагогічних кадрів прямо впливає на репутацію університетів і привабливість вищої освіти для населення. Якість же реалізації освітніх програм PhD впливає i на якість майбутнього викладацького складу 3ВО, його авторитет та імідж в громаді і суспільстві. Це також $є$ предметом соціального аналізу якості вищої освіти, соціальним і професійним результатом освітніх програм.

Сьогодні в Україні вже починає «переважати розуміння якості освіти в соціологічному контексті - тобто вже як конвенційного феномену, як результату узгодження між усіма учасниками освітнього процесу і співвіднесення їх потреб iз нормативними вимогами, прийнятими в системі освіти, та соціокультурними потребами, особливостями функціонування освітньої системи у суспільстві» [93]. За думкою С. Щудло, багатоманітні потреби різних суб'єктів освітнього простору актуалізуються в цьому ж соціумі та формуються ним [94]. Отже, виникає питання про механізми, інструменти соціального та соціологічного аналізу якості вищої освіти. Сьогодні ж інструменти соціального і соціологічного аналізу якості освіти на 3 рівні вищої освіти не є достатньо розробленими і впровадженими, узагальненими.

У дослідженнях і практиках ЗВО розкривається можливість узгодження побажань і зауважень стейкхолдерів, які можуть бути зовнішніми і внутрішніми, мати різні функції і впливи на зміст, форми і методи реалізації ОНП, ОПП, різні повноваження у ЗВО. Усе це можна узгодити через застосування механізму 
соціального партнерства, що розглядається нами як «особлива система освітніх відносин, що грунтується на демократичних принципах взаємодії та співпраці усіх зацікавлених освітніх суб’єктів, які об’єднані метою отримання бажаної якості вищої освіти» [94]. Тобто від здобувачів вищої освіти залежить само існування вищої освіти і функціонування іiі закладів. У сучасних дослідженнях зазначено, що «провідна проблема постає у визначені ідеальних показників освіти й умов у різних країнах, особливо у мало розвинутих... Відповідно, існує потреба у багатогранній точці зору й структурі міркувань для реалізації оцінок освітньої політики и структурі міркувань для реализації оцінок освітньої політики» [87]. Але орієнтирами, що є спільними для всіх країн, є наукові підходи до оцінки якості освіти: інституціональний, компетентнісний, системний тощо.

Оскільки України розпочала процес євроінтеграції і впровадження компетентнісного підходу, застосування європейських методик оцінювання якості освіти та демократизацію освітнього процесу, потрібно перш за все орієнтуватися на українські потреби і цілі суспільства до якості вищої освіти та потреби здобувачів вищої освіти в контексті євроінтеграції та глобалізації. Саме це реалізує ідею соціальних результатів освіти, $\epsilon$ результатом соціального аналізу якості освіти. Отже, ми згодні з думкою дослідників, що соціальний аналіз є основним методом практичного інструменту соціального управління освітою.

Виникає питання про те, як насправді сьогодні проводиться соціологічний аналіз якості вищої освіти за рекомендаціями НАЗЯВО, чи відповідають вони вимогам суспільства і здобувачів освіти.

Аналіз науково-педагогічних досліджень і чинного законодавства з освіти в Україні з проблеми розкриває:

- поняття якості освіти («Якість освіти - комплекс характеристик освітнього процесу, що визначають послідовне та практично ефективне формування компетентності та професійної свідомості. Це певний рівень знань і вмінь, розумового, фізичного й морального розвитку, якого досягли випускники 
освітнього закладу відповідно до запланованих цілей навчання і виховання» [95], вищої освіти («якість вищої освіти - відповідність умов провадження освітньої діяльності та результатів навчання вимогам законодавства та стандартам вищої освіти, професійним та/або міжнародним стандартам (за наявності), а також потребам заінтересованих сторін і суспільства, що забезпечується шляхом здійснення процедур внутрішнього та зовнішнього забезпечення якості» [96];

- наукові підходи до поняття якості вищої освіти (філософія освіти, яка якість освіти представляе як багатовимірну модель соціальних норм і вимог до особистості, освітнього середовища, в якому відбувається їі розвиток, та системи освіти, яка реалізує їх на певних етапах навчання людини [97]; інтуїтивноемпіричний через досвід та інтуїцію особи; формально-звітний через рівень успішності тих, хто навчається; психологічний через рівень розвитку пізнавальних процесів та ступінь прояву психічних новоутворень особистості; педагогічний через рівень виховності та навченості, а сьогодні вже компетентності здобувачів; процесуальний через оцінку стану освітнього процесу; результативний через оцінку результату педагогічної діяльності освітньої установи; комплексний через зовнішню експертиза (матеріальна база, кадровий склад, програми, форми та методи роботи); багатопараметричий завдяки оцінка діяльності освітніх закладів на основі внутрісистемних параметрів; методологічний - на основі співвідношення результату з операційно заданими цілями; інтегрований через уведення категорій, які носять інтегрований характер (компетентність, грамотність, освіченість); особистісноорієнтований на основі особистісний розвиток; соиіальний через ступінь задоволеності індивідуального та суспільного споживача [93];

- європейський вимір якості вищої освіти, його рекомендації, принципи, процедури. Так, сьогодні, на думку Г. Клімової [98], основними в оцінці ефективності освітньої діяльності вищих навчальних закладів у ЄС стають не планування i реалізація навчального процесу (зміст навчальних планів, навчальний час тощо), а результати освіти: отримані студентами знання, компетенції і навички, у тому числі за рахунок їх самостійного навчання й 
самоосвіти. Центр уваги зміщується із самого процесу навчання (навчальні програми, академічна успішність студентів) на компетентнісний підхід iз орієнтацією на професійну й особистісну підготовленість і в першу чергу до працевлаштування випускників. У цих умовах механізми забезпечення якості стають центральною складовою подібного управління системою освіти за результатами [98];

- окремі методики роботи з проблеми і проекти, рекомендації щодо підвищення якості освіти і вищої освіти (порадник для експертів НАЗЯВО, сайт $\mathrm{MOH})$.

Усі ці дослідження говорять про різні аспекти аналізу якості вищої освіти, але окремо соціальний аналіз вони не проводять на предмет траєкторії руху ЗВО в руслі євроінтеграції, глобалізації, орієнтації на кращі світові зразки i досягнення. У той час, як дослідники говорять, що в «широкому сенсі якість освіти розуміють як збалансовану відповідність процесу, результату і самої освітньої системи цілям, потребам і соціальним нормам (стандартам) освіти» [97]. Отже, соціальний аналіз відбиває закономірність педагогіки - залежність від потреб і цілей суспільства. Таким чином, він має педагогічний підхід до своєї суті.

Соціологічний підхід до якості вищої освіти передбачає аналіз системи освіти 3 цього питання як: соціального інституту, особливого виду діяльності, соціальної цінності для особистості та суспільства, при цьому в якості методологічних основ цього підходу до освіти, використовуються інституціональний, зовнішньо інституціональний, соціокультурний та соціокомунікативний) підходи [99]. 3 позицій цього підходу, освіта як соціальний інститут має права та обов'язки в суспільстві, особливий вид діяльності - сам освітній процес, який закінчується отриманням певного освітнього рівня і кваліфікації, диплома, соціальна цінність - визнання в суспільстві результатів освітнього процесу, розвиток самої особистості внаслідок освіти через застосування механізму соціального партнерства, що розглядається нами як особлива система освітніх відносин, що грунтується на 
демократичних принципах взаємодії та співпраці усіх зацікавлених освітніх суб’єктів, які об’єднані метою отримання бажаної якості вищої освіти [94].

На основі викладеного можемо говорити, що соціальний аналіз якості освіти - це аналіз соціальності мети, змісту освіти, іiі процесу і результату, умов для освітнього процесу, які мають соціальний аспект. Соціальний аналіз показує відповідність вищої освіти потребам суспільства, здобувача освіти і тих, хто освітній процес здійснює та організує. Його метою є формування у здобувачів освіти професійної, загальної (і соціальної в тому числі) компетентостей, які відповідають потребам і вимогам суспільства до випускника вищої освіти.

Методологією соціального аналізу вищої освіти є комплекс наукових підходів різного рівня, а саме: власне соціальний, інституціональний, зовнішньо інституціональний, соціокультурний та соціокомунікативний, педагогічний, особистісно-орієнтований, багатопараметричий, підхід філософії освіти, інтуїтивно-емпіричний, формально-звітний, психологічний, процесуальний, результативний, комплексний, інтегрований, методологічний підходи, а також підхід соціального партнерства, теорія участі. Соціальний аналіз освітніх програм повинен проводитися не тільки за допомогою соціального партнерства, а й за участю всіх стейкхолдерів, на кожному з етапів освітнього процесу і його складовим, з урахуванням ідей сталого розвитку суспільства, євроінтеграції, соціальної держави в Україні. На сьогодні маємо соціальний аналіз умов якості вищої освіти, але не соціальний аналіз їі мети, завдань, планів, змісту, технологій і методик освітнього процесу, результату тощо вищої освіти. Тобто соціальний аналіз не $\epsilon$ розробленим щодо якості вищої освіти. Механізмами та інструментами його можуть стати запозичення і перенос ідей з соціального підприємництва на предмет соціальності через його соціальний аудит як процесу і результату, який більш розроблений на сьогодні, аніж соціальний аналіз якості вищої освіти, SWAT-аналіз освітніх програм закладів вищої освіти на предмет соціальності при акредитації тощо. Також соціальні умови, які створені в закладі вищої освіти (кодекси етики, житлові умови, наявність опитувальників стейкхолдерів, положень про стейкхолдерів i їх права та 
PEDAGOGY IN MODERN CONDITIONS

обов'язки), що тільки починає своє становлення в системі вищої освіти i залежить від кожного члена колективу університету [100] i соціальна компетентність в програмних результатах навчання, яка обов'язкова до виконання всіма, хто реалізує освітні програми в закладах вищої освіти.

Перспективами подальших досліджень $є$ імплементація ідей соціального аналізу освітніх програм ЗВО в рекомендації НАЗЯВО в освітні програми всіх рівнів, як і соціальної компетентності в ці освітні програми, розробка механізмів та інструментів аудиту освітніх програм на предмет соціальності тощо. 


\subsection{3 Педагогічна школа видатного методиста Ніли Йосипівни Волошиної}

Будь-яка справа може рухатися та розвиватися лише за умов, коли до неї залучені справжні фахівці, діяльність яких передбачає високу компетентність, уміння наполегливо працювати, бачити найважливіші, найбільш актуальні та перспективні проблеми та шляхи їхньго вирішення. Таких людей небагато, але саме вони стають джерелом руху й досягнень, тому вони залишаються в історії як фундатори провідних наукових здобутків.

На межі тисячоліть саме такою, можна навіть казати, «знаковою» постаттю у методиці викладання українською та зарубіжної літератур у школі стала доктор педагогічних наук, професор, член-кореспондент Національної академії педагогічних наук України Ніла Йосипівна Волошина, до спадщини якої неодноразово звертаються дослідники, що аналізують стан методичної науки другої половини XX - початку XXI століття [104]. Науковцем вибудувано концептуальну парадигму літературної освіти школярів в Україні, наукові основи методики вивчення української літератури в загальноосвітніх і вищих навчальних закладах, концептуальні позиції програмо-підручникотворення, історичного досвіду колег-науковців, методистів, учителів-практиків як цілісності в його частковостях, специфіці, унікальності напрацьованого та визнаного різними поколіннями.

Назвемо основні етапи іiі становлення як науковця-професіонала, мудрого наставника, лідера:

- навчання у Славутському педагогічному училищі, на учительській стежині з 17 років;

- історико-філологічний факультет Кам'янець-Подільського державного педагогічного інституту й десять років плекання рідного слова 3 подолянамиучнями (1957-1967, с. Велике Залісся, Поділля); наступний етап - учительська і громадська діяльність на Київщині (1967-1972, середня школа № 1, м. Вишневе); двадцять років підряд (десять скликань) - депутат Вишнівської міської ради; 
- у 1977 р. - успішний захист кандидатської дисертації з проблеми естетичного виховання учнів старшої школи засобами мистецтва слова; з 1995 року - доктор педагогічних наук, у 1996 р. отримала атестат професора, з 1999 року обрана членом-кореспондентом АПН України; має державне звання заслужений діяч науки і техніки України (2004);

- 31972 року - молодший науковий співробітник, старший науковий співробітник (1978) лабораторії методики літератури НДІ педагогіки, завідувач лабораторії літературної освіти (1987-2005), заступник директора 3 наукової роботи (2006-2008) Інституту педагогіки АПН України, а з 2009 року головний науковий співробітник [100].

Вважаємо дуже важливим доказом ролі цієї школи в методиці викладання літератури наступне: після того, як десять років тому, у розквіті свого наукового потенціалу, Ніла Йосипівна пішла від нас, створена нею школа не зникла, не перетворилася на своєрідне «історичне явище». Навпаки. Підтвердженням цього вважаємо «Волошинські читання», які відбуваються щорічно. Вони являють собою не лише данину пам'яті видатного українського науковця, а завжди стають помітним явищем у методиці викладання літератури, оскільки учасники обговорюють найбільш актуальні питання цієї науки в сучасних умовах літературної освіти.

Отже, завдяки чому наукова школа Н. Й. Волошиної виявилася такою, так би мовити, «життєздатною»? Вважаємо, переконливу відповідь на це питання ще 10 років тому дав один із найбільш результативних на сучасному етапі розвитку методики викладання літератури вихованців Ніли Йосипівни, доктор педагогічних наук, заслужений учитель України, переможець Всеукраїнського конкурсу «Учитель року - 2000» Василь Шуляр. На його думку,наукові пошуки представників школи професора Волошиної ніколи не обмежувалися та й зараз не обмежується лише «фахом», тобто, методикою викладання літератури, ця школа на початку нашого століття перетворилася на надзвичайно помітний у методичній палітрі України «культурологічно-освітній простір, в якому культивується особистісне і професійно-фахове зростання науковців, 
забезпечуються умови для акме-розвитку кожного як Я-особистості, яка здатна логічно, послідовно розвивати ідеї свого Учителя-Лідера в ім’я Учня української науки і освіти» [102].

Унікальність й неповторність методичної школи Н. Й. Волошиної визначають «людиноцентричну» цілісність наукового середовища, яке створила Ніла Йосипівна: 5 докторів наук та майже 40 кандидатів, яких вона підготувала, досліджували й досліджують надзвичайне широке коло проблем, але все це складові загального задуму Учителя-Лідера. Широта наукових інтересів - це наслідок того, що засновниця школи розуміла літературну освіту як системний вплив на особистість учня-людини, формування цієї людини на підставі навчально-виховного потенціалу художньої літератури як явища мистецтва слова та культури у цілому.

Ніла Йосипівна в науці та житті була для кожного 3 нас справжнім «Учителем-Лідером», тому їі школа живе та розвивається, а наукові досягнення представників цієї школи виявляються такими вагомими, визнаними педагогічною спільнотою.

Отже, унікальність й неповторність створеної нею школи зумовлені особистістю Ніли Йосипівни, широким колом ii наукових інтересів, умінням залучити до наукових пошуків молодих дослідників, зацікавити кожного його темою, запалити, і це не перебільшення, прагнення самовіддано працювати та досягати результатів. При цьому не було якихось голосних «закликів», все досягалося, як кажуть, особистим прикладом: усі їі вихованці згадують, що поруч із такою людиною неможливо було не зацікавитися наукою, а їі ерудиція, обізнаність, педагогічний такт на сумлінне служіння науці унеможливлювали «роботу абияк», «відбування номер» замість справжніх наукових досліджень. Саме про цю особливість Ніли Йосипівні як чинник, що формував у кожного відповідальне ставлення до власної наукової діяльності, з великою вдячністю згадують їі вихованці у численних спогадах про свого наукового керівника [100].

Свого часу в окремій статті було докладно простежено роль особистості засновника наукової школи, професора Н.Й.Волошиної, у досягненнях 
науковців, що належать до створеною неї школі [101]. Додамо лише, що людські якості Ніли Йосипівни, іiі ставлення до науки, до людей, до життя в цілому, до кожного з нас були взірцем для всіх без винятку іiі вихованців, що значно підвищувало рівень наукової діяльності. Дійсно, коли тобі соромно, так би мовити, «падати в очах» твого наукового керівника або консультанта, працюєш зовсім по-іншому: iз наснагою, самовіддано, дбаєш не лише про захист дисертації, а насамперед про те, щоб виправдати довіру людини, яка є для тебе безперечним авторитетом не лише в науці, а й у житті.

Крім того, виникало стійке почуття належності до спільної справи, невипадково після уходу Ніли Йосипівни ми підтримуємо дружні стосунки, всебічно допомагаємо одне одному - саме цьому вона навчила нас. Яскравим прикладом такої - наукової та людської - взаємодопомоги можна вважати довготривалу історію із захистом докторської дисертації В. І. Шуляром, коли доктори наук, вихованці Ніли Йосипівни А. Л. Ситченко, С. О. Жила (офіційний опонент) та В. В. Гладишев взяли участь у засіданні вченої ради Херсонського державного університету, де було блискуче захищено дисертацію, науковим консультантом якої Василь Іванович, незважаючи на різні обставини, визначив саме професора Волошину. Ніхто з нас не вважав, що робимо щось незвичайне, просто допомагали одному 3 «своїх», людині, яка зберегла честь, порядність, мораль, вірність принципам, за якими жила Ніла Йосипівна.

Представники наукової школи Ніли Йосипівні тривалий час плідно працюють в усіх регіонах нашої країни, у багатьох школах, коледжах, університетах та інститутах. Кожному 3 нас дала «путівку у життя» людинанауковець, без якої ми були б зовсім іншими. Невипадково ми постійно підкреслюємо, що кожен, кому пощастило працювати з Нілою Йосипівною, вважає себе їі вихованцем. Зверніть увагу: не просто учнем, а саме вихованцем, оскільки вплив цієї людини на власне життя, на власну особистість розумієш лише згодом - коли виявляється, що наукові й людські принципи Ніли Йосипівні допомагають тобі у праці й житті. 


\section{PEDAGOGY IN MODERN CONDITIONS}

Переконані, що значення наукової школи Ніли Йосипівні Волошиної у методиці викладання літератури завжди було вагомим та, впевнені, буде зростати далі. Запорукою цього переконання $є$ те, що фундатором школи була непересічна Особистість, видатний Науковець, чесна, порядна, високоморальна Людина, яка прозорливо бачила труднощі та перспективи розвитку літературної освіти Україні, самовіддано працювала для того, щоб українські учні зростали кваліфікованими читачами і справжніми патріотами своєї країни. 


\section{SECTION 2. GENERAL AND PRE-SCHOOL PEDAGOGY}

\section{1 Інтегровані форми організації освітнього процесу в закладах дошкільної освіти}

Сучасний освітній процес характеризується інтегративністю, проблемноігровою спрямованістю, що, в свою чергу, зумовлює пошук таких форм організації освітнього процесу в закладах дошкільної освіти, які були б середовищем особистісного розвитку дитини та забезпечували б формування у дошкільників цілісної картини світу. Одним із ефективних шляхів розв'язання цього завдання $є$ побудова освітнього процесу на інтеграційних засадах.

Доцільність реалізації принципу інтеграції в дошкільній освіті науковці пояснюють синкретичною природою дитини дошкільного віку, яка у власному пізнанні світу «йде одночасно у різних напрямах» і має здатність до цілісного світосприймання за допомогою чутливих інформаційних каналів (О.Венгер, О.Дяченко, М.Поддьяков). Отже, потрібна така організація освітнього процесу в дошкільній освіті, у якій через інтегровані форми і види діяльності діти могли б знаходити прояви зв’язків між різними галузями знань і сферами життя.

У дошкільній педагогіці накопичено значний теоретичний і практичний матеріал з проблеми взаємозв'язку різних видів дитячої діяльності з позицій інтегрованого підходу (Г. Бєлєнької, А. Богуш, Н. Гавриш, І. Кіндрат, К.Крутій, О. Ліннік, Т. Піроженко та інші). Взаємозв’язок різних видів дитячої діяльності відображений у змісті різних видів занять, серед яких виділені інтегровані заняття (Н. Гавриш, Л. Горшунова, С. Козирєва, К. Крутій та інші). Аналіз останніх наукових досліджень і практики роботи педагогів закладів дошкільної освіти свідчить про стійкий інтерес до проблеми інтеграції в освіті.

Інтеграція - продумано вибудований процес навчання і виховання, який сприяє підготовці дітей до процесу сприйняття, розуміння і осмислення інформації, формування понять і уявлень про взаємодію всіх процесів у світі як єдине ціле. 
Реалізація принципу інтеграції передбачає організацію цілісного процесу. Цілісність створюється за рахунок синтезу, об'єднання різних елементів освітнього процесу в єдине ціле, таких як: різні види дитячої діяльності (ігрової, навчальної, художньої, рухової, дослідницької, трудової), різні види взаємодії (дитина-педагог, дитина-дитина, педагог-дитина-батько), різні освітні напрями i забезпечення єдиної лінії розвитку кожного дошкільника (фізичний, соціальноособистісний, художньо-естетичний, пізнавально-мовленнєвий).

Інтеграція освітнього процесу забезпечується за рахунок різних чинників. Чинником інтеграції може бути будь-який компонент змісту освіти або процесу, якісні характеристики його учасників. Першим і важливим чинником інтеграції у дошкільній освіті постають освітні лінії. Другим чинником є інтеграція освітніх ліній на основі календарно-тематичного планування: вибір певної теми визначає і підбір до неї освітніх ліній, які всебічно розкриють дитині їх зміст. Наступним чинником $є$ інтеграція основних видів діяльності дітей дошкільного віку: пізнавально-дослідницької, трудової, художньо-творчої, комунікативної, рухової. Діяльність як психологічна основа інтеграції здатна об'єднувати в собі розрізнені компоненти і бути інтегратором всіх інших діяльностей. Як четвертий чинник, можна виділити формування інтегральних якостей особистості як кінцевого результату освітньої діяльності ЗДО. П'ятим чинником інтеграції постає об’єднання форм навчання і виховання дошкільнят. Щоб якісно реалізувати принцип інтеграції в закладі дошкільної освіти, необхідно виділити форми інтеграції, які будуть забезпечувати і синтез освітніх ліній, і взаємозв'язок різних видів діяльності, і формування інтегральних якостей особистості дошкільника в процесі виховання, навчання й розвитку на основі календарнотематичного планування.

Форми інтеграційного процесу характеризують кінцевий продукт, який отримує нові функції, і нові взаємини педагога і вихованця, і навіть батьків протягом одного дня, тижня. Такими інтегрованими формами в закладі дошкільної освіти можуть виступати інтегровані заняття, спільні творчі проєкти, розвивальні ігри, експерименти, освітні подорожі тощо [102]. 
Інтегроване заняття об'єднує блоки знань із різних галузей (освітніх ліній/розділів програми) навколо однієї теми, що дає змогу пізнавати певне явище з різних сторін, досягати цілісності знань дітей. Такі заняття спрямовані на узагальнення і систематизацію знань дітей, збагачення їх життєвого досвіду, формування позитивно-емоційного ставлення до процесу пізнання, а тому вимагають практичних дій дошкільнят на занятті та активної розумової праці.

Структура інтегрованих занять потребує особливої чіткості, продуманого й логічного взаємозв'язку матеріалів з різних розділів програми на всіх етапах вивчення теми. Кількість запропонованих матеріалів, освітніх напрямів та видів роботи 3 дітьми обирає педагог. Залежно від того, які завдання $є$ головними, визначається той чи інший пріоритетний напрям, наприклад: художньоестетичний (музика, образотворче мистецтво), інтелектуально-мовленнєвий (ознайомлення з довкіллям, розв'язання комунікативних проблемних ситуацій), логіко-математичний, природничий тощо. На інтегрованому занятті неможливо відокремити одну галузь знань від іншої. Діяльність дітей має бути цілісною.

Кожен з методів (дидактична гра, вправа, бесіда, розглядання ілюстрацій, досліди, спостереження) чи видів діяльності необхідно організовувати згідно 3 методикою їх проведення в межах відповідного освітнього напряму.

Умовами ефективного проведення інтегрованих занять є: 1) висока професійна майстерність вихователя, що забезпечить творчу співпрацю з дітьми; 2) цілі заняття повинні відображувати його специфіку - інтегрованість; 3) включення попереднього досвіду дітей у навчальний процес; 4) продумане поєднання індивідуальних і групових форм роботи 3 дітьми, зміни видів діяльності; 5) прояв максимальної самостійності дітей у пізнавальній діяльності; 6) врахування вікових та індивідуальних особливостей дітей, їх творчих здібностей; 7) використання інтерактивних методів навчання; 8) активізація розумової діяльності дітей на всіх етапах заняття; 9) наявність варіативного дидактичного матеріалу, предметно-розвивального середовища.

3-поміж різних інтеграційних форм організації дитячої активності пріоритетною є проєктна діяльність. Вона спрямована на розв'язання проблеми, 
PEDAGOGY IN MODERN CONDITIONS

пов'язаної зі створенням освітнього продукту, що має суб'єктивну або об'єктивну цінність і може розглядатися як спосіб організації такої діяльності. Проєктна діяльність забезпечує інтегрований підхід в дошкільній освіті, оскільки вимагає обміркованого й обгрунтованого поєднання змісту з різних освітніх ліній БКДО, освітніх програм і видів діяльності дітей [103].

Проєктна діяльність заснована, з одного боку, на взаємодії з дорослими, а 3 іншого, що не менш важливо, - на основі постійного розширення самостійних дій дитини (власні проби, пошук, вибір, маніпулювання предметами і діями, конструювання, фантазування, спостереження-вивчення-дослідження). Саме проєктна діяльність дає змогу досягти високого рівня інтелектуальної, мовленнєвої, особистісної активності дошкільників.

Реалізація будь-якого проєкту здійснюється в ігровій формі, залученням дітей до різних видів творчої та практично значущої діяльності, в безпосередньому контакті з різними об’єктами соціального середовища (екскурсії, ігри, практично корисні справи). Так, наприклад, тема проєкту «Допоможемо птахам взимку» визначає вибір таких видів діяльності: пізнавально-дослідницької, художньо-творчої, продуктивної, ігрової).

Оскільки провідним видом діяльності дитини-дошкільника є гра, то, починаючи з молодшого дошкільного віку, використовуються рольові та творчі види проєктів: «Мої улюблені іграшки», «Умілі пальчики», «Тварини» та ін.

Дітям старшого дошкільного віку доцільно пропонувати різні види проєктів: дослідницькі: «Світ води», «Дихання і здоров’я», «Город на підвіконні», «Подорож насіння», «Лікарські рослини», «Що таке листопад?»; творчі: «Мої друзі», «Улюблені казки», «Хочу знати все про гудзик»; екологічні: «Наша річка Дніпро», «Хто забруднює повітря?», «Звідки береться папір?»; літературні: «Доброго дня, казко!», «Книжковий вернісаж» та ін.

Метою кожного проєкту $є$ вирішення проблемної ситуації, пошук відповідей на актуальні для дітей («Чому потрібно мити руки?») чи проблемні питання («Звідки хліб прийшов»), створення та презентація кінцевого продукту. Відповідно до природи дітей (та за наявності комфортного, вільного i 
креативного освітнього середовища) на завершальному етапі реалізації проєкту ними формуються нові проблемні особистісно-значущі запитання.

Реалізація будь-якого проєкту відбувається поетапно. На підготовчому етапі до iii проведення вихователь має зробити наступні кроки: 1) сформулювати проблему проєкту, сюжетно-ігрову ситуацію; 2) визначити мету, завдання та очікуванні результати проєкту; 3) продумати форму презентації проєкту (виставка, свято, гра-драматизація, сценарій казки, колекція, енциклопедія тощо); 4) розробити орієнтовний хід проєкту (продумати його варіативність); 5) розробити зміст занять, ігор, прогулянок, спостережень та інших видів діяльності, пов’язаних із темою проекту; 6) передбачити варіативність засобів, методів та прийомів роботи 3 дітьми.

Етап реалізації дітьми проєктної діяльності передбачає постановку проблеми у групі; іiі обговорення та визначення завдань; роботу над проєктом; презентацію продукту діяльності; аналіз ходу роботи над проєктом та постановку нової проблеми.

Інтегратором різних видів діяльності дитини є гра. В останні роки великої популярності набувають ігри-квести. Це форма активної взаємодії педагога i дітей, яка сприяє формуванню вмінь вирішувати ігрові пошукові завдання на основі компетентного вибору альтернативних варіантів через реалізацію певного сюжету. Така форма роботи поєднує у своїй структурі елементи мозкового штурму, тренінгу та гри. За допомогою квестів можна ознайомити дітей 3 новою інформацією, закріпити набуті знання, відпрацювати вміння.

Суть гри полягає в тому, що команди гравців, переміщуючись від зупинки до зупинки у реальному або віртуальному просторі, виконують завдання, об'єднані спільним сюжетом. Завдання для квесту можуть бути найрізноманітнішими: загадки, ребуси, дидактичні ігри, пазли, творчі завдання, лабіринти, спортивні естафети тощо. Особливість такої організації ігрової діяльності полягає в тому, що, виконавши певне завдання, діти отримують підказку до виконання наступного. Це мотивує їх до подальшого пізнання і дослідження. Виконавши всі завдання діти досягають мети. 
PEDAGOGY IN MODERN CONDITIONS

Проведення квесту відбувається поетапно. На підготовчому етапі вихователь визначає мету й завдання квесту; продумує сюжет і форму гри, пише сценарій; окреслює простір і добирає ресурси; визначає помічників та організаторів; узгоджує дату проведення; зацікавлює учасників. На початковому етапі - вихователь знайомить вихованців з тематикою, правилами квесту, обладнанням і матеріалами; створює команди (якщо квест проводиться як командне змагання) та розподіляє ролі між учасниками. Основний етап гри передбачає створення умов для виконання індивідуальної чи групової роботи дітьми відповідно до обраних ролей (розв'язання поставлених завдань). На заключному етапі підбиваються підсумки гри та нагороджуються переможці.

В ході реалізації квесту можна природним чином здійснювати інтеграцію освітніх ліній, комбінувати різні види дитячої діяльності і форми роботи 3 дітьми, вирішувати освітні завдання в спільній діяльності дорослого і дітей, самостійній діяльності дитини, активно взаємодіяти з родинами вихованців.

Аналізуючи результати проведеного дослідження зазначимо, що інтеграція як доцільне поєднання складників освітнього процесу у різних видах дитячої діяльності сприяє прояву ініціативи, самостійності, активності дітей, задоволенню їхніх потреб у самореалізації, забезпечує зв'язок з особистим досвідом дошкільнят, а також гармонійну взаємодію між дітьми та дорослим. У той же час, інтеграція потребує високої педагогічної майстерності педагога. 


\section{2 Сучасні проблеми дошкільної педагогіки: інклюзивна практика роботи дорослих 3 дітьми}

Філософія інклюзії відображає основні смисли спільного навчання, виховання і розвитку дітей в інклюзивних умовах закладу дошкільної освіти й грунтується на екологічній моделі теорії розвитку людини (The ecology of human development), розробленій Urie Bronfenbrenner (1917-2005) [103]. Провідна ідея екологічної теорії розвитку людини полягає в тому, що дитина поступово зростає у взаємопов'язаних системах (The Microsystem, The Mesosystem, The Exosystem, The Macrosystem and Human Development) [103], a процес іiі розвитку є результатом активної взаємодії між індивідом і його оточенням. Специфічний шлях розвитку окремої особистості розглядається як сумарний результат впливу оточення дитини (iї батьків, друзів, навчального закладу, освіти, культури, часу) на особистість. Екологічна модель розвитку людини, протиставлялась психології розвитку як науці про дивну поведінку дітей у дивних ситуаціях з дивними дорослими впродовж певних часових періодів.

Важливим для вихователя, який працює здітьми різних інклюзивних категорій, є розуміння потенціалу теоретичної екологічної системи розвитку людини. Розвиток дитини відбувається в межах інтегрованої системи: мікросистема, мезосистема, екосистема, макросистема та хроносистема, де кожен рівень системи впливає на наступний. У центрі моделі - дитина в оточенні мікросистеми, яка охоплює іï найближче коло (сім'я, заклад дошкільної освіти). Інклюзивна дошкільна група, у якій перебуває дитина, може бути прикладом мікросистеми, де наявні зв'язки між учасниками навчально-виховного процесу та дитиною з обмеженими можливостями. Наприклад, екосистема має опосередковані фактори впливу на дитину: соціальна та освітня політика позначається на створенні ресурсної бази дошкільної інклюзивної освіти, на додатковій спеціальній підготовці вихователів до роботи в інклюзивних умовах, на розширенні педагогічних досліджень уцій галузі та наданні сучасних рекомендацій для роботи з такими дітьми. Зміни, що відбуваються в освітній 
PEDAGOGY IN MODERN CONDITIONS

системі впродовж певного часу, відображаються в хроносистемі, де концептуалізуються провідні ідеї щодо створення більш ефективної системи дошкільної освіти в умовах інклюзії [104].

Для зрозуміння інклюзивної практики роботи дорослих 3 дітьми, ми використовуємо такі методи, як: текстологічний аналіз, систематизація й зіставлення експериментальних педагогічних, освітніх, ресурсних фактів у галузі дошкільної освіти.

Однією з цінних концепцій для суспільства є виховання і розвиток дитини на засадах задоволення фізичних, психологічних і освітніх потреб у соціумі; надання можливості кожній дитині якнайповніше розкрити свій потенціал в умовах дошкільної освіти [105].

Дослідники наголошують на необхідності забезпечення фізичних, фізіологічних і психологічних потреб, які $\epsilon$ взаємозалежними й взаємопов'язаними між собою, а саме: захист від фізичних травм, повноцінне харчування, використання одягу за сезонами та охайний і систематичний догляд за ним, регулярна профілактика соматичного здоров’я, створення умов для задоволення фізичних рухів іпідтримка активності в рухливих іграх; у психологічному плані - забезпечення довіри дитини до дорослого та іншої дитини, створення емоційної безпеки в родині, доброзичливе ставлення до особистості дитини, підтримка їі етнічного й мовного розвитку найближчим оточенням [105].

Непростим завданням для педагогів є зосередження уваги на конкретній проблематиці виховання і розвитку дитини, використовуючи інструменти спостереження за іï поведінкою, записи в педагогічних щоденниках і вміння оцінювати прогресивні зміни в розвитку дитини на підставі здійснення систематичного довготривалого аналізу [105].

Так, наприклад, на подолання проблем, пов'язаних з моторними вміннями дітей дошкільного віку, впливають різні підходи до підготовки вихователя, урахування його педагогічного досвіду в здійсненні індивідуалізації роботи, уміння надавати дитині, яка має фізичні порушення в розвитку, позитивну 
вербальну підтримку під час виконання нею фізичних вправ [106]. Щоб надати практичні рекомендації до покращення роботи вихователів 3 дітьми в галузі фізичного виховання, дослідники розробили експериментальні тренінгові двофазні програми: модель спостереження за моторними вміннями дітей із використанням словесних методів (перша фаза); тренінгова модель з використанням демонстрації вправ щодо формування моторних умінь (друга фаза) [106]. Модель спостереження вихователя за дітьми в застосуванні ними моторних умінь має свої переваги, серед яких: поєднання рефлексії зі спостереженням за дітьми, оцінювання якості виконання дитиною фізичних вправ, обговорення клінічного нагляду й аналіз джерельної бази порушеної проблеми. Тренінгова модель відображає зміни в поведінці вихователя під час роботи здітьми, сприяє розширенню професійного репертуару надання допомоги дітям у застосуванні ними моторних умінь [106].

Концептуальні рамки підготовки вихователя до інклюзивної практики в закладах дошкільної освіти охоплюють організаційно-змістовий контекст інклюзії в ранньому дитинстві, обговорення й аналіз індивідуалізованих моделей навчання і виховання дитини, що має порушення [107]. Науковці акцентують на необхідності здійснення високоякісної спеціальної підготовки вихователів до роботи з дітьми раннього віку з відхиленнями в розвитку: вихователі повинні розуміти як навчати й розвивати дитину з обмеженими можливостями, розуміти диференціацію різних моделей впливу на дитину, переходячи від сегрегованого середовища до всеохоплювального інтегрованого, а згодом- до створення інклюзивних умов у дошкільному закладі [107]. 3 огляду на це, потрібні зміни в переконаннях і педагогічних поглядах вихователів, кардинальні зміни ролей і обов'язків педагогів у контексті взаємодії з дітьми з особливими потребами в інклюзивних умовах. Опанування педагогами спеціалізованих інструкцій виховання і навчання дітей з фізичними, психологічними й освітніми порушеннями сприяє позитивним результатам і прогресивному просуванню дитини в соціумі. 
Дослідники експериментально вивчили вплив тренінгових моделей на підготовку вихователів до роботи в інклюзивних умовах 3 дітьми, що мають фізичні відхилення, і з дітьми без порушень фізичного розвитку [108]. Участь у дослідженні взяли вихователі з різним рівнем освіти (з дипломами про середню спеціальну освіту й дипломи бакалаврів мистецтв), стаж роботи яких становив від 5 до 27 років освітньої діяльності в закладах дошкільної освіти і які до експерименту не мали педагогічного досвіду роботи $з$ дошкільниками в інклюзивних умовах. Для створення й упровадження тренінгових моделей спеціальної підготовки дослідники спостерігали за дітьми та вихователями, на підставі чого було розроблено зміст трьох тренінгових моделей: С, В, А. Тренінгова модель (С) грунтувалась на використанні роздавального матеріалу й карток для навчання вихователів того, як подолати інклюзивні проблеми фізичного здоров'я у дітей. Тренінгова модель (В) засновувалась на лекційному циклі й була спрямована на зростання рівня теоретичних знань про дітей із фізичними відхиленнями й про педагогічні методи роботи з ними у сфері фізичного виховання. Наприкінці кожної лекції викладач з вихователями обговорювали лекційні питання. Тренінгова модель (А) передбачала спостереження за методичними прийомами роботи в дошкільній групі з дітьми, які мали фізичні відхилення в розвитку. У режимі реального часу вихователі спостерігали за діями експериментатора здітьми, які мають проблеми 3 фізичним здоров'ям. Дослідники дійшли висновку, що найвищі педагогічні результати показали вихователі, що навчалися за тренінговою моделлю $\mathrm{A}$, а найнижчі - за тренінговою моделлю $\mathrm{C}$, ті, хто навчався на роздавальному матеріалі [108].

Не менш вагомим у дослідженні є перцепція батьків на проблему дитини, що має відхилення в розвитку. Вихователеві необхідно розуміти ставлення батьків до своїх дітей з особливими потребами, порівнювати зі ставленням батьків до дітей без особливих потреб; розуміти сутність батьківських уявлень, рівень їхньої обізнаності з психолого-педагогічною проблемою, яку має їхня дитина. Таке розуміння перцепції батьків є важливим для вихователя, який 
PEDAGOGY IN MODERN CONDITIONS

ставить собі за мету надання психолого-педагогічної допомоги дітям з відхиленнями в розвитку та їхнім родинам.

На переконання дослідників [109], необхідно ретельно систематизувати дані про етнічні групи, умови життя дошкільників, виховання дітей у родинах. Для цього розроблено анкети, питання для проведення інтерв’ю $з$ педагогічним персоналом, проаналізовано зміст дошкільних програм виховання дітей і практика виховання в закладах дошкільної освіти (Preschool 1, Preschool 2, Preschool 3, Preschool 4). Так, наприклад, кожен опис дошкільних закладів з чотирьох, презентованих у дослідженні, містив: питання щодо організації керівництва дошкільним закладом; аналіз складу педагогічного персоналу, який виховує дітей дошкільного віку, та бесід з вихователями з питань інклюзії; аналіз різних типів особливостей і обмежень у розвитку дитини та їх характеристики (the types of disabilities); розв’язання проблем на підставі виконання завдань дошкільних програм; кількісний склад дітей у дошкільному закладі, які потребують допомоги; особливості педагогічної діяльності персоналу, спрямованої на виконання основних завдань дошкільної програми. Наведемо приклади кількісного та якісного аналізу дошкільних закладів (Preschool 1), що відображають їх розташування у великому об’єднаному шкільному окрузі на території шкільного кампуса на Півдні Каліфорніі. За етнічним складом там проживають 57,5\% латиноамериканців, 20,8\% афроамериканців і 16,0\% білих (57,5\% Hispanic, 20,8\% African American, and 16\% White).

Preschool 1 має свій сайт для педагогів 3 таких питань, як: експертні знання в галузі розробки критеріїв оцінки інклюзивної проблеми, аутизм, інклюзія, лідерство, природне середовище, робота з батьками та професійний розвиток персоналу (expertise in assessment, autism, inclusion, leadership, natural environments, parent involvement and professional development). 3 координатором програми, який займався адміністративною роботою протягом 15 років і працював у цьому дошкільному закладі впродовж 3-х років, було проведено інтерв’ю (01.07.2009), у якому він схарактеризував соціально-економічний статус батьків, а також проаналізував мовні проблеми дітей дошкільного віку, 
PEDAGOGY IN MODERN CONDITIONS

серед яких 75\% мають стосунок до спеціальної освіти (зір, слух), 10-15\% - діти зі значними відставаннями в розвитку мови (англійська). Координатор з двома асистентами-помічниками, які підтримують адміністрування сайту, забезпечує багатопланову роботу: працюють спеціалісти з освіти, тренери, логопеди, трудотерапевти, фізичні терапевти, аналітики прикладної поведінки, педагоги, які займаються зі слабкозорими, туговухими й глухими дітьми.

Дослідники підкреслюють, що в суспільстві більше звертають увагу на порушення мови, ортопедичні проблеми дитини, а найменше - на емоційні та когнітивні порушення, дитячий аутизм [109, 110].

Отже, аудиторія з інклюзивними категоріями дітей повинна мати кваліфікований педагогічний персонал, спеціально підготовлений до роботи в умовах закладу дошкільної освіти. Інклюзія - це не просто гарна ідея, а насамперед трансформація освітнього середовища для дітей, де вчасно задовольняються фізичні, психологічні, освітні, комунікаційні потреби кожної дитини загалом і дитини з обмеженими можливостями зокрема. Різноманітне ставлення до проблем інклюзії залежить від спеціальної підготовки вихователів, від батьків і суспільства. Соціальні, освітні та етнічні фактори чинять істотний вплив на педагогічний колектив дошкільного закладу, який має виробити практичні вміння працювати з різними інклюзивними категоріями дітей, що мають ортопедичні, мовні, когнітивні, емоційні, психологічні порушення, а також з їхніми батьками. На сьогодні вже розроблено правові, раціональні, емпіричні й теоретичні засади залучення дітей дошкільного віку з обмеженими можливостями до типових програм розвитку дітей в умовах звичайного дошкільного закладу на засадах інклюзії. 


\section{1 Історико-педагогічні аспекти інституційних перетворень у вищій школі США}

Протягом останніх років структура та зміст вищої освіти в нашій країні зазнали значних змін, що є наслідком інтеграції національної освітньої системи в європейський освітній простір. Реформування системи освіти в усіх ії ланках необхідно. Передусім це стосується вищої освіти, яка має забезпечити суспільство висококваліфікованими спеціалістами в різних галузях.

Вища освіта у Сполучених Штатах почала зазнавати серйозних змін у період з 1860-х до 1910-х рр. Головним чином це пов'язують 3 діяльністю ректора Прінстонського університету В. Уілсона (1902- 1910) і ректора Гарварда Л. Лоуелла (1909-1933).

Прибічники реформ у вищій освіті США погоджувалися з Уілсоном, який уважав, що навчання у коледжі повинно допомогати студенту розвиватись інтелектуально й духовно. У цьому зв'язку дуже важливу роль відігравали взаємовідносини студентів та викладачів, які повинні були перейти на якісно новий рівень. Викладач мав не лише формально консультувати студентів у процесі навчання, а й у неформальній обстановці, наскільки це можливо, ділитися своїм життєвим досвідом зі студентами, зацікавити їх своїм предметом.

Причиною відсутності тісного контакту між студентом і викладачем в аудиторіях американських університетів уважається вплив німецької вищої освіти. Вчені - представники цієї школи «відчували огиду до процесу викладання й дивилися на студентів як на певну перешкоду»[121]. Прогресивні викладачі відчували, що кожний студент коледжу «повинен мати принаймні одного товариша серед викладачів, того, хто буде спостерігати за його навчанням, буде знати про сімейні обставини, про те, як студент навчається, які в нього перспективи, здібності та недоліки»(там само).

Починаючи 3 кінця 1890-х років, Кембридж і особливо Оксфорд стали прикладами того, що подібний викладач-товариш може існувати. Кожний 
студент прикріплювався до тьютора, який надавав індивідуальні консультації під час регулярних щотижневих зустрічей. Крім того, студентам пропонували за прочитаним і вивченим матеріалом писати реферати, які обговорювались під час тьюторських занять. Поза тьюторськими заняттями студенти й викладачі мали змогу зустрічатись і спілкуватись у менш формальній обстановці завдяки тому, що більшість викладачів мешкали на території коледжів.

Джон Корбін, а слід за ним Френк Боулес, посилаючись на досвід англійських колег, уважали, що студентів необхідно розподілити на невеликі групи, кожна з яких буде під наглядом викладача-консультанта[113].

Президент Свартморського коледжу з 1921 до 1940 р. Френк Айделоут був одним із прибічників упровадження в американські університети англійської системи тьюторства. Починаючи з 1910 року, ще працюючи викладачем англійської мови в Індіанському університеті, він написав низку статей, у яких із захопленням характеризував систему викладання в Оксфорді. Основний акцент Айделоут робив на відповідальність кожного студента за самоосвіту з активною допомогою тьютора[111].

Простежити зміни в системі вищої освіти в США в кінці 19 на початку 20 віків можна на прикладі найбільшого американського вищого навчального закладу - Гарвардського університету. Наприклад, Едвін Слоссон зазначав, що студенти потребують більшої уваги з боку викладачів і особливо тих, хто офіційно призначений порадниками. «У Гарварді, - писав він,- порадник повинен познайомити першокурсників із їхніми обов'язками, допомогти адаптуватися в університеті,але насправді ці зустрічі були чисто формальні і не більш персональні, ніж надання інформації про розклад поїздів на вокзалі» [121].

У 1904 році випускник Гарварду Джон Фогг Туомблі запропонував приз студентам середніх і старших курсів університету за три найкращих ессе на тему «Можливість і необхідність впровадження сучасних програм і методів навчання англійських коледжів у наші великі університети, особливо в Гарвард». Ессе Генрі Путнема Пратта, що було визнано найкращим, надруковане в журналі «Harvard Graduate's Magazine» разом із коментарем Туомблі. Обидва автори 
зазначали необхідність реорганізації університету, що вимагали розділити коледж на шість «холів», у кожному з яких мешкало б близько двохсот студентів і шість тьюторів, обраних із викладацького складу університету. Передбачалося, що поділ на «холи» буде відбуватися з урахуванням академічних інтересів студентів i, отже, тьютори будуть обиратися залежно від предметів, які вони викладають. Студент кожного тижня буде відвідувати близько десяти лекцій професорів університету й шість-вісім конференцій чи «секційних зустрічей» у «холі», що проводитиме тьютор [122].

Ректор Прінстонського університету з 1902 до 1910 р. В.Уілсон зазначав, що в навчанні важливу роль відіграє самоосвіта. Він наголошував, що студенти повинні здобувати знання самостійно, а викладач повинен виступати в ролі порадника. Таким чином, процес навчання - це «інтелектуальне спілкування менш досвідченої особи з більш досвідченим товаришем із метою отримати знання» [118].

В. Уілсон згадував, що ідея реформувати Прінстонський університет 3’явилась у нього ще у 1897 році після відвідання Оксфорда [112]. Серйозних змін зазнав, по-перше, навчальний план. По-друге, важливим пунктом реформ стало удосконалення тьюторського плану, названого системою наставництва.

Система наставництва у Прінстоні була удосконаленою формою Окфордської тьюторської системи, метою якої було «введення у великі університети методів навчання й безпосереднього особистого спілкування викладачів і студентів невеликих коледжів» [117].

Впровадження такої системи вимагало введення у професорськовикладацький склад нової посади - викладача-наставника. Головним обов’ язком наставника було зацікавити студентів безпосереднім «індивідуальним інтелектуальним спілкуванням із викладачем» на зразок того, що В. Уілсон спостерігав у Оксфорді. Згідно плану, студенти середніх та старших курсів кожного тижня зустрічалися 3 наставником на тьюторських заняттях, метою яких було обговорення самостійно опрацьованої додаткової літератури на тему прослуханих лекцій. Уілсон відзначав, що наставниками можуть працювати ті 
PEDAGOGY IN MODERN CONDITIONS

викладачі, які мають репутацію джентльменів, зарекомендували себе товариськими особами, чиї персональні вміння спілкуватись допоможуть їм впливати на інтелектуальний розвиток молодих людей.

Наріжним каменем у проведенні цієї реформи стала відсутність коштів, але Уілсон зміг переконати меценатів,і в 1905 році вони офіційно затвердили посаду наставника. Сорок п’ять викладачів обійняли цю посаду, двадцять 3 яких уже працювали у Прінстоні, а інші перейшли з інших навчальних закладів. Тридцять сім наставників мали ступені докторів наук. Ці зміни переконали В. Уілсона в тому, що безпосередній контакт між молодими людьми й досвідченішими товаришами має важливе значення у процесі навчання.

Система наставництва існувала у Прінстоні й після того, як Уілсон залишив посаду ректора в 1910 році. Але вже в 1908 році Авраам Флекснер висловлював сумніви щодо цієї системи, які з часом підтвердились [115]. Наставники були обтяжені читанням багатьох курсів, і в них ледь вистачало часу на безпосереднє індивідуальне спілкування зі студентами. Система, отже, не сприяла розвиткові індивідуального навчання, що вважалось основною метою. I вже в 1925 році посада наставника була скасована в університеті. Але реформи у Прінстоні мали важливе значення для впровадження посади тьютора у вищі навчальні заклади в майбутньому.Реформи в Гарвардському університеті пов'язують 3 ім’ям Л. Лоуелла, а план реформ, затверджений у 1929 році, називають «Прінстонським планом, впровадженим у Гарвард на гроші Сльського університету» [120].

Лоуелл наполягав на системі тьюторського інструктування, оскільки вона передбачала стимулювання розумової активності «апатичних студентів Гарварда» i, отже, значне підвищення рівня їхніх знань.

3 ініціативи ректора історичний, суспільний та економічний факультети в 1912 році впровадили підсумкові загальні екзамени й тьюторську систему. Починаючи $з$ другого курсу, кожний студент був закріплений за тьютором 3 профілюючої дисципліни. Цей тьютор працював зі студентом до останнього курсу, готуючи його до складання іспиту. 31919 до 1924 року всі факультети, 
крім хімічного та технічного, впровадили підсумкові екзамени й тьюторське інструктуваня.

Сама структура факультетів американського університету перешкоджала копіюванню оксбриджської моделі спілкування між студентом і викладачем. Призначення тьюторів, цінність системи тьюторського інструктування на різних факультетах були різними. На деяких факультетах тьюторами призначали студентів старших курсів, на інших - усі викладачі виконували обов'язки інструкторів; дехто вважав тьюторську систему основною формою навчання, інші не надавали їй такої важливості. Незважаючи на те, що Лоуелл намагався створити «оксбриджський ідеал в американському університеті», студенти Гарварда часто стикалися «з недоосвідченими і нецікавими тьюторами» [116].

Деякі викладачі Гарвардського університету робили спроби порадитися 3 колегами в Оксфорді щодо «механізмів роботи тьюторської системи». У 1924 р. після того як англійський факультет Гарварда вирішив впровадити тьюторську систему, двоє викладачів університету були направлені в Оксфорд для вивчення цієї системи в дії. Але вони змогли відвідати англійський університет лише влітку і тому не мали змоги спостерігати в повній мірі тьюторську систему в дії. Перкінс, описуючи цей візит, відзначав, що тьютори Оксфорда були здивовані цілями тьюторського плану в Гарварді. За Перкінсом, «американська концепція тьюторства сильно відрізнялась від англійської» [119]. Подібні критичні зауваження щодо тьюторства в Оксбриджі 20-х рр. зробив Джеймс Роланд Анджел. У 1921 році він став президентом Сльського коледжу, і саме йому належить ідея «неформального контакту між студентом i викладачами університету» і впровадження тьюторської системи [110].

3 метою вивчення досвіду англійських колег у 1927 році Анджелл відвідав Оксфорд, Кембридж та інші англійські університети. Він спостерігав стосунки між студентами й наставниками і зробив висновок, що «вони зводяться лише до проживання в одному коледжі й вечері за одним столом» [120]. На думку Анджелла, наставник повинен бути «цікавою особистістю з організаторськими 


\section{PEDAGOGY IN MODERN CONDITIONS}

здібностями, з умінням і бажанням передавати свій досвід молоді, справжнім учителем...» [110].

Протягом 30-х - 70-х рр. тьюторська система в Гарварді не була настільки результативною, як це передбачалось. Алекс Дьюк зазначає, що основною причиною цього стало те, що посади тьюторів, у основному, обіймали старшокурсники. Крім того, самі студенти не вважали роботу з тьюторами основним у навчанні, адже була дуже незначна кількість справді кваліфікованих тьюторів [114]. Пізніше, у 60-ті - 70-ті рр., в університеті Санта-Круз також були спроби впровадити тьюторську систему. Але тьюторські групи були досить великі для подібного виду навчання, і що не менш важливе, мало хто знав, як проводити подібні заняття.

Таким чином, впровадження Оксбриджської моделі навчання в американські університети зазнало поразки, хоча значно впливало на розвиток i формування системи вищої освіти в США. Американський тьютор - це найчастіше старшокурсник чи молодий викладач, у обов'язки якого входить консультація студента щодо вивчення певних предметів і організації навчання в університеті. Тьюторство не стало основним компонентом вищої освіти в США. Вивчення змісту, форм роботи тьютора в американських університетах дозволяє адаптувати позитивний досвід організації тьюторської діяльності в закладах освіти України. Саме ці питання мають бути перспективними у подальших дослідженнях. 


\section{2 Українські наротиви С.С. Прокоф'сва}

Ім’я Сергія Сергійовича Прокоф'єва добре відоме всьому світу. Життєвий шлях цього неперевершеного майстра тісно пов'язаний з багатьма країнами світу: Росією, США, Францією, Німеччиною, де його творчі доробки не залишали байдужими музичні кола. Звичним є називати С. С. Прокоф'єва російським композитором і така думка має право на існування. Проте, сам композитор дуже часто ідентифікував себе не росіянином, а народженим в Україні.

Метою статті є визначити, який вплив мала його «мала батьківщина» на формування митця, яке місце займала Україна у його серці.

Народився Сергій Прокоф’єв в Україні, про що ніколи не забував і чим пишався. Як сприймав С. Прокоф'єв свою малу батьківщину, найкраще відповів сам композитор далекого 1918 року, плануючи свою поїздку до Північної Америки, де зазначив: «Може бути, що американці й дивитися не побажають на російських сепаратистів, але ж я уродженець лояльної Украйни..». Тобто, він чітко відрізняв тих, хто проживають на території Росії та етнічної України і ставлення до них було неоднозначним..

Сергій Сергійович називав себе «степовим хлопчиком», який народився «на великих степових просторах» у селі Сонцівка. «Мені вона доводиться батьківщиною моєю», - писав він у Автобіографії й уточнював: «Маєток Сонцова, поверхнею в 6 тис. із гаком гектарів знаходився в Катерининській губернії Бахмутського повіту» (нині це село Сонцівка Покровського району Донецької області). У Сонцівці, яку Сергій Прокоф’єв нестямно любив, він провів свої перші 13 років. «Коли я лише на пів-зими виїжджав із Сонцівки, я ледь не плакав, настільки моє дитяче життя було повязано з цим куточком»[122], - згадував композитор.

Бунтівний характер композитора формувався під впливом духів зі скіфських курганів, архаїки українських степів, історичних міфів. «Кольорові килими чергувались із зеленими полями пшениці. Іноді траплялися невисокі кургани, 
пам'ятники степових кочівників. У них, бувало, знаходилося начиння i старовинні монети»[123], - згадував С. Прокоф'єв. На скіфських рівнинах височіли залишки курганів-поховань і стояли ідоли кочівників. Яскраві картини степових просторів, що таїли в собі пам'ять найдавнішої культури, закарбувались у музиці композитора. Образи балету «Ала і Лоллій» і створеної на його основі симфонічної «Скіфської сюїти» відроджували язичницькі сюжети скіфської міфології. Після скандально успішної прем’єри «Скіфської сюїти» в Петербурзі, якою диригував сам автор (29 січня 1916 р.), переважна частина публіки була обурена «диким твором», як писав один із критиків. Тим самим рецензент наче уточнив джерело музичних образів Сюїти, навіяних скіфськими просторами Дикого поля. Перебуваючи довгі роки за кордоном, Прокоф'єв не раз висловлювався своїм друзям про мрію жити і творити в «рідному ландшафті»[124].

Із Україною Прокоф'єва пов’язує не тільки його рідна Сонцівка. Окрім її околиць, бував він у Києві, Харкові, Одесі, Нікополі. У Києві відбулися його перші концерти, організовані 1916 р. Р. Глієром, який з'являвся в житті С. Прокоф'єва епізодично на два літа в 1902 і 1903 роках (як репетитор молодий Глієр займався з Прокоф'євим фортепіано, імпровізацією, теорією композиції, гармонією, а також допоміг написати оперу «Бенкет під час чуми»), та залишив глибоке добре враження і дружбу на все життя. С Прокоф'єв вважав Р. Глієра найвидатнішим педагогом i зазначав, що в більшості композиторів, кого зустрічав Сергій Сергійович - всі були чи прямими чи то внучатим його учнями [125].

Зустріч із Києвом надихнула Сергія Сергійовича на поетичний піднесений, наповнений семантикою здоров'я і бадьорістю експромт:

«Не утомившися в вояже

Вступил на почву града Кия.

Как здесь светло! Лучи какие!

И облаков немного даже!»[126]. 
Саме в Києві С. Прокоф’єв здобув перше в Україні визнання як композитор і виконавець, але й зіткнувся 3 нерозумінням і неприйняттям своєї музики. Більшість сприймала його як «музичного варвара і руйнівника традиційних устоїв». «Рідкісний нахаба, завзятий футурист», - такими епітетами нагородили молодого композитора в музичних колах Києва [122]. У ті дні Прокоф’єв грав для студентів Київської консерваторії. Приїзд композитора виявився значною подією в житті міста, а навколо його музики велися гарячі суперечки, що утворили два протилежні табори. Один із найавторитетніших музикантів Києва, професор Київської консерваторії Володимир Пухальський, сприйняв С. Прокоф'єва як «глибоко своєрідного композитора, 3 дуже яскравою i самобутньою індивідуальністю» і пророкував йому велике майбутнє. На думку професора, «композитор зробив стрибок з XVIII в XX сторіччя...».

1927 року, під час тріумфальних гастролей Сергія Прокоф’єва після восьми років перебування за кордоном, концерти його симфонічної та камерної музики проходили з величезним успіхом також у Києві, Одесі та Харкові. 1934 року гастрольний маршрут музиканта теж включав Одесу та Київ. Тоді ж, у Києві, Прокоф'єв передав свою фотографію з дарчим написом: «Бібліотеці Академії Наук у Києві. СПРКФ.1934» (саме так підписувався композитор). До свого подарунку він додав рукопис фрагмента з Першого квартету.

Спогади про землю, де народився Прокоф'єв, і музику, яку він чув, луною відгукнулися також у балеті «На Дніпрі», який було поставлено в Парижі в театрі Гранд-опера (16 грудня 1932 р.) видатним хореографом, українцем за походженням, Сержем Лифарем. Примітно, що в паризькій постановці Дніпро було перейменовано на свою давню назву - Борисфен.

1939-го С. Прокоф’єв створив оперу «Семен Котко» по повісті В. Катаєва «Я син трудового народу», музика якої теж зігріта теплом спогадів про степові простори та їхні дзвінкі народні пісні. Опера, попри, здавалось, більшовицьку тематику, містить сумний мотив дисонансного трагічного українського середовища в умовах радянської окупаційної влади. 
PEDAGOGY IN MODERN CONDITIONS

В лібрето опери не тільки збережені, а й посилені гоголівсько-барокова поетика та епічний масштаб оповідання, властиві катаєвському тексту, про що свідчить кульмінаційна сцена четвертого акту - похорон Царьова і Івасюка, загиблих від рук загарбників. Вони супроводжуються масштабним вокальним номером - хором партизан на слова «Заповіту» Т. Шевченка в перекладі Н. Тихонова. Цей хор носить піднесено-трагічний характер. Ймовірно, що питання про включення «Заповіту» в оперу у 1938-39 роках, у розпал сталінських репресій було простим.

Йому передує клятва-монолог Ременюка, голови сільської ради і командира партизанського загону, який є традиційним набором мовних фігур ритуального прощання і обіцянок народного гніву: «... прийде час - народ встане. Як одна людина він встане, і помста його буде жахлива. Повстанці, клянуся!».

I хоча партизани, клянучись іменем Леніна, демонструють в стані екстатичного гніву свою лояльність більшовицькому режимові, відстоюють вони все-таки незалежність України. Це доводить і словесний рефрен в розгорнутому фінальному номері третього акту (жіночий хор і солісти): «Пропала наша Україна, все пропало!».

Він смислово римується і з текстом пісні бандуриста на самому початку п'ятого акту:

«Чорний, гіркий дим піднявся

Над рідною Україною».

Образ бандуриста в лібрето, (відсутній в катаївській повісті) абсолютно виправдано загальним національно-епічним пафосом, на зміцнення якого працює і сам жанр виконуваної думи - одного з традиційних музично-поетичних жанрів художньої культури України.

У лібрето опери, як і в початковому тексті, виявляється велика кількість українізмів. Наприклад, «ще», «бо» («тому що»), «ратуйте» («рятуйте»), «не журись» і т.д. При цьому С. Прокоф'євим вміло використовується фольклорний ресурс з метою характеристики окремого персонажа. Так, музичний образ Фросі, цікавої і жвавої дівчини, маркується українською народною піснею: 


\section{PEDAGOGY IN MODERN CONDITIONS}

«I шумить, і гуде, дрібний дощик іде,

А хто ж мене молоду, та й додому відведе?».

С. Прокоф'євим врівноважується жанрово-етнографічне та національноепічне, завдяки чому і встановлюється і підтримується оптимальний музичнодраматичний баланс. В оперному лібрето збережено етнографічна точність у відтворенні народних обрядів і ритуалів народного життя.

На українську тему композитор пише музику до кінофільму Ігоря Савченка «Партизани в степах України» (1942р.), де використовує тексти українською мовою, а мелодика перейнята інтонаціями українського фольклору. Та фільм виробництва Київської кіностудії на екран не вийшов. Тоді ж Сергій Прокоф’єв створив музику до кінострічки М. Мордвіна «Котовський» - «про героя боротьби 3 німецькою окупацією Україну в 1918 році» (коментар самого композитора) [127]. Провідна музична тема цієї стрічки заснована на мелодії української пісні «Ой ти, Галю».

Один із своїх романсів С. Прокоф'єв присвятив землі, де народився, й там є такі слова:

«Золотая Украина - край мой хлебородный.

За тебя немало крови пролито народной!»

Своє ставлення до радянського режиму Сергій Прокоф'єв проявив у Кантаті до 20-річчя Жовтня - творі, де неможливо відділити пафос від іронії. Побудувати кантату, яка мала б виконуватися під час масових заходів на Червоній площі за структурою католицької меси, включити туди цитати з «Ночі на Лисій горі» Мусоргського (фактично, картину шабашу) та перетворити тексти Маркса, Леніна і Сталіна на незрозумілий фарш із музичної м'ясорубки - таке міг зробити тільки хуліган Прокоф’єв.

Незважаючи на російське коріння, освіту і мову Прокоф’єва - Україна завжди залишалась в душі композитора. «Скіфська сюїта», що навіяна степовими пейзажами Дикого поля, балет «На Дніпрі» для театру «Гранд-Опера» (у французькій постановці - «Борисфен»), хор «Золота Україна», донбаський сюжет «Семена Котка»- лише частина творів, тематично пов’язаних з Україною. 


\section{PEDAGOGY IN MODERN CONDITIONS}

Зі свого 61 року - 13 він прожив на Донеччині (щороку повертаючись сюди на канікули до повноліття), ще 18 - в еміграції. У Росії - царській і радянській трохи менше половини життя. Говорив і писав російською, але подекуди замінював на письмі, часто в своїх листах російське «и» українським «і», назву села Прокоф'єв зберігав в українській орфографії, і пам’ятав донбаський суржик. Навіть говорячи про очевидні українські впливи на його творчість - і у вигляді фольклорних запозичень, і у виборі тем і сюжетів - С. Прокоф’єв був українським композитором. Бути народженим та до 13 років жити на Донеччині, називати себе «степним хлопчиком» та «уродженцем України», шукати в еміграції «рідний ландшафт» і постійно звертатися у творчості до української теми - цього достатньо для того, аби відчути що Прокоф'єв пишався своєю причетністю до України.

Україна також пишається своїм сином: ім'я Прокоф'єва носив аеропорт Донецька, оборону якого тримали протягом 242 днів герої-кіборги.

1991 р. ЮНЕСКО оголосив роком Прокоф’єва, а 2011 рік в Україні був оголошений роком Прокоф’єва. 


\section{3 Національна система освіти України: типи закладів освіти та динаміка їх розвитку}

Освіта - основа інтелектуального, культурного, духовного, соціального, економічного розвитку суспільства і держави. Метою освіти $є$ всебічний розвиток людини як особистості та найвищої цінності суспільства, розвиток іiі талантів, розумових і фізичних здібностей, виховання високих моральних якостей, підвищення освітнього рівня народу, забезпечення народного господарства кваліфікованими фахівцями.

Система освіти як сукупність навчально-виховних закладів систематично і послідовно здійснює виховання, навчання і підготовку до життя підростаючих поколінь відповідно до завдань суспільства. Освітній сектор є стратегічно важливою сферою розвитку держави, він має забезпечувати такий рівень розвитку людського капіталу, який буде відповідати потребам і викликам постіндустріального суспільства побудованих на наукомістких технологіях.

Освітня система України сьогодні - це 7.7 млн. тих, хто навчається і 1,5 млн. тих, хто навчає й забезпечує процес навчання. Отже, майже 20\% населення країни безпосередньо пов'язані з освітою, а якщо додати сюди членів родин, ця цифра зросте щонайменше вдвічі [131].

Функціонування системи освіти забезпечується державою. У статті 53 Конституції України зазначено: «Держава забезпечує доступність і безоплатність дошкільної, повної загальної середньої, професійно-технічної, вищої освіти в державних і комунальних навчальних закладах; розвиток дошкільної повної загальної середньої, позашкільної, професійно-технічної, вищої і післядипломної освіти різних форм навчання; надання державних стипендій та пільг учням і студентам» [132]. Закон України «Про освіту» (ст. 3) гарантує громадянам України право на безкоштовну освіту в усіх державних навчальних закладах незалежно від раси, національності, соціального стану, роду i характеру занять, світоглядних переконань, належності до партій, ставлення до релігії, стану здоров’я, місця проживання та інших обставин [131]. Розглянемо детальніше основні складові даної системи та етапи їх розвитку. 


\section{PEDAGOGY IN MODERN CONDITIONS}

До 1918 року в Україні існувала система формальної та матеріальної освіти. У межах формальної системи вивчалися предмети, які не завжди мали практичне значення, спиралися на механічне запам'ятовування матеріалу.

До нижчого рівня формальної системи належали сільські, земські або церковно-парафіяльні школи, де навчали дітей (у межах 2-3 класів) письма, лічби, читання, Закону Божого. На середньому рівні формальній освіті відповідали гімназії в містах, які готували службовців, чиновників або абітурієнтів до вступу у вищі чи середні навчальні заклади. До вищого рівня належали університети, які надавали переважно гуманітарну освіту.

Матеріальну освіту отримували в реальних (спеціально для виробництва) i в комерційних (купці, економісти) училищах, технікумах, політехнічних інститутах. Існували також у незначний кількості духовні та учительські семінарії.

У 1919 році згідно із "Положенням про єдину трудову школу УРСР", більшовики проголошують комуни, що передбачало: безплатне і спільне навчання дітей обох статей 3 8-ми років, загальноосвітній і політехнічний характер навчання, заборону релігійного виховання, введення в школі продуктивної праці дітей. Скасовувались екзамени, домашні завдання, 5-бальна система оцінювання, класи поділялись на групи за рівнем підготовленості.

У 30-х роках XX ст. експерименти вчителів були розкритиковані й заборонені. Вийшло кілька постанов про відновлення у школі класно-урочної системи, предметний поділ викладання змісту освіти, про гімназії, пільги вчителям, обов'язки класного керівника. Система народної освіти того часу становила: дошкільні заклади (для дітей $3-8$ років - це садочки і майданчики), школа I ступеня (8-12 років), школа II ступеня (12-15 років), а також ФЗУ (учнівство) та технікуми. Із 1930 р. запроваджувалося обов'язкове початкове навчання, а 3 1934-1935 рр. - семирічне, розвивалися середні школи, профтехучилища, технікуми в містах i райцентрах, удосконалювалось управління — з'явилося Міністерство Освіти України. 
На сучасному етапі, з прийняттям Закону "Про освіту" (1996 р.) до вищих навчальних закладів віднесено коледжі, технікуми, училища (педагогічні, музичні, культурно-освітні); середню спеціальну освіту ліквідовано, тобто зроблено крок до світових стандартів. Згідно із Законом "Про освіту" система освіти в Україні поєднує: дошкільне виховання, загальну середню освіту, професійну освіту, вишу освіту, післядипломну підготовку, аспірантуру, докторантуру, підвищення кваліфікації, перепідготовку, позашкільне навчання і виховання, самоосвіту [133].

Дошкільна освіта. Важливе місце в системі безперервної освіти в Україні належить дошкільній освіті. Законодавство України визнає дошкільну освіту первинним елементом загальної структури освіти в державі. Питання функціонування дошкільних навчальних закладів урегульовано Законом України «Про дошкільну освіту», Положенням про дошкільний навчальний заклад.

Дошкільними закладами освіти є: дитячі ясла, дитячі садки, дитячі ясласадки, сімейні, прогулянкові, дошкільні заклади компенсуючого (для дітей, які потребують корекції фізичного і психічного розвитку) та комбінованого типів 3 короткотривалим, денним, цілодобовим перебуванням дітей, а також дитячі садки інтернатного типу, дитячі будинки, центри розвитку дитини, дитячі будинки сімейного типу та інші.

Що ж стосується структури дошкільних закладів за формою власності, то переважна більшість їх перебуває у комунальній (59\%) та колективній (32\%) власності. Державою фінансується 7\% закладів, у приватній формі власності перебуває лише $2 \%$ загальної кількості дошкільних установ [131].

Загальна середня освіта. Загальноосвітня школа — базова ланка в системі неперервної освіти громадян України. Вона забезпечує всебічний розвиток дитини як особистості, іiі нахилів, здібностей, талантів, трудову підготовку, професійне самовизначення, формування загальнолюдської моралі, засвоєння визначеного суспільними, національно-культурними потребами обсягу знань про природу, людину, суспільство і виробництво, екологічне виховання, фізичне 


\section{PEDAGOGY IN MODERN CONDITIONS}

вдосконалення. Загальноосвітня школа дає якісну середню освіту і можливість свідомо вибрати вищий навчальний заклад, технікум чи ПТНЗ або здобути професію на виробництві.

У законі «Про освіту», «Положенні про середній загальноосвітній навчально-виховний заклад» йдеться про триступеневу школу [133], і відповідно до цього функціонують загальноосвітні навчальні заклади I ступеня (початкова школа - 3 роки); II ступеня (основна школа - 5 років); III ступеня (старша школа - 2-3 роки). Загальноосвітні навчальні заклади всіх трьох ступенів можуть функціювати інтегровано або самостійно.

Мережу загальної середньої освіти складають заклади всіх типів і форм власності, у т.ч. для розвитку здібностей дітей функціюють спеціалізовані школи, колегіуми, а також різні типи навчально-виховних комплексів; для дітей, які потребують корекції фізичного та/або розумового розвитку, створені навчальні заклади компенсуючого типу (санаторні та спеціальні).

У загальній структурі загальноосвітніх навчальних закладів переважають школи державної форми власності, які складають 99\% загальної кількості подібних закладів. Лише 1\% припадає на загальноосвітні заклади приватної форми власності. Денні навчальні заклади складають 98, 1\% загальної кількості шкіл, а 1, 9\% припадає на вечірні школи [134].

Професійно-технічна освіта. Професійно-технічна освіта забезпечує здобуття громадянами професії відповідно до їх покликань, інтересів, здібностей, а також допрофесійну підготовку, перепідготовку, підвищення їх кваліфікації.

Система професійно-технічної освіти складається із професійно-технічних училищ, професійно-художніх училищ, професійних училищ соціальної реабілітації, училища-агрофірми, училищ-заводів, вищих професійних училищ, навчально-виробничих центрів, центрів підвищення і перепідготовки робітничих кадрів, навчально-курсових комбінатів, інших типів закладів, що надають робітничу професію. 
PEDAGOGY IN MODERN CONDITIONS

Професійно-технічна освіта має три ступені. Відповідно до ступенів професійно-технічної освіти встановлюється три атестаційні рівні професійнотехнічних навчальних закладів: навчально-курсові комбінати (I рівень); професійно-технічні училища (II рівень); вищі професійно-технічні училища та центри професійно-технічної освіти (III рівень).

Професійно-технічна освіта здійснюється у професійно-технічних навчальних закладах за денною, вечірньою (змінною), очно-заочною, дистанційною, екстернатною формами навчання, з відривом і без відриву від виробництва та за індивідуальними навчальними планами. В системі ПТНЗ здійснюється підготовка робітників за 342 професіями та 492 спеціальностями [134].

Вища освіта. Згідно з новим Законом України «Про вищу освіту», що набрав чинності 28 вересня 2017 року, вища освіта визначається сукупність систематизованих знань, умінь і практичних навичок, способів мислення, професійних, світоглядних i громадянських якостей, морально-етичних цінностей, інших компетентностей, здобутих у закладі вищої освіти (науковій установі) у відповідній галузі знань за певною кваліфікацією на рівнях вищої освіти, що за складністю $є$ вищими, ніж рівень повної загальної середньої освіти [133].

Структура вищої освіти України розбудована відповідно до систем освіти розвинених країн світу, що визначені ЮНЕСКО, ООН та іншими міжнародними організаціями. Вона забезпечує фундаментальну наукову, професійну та практичну підготовку, здобуття громадянами освітньо-кваліфікаційних рівнів відповідно до їх покликань, інтересів і здібностей, удосконалення наукової та професійної підготовки, перепідготовку та підвищення кваліфікації студентів. Сьогодні Вища школа України готує фахівців із 76 напрямів i 584 спеціальностей, що дозволяє задовольняти потреби всіх сфер суспільного життя країни. 
У вищих навчальних закладах України вища освіта громадянами України та іноземними громадянами здобувається за освітньо-кваліфікаційними рівнями молодшого спеціаліста, бакалавра, спеціаліста та магістра.

Освітньо-кваліфікаційний рівень молодшого спеціаліста здобувається у вищих навчальних закладах I-II рівнів акредитації: училищах, технікумах, коледжах; бакалавра, спеціаліста та магістра - у вищих навчальних закладах IIIIV рівнів акредитації: університетах, академіях та інститутах.

Аспірантура. Основною формою підготовки науково-педагогічних i наукових кадрів у СРСР (з 1925 р.), згодом — в Україні була аспірантура. Термін навчання в аспірантурі був: 3 роки (стаціонар); 4 роки (заочно). Після проходження аспірантури до захисту у спеціалізованій вченій раді подавалася дисертація на здобуття наукового ступеня кандидата наук. Після успішного захисту дисертації науковий ступінь кандидата наук присуджувала спеціалізована вчена рада, але після цього відбувалося затвердження у Вищій атестаційній комісії України (1992-2010рр.), з 2010 року - у Атестаційній колегії МОН України.

Аспірантура відкривається при вищих навчальних закладах третього або четвертого рівнів акредитації і прирівняних до них закладах післядипломної освіти, у наукових установах, які мають висококваліфіковані науковопедагогічні кадри наукових керівників (доктори наук і професори), сучасну науково-дослідну, експериментальну та матеріальну базу.

За час навчання аспіранти оволодівають методами наукового дослідження $\mathrm{i}$ складають іспити в обсязі кандидатського мінімуму та виконують заплановану наукову роботу. Зараховані в аспірантуру з відривом від виробництва одержують державну стипендію. Після закінчення аспірантури аспіранти можуть подати на захист дисертацію, підготовлену на основі успішно виконаної наукової роботи.

Докторантура. Формою підготовки науково-педагогічних та наукових кадрів вищої кваліфікації в Україні є докторантура. В Україні докторантура відкривається при вищих навчальних закладах третього або четвертого рівнів акредитації і прирівняних до них закладах післядипломної освіти, у наукових 


\section{PEDAGOGY IN MODERN CONDITIONS}

установах, які мають висококваліфіковані науково-педагогічні та наукові кадри, сучасну науково-дослідну, експериментальну та матеріальну базу.

Відкриття і закриття докторантури у вишах, у наукових установах (за винятком наукових установ Національної академії наук) здійснює Міносвіти, а в наукових установах Національної академії наук - iï Президія. Згідно із Постановою Кабінету Міністрів України від 23.03.2016 змінено порядок підготовки здобувачів вищої освіти ступеня доктора наук. Вступити до докторантури може особа, яка має ступінь кандидата наук, наукові здобутки та опубліковані праці з обраної наукової спеціальності і яка в змозі на високому науковому рівні проводити фундаментальні, пошукові і прикладні наукові дослідження.

Отже, система освіти в Україні має багаторівневу структуру, що дозволяє впровадити в життя концепцію безперервної освіти. Більшість установ освіти всіх рівнів має державне або комунальне підпорядкування, сектор приватної освіти залишається недостатньо розвинутим.

Загальною тенденцією на всіх рівнях освітньої системи є скорочення протягом останніх років мережі навчальних закладів, що є наслідком складної демографічної ситуації, кризових явищ в економіці, політиці, а також реформ, що проводяться Міністерством освіти України. 
PEDAGOGY IN MODERN CONDITIONS

\section{SECTION 4. INNOVATION IN EDUCATION}

\subsection{Formation of communicative competence in primary school children based on psycholinguistics}

The problem of communicative competence of the younger generation has always been in the focus of attention of psychologists, linguists and methodologists. Scientists have investigated the psychological and psycholinguistic aspects of speech utterance perception and generation, the issue of the communicative quality of the culture of speech, the theory of speech norms, features of the speech culture of an individual and society, as well as the linguistic features of the culture of an individual's speech.

One of the effective means in formation of the communicative competence of primary school children, in our opinion, is the use of psycholinguistic technologies neurolinguistic programming, through which are carried out the knowledge and assessment of the objective reality; creating of positive mood situations in the process of communication, which leads to effective interaction of the speaker with the respondents.

The question of the application of neurolinguistic programming techniques in various spheres of human life has been studied by foreign specialists (R. Dittles, E. Rossi, B. E. Erickson, etc.), scientists and practitioners (M. A. Pavlova, V. V. Semenov, A. N. Sytnikov, V. I. Elmanovych and others). The problem of using neurolinguistic programming in education is currently being studied by $\mathrm{K}$. Andreas, A. D. Barbitova, Y. B. Gippenreiter, J. Grinder, R. Dilts, S.V. Kovalev, J. O’Connor, J. Seymour, M. A. Pavlova, B. Lewis and others.

Their research shows that the purposeful use of NLP methods and techniques promotes better awareness of the material, development of memory, thinking, attention and imagination, which affects the final results of educational activities.

However, today in formation of schoolchildren's communicative competence there is an insufficient level of modern achievements implementation of psycholinguistic science in theory and especially practice of the learning process, the 
superficial nature of diagnostics of the neuropsychological determinants of pupils' mental strategies as a basis for communicative skills.

To ensure the mechanisms of schoolchildren's communicative competence formation, we propose to use previous empirical and theoretical experience, which is most fully reflected in the field of applied psychology, called neurolinguistic programming (NLP).

First of all, let's consider the history of this technology. NLP appeared a little over thirty years ago at the American University of Santa Cruz. The founders of NLP are John Grinder and Richard Bandler. Their research was based on the work of famous practical psychotherapists Fritz Perls (Gestalt therapy), Virginia Satyr (family therapy) and Milton Erickson (modern hypnotherapy). Based on the generalization of their work, Grinder and Bandler developed NLP as a model that describes human mental processes and offered people schemes for achieving the success in various fields (Bandler and Grinder, 1977).

These investigations allow making assumptions that the use of neurolinguistic programming techniques in formation of the communicative competence will stimulate children's speech and creative activity that will lead to the creative use of the content of syntactic material in their statements. Creativity is always the introduction of something new into the educational process, which leads to improvement, stimulates the development of self-organization (Mikhalskaya, 1996).

Today, neurolinguistic programming technologies have largely shown their effectiveness and penetrated almost all spheres of life, began to be introduced into the educational system, as they study the structure of thinking, development of speech, attention, memory, perception of the world. Because of the widest potential of NLP, it is necessary to adapt it to the process of learning, transfer to a system of technologies that can be used by teachers of educational institutions.

Each pupil has certain abilities for something. The teacher's task, when he uses the methods and techniques of neurolinguistic programming is to find the smallest shoots of talent, and develop them. After all, in the future, every child will benefit from a strong memory, accuracy, good taste, figurative speech. 
Neurolinguistic programming technologies are a specially organized sequence of actions that meets the following conditions:

- give the expected results;

- correspond to the technique "step by step";

- technology does not depend on the specific content and form of organization, so it has a universal application.

Neurolinguistic programming is often called the art and science of personality's improvement, because it allows controlling the state of psyche, teaches to combine values and beliefs with the desired results ("programming").

According to NLP, a person receives, encodes and stores information by using four main systems of representation:

- visual - in the form of images (dominated by vision);

- auditory - in the form of sounds and words (dominated by hearing);

- kinesthetic - motor sensations dominate;

- digital - generalized ideas and mental processes dominate (Bandler, Grinder, 1977).

This division corresponds to the types of memory described by P. P. Blonsky: motor, or memory-habit; figurative, or memory-imagination; logical, or memorynarration (Blonsky, 1969).

Knowledge of the system of ideas that prevails in a particular schoolchild, allows the teacher to organize the presentation of information more effectively and facilitates the process of a new message remembering, as well as it removes barriers on the way to gaining the new knowledge, which is often associated with "incompatible" method of work chosen by the teacher and the leading modality of the schoolchild, his attitude to the content of the statement and the attitude of the content of the statement to reality.

In the process of teaching, the teacher takes into account the desired sensory channels of schoolchildren's information perception and their dominant representative systems, which allows significant increase of the effectiveness in learning if he uses methods and models of neurolinguistic programming.

To test the effectiveness of communicative competence formation in primary schoolchildren based on psycholinguistics, 50 participants of the experiment were 
selected - pupils of the 3-rd grade. All respondents were respectively divided into 2 groups - experimental and control (25 in each). Pupils were taught 10 lessons to develop coherent speech in each class. In the control group, classes were held according to the traditional system. In the experimental class, the technologies of neurolinguistic programming were involved into the educational process: in the classroom, we placed children on predetermined places depending on the priority of their sensory channel of information perception; used verbal and non-verbal methods of communication in the process of adjusting and leading the group during training sessions; applied multimodal presentation of educational information, used NLP exercises, involved all their representative systems and their learning styles; used the model of neurolinguistic programming (TOTE model).

We offer a set of neurolinguistic exercises that were used in the experimental work on communicative competence formation in junior schoolchildren.

Exercise "Training attention by focusing on the object of speech".

The course of the exercise: students are asked to choose a subject on which their own opinion will be expressed; put it in front of their eyes so that it is in sight; stop the internal dialogue, relax; focus on the object of speech for 5-7 seconds; be distracted for 5 seconds and refocus on the object of speech; identify the characteristics of the subject with the help of words and expressions.

The essence of the exercise is as follows: the total time spent per day on concentration on the selected subject should take about 10 minutes. In this way, students learn to turn off the internal dialogue, focus their attention on the object of speech, which helps to develop their attention and focus on even the smallest details of the subject.

Exercise 2. "Emptiness".

The course of the exercise: children are asked to choose any subject; stop the internal dialogue and look at the selected subject. As soon as the child begins to be distracted, he should close his eyes and try to see this object with his inner vision; describe it using familiar words. 
PEDAGOGY IN MODERN CONDITIONS

The essence of the exercise is the next: the pupil could return to a state where thoughts will not interfere with concentrating on the subject.

Exercise 3 "Remember - forget".

The course of the exercise: choose any subject; look at it for 3-5 seconds while inhaling, photographing it by thoughts; close the eyes and hold the image of the object for 3-5 seconds, holding the breath; while exhaling, "erase" the image from memory (somebody can imagine burning, erasing with an eraser or rag). Try to reproduce with the help of speech the characteristic properties of the subject.

This exercise helps the better memorizing all the characteristics of the subject for further reproduction in their speech.

Exercise 4 "Memorization - Retention".

The course of the exercise: disable the internal dialogue; to look at an object for 3-10 seconds through the centre with a distracted gaze; close the eyes and during 3-5 minutes try to evoke the appropriate picture, comparing it with the original; open the eyes and compare the internal reflection with a real object. Describe the own results.

In the process of performing this exercise, schoolchildren develop the ability to focus on the details of the subject, to compare imaginary and existing reflection with each other.

Exercise 5. "Draw with thoughts."

The course of the exercise: to look at the object for a few minutes; turn away and look at the white sheet of paper; try to evoke the image of the object so that it mentally appears on paper.

During performing the exercise can be used pictures, photos, postcards, words, sentences. This exercise promotes the development of figurative speech of children.

Exercise 6. "Instant photo".

The course of the exercise: look at what surrounds you; close the eyes; imagine the already seen picture; try to feel it; reproduce the own feelings in the utterance.

Feelings contribute to better remembering of the picture details, which helps to develop memory, stimulates children's speech and thinking activity. For better stimulation of speech, they were asked to perform the exercise "Portrait". For this, 
during the day the child should look at the person, then close his eyes, imagine the person he saw with his inner vision and mentally describe him.

To form the communicative activity of the listeners, we used such exercises as "Living Images" or "Animated Heroes", when school children consciously imagined themselves in the image of a hero of the story and reproduced their feelings following the new image.

Performing of the suggested exercises helps to develop children's imagination, memory, thinking and speech. Such NLP exercises can be applied both to subjects and to linguistic units or spellings, which pupils must memorize and reproduce in their speech according to generally accepted rules.

Besides, during the training we taught children in the process of conversation with the interlocutor, depending on the communication situation, to use established in NLP speech patterns, which contributed to a positive result of communicative activities. Thus, children mastered the features of using active vocabulary in their speech in the process of communicative interaction with the recipient.

As a result of training, school children of the experimental group, in contrast to the control, built their speech more competently, they were able to navigate in terms of communication and reframing, i.e. rethinking and rearranging the mechanisms of perception, thinking, behavior of participants, used in their speech mostly those syntactic units that most effectively affect on the representatives of various representative sensory channels of information perception.

Based on the results of the study, it can be argued that improvement of the quality of schoolchildren's communicative competence formation is possible if a complex of diagnostic methods and models for determining the foreground sensory channel of information perception and the dominant representative system of listeners is introduced into the pedagogical process. It allows the most effective using of methods and NLP models in the process of speech communication development. The location of schoolchildren in the classroom should be done under the priority of their sensory channel. It will help to determine the modality of the mental process, to establish a report with them through adjustment, to assist them in reproducing or achieving a 
PEDAGOGY IN MODERN CONDITIONS

positive state and cognitive patterns associated with learning. For this, the teacher must have the skills to observe and analyze behavioral macro- and micro-signals of schoolchildren; use in the process of learning a set of methods and models of neurolinguistic programming based on feedback, which provide maximum use of all their representative systems and learning styles and improve their psychophysiological performance.

Methods of teaching Ukrainian language and formation of primary schoolchildren's communicative competence involves modelling of the pedagogical process with the optimal combination of traditional and innovative methods, techniques and teaching aids, including methods and techniques of neurolinguistic programming aimed at improvement of their communication culture. 


\subsection{The use of interactive teaching methods for students at the department of pathological physiology of Vinnytsya National Pyrogov Memorial Medical University}

The article presents interactive forms of students' extracurricular work organization in Vinnytsya National Pyrogov Memorial Medical University, held at the Department of Pathophysiology. In order to form creative and communicative qualities in medical students, improve professional competence, master the ability to work in a group and independently, the experience of using the following interactive learning technologies is offered for consideration: "Patphys League", "Brain-Ring", the Olympiad, Pathophysiology Club with reports and holding a conference of students and young scientists "The first step into science". Providing individualized conditions and forms of students' independent work organization improves their motivational qualities in self-educational professional process, which implements the objectives of educational programs of higher medical schools for training of highly qualified specialists.

Key words: interactive teaching methods, "Patphys League", "Brain-Ring", Olympiad, thematic club with reports.

Rapid technology development in the XXI century dictates the importance of constant searching for methods and approaches aiming to modernize classical medical education [139-141], which was based on the direct knowledge transfer from teacher to student. Given the globalization and quick availability of information, including medical, there is a need to structure it and focus on extracurricular student work. Effective implementation of independent work is focused on overcoming the formalism of knowledge obtainment, which practically depends on motivational aspects of students. An important and very necessary aspect is the teacher's ability to teach students to learn independently, to look for new data in literature, as medical sciences, pathophysiology in particular, are developing rapidly today. Therefore, it is important to explain to the student that knowledge acquired during the years of study at the university will be supplemented and changed. In the period of reforming medicine in Ukraine, with an emphasis on its decentralization [142], a medical student 
must have not just knowledge, but a number of qualities that will help them realize their professional potential. What are the key competences of a future practitioner nowadays? In addition to a humane attitude to the patient and high level of responsibility for their actions, the student must develop a critical attitude towards the data obtained, the ability to filter information, innovation, and creativity of thinking. There is no doubt that the communicative compliance of the doctor and the patient is the basis of the prescribed treatment effectiveness. In addition, taking into account rapid development of so-called artificial intelligence, which can become an alternative to sacred classical medicine, the doctor of the future must be socially oriented.

In recent years, at the Department of Pathological Physiology of Vinnytsya National Pyrogov Memorial Medical University methods of interactive learning are used, which are based on the conditions of constant, active interaction of all the participants in the learning process in order to optimize the extracurricular work of 3rd year students [143]. Organization of interactive learning involves various life situations modeling, cooperative problem solving based on the analysis of situation and circumstances, and role-playing games usage [144]. Thus, the department has introduced the following interactive forms of education: "Pathphys League", "BrainRing", Olympiad, meetings of the thematic club. Such alternative teaching methods contribute to the activation of educational and cognitive activities of students, encourage them to make mental and practical work in the process of mastering the material, when not only the teacher but also students are active. Characteristic didactic features of alternative learning methods are the following: professional interest, nonstandard approach to educational and cognitive activities, competitiveness, playful and emotional nature with an emphasis on reflection.

"Patphys League" is a kind of educational and entertaining activity on the basis of the Department of Pathophysiology of Vinnytsya National Pyrogov Memorial Medical University. Conducting a pathophysiological quiz is based on the presentation of competencies acquired by students in an informal setting. In addition to excellent knowledge of the discipline theoretical materials, students must be creative during tasks implementation. The idea of creating such an intellectual event belongs to prof. 
N.A. Rykalo. The desire to increase the interest of medical students to pathophysiology became a motivation to look for new ideas. This creative search resulted in the premiere test competition in 2015, after which it has now become a tradition and an expected event. Usually, the quiz is attended by teams of 3rd year students of medical and pediatric faculties of Vinnytsya National Pyrogov Memorial Medical University. Each team consists of 10 students with a high or medium grade in the discipline. It is the last criterion for selecting students to participate in the "League" that motivates them to systematic high-quality preparation for practical classes and lectures. The intellectual game begins with a welcoming speech by the head of the Department of Pathophysiology, MD, Professor Rykalo Nadiia Anatoliivna, then the presenter represents the teams, the teaching staff of the jury, the counting commission, and the competition begins. The jury consists of the teaching staff of the department with many years of experience in such events holding. The "Patphys League" consists of 5 competitions.

The first of which is "Video Greetings". The theme this year was the idea for students to present in a witty way the importance of "Pathophysiology in my life." In the videos, students introduce the name of the team to the jury and the audience, show a comedy scene on pathophysiological topics, focusing on how they see themselves in the 3rd year, studying at a medical university, mastering knowledge of pathophysiology.

The second competition - "Business Card" is a logical continuation of the first, where teams present themselves on stage in person. Students are invited to the hall to greet the audience. The duration of the performance is about 7 minutes. The order of performance is determined by drawing lots.

Representatives of the team take part in the blitz contest called "The Smartest". The team that gives the maximum number of correct answers to the presenter's questions in 1 minute wins. Each team is given the opportunity to answer 18 pathophysiological questions. The student has the right, when not knowing the correct answer, to say "Next", in order not to lose precious seconds. For each correct answer the team receives 0.5 points. 
To participate in the fourth competition - "Crocodile", 5 participants from each team are invited. Terms of the competition are as follows: by drawing lots, each team gets a pathophysiological concept, and then depicts it for other teams. Other commands' answers are accepted in writing. Teams receive 1 point for every correct answer. Thus, the team that guesses the task of all other teams gets 4 points. Separately, the jury evaluates the teams for how they portrayed the task for rivals. The maximum score is 5 points. The maximum time for the presentation of the concept is 3 minutes.

The fifth competition is "Homework". The main difference of this competition in our quiz is its thematic focus. This year we decided to add a bit of music to our league. Therefore, the "Homework" competition will consist of a certain pathology presentation. The pathologies were received by teams in advance by drawing lots. The performance time is about 7 minutes. The maximum score is 5 points.

As in any quiz, at the end the jury determine the winning places, which are awarded with motivational prizes. The most desirable one is the additional points received by all the participants of the educational and intellectual event in pathophysiology, which improve the rating of current student performance. When deciding on the winning team, the following criteria must be taken into account, such as: compliance of the performed tasks with the specified topic, creativity and individuality, creative work, charisma of the team members. One of the main criteria that determines the leader among the five teams-participants is the level of theoretical background and knowledge of pathophysiology; the ability to combine and present them in a witty way with a sense of humor is highly valued by the chairman and jury members. The ability of medical students to write a thematic text to the song, put a short humorous performance on the studied pathological processes (e.g., types of allergic reactions, hypoxia), allows, on the one hand, to get moral satisfaction from the process, and to deepen knowledge - on the other.

Many years of positive experience in conducting such extracurricular activities as a pathophysiological quiz gives students the opportunity not only to improve their interdisciplinary competencies, but also to present themselves as smart and talented future doctors. Competitiveness, as a basic criterion of such activities, intensifies the 


\section{PEDAGOGY IN MODERN CONDITIONS}

cognitive process, improves motivation for learning, imagination, thinking, cultivates independence, willpower, team spirit and brings great satisfaction to all participants of the quiz. It should be emphasized that modeling the situation of success as a reward for the effort is an effective motivational incentive for further learning. In addition, the student learns to present himself and his knowledge and skills, which will make him a sought-after specialist in the labor market in future. 


\subsection{Innovation in education: psychological bases of language learning}

\section{Globalization as reflection of knowledge about language}

Scientific picture of the world includes system of knowledge about the person, his place in worldwide area, space. It is synthesis of lore, based on fundamental principles, ideas worked out scientifically in current historical moment. If In XIX century the world picture was interpreted as philosophical and worldview formation, then for XX century (specially for the second part) it is scientifically philosophical system of representations about world's properties and patterns (of nature and social sphere). Human's potential of any modern nation has directed connection with educational organization, especially-high education, which is forming intellectual, creative and ruling elite of society. Well-known that globalization is, first of all, consequence of break out in the world of informational technologies and system, which are global by their nature. Global worldis utterly informatized world. In modern society under the pressure of globalization and informational bang, happens active transformation of scientific world picture, which found its own reflection in scientific researches of Ukrainian scientists.

So M.Yu. Yaremenko explores the informational picture of the world as a sociocultural reality [144]. V.V. Kolotilo in the article "The Modern Picture of the World and the Worldview of Person" describes the specifics of the formation of the worldview of man in the sight of modern technocratic trends [145]. Chernova L.P. in the work "The scientific picture of the world as a subject of philosophical discourse" analyzes the genesis and interaction of different sciences, proving that based on the scientific picture of the world an active comprehension of the truth, the laws of natural and social being takes place [146]. Sidorenko V.K. considers the formation of an information technology society in the light of modern secondary schools [147]. In the basis of thesis os Kuzmenko V.V. "The theoretical and methodological foundations of the formation in students of a scientific picture of the world in the history of the development of school education (XX century)" the idea of cognition of reality by a person is putted in [148]. Based on the study and analysis of scientific literature, 
archival documents, pedagogical practice, the author explores the genesis of the formation of a scientific picture of the world, defines methodological approaches and theoretical and methodological foundations of the formation of a scientific picture of the world as a product of students theoretical and practical activities. In his next work "The development of scientific pictures of the world as a result of the historical formation of science and education", methodological approaches to the formation of a scientific picture of the world as a result of theoretical and practical human activity are determined, structural components that influence the process under study are identified, and the influence of education on it is proved. The work of N. Ashitok emphasize the need of using educational potential in the formation of a scientific picture of the world on a humanistic basis $[149,150]$. The linguistic picture of the world is a system of concepts that is characteristic of each language individually, with the help of which native speakers classify, interpret the world. The study of the linguistic picture of the world is the path to a better knowledge of the specifics of any language, the evolution of the system of concepts of each nation, its identity and mentality. At all stages of historical development, the linguistic picture helps to take a deeper look at the features of the development of society. Ethnolinguistics, sociolinguistics, psycholinguistics are engaged in studying the linguistic picture of the world, as a separate people, and conducting comparative studies on the material of several languages. A huge contribution to the study of this problem on the lexical material of several national languages was made by linguistic professors I.A. Golubovskoy [151], U .L. Mosenkis [152].

Thanks to the language, we arm our consciousness, which allows us not only to limit ourselves to acts of communication, but also to develop a mechanism for participation in the socio-cultural environment. The psychologist Bergson believed that the main function of the intellect is rubrication. "To explain something means to see in a new and unforeseen elements of the old and familiar, organized in a new order" [153]. The essence of the language is not in the use of any method of communication, but in the use of fixed associations, it means that something tangible - a spoken word, picture, gesture, or whatever - could trigger an idea of something else. When this happens, the 
tangible can be called a "sign" or "symbol", and what the idea is about is "significant". Therefore V.A. Zvegintsev calls language a means of mentally dividing the world around us into discrete concepts, and also an instrument for classifying these concepts [154]. According to F. de Saussure, the word as a linguistic sign is "two-sided psychic essence", which rests on the inextricable connection between the concept and its acoustic image. Wherever a new word appears for a person - in oral conversation, from the pages of a book or newspaper - in all cases it will be stored in memory as a sound image. This image at any time can be imagined mentally (through the so-called "internal speech") or reproduced aloud. And invariably at the same moment an abstract concept pops up in memory that corresponds to a given acoustic image. The natural language of man carries out semiotic modeling and thereby serves as a universal semiotic matrix on which to build a virtually unlimited number of a wide variety of familiar or informational systems.

The linguistic-psycho-mental activity of modern human is aimed, on the one hand, to transmit information, and on the other, to its perception. Therefore, in communicative situations, such components as communication attitudes, knowledge of the social system, cultural norms and values are manifested. The current social reality forms the behavior of the personality culture, determines the range of language resources, which are a projection on the social organization of society, and with the help of which the realities of the development of society are interpreted. Therefore, the problem of mobilizing diverse knowledge in the field of personal activity, and, accordingly, language competence, form a new layer of scientific achievements.

In the process of communicative interaction, the communicants are ready to respond quickly to changing circumstances, adjust behavior, and, accordingly, units of linguistic activity that characterize communicative skill are distinguished. «Verbal communication is based on the definition of lexical units that correspond to the realities of the world or focus on them ... A successful communicator conducts its communication in advance as planned. This is an option for an actor who already knows when the audience will laugh and when he will cry, because he has experience 
in the plurality of plays performed. This is knowledge of the metacommunicative plan of the level of professionalism».

The communicator activates all internal and external receptors that determine the depth of the psyche, affect the formation of different types of behavior, and regulate activity. So linguistic parameters with the help of markers are transcoded into social ones. Therefore, it can be argued that the specifics of the formation of the scientific picture of the world in the modern language space for teaching Ukrainian students depends on situational and psychological components, connotations in a wide sense, and also interpretation of units of the language code.

\section{Specialization of mental functions in the process of language acquisition}

The studying of ancient languages, of which Latin is of no small importance, at the current stage of development of higher education covers not only actual problems of teaching foreign languages, but also becomes a component of the professional training of future professionals.

According to the American methodologist, professor of the University of Chicago Peter Hagboldt, teaching foreign languages can pursue practical and educational goals, the choice of which depends on objective conditions and on the duration of the course. The method, in his opinion, is a set of techniques aimed at achieving a certain goal within a certain period of time in the presence of certain teaching aids, taking into account the age and general development of students, as well as schools and society. The method is never invariably frozen; it must be adjusted when the teaching conditions change. The main goal of a linguistic teacher in the classroom is to simplify the process of language learning as much as possible. After all, it is the teacher who acts as a predictor, since he must provide for possible error options in solving predetermined tasks, as well as find ways to overcome them. "It is much easier to succeed when each individual task is considered as part of the general task, and not as an independent one ... When a student does not know the ultimate goal of training, ... he resorts to a relatively easy way to satisfy his requirements and verbally memorizes 
material either from a textbook or ... as explained by the teacher "[155]. The realization that the general task is much wider, involuntarily and subconsciously makes students concentrate their efforts on the subject under study.

The specialization of mental functions in the process of development history is accompanied by a complication of the "anatomy" of the psychophysical activity of a living creature: activity is divided into actions, and actions into operations. Therefore, each level of the mental has its own qualitatively different content, determined not by simply summing up the information of the lower floors, but by the type of tasks to be performed to ensure the practical life of the body [156].

Acquiring receptive language skills is incomparably easier than acquiring reproductive language skills. We can learn to read yet not knowing how to express our thoughts $[155,182]$. Thus, it can be argued that there is an interdependence of various types of speech activity - listening, reading aloud, reading to oneself, speaking, writing. Consequently, there is a merger of certain types of speech activity into a single whole.

To understand a foreign language ... knowledge of its phonetics and vocabulary is completely insufficient. Without knowledge of grammar, we can only approximately understand the most simple phrases. For the deaf-mute, the sound language in which the people of his homeland communicate speaks in the same capacity as ... a language for a Frenchman or an Englishman. And if the translation of lexical concepts from the spoken language into the language of the deaf-mute should cause noticeable difficulties, then these difficulties grow immeasurably when we encounter the problem of gesture expression of grammatical categories (gender, case, time, etc.) [157].

Hearing does not include operations that would not go into speaking; but speaking includes all the operations involved in listening, plus the logical operations of viewing the future and choosing. The logistics of speaking is somewhat reminiscent of an amateur game of chess, where it is allowed to "take moves back" and where you can often not see the situation on the chessboard (not even notice that the king has been declared a check!) [158].

All languages have methods of limiting regression, methods of preserving depth, as well as methods that make it possible to circumvent the limitation of the amount of 
memory in order to preserve expressive power [159]. Psychologists have measured what is called the amount of immediate memory. We are able to remember at a glance and correctly reproduce approximately seven decimal digits taken at random, about seven unrelated words, about seven names. This has long been studied at Harvard University by J. Miller [160]. The largest number of units that can be perceived, remembered and recreated by an ordinary person after the first presentation is approximately $7+(-) 2$. Thus, the Miller magic number indicates the number of units of information held in memory. And although forgetting is undesirable in learning, researchers say: the largest percentage of forgetting falls on the first 48 hours after perceiving or memorizing the material. Therefore, a single individual must develop its own system of memorization and reproduction of information.

According to the law of Yerks-Dodson (“optimum motivation”), to achieve success requires an optimal (or, more simply put, moderate, average) level of motivation. As a result of experiments conducted on animals, and later on people, it turned out that weak motivation is not enough for success, but excessive motivation is harmful because it generates unnecessary excitement and fussiness (when people worked "through the sleeves" for a purely symbolic gain, and the results were not high; and as the rewards increase, so does enthusiasm; the results accordingly improve).

Optimum motivation can be achieved in the process of forming the goal. This contributes to attention. Thanks to him, consciousness focuses on a specific object. In the dynamics of attention, the ability to set a goal is of utmost importance. The setting and constant refinement of the goals of activity arouses, maintains and switches attention [161].

Attention indicates the purpose of possible practical actions. To make them possible from the possible, the goal must be presented as a task, i.e. must be recognized, appreciated and appropriately expressed. The formulation of the problem and its phased solution takes on the cognitive function of linguistic consciousness [158].

This way, in the process of learning the ancient language and the learning process, it is necessary to consider the following: 
there is a complex mechanism of perception and understanding of language units, which can cause possible cases of bias in the adequacy of the understanding of the text;

in practice language, stereotypes of thinking and stereotypes of linguistic turnarounds may arise; therefore, an exact setting on a logical, rational perception of a word is necessary;

the possibility of using combined types of building classes entails focusing on specific issues (e.g. phonetic norms, morphological structure of the language, structural and semantic features of phrases, semantic and functional characteristics of the word, etc.).

Thanks to the language, we arm our consciousness, which allows us not only to limit ourselves to acts of communication, but also to develop a mechanism for participation in the socio-cultural environment.

\section{Innovative technologies in the study and teaching of foreign languages}

The reality of today is the expansion of Ukraine's international relations and its integration into the world community. In these circumstances, more and more attention is paid to the study of foreign languages, and this applies to all spheres of life [162, 163], where foreign languages are key to the development of international relations, scientific conferences, cultural exchanges between representatives of different countries and exchange of information.

The need of modern society for agricultural specialists who are fluent in foreign languages in everyday life and in their professional activities, necessitates the search for new constructive ideas to solve the problem of optimization and intensification of foreign language learning, acquisition of new knowledge and improvement of the level of language and speech.

Nowadays, the demand for specialists with advanced level of foreign language skills and specific technical terminology has increased. Therefore, in higher education institutions should be created favorable conditions for the use of all the technical capabilities of today in the search and obtaining the necessary information, the 
PEDAGOGY IN MODERN CONDITIONS

formation of cognitive qualities of students. It is no secret that for most high school students, high school students and students, vast spaces of information selection are related to access to and use of the Internet resource [164].

World experience shows that "... the solution to the problems of education begins with the professional skill of teachers. After all, without qualitative growth of pedagogical professionalism, we are destined to remain in the past" [165]. Therefore, training and control systems, information retrieval systems, modeling programs, cognitive and versatile tools, as well as communication tools are needed [165].

Computer programs have many advantages over traditional foreign language teaching methods. They allow you to train different types of speech activities more effectively, develop linguistic abilities, create communicative situations, allow you to maintain constant contact with the native speaker and bring an element of interest in achieving the ultimate goal.

The outstanding psychologist of the beginning of the last century LS Vygotsky formulated the main task of pedagogy of the future, in which life emerges as a system of creativity, constant tension and overcoming, constant combination and creation of new forms of behavior. "This way, every thought, every movement and every experience is... the desire to create a new reality, a breakthrough for the new..." [166].

The main task of teachers in the process of applying innovative technologies is to implement training computer programs, improve their content and optimize the organization of the Web space.

The most common way of incorporating computer technology into the education system is through the use of automated training courses and e-learning. The most popular programs in this field are Learn to Speak English, Tell me more, Business English etc. In addition to special programs, electronic dictionaries such as Lingvo, Multitran and others are in high demand.

Audio and video recordings help students to understand their original text by ear. You can also use an interactive board (Smart board), which allows you to combine old proven learning methods with a number of interactive and multimedia capabilities [164]. 
One of the most exciting modern education opportunities offered by cutting-edge technology is the creation of micro worlds. Micro worlds are special, highly specialized programs that allow you to create a special environment for your computer to investigate specific issues. This is a computer simulation that will allow students to naturally acquire the necessary knowledge.

Today, a teacher does not need to be a programmer to create an electronic test. Programs such as Master-Test, Super Test, PS-tester help to solve this problem.

No technology can be considered perfect. We need to be prepared for the changes that bring the newest living spark to the teaching and learning routine. The problem is not to completely deny or unconditionally adopt the information technology training needed to reform education. It is about their role in the modern scientific and pedagogical space. Not only does information technology extend our capabilities, it also helps to narrow and standardize our thinking, as the whole multifaceted world shrinks to an edited virtual world that demonstrates the Internet.

\section{Grammar is the sister of the future specialty}

For a long time, grammar was considered to be the only reliable basis for comparison. "Grammar is the area where generalizing facts from different languages is most feasible, finding some" common denominators "for them [167].

Comparison as a method of language learning has a number of advantages, allowing deeper study of the languages being studied and discovering new linguistic facts and phenomena that remain out of sight in separate consideration [168].

The main focus of the study of Latin, we traditionally focus on the comparison of phonetic and grammatical phenomena of the two languages - ancient and native. Therefore, on several occasions, teachers have to remind students that when learning ancient languages, not only dictionary data but also textual material can be used as a study material. It is also advisable to use materials of translation of the same texts into different languages [168]. An example would be a rational demonstration of Russian and Ukrainian variants of the medieval student anthem "Gaudeamus igitur ..." translated by S.I. Sobolevsky, NV Bugaeva, L.V. Ginsburg, E.M. Borovsky, N. Bilyka, 
A.A. Sodomory, V.D. Litvinov, etc. That is why we repeatedly remind in teaching classrooms that translation made by one author is not the only possible one and the choice of the variant depends on the individual taste of the translator.

The main goal of the teacher in the teaching classroom is to simplify the language learning process as much as possible. It is he who plays the role of a forecaster, as he should provide for possible variants of errors in solving pre-set tasks, find ways to overcome them. "He anticipates the difficulties and tries to prevent them, seeks to preserve the number of possible errors, and assists the student before the latter has spent time correcting the mistakes he could make and explaining them" [155].

Lasting success in learning a language depends first and foremost on your goal. "Success is impossible without a firm intention to achieve it. A certain purpose is needed for intentions and desires to become effective. Therefore, in any course of study, the goal must be clearly defined first. It is much easier to succeed when each individual assignment is considered as part of a common assignment rather than as an independent assignment... When a student does not know the ultimate purpose of learning, ... he resorts to a relatively easy way to satisfy his requirements and literally learns the material either in the textbook or in the teacher's explanation" [155]. The realization that the overall task is much broader, involuntarily and subconsciously forces students to concentrate their efforts on the subject being studied. Systematic scheduling of lessons depends largely on the amount of homework completed and their quality. Thus, pointless teaching and aimless learning disappear, and "every lesson becomes a skilful, well-considered step toward a specific goal" [155].

Karl Priam in the book "Brain Languages" gives the idea that there are certain areas in the brain that are responsible for the construction of phased plans of activity. The plan execution program is coded in such a way that its individual stages do not overlap, do not interfere with each other. Once fixed in verbal symbols, the plan of future actions can be stored in memory until we need to execute it [157]. An amazing feature of language is that it not only accumulates the entire experience of previous generations, but also transmits it in a concise and concentrated form to every new member of human society [157]. 
The word is not only a tool of thought transmission, but also a key to the message's mood [169]. Such multidirectionality forces us to study the word not only as an element of the language system (as part of the normative arsenal of language) but also as a component of the language process [169].

\section{Psychological bases of language learning}

The modern world is full of contrasts, contradictions and contradictions, which largely affects all spheres of human being. Civilization always faces the choice of social or natural orientation. We can go about the crowd, recognizing as the highest values that she recognizes, and we can dare to be ourselves and live as we see fit, guided by the deepest and most authentic level of one's self. But we must remember that this choice helps to shape the paradigms of communication of a new society.

German scientist Ratke regarded didactics as an art of teaching, a kind of practical skill that underwent changes in different historical periods. However, it must be remembered that the main element of learning is always the problem statement. It helps to think logically, makes the material more evident, promotes the formation of interest in scientific knowledge, teaches to find the answers to the questions, "grasping" truths, which are easier to recover on their own in case of forgetting information.

In order to prevent erasure of information from memory, it is necessary to use in the educational process:

- firstly, the different types of business training game (when the stages are gradually played out in a particular situation, and, accordingly, a discussion is designed);

- secondly, test tasks taking into account the psychological characteristics of the subjects tested in order to determine the level of memorization of training material, as well as designing information schemes for the professional training of specialists.

Successful reformation of the educational sphere in Ukraine, aimed at democratization of education and development of civil society, is impossible without careful analysis of the best achievements of foreign colleagues in order to find promising opportunities to use the world experience in Ukraine. However, issues 
PEDAGOGY IN MODERN CONDITIONS

related to test evaluation, its use in higher education, and questions about moral and technical aspects of testing remain problematic.

The questions of testing and test control, studied by V.V.Ilyin [170], are presented as a set of tasks of diagnostics of the level of educational and vocational training of graduates of higher educational institutions. The author of tests of professional competence examines the whole complex of final certification to solve typical problems:

-in a specific subject area;

-at a certain object of activity;

-in accordance with the direction of vocational training;

-with a help of specialty;

at the certified educational-qualification level.

The materials for the creation of the tests were the training manuals "Workshop on Family and House Culture and Home Economics" in Latin, compiled by the author of the dpnnnaya publication [171], as well as individual author's development of practical classes in the disciplines, which were tested on many faculties of NULES Ukraine.

The use of the typical tasks presented by the test control should demonstrate the determination of the level of training of specialists in the field of knowledge, as well as the level of professional suitability (according to the requirements of educational and qualification characteristics of training of graduates of higher education institutions).

The best structure for test job conditions is to play professional situations. Depending on the task of control, the description of the situation may be short, but sufficiently complete, which allows the controlled person to obtain the necessary information. One of the advantages of using professional situations when formulating the content of test assignments is that they help to evaluate the application of knowledge in practice.

We hope that our comments will be useful, as innovative forms of training and test control in the learning process (on the material of the discipline "Latina") will help 
PEDAGOGY IN MODERN CONDITIONS

to form intellectually and spiritually mature attitude to the future profession, will contribute to the formation of culture and practical mastery of effective communication skills.

\section{Choosing and adhering to language learning techniques}

The problem of the ratio of learning and development has been and remains the core problem of pedagogy. At different historical stages its decision changed, which was caused by the change of methodological settings, the emergence of new interpretations of the essence of personality development and the process of learning, rethinking the role of the latter in this development. This was reflected in the writings of scholars of the nineteenth and twentieth centuries. KD Ushinsky, PF Kapterev, PP Blonsky, LS Vygotsky, ND Galskova, MP Suknov, TO Petrova, OA Sokolova, O. O.Andreeva.

The choice and adherence to teaching methods in the educational process depends on the goals and objectives, the degree of complexity, novelty and content of the educational material, etc. This is what determines the relevance of the chosen topic of the research - to find new effective teaching methods for work in a student audience. These issues require further and deeper research on foreign language teaching at higher education institutions, so the theoretical and practical relevance of the presented work is undeniable.

Updating the content of education is a decisive component of education reform in Ukraine and involves bringing it into line with the contemporary needs of the individual and society. Currently, the widespread ideas of "lifelong learning" and "education for all" are stimulating the emergence of new methods of knowledge transfer, as well as leading to the emergence of new learning technologies, among which distance education is at the forefront. Such technologies help to make visual information more saturated, dynamic, and to build the learning process itself, taking into account the active interaction of the student with the learning system.

It is estimated that $81 \%$ of all US higher education institutions offer at least one distance education course, $67 \%$ of educational institutions consider distance education as a strategically important area of their development. At the First International 
PEDAGOGY IN MODERN CONDITIONS

eLearning Conference in Moscow, eLearnExpo Director Sally-Ann Moore noted that the total market revenue from this type of training was $\$ 5$ billion, of which $\$ 3.5$ billion is in Europe.

The use of multimedia technologies in the study of foreign languages is also an urgent problem of the teaching staff of NULES of Ukraine. Because the use of audio and video makes more impression on the listener, makes such courses full, interesting, rich.

Experience has shown that the need for independent distance education is much more important, more mobile, and much more responsible than traditional teaching methods, as there are demanding specialists.

The state standard for the discipline "Foreign language" has three components: 1) general characteristics; 2) basic content; 3) requirements for the minimum level of preparedness of the students. Sample test tasks are added to the national standard to determine the level of foreign language skills. The principles of concluding foreign language curricula should also be taken into account: a communicative approach; integration; progression; differentiation; continuity; situationalism.

This uniqueness of didactic properties of computer telecommunication networks in the process of learning foreign languages is first of all that productive training of different types of foreign language activity can be carried out remotely due to the possibility of individual two-way telecommunication of the student with the teacher and simultaneously with the partner; access to numerous sources of language training information stored in the memory of network computers and disseminated through the in-house network.

We have developed electronic tests in Latina and English, as well as electronic tests in the Ukrainian language for foreigners to check the basic level of knowledge; created an electronic textbook in Latina for non-speaking faculties of universities of III-IV accreditation levels; an electronic handbook of Latin for students of the faculties of veterinary-medical profile, as well as an electronic Latina-Ukrainian and UkrainianLatina dictionary of veterinary-medical terms. 


\section{PEDAGOGY IN MODERN CONDITIONS}

The whole complex of teaching and methodological work of teachers is gradually being introduced into the educational process of NULES of Ukraine. In this way, new forms and skills of native speakers in real life situations are formed through distance

learning. This opens the door to a further career, giving you the opportunity to live more fun, learn and work harder. 


\section{4 Використання сучасних педагогічних технологій як запорука якісної підготовки майбутніх вчителів початкових класів}

У статті обгрунтовано значущість сучасних педагогічних технологій у процесі підготовки майбутнього вчителя початкових класів.

Ключові слова: технології, сучасні педагогічні технології, майбутній вчитель, підготовка майбутнього вчителя початкових класів.

The article substantiates the importance of the modern pedagogical technologies in training a future elementary teacher.

Key words: technologies, modern pedagogical technologies, future teacher, training a future elementary teacher.

Актуальність проблеми. Постійний розвиток суспільства, зміни в ньому, а також високи вимоги до якісної підготовки майбутніх фахівців зумовлюють потребу модернізації педагогічного процесу у закладах вищої освіти. Крім загальних знань зі спеціальності, майбутні спеціалісти мають оволодіти певним набором компетентностей, щоб після завершення навчання стати конкурентоспроможним фахівцем не лише в межах своєї держави, а й у світовому просторі.

Особливої значущості використання сучасних педагогічних технологій набуває у зв'язку з необхідністю підготувати учителя - професіонала Нової української школи, який прагнє не тільки до озброєння кожного учня міцними знаннями, уміннями та навичками, а й дбає про розвиток його критичного мислення школяра, вчить аналізувати ситуацію, планувати свої дії на кілька кроків вперед, адекватно оцінювати результати своєї діяльності, самостійно набувати і переробляти інформацію, вміння конструктивно взаємодіяти 3 іншими.

Сучасні тенденції розвитку початкової освіти потребують удосконалення та розвитку професійних умінь, гармонізації емоційних і логічних компонентів діяльності майбутніх учителів початкових класів та реалізації їх творчого потенціалу. Професія вчителя початкових класів близька до мистецтва. Вона містить у собі широкі можливості для творчої реалізації особистості педагога. 
PEDAGOGY IN MODERN CONDITIONS

Тому професійна підготовка потребує від майбутніх вчителів початкових класів не лише потужної системи знань у галузі психолого-педагогічних, фундаментальних, професійно орієнтованих дисциплін і методичних умінь, але й вияву особистісних якостей. Учитель з високим рівнем індивідуально-творчої продуктивності повинен вміти розв'язувати педагогічні ситуації, володіти унікальними методами і прийомами, підходами до кожної дитини. Такий вчитель досягне високих результатів у сфері професійної діяльності у галузі початкової освіти [175]. Тож проблема використання сучасних педагогічних технологій у процесі підготовки майбутнього вчителя початкових класів, на сьогодні, $є$ актуальною та науковозначущою.

Аналіз сучасної науково-методичної літератури свідчить, що науковці (В. Беспалько, М. Кларін, А. Нісімчук, О. Падалка, П. Підкасистий, О. Пометун, I. Підласий, О. Пєхота, І. Прокопенко, А. Сембрат, С. Сисоєва та ін.) приділяють значну увагу питанню професійної підготовки майбутніх учителів, розкриттю змісту сучасних педагогічних технологій та їх використанню в процесі підготовки фахівців-професіоналів.

Мета статті - полягає у розкритті важливості використання сучасних педагогічних технологій у процесі підготовки майбутнього вчителя початкових класів.

Виклад основного матеріалу дослідження. У науковій психологопедагогічній літературі подані різноманітні тлумачення поняття «педагогічна технологія» (їх налічують близько 300). «Педагогічна технологія - це системний метод створення, застосування й визначення всього процесу навчання $\mathrm{i}$ засвоєння знань, з урахуванням технічних і людських ресурсів та їх взаємодія, яка ставить своїм завданням оптимізацію освіти» [171].

На нашу думку, найбільш повне визначення сутності педагогічної технології запропонувала С. Сисоєва, яка розглядає іï як «створену адекватно до потреб і можливостей особистості і суспільства теоретично обгрунтовану навчально-виховну систему соціалізації, особистісного і професійного розвитку і саморозвитку, яка внаслідок упорядкованих професійних дій педагога при 
PEDAGOGY IN MODERN CONDITIONS

оптимальності ресурсів і зусиль всіх учасників освітнього процесу, гарантовано забезпечує ефективну реалізацію свідомо визначеної освітньої мети та можливість відтворення процесу на рівні, який відповідає рівню педагогічної майстерності педагога» [176].

Останнім часом у практиці навчально-виховної діяльності сучасного закладу вищої освіти все ширше поширюються такі сучасні педагогічні технології, як: ігрові технології навчання, інтерактивні технології навчання, інформаційні технології навчання, кредитно-модульна технологія навчання, проектна технологія навчання, технологія «Створення ситуації успіху» тощо. Одним зі шляхів удосконалення процесу навчання у сучасному закладі вищої освіти є комплексне використання освітніх технологій у підготовці майбутніх вчителів початкових класів.

Основними завданнями сучасних педагогічних технологій є [172]:

- виховувати духовно багату, інтелектуально розвинену, фізично досконалу особистість, здатну мислити й навчатися самостійно;

- формувати гуманістично-орієнтовану особистість (людина - понад усе; цінити людину за їі розум, людські та ділові якості);

- виховувати свідомих громадян незалежної держави;

- плекати творчу особистість для праці в умовах ринкових відносин;

- формувати потребу свідомого здобуття освіти та набуття навичок і вмінь, що є підгрунтям для опанування професії та подальшої професійної реалізації;

- сприяти виробленню вміння адекватно реагувати на зміни у професійній сфері та здатності (у майбутньому) змінити фах (за потреби).

Використання сучасних педагогічних технологій в умовах педагогічного закладу вищої освіти дає можливість здійснювати професійну підготовку майбутніх учителів початкової школи. Сучасні педагогічні технології підвищують ефективність процесу навчання за рахунок:

- проектування цілей та процесу навчання, програмування діяльності викладача і студента, забезпечення максимальної організованості і, як наслідок, - досягнення необхідного результату; 


\section{PEDAGOGY IN MODERN CONDITIONS}

- перенесення акценту в навчанні з викладання на спрямоване засвоєння знань, тобто визначення структури і змісту навчально-пізнавальної діяльності майбутніх фахівців;

- структуризації змісту навчання, яка зумовлює можливість оновлення відповідно до замовлення суспільства та вимог практики;

- відтворення процесу навчання і його результатів на основі блокової побудови навчальних курсів [173].

Академік О. Савченко вважає, що «основним призначенням педагогічних технологій повинен стати рух від людини освіченої - до людини культури». Це означає, що сьогодні необхідно здійснити культуро-творчий підхід до освіти [174].

Використання сучасних педагогічних технологій у процесі підготовки майбутніх вчителів початкових класів сприяє збагаченню їх професійнопедагогічної, зокрема професійно-методичної підготовки, наповнюючи її новим змістом, формами, методами і прийомами навчання, створюючи нові засоби навчання та вдосконалюючи діючі [172]. Технологічна грамотність майбутнього вчителя початкових класів дозволить йому усвідомити своє істинне покликання, більш реально оцінити потенційні можливості, подивитися на педагогічний процес із позицій кінцевого результату.

Висновки. Отже, використання сучасних педагогічних технологій дає можливість майбутнім учителям змінюватися і розвиватися, реалізувати свої можливості, вдосконалюватися і самоутверджуватися, дозволяє кардинально змінити навчальну й соціальну мотивацію студентів, розвинути їхню пізнавальну активність, самостійність та здатність до творчості, що, у свою чергу, $\epsilon$ важливою умовою формування їхньої професіоналізму. 


\section{5 Анализ компонентов специальных профессиональных компетенций студентов медицинского ВУЗа}

Особую актуальность в современных условиях представляют научнопрактические исследования по разработке и обоснованию профессиональных компетенций студентов медицинского ВУЗа, которые позволят повысить эффективность подготовки специалистов на базе использования средств информационно-коммуникационных технологий.

Среди всего комплекса компетенций, формируемых у студентов в условиях образовательного процесса, необходимо особо выделить специальные профессиональные компетенции в связи с их конкретной целенаправленностью на процесс подготовки студентов медицинского ВУЗа в условиях информатизации.

Необходимость формирования специальных профессиональных компетенций студентов медицинского ВУЗа обусловлена повсеместным внедрением в учебный процесс систем управления обучением. Только сформировав соответствующие профессиональные компетенции у студентов медицинского ВУЗа можно внедрить в учебный процесс и полноценно работать в системе управления обучением, как преподавателям, так и студентам.

Специальные профессиональные компетенции студентов медицинского ВУЗа могут быть сформированы в процессе преподавания дисциплины «Медицинская информатика», научно-исследовательской работы студента, подготовки на персональном компьютере самостоятельных работ, работы с ресурсами Internet. Проблемой формирования специальных профессиональных компетенций занимались Нежинская Т.А., Глазырина Е.Ю [176]. Работ в области формирования специальных профессиональных компетенций студентов медицинского ВУЗа еще нет.

К основным компонентам специальных профессиональных компетенций студентов медицинского ВУЗа мы относим: опыт; качества личности; самостоятельность, рефлексия личности. 
PEDAGOGY IN MODERN CONDITIONS

Раскроем содержание каждого из компонентов специальных профессиональных компетенций студентов медицинского ВУЗа:

1) опыт (знаний/умений, владений, алгоритмов действий/общения):

- опыт знаний - понятия и терминология современных информационнокоммуникационных технологий; особенности конфигурации персонального компьютера; особенности и принципы построения локальных вычислительных сетей; организация глобальной сети Internet; теоретические основы обработки информации; интерфейсы и алгоритмы работы с системами управления обучением (MOODLE, CATS, eLearning Server и др.) [177];

- опыт умений, владений, разработка алгоритмов действий - работа с прикладными программными средствами компьютера; ввод, обработка и хранение информации; сравнение функциональных возможностей однотипного прикладного программного обеспечения для решения профессиональных задач; анализ различных приемов работы с профессиональной информацией; разработка и грамотное применение мультимедийного материала; практический опыт работы с информацией в стандартных приложениях Windows; проведение научно-исследовательской работы по актуальным проблемам информатизации профессиональной деятельности [178];

- опыт общения - открытость к диалогу на профессиональные темы по основным вопросам информатизации медицинской деятельности; роли сетевых коммуникаций в медицине; электронным способам, средствам и методам работы с информацией; значению информационно-коммуникационных технологий в формировании новой инфраструктуры системы образования; специфике применения специального прикладного программного обеспечения для работы специалистов в области медицины; способность и готовность осуществлять общение в конструктивном и профессиональном русле, извлекать профессионально и лично полезную информацию из общения с однокурсниками и преподавателями; 
2) качества личности (мотивация, ценности, установки; способности, творчество; коммуникабельность, мобильность в мыслях и делах):

- мотивация, ценности, установки реализующиеся через мотивированное отношение к процессу обучения на базе использования средств современных информационно-коммуникационных технологий; проявление самостоятельной инициативы в обращениях за консультациями в период выполнения практических работ по дисциплине «Медицинская информатика» для решения профессиональных вопросов или трудностей в области обработки информации;

- способности, творчество - сознательное приложение усилий и труда по развитию специальных способностей (в области компьютерной и других видов профессиональной деятельности); потребность и желание в нестандартном и оригинальном выполнении поручений, заданий, выражений личностной и профессиональной индивидуальности средствами современных информационно-коммуникационных технологий;

- коммуникабельность, мобильность - соблюдение этики в межличностных отношениях, корректное поведение в коллективе и информационном сообществе; способность к сотрудничеству и заинтересованное отношение к конструктивному общению на основе профессиональных интересов и средств современных информационно-коммуникационных технологий; своевременная и грамотная реакция собственных мыслей, действий и поступков на изменяющиеся ситуации и условия труда в условиях информатизации;

3) самостоятельность личности, рефлексия (самоопределение, самоанализ, самоконтроль, самооценка, самообразование, самореализация):

- самостоятельность личности (подлинность, одноличность) - центральный архетип личности, вокруг которого концентрируются все психические свойства человека; приближение в собственном мышлении, труде и поведении к идеальному образу профессионала, специалиста, стиля работы, общения, поведения в условиях информатизации; 


\section{PEDAGOGY IN MODERN CONDITIONS}

- рефлексия - способность и потребность в самоанализе и рефлексии процесса и результатов своей работы, общения в коллективе и личностного роста; целенаправленная работа по выработке навыков самоконтроля и самооценки в различных профессиональных ситуациях; потребность к самообразованию в сфере информационно-коммуникационных технологий [179].

Приведенные компоненты специальных профессиональных компетенций студентов медицинского ВУЗа обеспечивают основу восприятия студента новых условий информатизации в которых работают все больше ВУЗов. Формирование специальных профессиональных компетенций позволит студентам с легкостью работать с новыми информационно-коммуникационными технологиями на базе которых формируется информационное пространство ВУЗа [180]. К основным информационно-коммуникационным технологиям можно отнести набирающие популярность системы управления обучением (MOODLE, CATS, eLearning Server и др.).

Типовая система управления обучением представляет собой систему в которой все одновременно являются потенциальными преподавателями и студентами. Данный принцип предполагает новую ступень взаимоотношений, когда преподаватель должен не только стать для студентов источником знаний, но и направить их на самостоятельный путь поиска информации на базе единой информационной площадки.

Отдельно выделим специальные профессиональные компетенции студентов медицинского ВУЗа в области работы с системой управления обучением: умение работать с ресурсами глобальной сети Интернет; понимание и умение работы с элементами системы управления обучением (анкета, база данных, внешний инструмент, глоссарий, задача, лекция, обратная связь, опрос, пакет SCORM, семинар, тест, форум, чат); умение применять на практике знания в области информационных технологий. 


\section{PEDAGOGY IN MODERN CONDITIONS}

Таким образом, сформировав специальные профессиональные компетенции у студентов позволит им быть полноценными участниками информационного пространства медицинского ВУЗа. К основным компонентам специальных профессиональных компетенций студентов медицинского ВУЗа мы относим: опыт; качества личности; самостоятельность, рефлексия личности. Дальнейшим направлением данного исследования является расширение компонентной структуры, выявление критериев и показателей специальных профессиональных компетенций студентов медицинского ВУЗа. 


\section{6 Напрямки освітніх інновацій в умовах інтеграції гуманітарного та природничого знання}

Реалії XXI століття яскраво засвідчують нагальність реалізації провідної тенденції розвитку сучасності: формування синкретичної єдності різних напрямків наукового пошуку та різноманітних способів пізнання світу у всіх сферах життя.

Відходить в минуле чітка диференціація наук, антитеза «науки та мистецтва» втрачає закладену в неї полярність. Інтегруються в пошуку нових цікавих тем для дослідження не лише природничі дисципліни, знімається протиставлення природничих та гуманітарних знань. Гранична мета встановлення істини і побудова цілісної світоглядної конструкції, в центрі якої знаходиться вивчення взаємодії «людина-світ» - $є$ спільною для всіх можливих форм пізнання світу, їх колаборація відкриває перед людиною нові можливості у цьому напрямку.

В процесі свого становлення наука закріпила означені протиставлення як доконаний факт, зробила їх базовою передумовою власного наукового пошуку. Ключові постулати науки (насамперед, переконання у можливості та необхідності системного вивчення світу за допомогою розуму) почали формуватися в епоху Відродження та отримали своє теоретичне обгрунтування в добу Нового часу. Оскільки попередня концепція існування знань про світ як системи цілісного бачення, що диференціюється на раціональні та позараціональні концепти, потребувала радикального заперечення з метою позиціонування раціональної моделі світобудови як єдино правильної, традиція відмежування науки від культури, у лоні якої вона постала, не лише усталилася, але й закріпилася як шлях утвердження правильності всього нового. Як наслідок еталонності раціоцентричних моделей сприйняття світу, по-перше, науку почали наслідувати всі форми духовного освоєння світу (мистецтво, релігія, філософія), по-друге, кумулятивний поступ сприйняли як єдино можливий шлях накопичення та збереження знань. 
Окремі наукові дослідження кін. XIX - поч. XX ст. (теорія відносності, квантова теорія, принцип доповнюваності, синергетика та ін.) заклали підвалини для долання лінійності мислення і формування моделі множинного світу, діалоговість у якому є нормою співіснування.

Як наслідок, по-перше, нині активно відбуваються інтеграційні процеси у міждисциплінарному вимірі; по-друге, в рамках окремих наукових дисциплін (як природничих, так і гуманітарних) має місце активний пошук тяглости знань та встановлення поступальності наукового поступу.

При ретельному аналізі найбільш радикальні наукові теорії та принципово непримиренні мистецькі концепції постають як спадкоємці своїх попередників. Як зазначає С. Ягодзінський, «найрадикальнішу та найбільш популярну теорію А. Ейнштейна важко назвати інноваційною по відношенню до класичних теорій, оскільки їх збереження при вивченні електромагнітних та гравітаційних явищ і є предметом особливої турботи вченого. Змінившись для стороннього спостерігача, в цілому, принципи не змінилися відносно нової теорії, тип самим розширивши область свого застосування» [180]. «Наука, навіть постнекласична, зберегла в собі, в своїй основі ядро класичного типу наукової раціональності, та навіть більше - ніколи не відходила від нього впродовж всього етапу класичного, некласичного та постнекласичного природознавства. Вона лише пояснювала та адаптувала свої методи, математично-фізичний апарат під нові факти й гіпотези, а отже - хоча і $є$ нелінійною, розглядає нерівноважні, дисипативні процеси, все ж, по суті, залишається в рамках усталених традицій. Тому сучасний науковий дискурс слід розуміти правонаступником попереднього, в якому домінувала система детермінізованої логіки та строгої послідовності подій» [180]. Як бачимо, становлення науки має поступальний характер, а видима наявність протиріч між різними етапами їі розвитку знімається при більш детальному аналізі. Так само поступальним є розвиток гуманітарного знання.

Вивчення еволюційних процесів у культурфілософському середовищі підтверджує зазначену тенденцію. Зокрема, в рамках становлення західного 
типу філософування можна виявити тісні та глибоко укорінені взаємозв'язки різних епох між собою. Попри те, що доба Середньовіччя, яку Г. В. Ф. Гегель (Georg Wilhelm Friedrich Hegel) проголосив «прірвою людської історії», намагалася відмежуватися від здобутків попередньої епохи, вона базувалася на ученнях пізньої Античності (епікуреїзм, неоплатонізм, стоїцизм), а головним предметом власних духовних пошуків мала роздуми над теологією християнства, що як духовне вчення постало в попередню епоху. Становлення християнської теології було міцно пов'язане з філософськими рефлексіями над працями Платона (Plato) та Аристотеля (Aristotle), ідеї яких в добу панування схоластики стали теоретичною основою базових позицій у суперечці про універсалії для номіналістів та реалістів. Гуманісти Відродження так само войовниче сприймали доробок середньовіччя, хоча їх ідеї були продовженням думок середньовічних мислителів: теорії аверроїзму чи двоїстої істини I. Рушда (Ibn Rushd, Averroes); проголошення М. Кузанським (Nicholas of Kues and Nicolaus Cusanus)) Бога «безконечним максимумом», а природи «конечним максимумом», який доступний для пізнання людського розуму тощо. Доба Нового часу стала подальшим втіленням настанов гуманістів Відродження про діяльнісне покликання людини у світі, необхідність детального вивчення навколишнього світу, секуляризацію наукових знань, але й запереченням афористичності та поетичності викладу думки як норми написання наукових трактатів у попередню епоху. При цьому багато філософів доби Нового часу не лише тяжіли до поетичності викладу матеріалу, але й відстоювали думку про необхідність «об’єднання науки та поезії» (Ф. В. Шеллінг (Friedrich Wilhelm Joseph Schelling)). Критична оцінка доробку минулого загострилася на межі XIX-XX ст. Некласична філософія декларує необхідність перегляду світоглядних настанов не лише попередньої до неї епохи, але й усього напрацьованого людством загалом. Аксіологічні орієнтири некласичного світобачення є антитезою базових цінностей класичного філософування: культ розуму та науки (філософія Нового часу) - сумнів у принципах раціональності та системності (некласична філософія); переконаність у існуванні у світі істини 
та віра в можливість людини їі пізнати (філософія Нового часу) - онтологічний нігілізм, відмова від категорії «істина» (некласична філософія). Парадоксальним у цьому процесі є те, що некласичне філософування попри декларований ним скептицизм до наявних надбань людства стало втіленням тих принципів, які намагалася зреалізувати класична філософія. Насамперед, це настанова на пізнаваність світу, максимальне застосування раціонального пізнання на створення цілісної моделі світобудови. Некласична філософія за мету мала пізнання того, на що ii попередники наклали табу: пізнати позараціональні виміри наявного.

Історія становлення сучасних наук тяжіє до обгрунтування тяглості знань та перманентності наукового пошуку в межах окремо взятих наукових напрямків. А також до вияву взаємовпливів між науковими концепціями, що часто мають місце.

Перехресні наукові дослідження в рамках окремо взятих природничих та точних дисциплін вже давно відвоювали право на існування. Нагальною нині $є$ необхідність зняття протиріч між науковим (природничим) та гуманітарним знанням. Перше існувало у якості домінанти не лише наукових студій, але й мистецьких парадигм в епоху розвитку класичної науки та класичного мистецтва. Гуманітарне знання почало відстоювати свою самобутність та незалежність від природничо-наукового на межі кін. XIX - поч. XX ст., коли відбулася зміна світоглядних домінант на користь некласичного філософування. Це мало наслідком відмежування гуманітарного дискурсу від наукового, яке має характер лише видимого антагонізму, що знімається як аналізом становлення наукових студій, так і спостереженнями за культурномистецькою практикою.

Зазначена диференціація (на природниче та гуманітарне знання) сформувалася як наслідок опрацювання теоретичних постулатів Нового часу про необхідність вивчення світу та секуляризацію наукового знання. До філософії Нового часу, якщо і йшлося про відмінності «наук про природу» та «наук про дух», то лише 3 метою обгрунтування цілісності, яку формують 
взаємозв'язки між ними (про космогонічну цілісність світобудови писали античні мислителі, середньовічні містики шукали шляхів матеріального втілення духовних істин, романтики мріяли, як наука та мистецтво створять цілісність світу та знань, які напрацювало людство).

Антонімічне розмежування «наук про природу» та «наук про дух» започаткувала некласична філософська традиція. Виокремлення в окремий кластер «наук про дух» дозволяло, з одного боку, надати наукової атрибутики у вивченні тих аспектів існування світу та людини, які дотепер не були предметом вивчення, а, з іншого, - реабілітувати гуманітарне знання в умовах бурхливого розвитку природничих та технічних наук.

Протиставлення («наук про природу» та «наук про дух») було здійснено в працях філософів кінця XIX - поч. XX ст.: теоретика філософії життя В. Дільтея (Wilhelm Dilthey), представників Баденської школи неокантіанств В. Віндельбанда (Wilhelm Windelband) і Г. Ріккерта (Heinrich John Rickert). Метою цього розрізнення було обгрунтування епістемологічної самобутності та відстоювання самостійного статусу соціально-гуманітарних дисциплін, предмет вивчення та методологія яких відмінні від природничо-наукових. Протиставлення згодом змінилося на розмежування, часто непримиренного характеру, в науковому дискурсі XX ст., яке піддає сумніву як сучасна наука, так і практика щоденного життя людини XXI ст.

У середині XX ст. питання порівняння гуманітарних та природничих наук та усталеної в їх рамках відповідної наукової методології отримало новий вектор обговорення у зв’язку з публікацією книги американського дослідника Ч. Сноу (Charles Percy Snow) «Дві культури». Дослідник застерігає від принципового розмежування соціально-гуманітарного та природничонаукового знання та відповідних їм сфер діяльності в сучасному світі, вказує на небезпеку такого розмежування, а також зазначає, що діалог між ними є єдино продуктивним шляхом розвитку. «Зіткнення двох дисциплін, двох систем, двох культур, двох галактик - якщо не боятися зайти так далеко! - не може не висікти творчої іскри. Як видно з історії інтелектуального розвитку людства, такі іскри 
дійсно завжди спалахували там, де розривалися звичні зв’язки. Зараз ми знову покладаємо наші творчі надії передусім на ці спалахи» [181].

Думки про шкідливість розмежування природничо-наукового та гуманітарного знання висловлював також французький філософ О. Койре (Alexandre Koyre). Хоч наука має справу з кількістю як категорією, що фіксує різноманітність світу, а культура (як уособлення гуманітарного знання) 3 якістю, наука та культура між собою тісно переплетені. Так, наукова думка завжди поставала в середовищі інтелектуалів того чи іншого часу, яких хвилювали не лиже теоретичні пошуки у певній галузі, але й світоглядні проблеми, що були предметом якнайширшого обговорення; а великі наукові революції в історії людства завжди мали наслідком зміну філософських концепцій [182].

Англійський фізик і філософ науки М. Поланьї (Michael Polanyi) розробив концепцію «неявного знання», яка підтверджує викладені міркування про синкретичну єдність природничо-наукового та гуманітарного знань. Як зазначають дослідники, «неявне знання не отримало чіткого категоріального визначення. Але воно відіграє важливу роль у формуванні і відтворенні спонтанного порядку в багатьох сферах життя» [183]. Разом 3 тим, підтвердження наявності «неявного знання» можна віднайти у багатьох аспектах як побутового життя (коли знання неначе іманентно та імпліцитно присутнє в нас, ми володіємо ним без спеціального опанування), так і в дослідженні історії наукових розробок (значну частину яких науковці пов’язують з інсайтом, що не лише позбавлений видимої причини, але й часто пов’язаний зі станом позасвідомого, наприклад, сну).

Головна особливість цього знання у тому, що «людина, яка в певних умовах може скористатися неявним знанням не знає, що вона це знання має.» [184]. «Ми ясно усвідомлюємо обсяг, специфіку нашого знання, правда, навряд чи уявляємо собі його в деталях» [184]. «Для мене знання, - пише М. Поланьї, - це активне осягнення пізнаваних речей, дія, що потребує особливого 
мистецтва» [184]. Дослідник зазначає: «Внаслідок мовчазного характеру нашого знання ми ніколи не можемо висловити все, що знаємо» [184].

Дихотомія, що закладена в основу пізнання як поєднання його емпіричного та теоретичного, раціонального та позараціонального складників «скасовується, коли ми пізнаємо один той же предмет двома різними способами, які не можуть бути поєднані один з одним за допомогою логічних операцій, але можуть бути встановлені шляхом дослідження сократичного типу» [184].

Австро-британський економіст і філософ Ф. Хайєк (Friedrich August von Hayek) позначав неявне знання, про яке писав М. Поланьї, як розсіяне, неповне та незавершене. «Конкретне знання, яким керується в своїх діях будь-яка група людей, ніколи не існує як внутрішнє суперечливе і узгоджене ціле. Воно існує тільки в розсіяному, неповному і неузгоджену вигляді, в якому воно і перебуває в багатьох індивідуальних умах, і від неуважності і недосконалості будь-якого знання як від двох основоположних фактів повинні відштовхуватися соціальні науки. Те, від чого філософи і логіки часто з презирством відвертаються як від «простої» недосконалості людського розуму, для соціальних наук $\epsilon$ вирішальним, центральним фактом» [185]. Філософ не лише відстоює цю точку зору, але зазначає шкідливість протилежної до неї позиції: «протилежна «абсолютистська» точка зору - ніби знання, і перш за все конкретні знання особливих обставин, постають перед нами «об'єктивно», тобто неначе однаковими для всіх людей, $-\epsilon$ в соціальних науках джерелом постійних помилок» [185].

Ф. Хайєк зазначає, що первинною формою існування знань в історії людства було не наукове, а особистісне знання: «на початку свого шляху Науки повинні були пробивати собі дорогу в світі, де основою для наших уявлень були здебільшого наші відносини з іншими людьми і тлумачення їх вчинків. Цілком природно, що в процесі цієї боротьби Наука, яка розвинула швидкість, могла проскочити через межу і створити нинішню ситуацію, коли небезпечним стало, навпаки, панування саєнтизму, що заважає прогресу в пізнанні суспільства» [185]. 
Якщо ж науковець має на меті мати дійсно наукове гуманітарне знання, він має звернутися до вивчення цього розсіяного знання: «Завдання, що постає перед тим, хто має своїм завданням раціонально влаштовувати суспільство, знайти спосіб найкращим чином збирати це широко розсіяне знання» [185].

Дія у відповідності з окресленими напрямами інтеграційних процесів сучасності має стати підгрунтям модернізації освіти на всіх їі рівнях (дошкільна, загальна середня, професійно-технічна, фахова передвища, вища освіта), у всіх формах здобуття (інституційній, індивідуальній, дуальній) та видах (формальній, неформальній, інформальній). Особливе місце в процесі цього оновлення посідає вдосконалення системи вищої освіти відповідно до вимог часу, оскільки це саме той освітній рівень, який відповідає за репродукування знань в суспільстві.

Інновації, які покликані змінити систему сучасної освіти у напрямку формування цілісної освітньої моделі як найбільш сприятливої для розкриття потенціалу особистості, мають бути спрямовані за наступними напрямками:

• Формування інноваційного освітнього простору навчального закладу 3 метою створення особистісного інноваційного простору як середовища для реалізація концепту «освіта впродовж життя».

•Встановлення якнайширших міждисциплінарних зв'язків в процесі викладання дисциплін загальної та професійної підготовки. Це не лише розвиває навички критичного мислення, але й розширює світогляд, формує його як цілісний конгломерат знань, що мають ціннісний вимір засвоєння особистістю.

-Впровадження інноваційних мультидисциплінарних дидактичних комплексів на рівні бакалаврської, а особливо магістерської підготовки та підготовки докторів філософії (PhD). Такі навчальні комплекси дозволяють не лише запропонувати новітні поєднання дисциплін для їх вивчення студентами, але й формують у них здатність до перекомпонування вже набутих знань, до пошуку нових перехресних зв'язків. STEM-орієнтований підхід до навчання формує гнучкість, дивергентність мислення, розвиває всі рівні множинного 
PEDAGOGY IN MODERN CONDITIONS

інтелекту особистості (Г. Гарднер (Howard Gardner)) [186]. Важливим напрямком створення таких комплексів $є$ гуманізація змісту природничої освіти та забезпечення реалізації природничо-наукового складника в освіті гуманітаріїв (фундаменталізація освіти).

-Широке залучення в робочі програми навчальних дисциплін самого різноманітного змісту (як теоретичного, так і практичного характеру) такого виду навчальної роботи як створення інноваційного проєкту. Проєктна робота формує навички командної праці, колаборації, базові soft skills, емоційний інтелект (EQ) (Д. Гоулман (Daniel Goleman) [187]), а також орієнтує на отримання практично орієнтованих знань в процесі проблемно-орієнтованого навчання.

Реалізація в сучасній освіті зазначеного синергетичного підходу має на меті формування інноваційно освіченої особистості, що здатна на творення нового в нелінійному вимірі сучасності, що здатна до усвідомлення та активної дії в напрямку впровадження іiі (сучасності) провідних тенденцій. 


\section{7 Дослідження ефективності впливу графічного дизайну на сприйняття навчального матеріалу}

Прогрес людства неможливий без уміння ефективно сприймати, запам’ятовувати та відтворювати нові знання. Друковані видання використовують як основні або додаткові джерела інформації під час навчання.

Сучасні тенденції дизайну, вподобання молодого покоління та прогресивність методів навчання диктують певні умови для оформлення навчальних посібників та підручників. Молодь не дуже зацікавлена у старомодних сторінках $з$ текстом - упереджений образ нецікавого підручника сприяє зниженню інтересу до дисципліни загалом. Соціальні дослідження показують низький рівень ефективності сприйняття та засвоєння навчального матеріалу серед здобувачів вищої освіти [187].

Необхідним стає підвищення ефективності засвоєння матеріалу за допомогою розроблених рекомендацій щодо дизайну та графічного оформлення сучасних навчальних видань для закладів вищої освіти.

Основною проблемою дизайну спеціалізованих видань є погіршення якості сприйняття при застосуванні сучасних авангардних прийомів верстки [188] та графічного оформлення. При різноманітності навчальної літератури [189] - від одноколірних методичних вказівок - до повнокольорових підручників та наочних посібників, необхідно сформувати загальні вимоги до дизайну.

Можна виділити спільні риси у поставлених вимогах та тенденціях сучасного дизайну. Простота, лаконізм, логічна та доцільна декоративність, чіткість конструкції всіх елементів оформлення, пропорції смуги набору і полів, контрастні співвідношення, застосування «вільного» незадрукованого простору в загальній композиції, якісні ілюстрації та ін. Течії дизайну 20-го століття, які стають передовими для натхнення сучасників, підкреслюють типографіку, шрифти без зарубок, геометричні форми, прості лінії, об’єм і колір. Розроблені рекомендації щодо дизайну повинні не тільки допомагати приваблювати та зацікавлювати сучасного здобувача освіти, а й сприяти більш ефективному 
PEDAGOGY IN MODERN CONDITIONS

засвоєнню матеріалу. Обрано такі критерії оцінки навчального видання [189, 190]:

- привабливість дизайну;

- чіткість візуального сприйняття структури;

- легкість сприйняття тексту;

- ефективність запам’ятовування матеріалу [191].

Для обгрунтування вибору рекомендованих прийомів верстки та графічного оформлення друкованих видань, виявлення переваг та недоліків їх застосування відповідно до поставленої мети було проведено опитування студентів різних вищих навчальних закладів.

Для опитування були розроблені: питання щодо переваг того чи іншого прийому верстки та дизайну; тестові зразки верстки та оформлення навчальних видань [192], які не призначені для детального розгляду і дозволяють оцінити загальний виклад матеріалу 3 характерними особливостями; спеціальні зображення для перевірки оперативного сприймання інформації та ii запам’ятовування; використано сторінки розглянутих аналогів.

Кожне питання опитування наслідує певні прийоми, що виділені у переліку критеріїв для оцінки видання на предмет ефективності засвоєння матеріалу. Загальна структура опитування та смислове наповнення кожного питання розроблені на основі наукової інформації щодо сприйняття та засвоєння інформації людиною, позиції логіки зі сторони респондентів, психологічних характеристик цільової аудиторії, емоційної складової формулювання питання.

По першому критерію отримано наступні результати (мал.1):

- майже однакові показники щодо переваг використання спокійних кольорів оформлення і яскравих кольорів обкладинки;

- суттєву перевагу віддали зразку з графічним кольоровим оформленням;

- майже стовідсотковий показник демонструє бажання аудиторії користуватися виданнями, що виглядають сучасно та цікаво. 


\section{PEDAGOGY IN MODERN CONDITIONS}

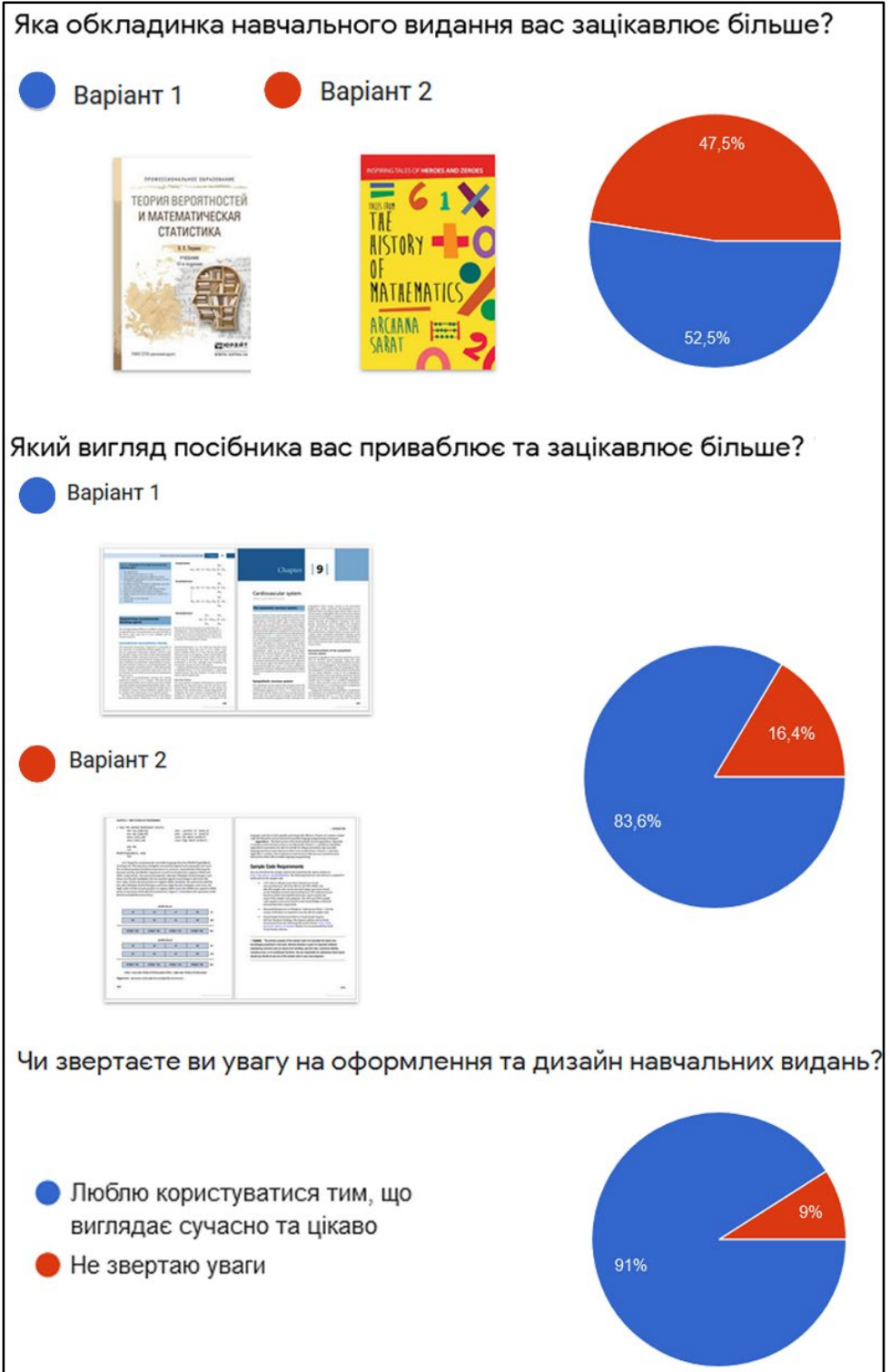

Малюнок 1. Результати опитування щодо першого критерію.

Визначено пріоритетність та теоретичну ефективність застосування певних прийомів. Найбільшу увагу сучасних здобувачів освіти в оформленні навчальної літератури привертає: цікаве розташування тексту та зображень; приємна колірна гама з 2-3 кольорів; інфографіка замість великої кількості тексту (мал.2).

В наступних елементах опитування пропонувалося обрати більш легший для сприйняття матеріал. Ключовим $є$ те, що зразки містять ідентичний текст, але це не відомо для респондентів. Представлені матеріали демонструють вплив структури та верстки на характер сприйняття інформації (мал.3). 


\section{PEDAGOGY IN MODERN CONDITIONS}

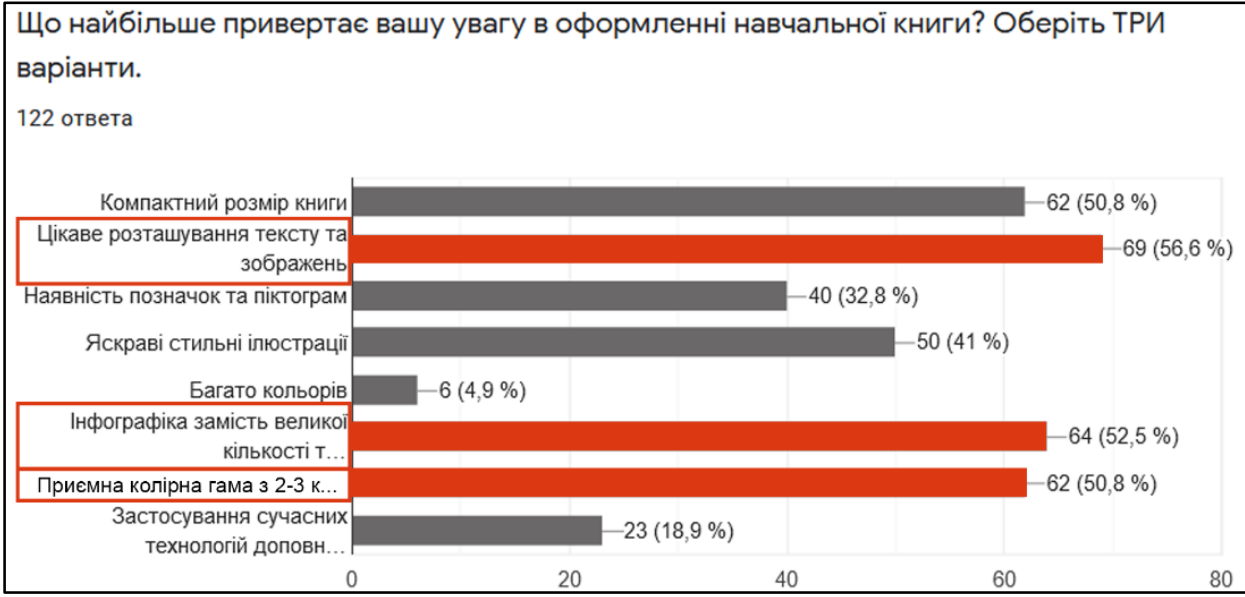

Малюнок 2. Ефективність застосування прийомів дизайну та верстки.

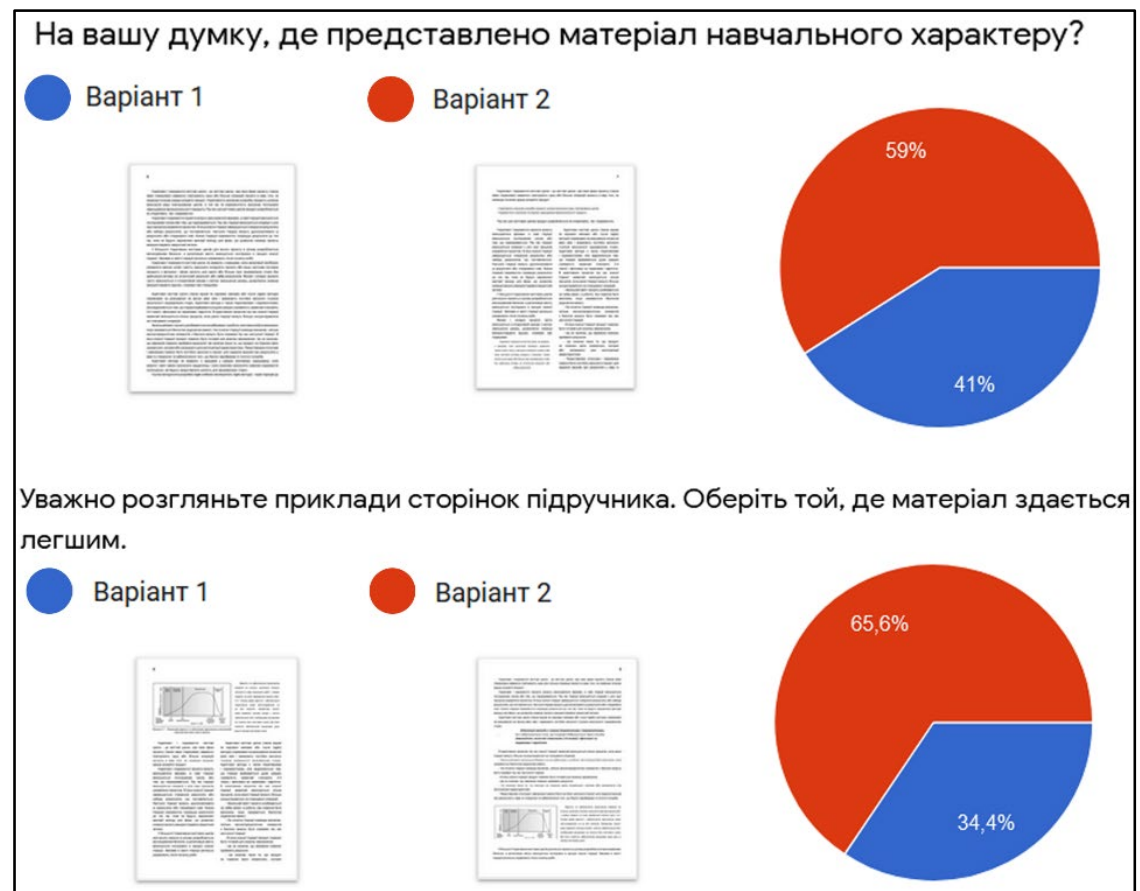

Малюнок 3. Результати опитування щодо другого критерію.

Результати перевірки критерію щодо легкості сприйняття тексту представлено на мал. 4:

- ідентичний матеріал 3 різним вирівнюванням основного тексту сприймається по-різному. Респонденти надали майже стовідсоткову перевагу варіанту з плавною флаговою версткою;

- не виявлено суттєвої переваги використання шрифту із зарубками над рубаним за умови збільшення інтерліньяжу у останньому випадку; 


\section{PEDAGOGY IN MODERN CONDITIONS}

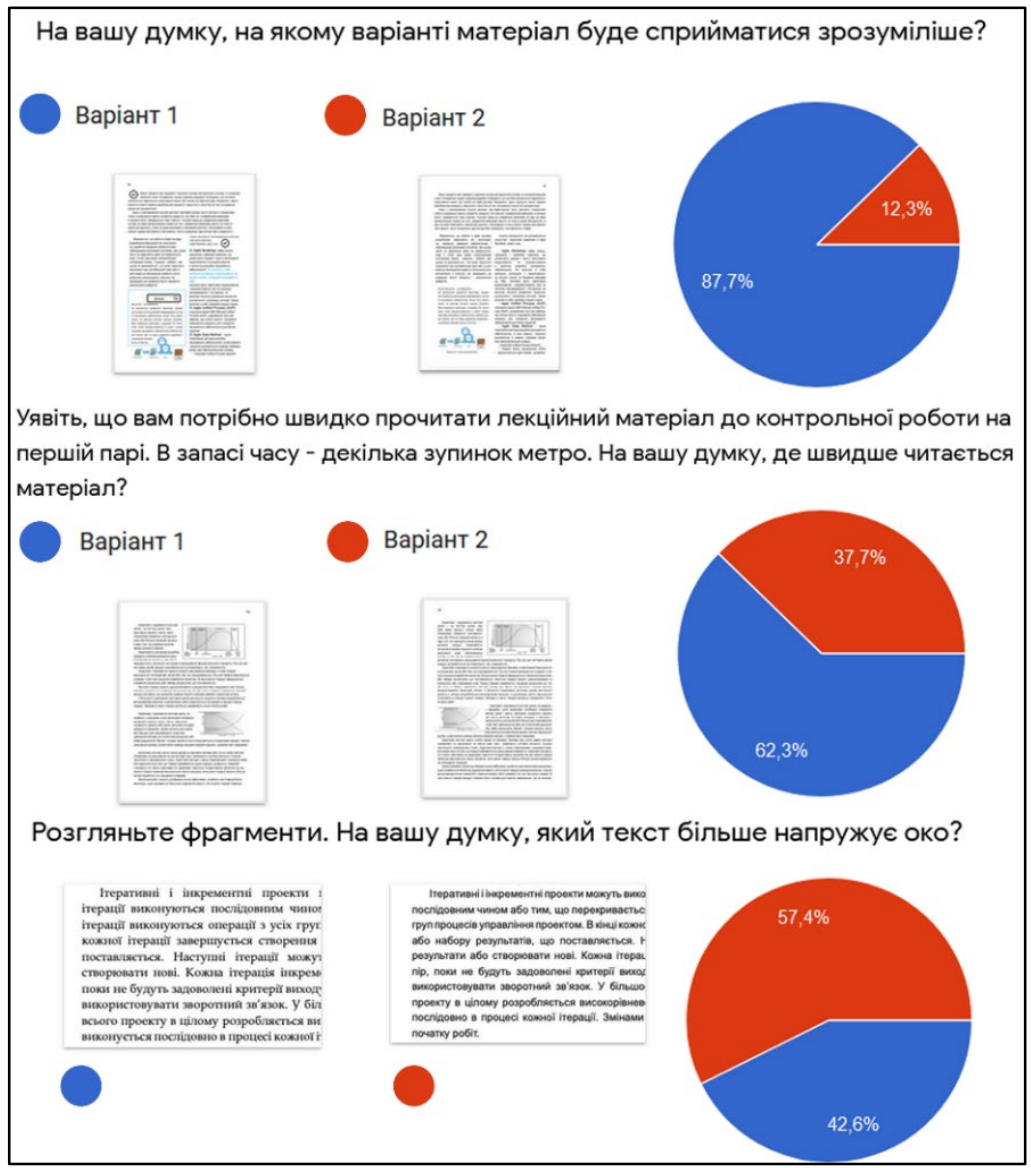

Малюнок 4. Результати опитування щодо третього критерію.

- ідентичний матеріал 3 різною структурою верстки сприймається порізному. Респонденти надали невелику перевагу варіанту 3 блоковою структурою та виділенню основного за допомогою вільного простору;

- більша половина опитаних засвідчила, що більш швидко та плавно переміщується погляд у варіанті з флаговою версткою.

Аналіз результатів перевірки засвоєння матеріалу $є$ одним 3 найбільш змістовних для розробки майбутніх рекомендацій (мал.5.).

Респондентам було запропоновано швидко ознайомитися зі змістом ( 30 секунд). Елемент опитування встановлює ігровий момент, азарт опитуваного. Змістом є представлення спрощеного фрагменту навчального матеріалу. Ключовим моментом є те, що опитуваний не знає мети споглядання, а при натисканні на кнопку «Розглянув» переходить на наступний розділ та нову сторінку з проханням позначити слова, які запам'яталися 3 попередньої сторінки найбільше. 


\section{PEDAGOGY IN MODERN CONDITIONS}

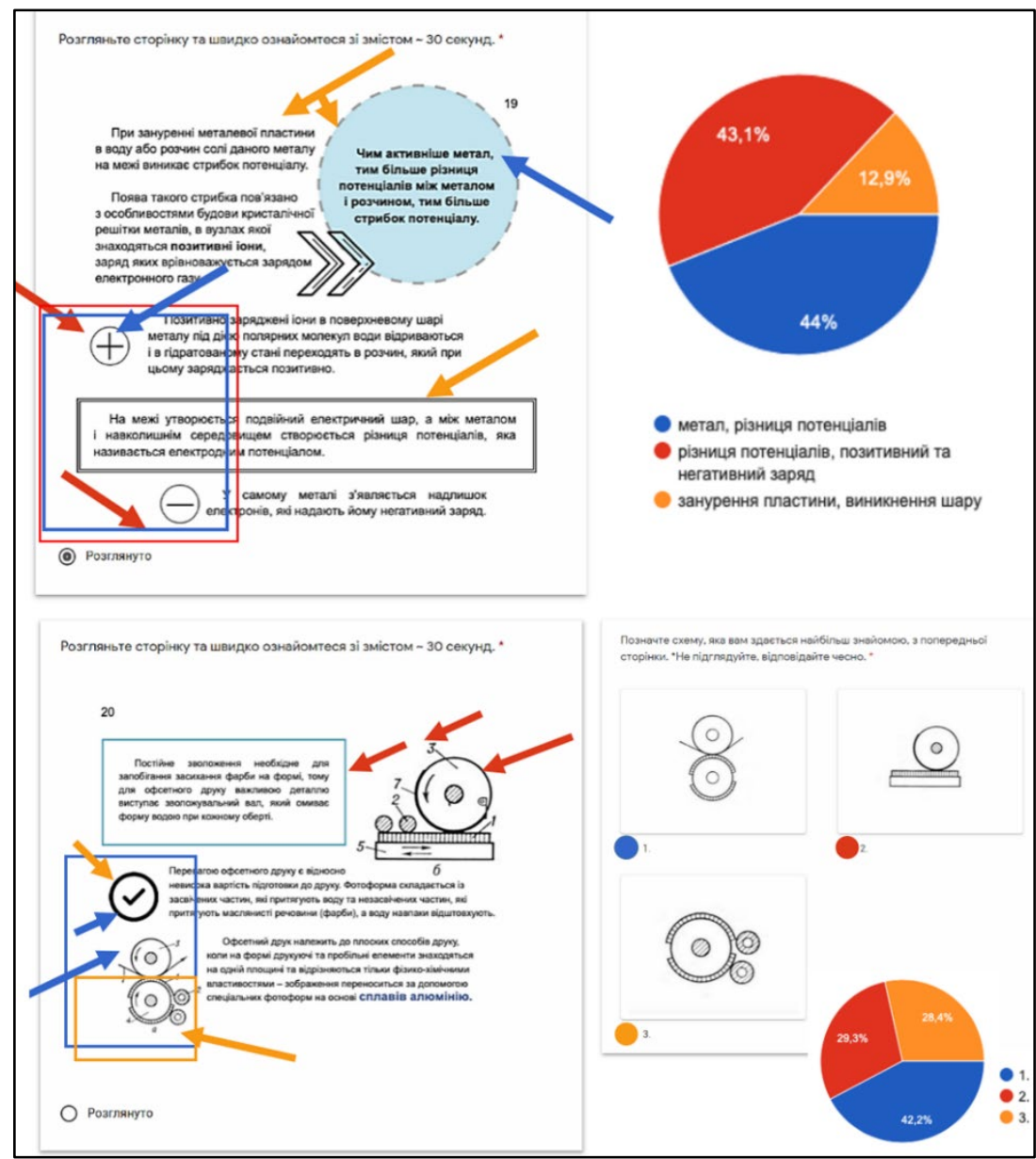

Малюнок 5. Результати опитування щодо четвертого критерію.

Варіанти відповідей по-різному підтверджують ефективність застосування засобів графічної виразності: кольору, піктограм або їх сполучення для акцентування і як наслідок, ефективного запам'ятовування. Окремим випадком $€$ здатність асоціативної пам'яті згадати інформацію, яка була представлена графічно, а не тільки текстом. Фокус миттєвої уваги не тільки перевтілює графічну інформацію у текстову, а і сприяє запам'ятовуванню тексту поряд.

Під час розгляду останнього зразка респондент вже знає «мету» споглядання, намагається запам'ятати ключові поняття, але надлишок термінів та певна предметна спрямованість заважає швидко сконцентруватися. При переході на наступну сторінку з питанням опитуваному пропонується позначити не слова, а схему з попередньої сторінки, яка запам'яталася найбільше, на рівні підсвідомої зорової пам'яті. При цьому перевіряється засвоєння не текстової інформації, а ілюстративної, адже схеми і графіки є популярним наповненням 
навчальної літератури. Задля полегшення умов, схеми було спрощено на законах сприйняття графіки, пропущені дрібні деталі.

Варіанти відповідей по-різному підтверджують ефективність застосування засобів графічної виразності. Піктограми беруть на себе найбільший фокус засвоєння інформації, навіть при умові ускладненого розташування в нижній частині сторінки. Рамка для виділення підвищує ефективність сприйняття ілюстративної інформації, яка розташована поряд. Виявлено негативний вплив надмірного фокусу уваги за допомогою піктограми та пригнічення запам'ятовування інших елементів.

На основі повного аналізу та отриманих даних з експерименту розроблено рекомендації щодо дизайну навчальних видань для ефективного сприйняття та засвоєння матеріалу:

- загальна концепція дизайну видання не повинна поєднувати велику кількість графічних стилей, різнорідних елементів, які характерні для протилежних концепцій;

- структура основного тексту має чітко сприйматися візуально, бути логічною, з витриманими пропорціями;

- основні та додаткові тексти повинні чітко сприйматися - змістовно та візуально, можуть розрізнятися за шрифтовим рішенням;

- шрифт основного тексту повинен полегшувати сприйняття матеріалу;

- ілюстративний матеріал має бути сучасним, тематично різноманітним;

- використання спеціально створеного ілюстративного матеріалу для конкретного видання, що наслідує загальну концепцію дизайну;

- обмежене, за можливості, використання фотографій. Якісне фото, як правило, містить багато зайвих елементів, складно поєднується 3 іншими засобами графічної виразності;

- використання умовних позначок та додаткових графічних елементів. Вони повинні чітко розрізнятися візуально, узгоджуватися зі змістом їх призначення; 
- використання візуального представлення інформації у поєднанні тексту на графіки (інфографіки);

- доцільне використання декоративних елементів, щоб не перевантажувати смугу набору пістрявістю, яка розсіює увагу;

- розміщення QR-кодів з посиланням на додаткові джерела, інформацію, що неможливо представити у друкованому варіанті або для зменшення обсягу;

- для збільшення наочності та інтерактивної взаємодії з друкованим виданням рекомендовано використання технологій доповненої реальності за наявності можливостей науково-методичної бази.

Рекомендується ознайомлення 3 повним переліком сучасних прийомів графічної виразності та їх призначенням (табл.1).

Таблиця 1.

Перелік рекомендованих прийомів та засобів дизайну.

\begin{tabular}{|c|c|}
\hline Прийом або засіб & Призначення \\
\hline Ідання & $\begin{array}{l}\text { Наближення пропорцій ширини та висоти видання до квадрату може позитивно } \\
\text { вплинути на процес верстки та забезпечити ефективне застосування інших } \\
\text { графічних засобів. }\end{array}$ \\
\hline $\begin{array}{l}\text { Лінійна } \\
\text { послідовність }\end{array}$ & $\begin{array}{l}\text { Матеріал сприймається зліва-направо, зверху-вниз. Запам’ятовується } \\
\text { ефективніше права верхня сторона. Для постійної активізації фокусу уваги на } \\
\text { проблемну частину, доцільно змістити складну текстову інформацію вниз. }\end{array}$ \\
\hline $\begin{array}{l}\text { Асиметрія, } \\
\text { гармонійна } \\
\text { абстракція }\end{array}$ & $\begin{array}{l}\text { Надає можливість вільно управляти структурою та напрямом руху зору при } \\
\text { сприйнятті інформації. Допомагає визначати важливі взаємозв’язки між } \\
\text { структурними частинами тексту, починаючи з різних кутків модуля. Основні та } \\
\text { додаткові тексти повинні розрізнятися, і змістовно, і візуально. }\end{array}$ \\
\hline $\begin{array}{l}\text { Активний } \\
\text { «вільний простір» }\end{array}$ & $\begin{array}{l}\text { Структурує макет і виділяє важливі деталі. Ефективний інструмент для } \\
\text { збалансування елементів і організації контенту. Покращує візуальні зв'язки між } \\
\text { модулями. Між основними смисловими блоками контенту, оточує всі елементи } \\
\text { та управляє фокусом уваги читача. Між рядками і абзацами заспокоює і дає } \\
\text { можливість оку не стомлюватись при швидкому переміщенню. }\end{array}$ \\
\hline Колонки & $\begin{array}{l}\text { Рекомендована кількість колонок - 2, привідна верстка. Доцільно застосовувати } \\
\text { для навчального матеріалу без можливості поділу на структурні елементи. Для } \\
\text { полегшення сприйняття основного тексту рекомендується чергування } \\
\text { текстового та графічного матеріалу в межах однієї колонки та сусідніх. }\end{array}$ \\
\hline
\end{tabular}


Продовження Таблиці 1.

\begin{tabular}{|c|c|}
\hline Прийом або засіб & Призначення \\
\hline $\begin{array}{l}\text { Вирівнювання } \\
\text { основного тексту } \\
\text { вліво }\end{array}$ & $\begin{array}{l}\text { Усуває надлишок геометричних форм загального дизайну. Занадто рваний край } \\
\text { та висячі рядки - руйнують форму текстового блоку, заважають сприйняттю } \\
\text { інформації. }\end{array}$ \\
\hline $\begin{array}{l}\text { Вирівнювання } \\
\text { основного тексту } \\
\text { по ширині }\end{array}$ & $\begin{array}{l}\text { Сприймається зором як прямокутник, ускладнює рух ока по рядками при } \\
\text { довготривалому читанні, сприяє виникненню небажаних «коридорів». Обмежує } \\
\text { використання асиметричної структури та гармонійного поєднання тексту та } \\
\text { графічних елементів. Доцільно для набору невеликих блоків тексту, визначень, } \\
\text { правил, виносок тощо. }\end{array}$ \\
\hline $\begin{array}{l}\text { Шрифти без } \\
\text { зарубок }\end{array}$ & $\begin{array}{l}\text { Якісно сприймаються при різному кеглі, якісніше сприймаються при перегляді } \\
\text { електронної версії. Доцільно у випадку тексту на кольоровому фоні, коли текст } \\
\text { дрібний або вузький. Рекомендується збільшення інтерліньяжу. }\end{array}$ \\
\hline $\begin{array}{l}\text { Шрифти } \\
\text { iз зарубками }\end{array}$ & $\begin{array}{l}\text { Зарубки збільшують контраст між буквами і роблять їх швидше пізнаваними. } \\
\text { Направляють рух очей уздовж рядків при читанні великих масивів друкованого } \\
\text { тексту при вирівнюванні по ширині. }\end{array}$ \\
\hline Фотографії & Рекомендується використовувати при повнокольоровому друці. \\
\hline Схеми та графіки & Особливо доцільні при обмеженні фарбовості видання. \\
\hline $\begin{array}{l}\text { Авторські } \\
\text { ілюстрації }\end{array}$ & $\begin{array}{l}\text { Рекомендується узгодження стилю розроблюваних ілюстрацій з іншими } \\
\text { графічними засобами виразності. Вдалий підбір колірної гами та стиль } \\
\text { зображень ефективно посилює емоційне сприйняття інформації та загальне } \\
\text { враження. Приваблюють аудиторію молодого покоління, використовуються для } \\
\text { залучення уваги, , наповнюють видання єдиним стилем. }\end{array}$ \\
\hline Інфографіка & $\begin{array}{l}\text { Ефективний спосіб візуального представлення інформації у поєднанні тексту на } \\
\text { графіки. Дозволяє швидко усвідомлювати і розуміти та запам’ятовувати складну } \\
\text { і нову інформацію. }\end{array}$ \\
\hline $\begin{array}{l}\text { Додаткові } \\
\text { графічні елементи }\end{array}$ & $\begin{array}{l}\text { Забезпечують наявність постійного акцентування зору, виділення важливого, } \\
\text { посилюють емоційний зміст дизайну. Доцільно використання піктограм, } \\
\text { позначок, стрілок, дудлів. }\end{array}$ \\
\hline QR-коди & $\begin{array}{l}\text { Двовимірне зображення, для розпізнавання сканувальним обладнанням (в тому } \\
\text { числі і фотокамерою мобільного телефону). Доцільно застосовувати для } \\
\text { переходу за посиланням на додаткові літературні джерела та інтернет-ресурси, } \\
\text { приклади завдань, періодично оновлювану ілюстративну базу тощо. }\end{array}$ \\
\hline $\begin{array}{l}\text { Доповнена } \\
\text { реальність }\end{array}$ & $\begin{array}{l}\text { Проектування цифрової інформації (зображення, відео, текст, графіка і т.д.) } \\
\text { поверх екрану будь-яких пристроїв. В результаті сторінки книги доповнюються } \\
\text { штучними елементами і новою інформацією. Може бути реалізована за } \\
\text { допомогою додатків до звичайних смартфонів. }\end{array}$ \\
\hline
\end{tabular}




\section{PEDAGOGY IN MODERN CONDITIONS}

Дизайнер може безпосередньо використовувати рекомендовані прийоми та видозмінювати їх характеристики, відповідно до власної концепції.

Удосконалення взаємозв'язку змісту, структури з графічним оформленням підручника або посібника є одним з найважливіших завдань сучасної освіти. Врахування запропонованих рекомендацій дизайнерами сприятиме модернізації сучасної навчальної літератури. 


\section{8 Навчання фахівців-поліграфістів за допомогою тренажера офсетного друку}

Одним із найголовніших напрямів розвитку освіти $\epsilon$ впровадження мультимедійних електронних видань, що забезпечить подальше вдосконалення навчально-виховного процесу.

Істотний внесок в підвищення якості електронних видань для вищої професійної освіти вносить впровадження в видання програм-тренажерів, заснованих на інтерактивній машинній графіці. Відомо, що швидкість сприйняття інформації, представленої в графічному вигляді якісніше, ніж швидкість читання і осмислення текстових даних [192].

Електронне видання повинно надати друкарям-початківцям базовий теоретичний матеріал, допомогти набути практичних навичок і підштовхнути до подальшого вивчення і практичних занять на друкарському обладнанні.

Потенційних користувачів електронного видання умовно можна розділити на наступні групи:

а) освітні установи вищої професійної освіти;

б) освітні установи середньої професійної освіти;

в) приватні організації поліграфічного виробництва.

Можна виділити наступні категорії споживачів:

I - викладачі освітніх установ;

II - студенти, які вивчають дану галузь;

III - практиканти організацій поліграфічного виробництва.

Основні причини, що зумовлюють необхідність використання програмитренажера:

a) тренажер дозволить заощадити матеріальні витрати, пов'язані 3 навчанням;

б) доступ до інформації, розміщеної в мережі Інтернет, дозволяє отримувати нові дані про дефекти друку для різних листових машин, типів паперів, фарб і технологічних режимах роботи листових офсетних друкарських машин; 


\section{PEDAGOGY IN MODERN CONDITIONS}

в) після аналізу видів друкарського обладнання, наявного на певному підприємстві і характеру дефектів, що виникають при друці, можливе внесення цих даних в тренажер;

Позитивний ефект від використання програми-тренажера обумовлений такими факторами:

a) спочатку учасник навчально-виховного процесу, працюючи 3 тренажером, сприймає друкарську машину як деякий об'єкт комп'ютерної гри, який в разі невдачі дозволяє почати «гру» - тестування заново, а не отримати невтішні висновки про свою роботу;

б) освоївши тренажер, учасник навчально-виховного процесу проходить тестування з усіх систем друкарської машини і автоматично отримує висновок про свої досягнення;

в) аналіз результатів тестування виявляє «слабкі місця» в отриманих знаннях i навичках, на які учасник навчально-виховного процесу звертає пильнішу увагу при подальшому тестуванні;

г) виконавши успішно всі завдання програми-тренажера, випускник усвідомлено і в короткі терміни зможе адаптуватися на виробництві.

Важливе теоретичне й практичне значення вказаних проблем та їх невирішеність зумовили необхідність проведення цього дослідження.

Методика навчання і тренування 3 використанням тренажерів дозволяє більш різнобічно підготувати і навчити друкарів і технологів галузі до того, як їм на практиці в реальних умовах виробництва доведеться зіткнутися зі всілякими проблемами. Тренажер допоможе друкареві підвищити свій розряд, а студенту-поліграфісту - здати іспит.

Проблема використання програм-тренажерів в навчальному процесі для підвищення рівня теоретичних знань i практичних навичок студентів розглядалася в роботах [195-197]. Програма-тренажер офсетної листової друкарської машини повинна будуватися на основі «блочного» підходу формування інформації, коли кожен блок визначається деяким етапом навчання 
учасника навчально-виховного процесу. Структура програми-тренажера повинна включати:

а) блок №1 - інформація про наладку та приладку розглянутого устаткування, про несправності, їх причини та способи усунення;

б) блок №2 - тестування для оцінки якості засвоєння матеріалів;

в) блок №3 - оцінка якості засвоєння матеріалів;

г) блок №4 - завдання для оцінки якості засвоєння матеріалів;

д) блок №5 - оцінка правильності виконаного завдання.

У складі блоку №1 розміщується така інформація: принцип дії i послідовність підготовки обладнання i його систем до роботи, можливі несправності та способи їх виправлення. Потім принцип дії кожного $з$ пристроїв окремо і устаткування цілком подаються в динаміці за допомогою відеофільмів. Студент, відкривши цей розділ, повинен почати вивчення матеріалів в рекомендованій послідовності. Цей же принцип закладений в організацію тренажера в цілому.

Блок №2 містить перелік тестів для оцінки якості засвоєння матеріалу, який включено до складу блоку №1. У системі тестуваняя учасник навчальновиховного процесу повинен вказати максимальну кількість причин дефекту iз загальної маси поданої йому інформації. Такий підхід дозволить сформувати у нього уявлення про кожну з систем машини, можливі дефекти в системі, причини та способи їх виникнення та усунення. Файлова система дозволить студентам після первинного тестування самим визначати свої «слабкі» місця і вибирати тест для повторного тестування і відповідні їм матеріали з блоку №1.

Блок №3 містить інформацію про оцінку виконаних тестів. Особливістю його в порівнянні з блоком №1 та блоком №2 є «персоналізація» даних - робота кожного студента 3 системою повинна фіксуватися окремо. Оцінювання результату підготовки на цьому етапі проводиться за кількістю обраних причин, а також по повторюваності результатів при неоднократному проходженні даного тесту. Таким чином, створюється система оцінювання як коректності самого 


\section{PEDAGOGY IN MODERN CONDITIONS}

тесту, так і процесу засвоєння матеріалу, що дозволить при необхідності внести зміни в структуру і склад інформації тесту.

Блок №4 дозволяє імітувати процеси, що протікають в досліджуваних реальних об'єктах. При цьому тренажер імітує не тільки реальну офсетну друкарську машину, але і об'єкти дослідження і умови роботи на друкарському обладнанні. Тренажер формується в такому порядку: вид обладнання; загальний принцип дії; принцип дії і підготовка обладнання до роботи; підготовка до роботи кожної з систем, що входять до складу обладнання із зазначенням виду індикації (або інших ознак) про стан готовності кожної 3 систем; опис можливості підготовкою до роботи систем з панелі управління машини, опис ознак готовності машини до роботи в цілому.

При роботі з тренажером складається перелік ситуацій-станів вузлів і механізмів машини, які можуть викликати дефекти друкування, і в відповідність їм ставляться дефекти; на другому етапі аналізуються при експлуатації дефекти друкування, встановлюють їх причини, усувають їх і перевіряють результат дефекти не повинні повторюватися. Це дозволяє скласти перелік можливих дефектів друкування і причин, усунення яких дозволив уникати дефектів або попереджати їх.

Тренажер має наступну структуру - на екрані монітора короткий опис системи, що вивчається (мал.1.); далі набір «вікон», в кожному з яких вказані поля для введення даних після «друкування», набір «вікон» вид дефекту i причини його виникнення (мал.2.). Працюючи 3 тренажером, стажист знайомиться 3 описом системи, потім 3 дефектом, причинами його виникнення i визначає спосіб його усунення. 


\section{PEDAGOGY IN MODERN CONDITIONS}

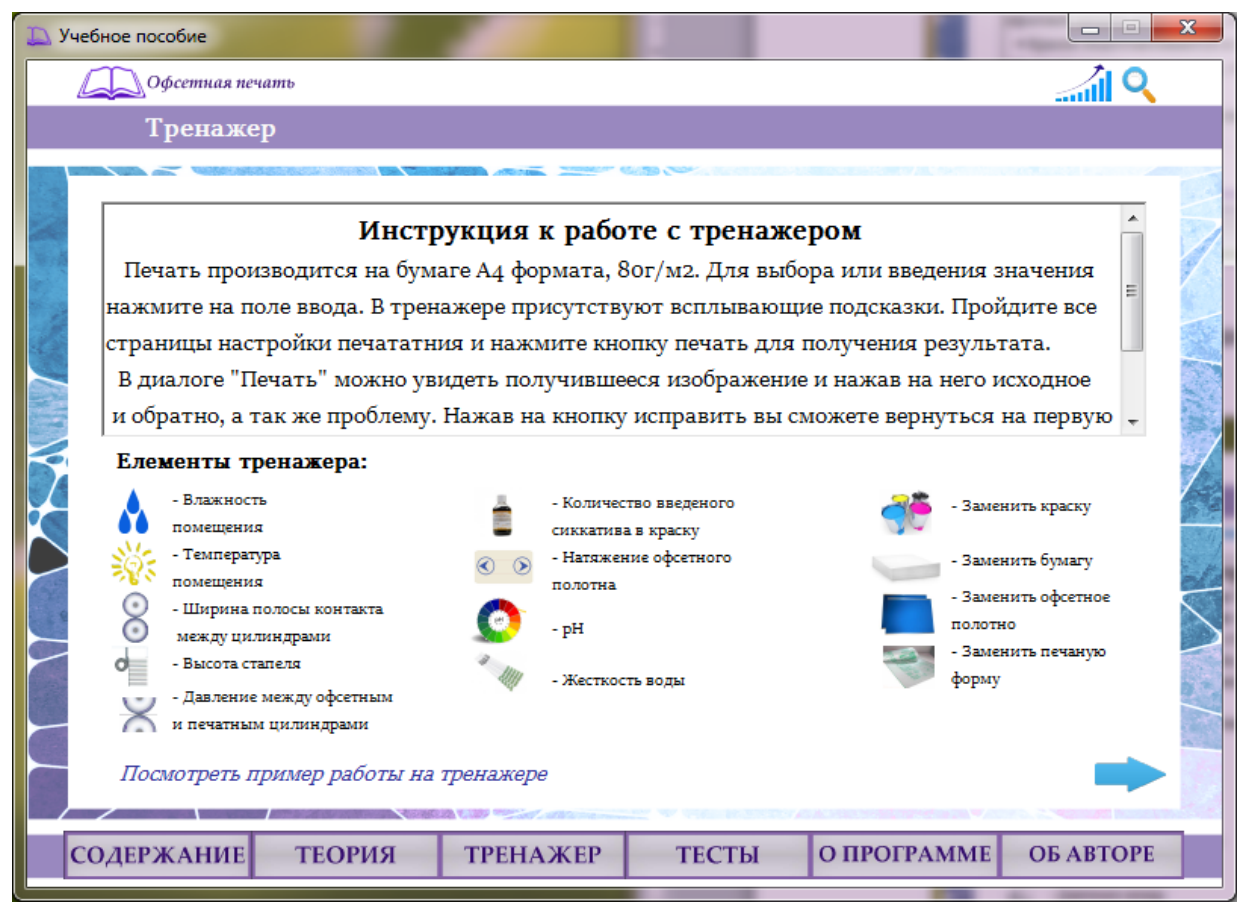

Малюнок 1. Сторінка «Інструкція до роботи з тренажером»

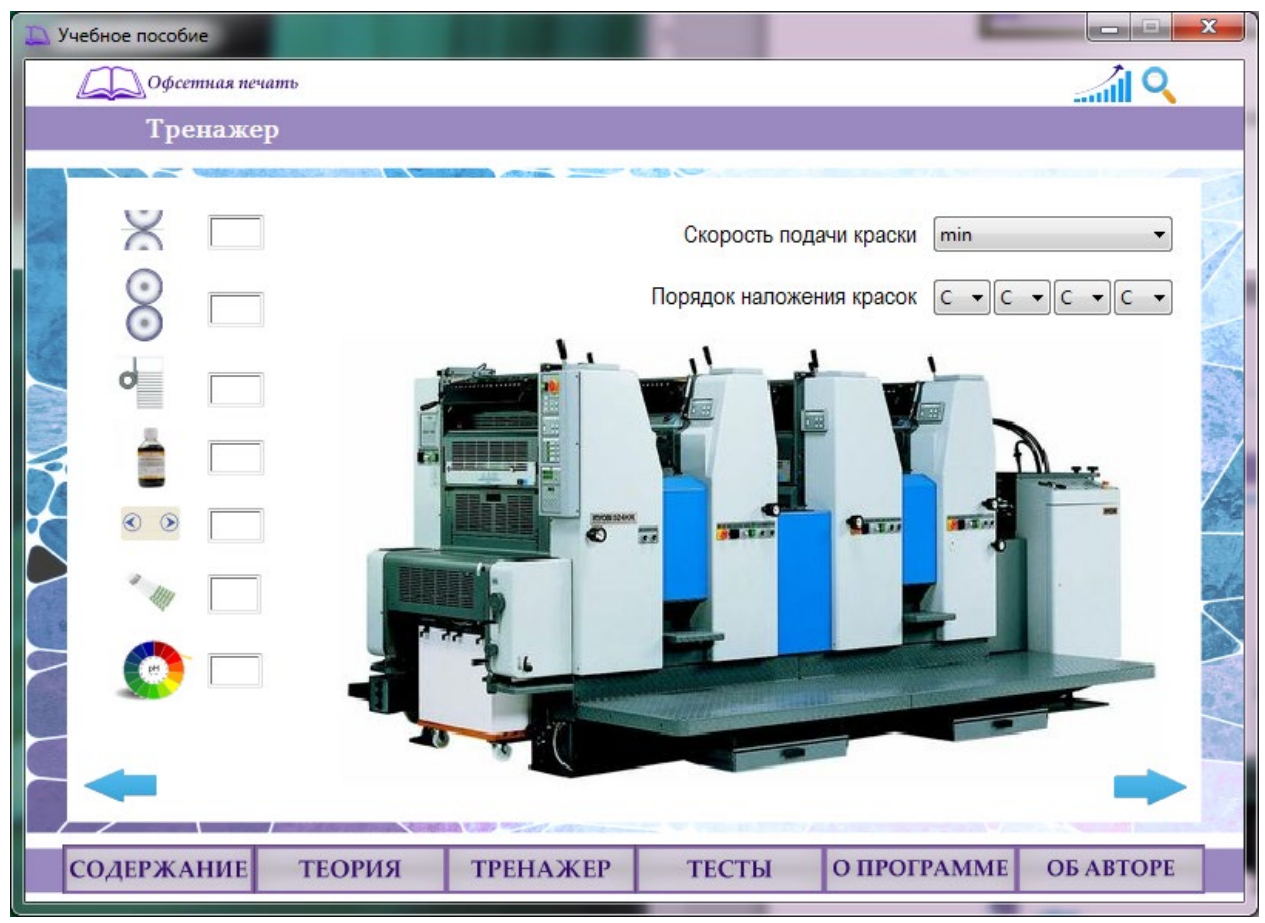

Малюнок 2. Сторінка «Тренажер»

Блок №5 формується викладачем в такому порядку: для кожного учасника навчально-виховного процесу створюється персональна тека 3 файлами; на підставі аналізу інформації, що знаходиться в блоці №3 викладач створює файли 3 оцінкою кожної зі спроб роботи з тренажером, групує файли по «спробам», 


\section{PEDAGOGY IN MODERN CONDITIONS}

оцінює отримані результати i, складає рекомендації щодо повторного вивчення того чи іншого матеріалу, а також формує підсумкову оцінку знань і умінь на момент тестування.

Основними напрямками вдосконалення програм-тренажерів слід вважати участь студентів у розробці програмно-тренажерних комплексів, які дозволяють отримати базові - інструктивні теоретико-практичні знання i навички, поповнювати їх «екстремальними» знаннями, розвивати не тільки аналітичне мислення, а й здатність до прогнозування можливих ситуацій під час друкування продукції на аркушевих офсетних машинах. 


\section{9 Упровадження воркшопових технологій у навчальний процес закладів вищої освіти}

Сучасна освітня система України динамічно розвивається, що спричинено геополітичними, соціально-економічними, інформаційними чинниками. Рух нашої держави до європейського простору актуалізує підвищення якісного показника освіти у ВНЗ. У зв’язку з цим національний освітній процес спрямований на пошук нових ідей, концепцій, технологій, які б не лише відповідали міжнародним стандартам, а також модернізували б українську освіту в бік підвищення іiі якості, рівного доступу до неї упродовж життя. Одним із пріоритетів національної політики є розбудова інформаційного суспільства через систему освіти, зокрема шляхом упровадження новітніх інформаційнокомунікаційних технологій (IКT) у навчальний процес. Це передбачає i розроблена «Стратегія розвитку інформаційного суспільства в Україні» від 15 травня 2013 року, реалізація якої припадає якраз на 2020 рік.

Сьогодні перед педагогами вищої школи поставлено завдання не лише навчати, а також виховувати людину інноваційного типу конкурентоспроможну, здатну успішно працювати в команді, володіти лідерськими здібностями, бути творчою й уміти застосувати здобуті знання на практиці. Як зазначає Н. Грицишина, «сучасний випускник повинен володіти рядом компетенцій, а не просто набором знань, умінь і навичок, які не завжди можливо сформувати у межах звичних форм навчання» [197].

Нові підходи і вимоги до професійного становлення тих, хто навчається, зумовлюють істотні зміни в методиці організації навчального процесу, змісті й інструментах підготовки до практичної діяльності. Вектор діяльності викладача у закладах вищої освіти все більшою мірою зміщується в бік застосування на лекціях і практичних заняттях ІКТ, інноваційних форм роботи зі студентами як в аудиторний, так і в позааудиторний час. Із цього приводу I. Коновальчук зауважує: «Значна роль в організації інноваційних освітніх процесів відводиться IKT, які виступають дієвими засобами збору, обробки, зберігання, передавання та використання інформації, необхідної для забезпечення науково-методичного, 
PEDAGOGY IN MODERN CONDITIONS

інформаційно-управлінського й консультативного супроводу нововведень у загальноосвітніх навчальних закладах» [198].

Нестандартні, цікаві, активні форми проведення навчальних занять із залученням IКT допомагають студентам розвивати комунікативну компетентність, навчають успішно вирішувати поставлені завдання й долати проблеми, доводити й аргументувати власну думку, проявляти організаторські здібності, ухвалювати стратегічні рішення тощо. Н. Кошечко з цього приводу стверджує: «Зрозумілим є посилений інтерес сучасних науковців до актуальних питань щодо розробки інноваційних освітніх технологій впливу на особистість та способів їх ефективного й оптимального використання у навчальновиховному процесі вищої школи. У ньому особливий акцент поставлено не тільки на сутності освітньої технології, її змісті, а й на можливості якісного передання інформації, досвіду викладачем, тобто на володінні ним інноваційними технологіями навчання та викладання навчального матеріалу» [199].

Цілком слушно зауважує С. Литвиненко, що «в сучасних умовах бурхливих змін та швидкого старіння інформації традиційна навчальна модель набуває істотних обмежень, що зумовлює пошуки форм, методів і технологій навчання, які сприяють формуванню й розвитку особистості людини, іiі самостійності, готовності до співробітництва, творчості та здатності приймати рішення» [200]. Справді, сучасний викладач, окрім грунтовного знання свого предмету, повинен уміти науково доступно, кваліфіковано та креативно донести освітній матеріал до студентства, володіючи новітніми освітніми технологіями.

Освітню технологію услід за дослідниками розглядаємо як сукупність засобів, форм і методів навчання, спрямованих на формування необхідних знань, умінь, навичок, представлених за відповідною спеціальністю [201, 202]. Під інноваційними технологіями розуміємо системний набір засобів та прийомів організації начального процесу, застосованих упродовж усієї навчальної діяльності - від постановки мети та завдань до отримання якісних результатів. Якраз освітні інноваційні технології викладання у ЗВО є ефективними 
PEDAGOGY IN MODERN CONDITIONS

інструментами праці викладача, адже вони забезпечують цілеспрямований характер навчання; стимулюють суб’єктів навчальної діяльності до активності; дозволяють швидко засвоїти великі обсяги матеріалу та перетворити навчання у творчу діяльність. Використання інноваційних технологій при підготовці студентів у закладах вищої освіти дозволяє створити комфортні умови для навчальної діяльності, за яких той, хто здобуває знання, відчуває себе комунікативно відкритим, успішним, інтелектуально спроможним.

Орієнтуючись на європейську практику, українські 3 ВО активно впроваджують інноваційні освітні технології, популярними серед яких є такі форми навчання: distance learning, електронне навчання (e-learning), мобільне навчання (m-learning), змішане навчання (blended learning), навчання із залученням інтерактивних методик, навчання за технологією тренінгу та ін. Як зауважує О. Коротун, «це відбувається у зв’ язку з наявністю високошвидкісного Інтернету, високим рівнем комп’ютерної грамотності суб'єктів навчання та технічним (комп’ютерним) оснащенням вищих навчальних закладів» [203].

Із метою підвищення ефективності підготовки фахівців вищої школи, а також для перетворення навчальної діяльності в активну взаємодію, викладачі на лекційних і практичних заняттях усе частіше використовують навчання із залученням інтерактивних методик та IKT: ділові ігри, тренінги, майстер-класи в режимі онлайн, відеолекції, навчальні майстерні, навчальні форуми, доповнюючи їх технічним (комп’ютерним) супроводом. Такі технології надзвичайно популярні, вони практиковані у вищій школі вже не один рік, адже «забезпечують масштабний обмін досвідом між практикою і теорією, дають можливість навчання на реальних прикладах, можливість проявити отримані знання та зарекомендувати себе як фахівця у майбутньому» [204]. Окрім того, використання IКТ засвідчує переваги над традиційними методичними системами навчання в контексті реалізації особистісно-орієнтованого підходу, оскільки більшою мірою сприяють реалізації принципів індивідуалізації й диференціації навчального процесу, розширенню його змісту, підвищенню інтенсифікації і результативності навчання в цілому [205]. 
PEDAGOGY IN MODERN CONDITIONS

Малоапробованою, проте дуже перспективною в навчальному процесі ВН3 є така інноваційна технологія, як воркшоп (з англ. workshop - майстерня). Під воркшопом розуміємо інноваційну технологію, що характеризується інтенсивністю, активністю обох суб'єктів навчальної діяльності, спрямовану на практичну реалізацію отриманих знань, умінь та навичок. Основоположник теорії воркшопу як складової динамічного навчання К. Фопель визначає це поняття так: «Форма інтенсивного навчального заходу учасники якого навчаються, перш за все, завдяки власній активній роботі у групах» [206].

Якщо на сьогодні технологія воркшопу набула популярності у бізнесовій, журналістській, управлінській, культурно-мистецькій сферах, то в освітній галузі ця технологія ще мало апробована й досліджена, хоча вона має великий методичний потенціал. Адже заняття із використанням форкшопу з технічним (комп'ютерним) супроводом носить особистісний характер, сприяє розвитку колективної роботи, націлює на вирішення проблемних питань, має велику практичну цінність. Крім того, воркшоп, за свідченням О. Кудирко, сприяє досягненню синергетичного ефекту на заняттях завдяки максимальному внеску кожного з учасників у робочий час [204].

Зважаючи на це, дослідження методологічних засад застосування технології воркшопу в навчальній діяльності викладача ВНЗ $є$ продуктивним й актуальним. У зв'язку з інноваційністю та інтерактивністю занять у форматі воркшопу, його доцільно розглядати як приклад упровадження ІКТ в навчальній діяльності вищої школи.

Вітчизняні й зарубіжні науковці активно досліджують використання в навчальному процесі комп’ютерних, комунікаційних, інформаційних, мультимедійних технологій, а також технології інтерактивних методів навчання. Дослідники переконані, що «упровадження інноваційних технологій у навчальний процес створило сприятливі умови для вдосконалення різних форм $\mathrm{i}$ методів викладання» [207].

Специфіку використання інноваційних технологій у закладах вищої освіти грунтовно дослідили й проалізували І. Дичківська [208]; О. Дубасенюк [209]; 
PEDAGOGY IN MODERN CONDITIONS

M. Козяр [209]; I. Коновальчук [198]; Н. Кошечко [199]; I. Намакштанська Ю. Новикова, Р. Назар [207]; О. Пєхота А. Кіктенко, О. Любарська [202]; Л. Петренко [217]; О. Пометун; Г. Селевко; С. Сисоєва; В. Стрельніков, I. Брітченко [219] та інші.

Воркшоп у загальному значенні як захід, практичний семінар розглядали у своїх працях С. Петров [211]; О. Чікуров; І. Шаповалова тощо. Порівняно небагато студій, присвячених дослідженню воркшопових технологій в освіті. Найбільш грунтовною є праця німецького дослідника К. Фопеля «Еефективний воркшоп. Динамічне навчання», у якій автор узагальнив різні теоретичні напрацювання щодо технології воркшопу, комплексно описав особливості занять у форматі воркшопу, найбільш повно розкрив прикладні аспекти організації заходу такого типу. Автор розглядає воркшоп як навчальний процес, навчальний захід, навчальну групу, навчальний тренінг [206]. Інші науковці вивчали воркшоп за такими аспектами: як форма виховання етнічної свідомості (О. Абасалієва) [212]; як метод упровадження інтерактивних технологій у бібліотеці (О. Запорожець) [213] та інше.

Лише окремі наукові розвідки присвячені вивченню застосування технології воркшопу в навчальному процесі. Так, О. Кудирко зосередила увагу на дослідженні сутності й методичних особливостей застосування воркшопу на практичних заняттях студентів ЗВО [204]. У свою чергу Н. Грицишина проаналізувала технологію воркшопу як одну з нових форм і методів навчання студентів іноземної мови [197]. С. Литвиненко охарактеризувала особливості використання воркшопів у підготовці майбутніх психологів до професійної діяльності [200]; Н. Боринець закцентувала увагу на технології воркшопу в трудовому навчанні [214]. Усі науковці, які певною мірою досліджували таке навчальне явище, як воркшоп, сходяться на тому, що воркшоп - це особлива форма й технологія роботи з групою дорослих, у якій переважають інтерактивні форми роботи та провідна роль у здобутті знань і прийнятті рішень належить активності самих учасників навчальної групи [200]. 
Технологію воркшопу в освіті частково досліджували такі закордонні вчені, як N. Manouselis, H. Drachsler, K. Verbert and O. Santos; J. Yost, D. Ciliska and M. Dobbins, L. Uden, J. Sinclair, Y. Taо and D. Liberona та інші. Проте таких розвідок небагато і всі вони стосуються воркшопу як традиційної «навчальної майстерні». Незважаючи на впровадження упродовж останніх років у навчальний процес 3ВО інноваційних комунікаційних технологій, нових креативних форм роботи зі студентами, дистанційного й змішаного навчання, а також відповідно появи наукових розвідок, присвячених вивченню застосування викладачами інноваційних методик, усе ж дотепер відсутні комплексні дослідження щодо аналізу технології воркшопу в навчальній діяльності вищої школи.

На сучасному етапі важливими є студії, спрямовані на узагальнення практичного досвіду і переваг використання воркшопів як ІКТ на лекційних і практичних заняттях зі студентами. Доцільними, безумовно, є дослідження поетапної організації заняття-воркшопу, вивчення специфіки проведення воркшопів на прикладі конкретних спеціальностей чи навчальних дисциплін; визначення позитивних і негативних моментів застосування такої форми роботи зі студентами. Не менш важливо також описати роль викладача як ведучого, модератора чи керівника заходу у форматі воркшопу. У зв'язку з тим, що навчальний процес у вищій школі часто інформатизований, доповнений мультимедійними засобами, тому доцільним стало б вивчення можливостей упровадження в навчання студентів воркшопів у режимі онлайн. Усі ці перераховані вище моменти стали об'єктом нашого дослідження, чим i зумовлена актуальність представленої праці.

Мета наукового дослідження - систематизувати теоретичний та прикладний досвід організації заняття у форматі воркшопу та спроектувати його на навчальний процес вищої школи як приклад упровадження IКТ довести потенційні можливості воркшопу як активної інноваційної технології; акцентувати увагу на освітніх перевагах застосування воркшопів у навчальній діяльності із метою формування інформаційно-комунікаційних компетентностей у студентів; представити практичний досвід організації інтерактивних занять у 
форматі 1) інтегрованого воркшопу з технічним (мультимедійним) супроводом як приклад змішаного навчання (blended learning); 2) воркшопу в режимі онлайн iз використанням безкоштовної навчальної платформи «Prometheus» як приклад дистанційного навчання.

Матеріалом для пропонованої розвідки стали теоретичні напрацювання щодо застосування воркшопових технологій в освіті, а також практичний досвід організації й проведення навчальних занять у форматі традиційного воркшопу викладачами кафедри соціальних комунікацій Волинського національного університету імені Лесі Українки.

У проведеному дослідженні використано як загальнонаукові методи (аналіз, синтез, порівняння, узагальнення), так і вузькоспеціалізовані. Загальнонаукову методологію застосовано під час теоретичного огляду української і зарубіжної наукової бази, пов’язаної з темою дослідження. Здійснено також вивчення й узагальнення педагогічного досвіду підвищення якості процесу навчання студентів у вищій школі через застосування сучасних інноваційних технологій. Методами спостереження й педагогічного експерименту послуговувалися при використанні технології воркшопу на практичних заняттях у навчанні майбутніх фахівців із журналістики і видавничої справи. За допомогою методу анкетування студентів підтвердили результати успішного застосування технології воркшопу в навчанні.

У широкому значенні поняття воркщоп розглядають як навчальний курс, технологію, форму, маркетингову презентацію тощо. Заходи у форматі воркшопу сьогодні користуються великою популярністю, особливо у сфері рекламного бізнесу та маркетингу.

Досліджуючи воркшоп в освітній галузі, зокрема як складову організації навчального процесу, доцільно, 3 нашого погляду, використовувати термін активна інноваціийна технологія.

Основоположник теорії ефективного воркшопу К. Фопель розглядає це явище різнобічно: як 1) динамічний навчальний захід, на якому учасники навчаються завдяки власній активності; 2) навчальний проияес, у якому кожен 
PEDAGOGY IN MODERN CONDITIONS

бере активну участь, та під час якого учасники багато дізнаються один від одного; цей процес зосереджений на переживаннях і враженнях учасників, а не компетентності ведучого; 3) навчальну груnу, яка допомагає всім учасникам стати після закінчення навчання більш компетентними, ніж до початку; 4) навчальний тренінг, результати якого залежать передовсім від внеску учасників і меншою мірою від знань ведучого [206].

Ця інноваційна технологія особливо актуальна в навчальному процесі вищої школи, адже абсолютно перебудовує традиційну схему організації лекційних і практичних занять. На жаль, сьогодні в українській освіті присутні такі негативні явища, як відсутність мотивації в отриманні знань, домінування теоретичного навчання над практичним, низька ефективність навчальної діяльності тощо. Зважаючи на це, вкрай необхідно забезпечити зворотний зв'язок зі студентами, підвищити їхню зацікавленість у навчанні. - я б його десь перемістила, а то якось нема плавного викладу матеріалу. Якраз цьому сприяє така активна інноваційна технологія, як воркшоп, адже організація практичних занять у форматі воркшопу 3 технічним (комп'ютерним) супроводом дозволяє максимально залучити студента в роботу, спонукати його до активної комунікації. С. Литвиненко стверджує: «Це своєрідна майстерня, на якій професіонал ділиться своїми думками та здобутим досвідом, але також ініціює дискусії та обмін думками за допомогою залучення учасників до обговорення пропонованої проблематики» [200]. На інноваційність цього різновиду навчальної діяльності вказує Н. Грицишина: «Це нетрадиційний урок, оснований на багатоплановій дидактичній i психологічній діяльності, спрямованій на вирішення визначеної проблеми i організованій відповідним способом [197].

Зважаючи на те, що воркшоп - це робоча майстерня, то ця технологія передбачає активність і самостійність усіх його учасників. Якщо ж заняттяворкшоп має ще технічний (комп'ютерний) супровід, який може реалізуватися через застосування різноманітних мультимедійних засобів, прямих ефірів, онлайн-майстер-класів, відеолекцій тощо, то практичний ефект ще більший. Це 
сприяє також розвитку інформаційно-комунікаційних компетентностей у тих, хто навчається.

Проведення заняття-воркшопу із застосуванням технічних (комп'ютерних засобів) як прикладу упровадження IКТ у навчальному процесі вищої школи на противагу традиційному навчанню має такі важливі переваги:

- основний акцент зроблено на практичному аспекті;

- постійний обмін інформації між учасниками;

- отримання динамічного знання;

- формулювання самими студентами мети та завдань заняття, а також основних положень, які повинні бути розглянуті та вивчені (Кудирко);

- викладач $\epsilon$ координатором, посередником i модератором навчального процесу, а не керівником;

- студенти самі генерують знання, доносять їх до інших учасників групи, а не лише викладач, як це прийнято традиційно;

- активна колективна цілеспрямована діяльність, де кожен учасник робить максимальний внесок у заняття, чим підвищує свою компетентність;

- основна увага приділена вирішенню проблемних та актуальних питань.

Проведення заняття у форматі форкшопу додає студентам більшої активності, відкритості, адже вони знаходяться на рівних правах із модератором воркшопу - викладачем чи іншим запрошеним фахівцем у певній галузі. Саме активності навчальної групи належить першорядна роль в отриманні знань та прийнятті рішень. Викладач під час воркшопу виступає фасилітатором, адже він не лише надає знання, але також виступає посередником між учасниками, активізує групу у процесі вирішення проблемних моментів й пошуку правильних рішень.

Воркшоп може мати форму відеолекції, практикуму онлайн, круглого столу, тренінгу тощо із використанням мультимедійного супроводу. Усе залежить від креативності й фаховості викладача, від того, наскільки він методично грамотно побудує навчальний процес. Незважаючи на те, що найпоширенішими воркшопи виявилися серед представників творчих професій (дизайнерів, художників, 
PEDAGOGY IN MODERN CONDITIONS

журналістів) [200], проте, коли говорити про освітню сферу, то вони дуже продуктивні у навчальній діяльності при опануванні будь-якої спеціальності. Адже в процесі викладання природничих, технічних, математичних, соціогуманітарних дисциплін можна успішно використовувати воркшоп як активну технологію.

Свідченням упровадження IKT в освітній процес при організації й проведення занять аналізованого формату є ігровий навчальний воркшоп. Ця інтеракативна технологія актуальна тим, що дозволяє створити комфортний клімат навчання та невимушену атмосферу навколо всіх суб'єктів навчальної діяльності. За таких умов у студентів формується креативне мислення, вони знаходять нові й цікаві підходи в розв’язанні запропонованих завдань, швидко вирішують поставлені проблеми, успішно засвоють навіть складні розумові моделі.

Сам собою воркшоп не буде настільки презентабельним, якщо під час його організації не використовувати різноманітні інтерактивні методи навчання, які важливо вміло поєднувати, а також комп'ютерний (технічний) супровід мультимедійні засоби. Серед методів, застосованих від час воркшопу, дослідники вказують на такі: мозковий штурм, лекція-діалог (інтерактивна лекція), робота в парах, робота в малих групах, дискусії (диспути, діалоги), презентація, демонстрація, моделювання ситуацій, навчання дією (тренінг навичок), ігри (ділові, рольові), відеотренінг, кейс-метод, фокус-група, акваріум, вистава, екскурсія [213].

Технологія воркшопу на відміну від інших традиційних методів має такі переваги: по-перше, це активна комунікативна діяльність студентів, зреалізована переважно у формі діалогу; по-друге, учасники воркшопу можуть працювати в команді, де модератором виступає як знайомий їм викладач, так і незнайома людина - запрошений відомий гість, фахівець-практик у певній справі тощо. Потретє, ця технологія передбачає різні види навчальної праці, які дають можливість формувати і розвивати складні компетентності й навички. Унаслідок того, що воркшоп - ігрова інноваційна методика роботи, направлена на 
PEDAGOGY IN MODERN CONDITIONS

реорганізацію свідомості на противагу стандартним, нормативним моделям, які, як правило, задають усю динаміку мисленнєвого процесу, цей вид роботи розкриває великі можливості для формування різноманітних компетенцій у студентів [197]. На відміну від інших методів і технологій, воркшоп воркшоп вирізняється тим, що має виразну тематичну спрямованість, а спільно організований колективний навчальний процес дозволяє поглянувати на поставлені невирішені завдання об'ємно, з різних найнесподіваніших ракурсів. Переважно завжди результатом успішного воркшопу виступає якийсь здійснений проект чи ухвалені важливі рішення. Як зазначають дослідники, «після закінчення воркшопу у групи є певний інструментарій, модель поведінки в конкретній ситуації» [212].

Ця навчальна технологія має великий потенціал із погляду фізіологічнопсихологічних особливостей тих, хто бере в ньому участь, адже, як відомо, за фізіологічно-мисленнєвими показниками людина засвоює лише 10 \% прочитаної інформації, 20 \% сприймає на слух, 30-40 \% запам'ятовує під час візуалізації інформації, $60 \%$ - в ході усного обговорення, $80 \%$ - під час самостійного пошуку і формулювання проблеми, 90 \% - під час самостійного формулювання і вирішення проблеми. Якраз технологія воркшопу найбільш повно релізує дві останні особливості, оскільки робота в навчальній груповій майстерні із чітко окресленою тематичною спрямованістю передбачає самостійне формулювання $\mathrm{i}$ спільне вирішення поставлених проблемних завдань.

Унікальність воркшопової технології вбачаємо в тому, що з одного боку вона передбачає самостійне навчання кожного з учасників; з іншого - групове, колективне навчання, адже воркшоп передбачає динамічну роботу певного мікроколективу учасників. Ця технологія актуальна тим, що зумовлює створення уявної навчальної майстерні, у якій активно працюють усі учасники групи студенти, що опановують певну навчальну дисципліну. Воркшоп дозволяє під час активної комунікативної взаємодії втілювати теоретичні знання на практиці, збудувати таку модель навчання, у якій передовсім переважає дія, що й відрізняє цю технологію від інших. Одержання актуального досвіду, здобутого у груповій 
роботі, - основна складова успішного навчального воркшопу. Вдала організація воркшопу вимагає від викладача великих зусиль, адже, як слушно зауважує С. Литвиненко: «...добре організований воркшоп передбачає сукупність різних методів, що активізують учасників та включають у процес групових дискусій та рефлексії, самостійного здобуття знань» [200]. Як зазначають дослідники, воркшоп можна проводити як самостійний захід, а також як розділ більш масштабного заходу (семінару, конференції). Воркшоп поєднує риси семінару, тренінгу, групувого консультування, «ярмарку ідей» тощо [213].

Аби воркшоп справді перетворився на високопродуктивну навчальну майстерню, повинна бути досягнута велика інтенсивність роботи в групі, а самостійність та активність кожного з учасників мусять бути максимальними. Велика роль відведена й керівнику (ведучому) - експерту воркшопу, адже він скеровує навчальну діяльність учасників у потрібне русло, підбирає методи і прийоми для отримання високих результатів, успішно контролює увесь навчальний процес. Викладач (запрошений фахівець) повинен дотримуватися таких основних складових для ефективного проведення воркшопу: модератор повинен обрати ті навчальні техніки, які відповідають ситуації і групі слухачів; під час заняття необхідно підтримувати клімат «прийняття»; у навчальній групі повинна панувати «довірливість».

Перед викладачем - ведучим воркшопу (в іншому випадку - запрошеним фахівцем) поставлено непросте завдання організатора: він повинен мати високі кваліфікаційні навички тренера й консультанта, володіти на найвищому рівні інформаційно-комунікаційними компетентностями, бути хорошим актором, адже неодноразово потрібно швидко перемикатися з однієї ролі на іншу. Він також мусить добре орієнтуватися у запропонованій технології проведення лекційного чи практичного заняття, знати всі особливості студентського колективу, із яким працює; бути впевненим в інструметарію, який використовує, а також послідовно виконувати всі поставлені завдання. Адже в кінцевому результаті після проведення заняття-воркшопу повинна бути досягнена така його 
основна мета: кожен студент - учасник воркшопу - повинен відкрити для себе більше, ніж знав й умів до цього, навчитися того, чого не очікував.

Крім того, воркшоп потрібно організувати так, аби кожен етап навчання був цікавим і значеннєвим, давав можливість управляти навчальним процесом. У групі серед учасників повинна бути позитивна атмосфера підтримки, взаємоповаги і визнання, аби кожен мав можливість до відкритої комунікації. Для того, аби воркшоп став продуктивним, потрібно навчальний процес організувати так, аби навички формувалися поступово. Зважаючи на фізіологічно-психологічні особливості кожного студента - учасника групи, педагог повинен задіювати у ході воркшопу візуальні, емоційні, тактильні, аудіальні, вербальні та невербальні здібності кожного. Добре, коли під час воркшопу присутнє активне оцінювання слухачів, яке більше мотивує, дає можливість прийняти на себе відповідальність за власне навчання, продовжує розвивати здібності.

Дослідники технології воркшопу зауважуть: «Їх найважливіша характеристика - різноманіття. Будь-який добре організований воркшоп передбачає сукупність різних методів, які активізують учасників, роблячи їх не просто слухачами. На воркшопі вчаться за допомогою отримання актуального досвіду і особистого переживання, що набагато легше досягається в груповому, ніж в індивідуальному навчанні» [212].

Викладачі кафедри соціальних комунікацій Волинського національного університету імені Лесі Українки мають практичний досвід застосування воркшопових технологій в організації навчального процесу майбутніх фахівців iз журналістики та видавничої справи. На заняттях зі студентами було апробовано технологію змішаного навчання (blended learning) під час проведення пар у форматі інтегрованого воркшопу 3 технічним (мультимедійним) супроводом. Зокрема, на двох заняттях із дисципліни «Редакторська майстерність» студенти 3 курсу спеціальності «Журналістика» стали учасниками міні-воркшопу тривалістю три години. Короткотривалий інтенсивний інтегрований воркшоп під назвою «Редакторсько-видавнича 
PEDAGOGY IN MODERN CONDITIONS

підготовка довідників-порадників для першокурсників» складався 3 таких навчальних етапів:

1) організація викладачем (модератором воркшопу) активної групи студентів-третьокурсників й оголошення теми воркшопу;

2) формулювання студентами мети, завдань і визначення методів організації роботи в уявно створюваній навчальній майстерні;

3) перегляд онлайн майстер-класу щодо підготовки брошур ручного способу виготовлення;

4) перегляд відеопрезентації у форматі інтерв'ю зі студентами першого курсу;

5) формулювання й представлення студентами концепції й контенту проекту майбутнього видавничого продукту;

6) обговорення й вибір актуальної концепції для подальшої роботи над довідником-порадником брошурного типу;

7) власне робота над створенням довідника-порадника для першокурсників із застосуванням підручних засобів;

8) підведення результатів - одержання готового редакторсько-видавничого продукту.

Менш тривалий воркшоп (1,2 год.) на тему «Правила оформлення бібліографії» був організований під час проведення заняття «Практикум із фаху». Для досягнення динамічного ефекту й максимального практичного характеру для участі у занятті, окрім викладача-модератора, були залучені фахівці університетської бібліотеки - працівники бібліографічного відділу. Попередньо отримавши короткі теоретичні відомості про довідковобібліографічний апарат видання безпосередньо від фахівців, студенти на практиці втілювали свої бібліографічні навички, працюючи 3 віртуальною довідкою, електронним каталогом бібліотеки. У результаті проведеного воркшопу студенти поглибили свої знання про бібліографічний опис документів, а також навчилися правильно укладати списки літератури до наукових праць, бібліографічних покажчиків тощо. Під час організації такого заняття-воркшопу 
був залучений технічний (мультимедійний) супровід, адже учасники воркшопу безпосередньо в режимі онлайн могли віртуально мандрувати електронним сайтом бібліотеки, користуватися електронним каталогом, отримувати необхідну інформацію з віртуальної довідки. Фахівці - модератори воркшопу під час навчання також використовували мультимедійні презентації, додаткові електронні матеріали тощо.

У форматі інтегрованого воркшопу проходив також віртуальний медіаміст між студентами нашого факультету та студентами, які навчаються за спеціальністю «Журналістика», із університету Литви. Короткотривале навчання й обмін інформацією між українськими й литовськими студентами відбувалися в режимі онлайн за допомогою skape-конференції. У ході цього заходу було досягнуто таких навчальних цілей: 1) студенти обох країн під час активного наукового спілкування отримали нові знання, що стосуються їхнього фаху; 2) зосередили увагу на шляхах вирішення поставлених актуальних та проблемних питань; 3) зреалізували практичний аспект, адже в ході воркшопу були продемонстровані конкретні наочні приклади, проблемні моменти українських та литовських медіа. Загалом увесь навчальний захід вирізнявся активною колективною діяльністю, адже кожен з учасників зробив великий внесок, аби досягнути поставленої мети воркшопу.

Неодноразово в університеті проходять короткотривалі воркшопи і за участі журналістів-практиків, редакторів всеукраїнських і регіональних медіа, піарменеджерів. На одному із таких воркшопів студенти, що здобувають фах журналіста, навчалися під керівництвом головного редактора ділового інтернетвидання «Конкурент» Андрія Лучика. Цей воркшоп мав відкритий характер, адже об’єднав студентів різних курсів. Застосування такої технології в навчальному процесі показало ії позитивний результат, адже студенти вперше працювали в командах у такому складі, брали участь у дискусії з креативною назвою «Чим газета відрізняється від прального порошку», майстерно виконували запропоновані завдання. Більшою комунікативною активністю вирізнялися ті студенти, які вже мають досвід роботи у журналістиці. Інші, 


\section{PEDAGOGY IN MODERN CONDITIONS}

переймаючи їхні знання і маючи значний теоретичний досвід із журналістських дисциплін, також висловлювали цікаві думки й пропонували нестандартні рішення. Воркшоп поєднував теоретичну й практичну складову, вирізнявся великою наочністю продемонтрованих прикладів із друкованих волинських 3МI, а також інтернет-видань, електронних сайтів. $\mathrm{y}$ створеній навчальній журналістській майстерні модератор запропонував учасникам заходу придумати власне видання. Як і характерно для воркшопу, у підсумку кожна із чотирьох команд представила концепцію власного регіонального ЗМІ та довела його професійну придатність.

Дослідження засвідчують, що в навчальному процесі вищої школи доцільно використовувати міні-воркшопи, тривалість яких обмежена 1 год-1, 5 год, оскільки застосування більш тривалих воркошів (існують такі, що проходять від половини дня до тижня) не дуже підходять для моделі навчання у вищій школі, що передбачає чергування лекційних і практичних занять. Окрім того, велика інтенсивність воркшопу швидко втомить студентів, адже ця технологія вимагає активної участі кожного й особливої віддачі, тому довготривало студенти в такому темпі працюватимуть неефективно. Якраз міні-воркшоп, що охоплює одне навчальне заняття (1,2 год), цілком виправданий для організації роботи зі студентами.

На нашу думку, серед актуальних методів, використаних на занятті iз залученням воркшопових технологій, можна використати такі:

1. Мозковий штурм. Цей метод ефективний, оскільки служить для генерації ідей, залучає до обговорення всіх присутніх учасників, стимулює групову синергію, дозволяє створювати безліч варіантів, перешкоджає необгрунтованій передчасній оцінці ідей. Це одночасно передбачає внесення ідей усіма членами групи, які модератор-викладач фіксує. Мозковий штурм актуальний тим, що втягує в процес обговорення всіх, збільшує можливості вибору варіантів.

2. Дискусія. Цей метод необхідний, оскільки зумовлює одержання агрументованих думок на певну навчальну проблему, заохоченні до критичного мислення, що виправдовує мету викладання, поліпшенні навичок спілкування, 
потрібно сформувати чи змінити ставлення до проблеми 3 боку слухачів. Учасники так званої «навчальної майстерні» повинні послідовно дотримуватися правил ведення дискусії: критикувати думки, а не особистість; пропонувати на противагу критиці альтернативи; дотримуватися встановленого регламенту; аргументувати власні висловлення; уважно слухати кожного та ін. Викладач повинен при цьому створити взаємну підтримку, атмосферу співробітництва, відзначати внесок кожного студента. При організації дискусійного воркшопу необхідно чітко окреслити мету навчання, обрати тему для обговорення, що чітко відображає мету, підібрати питання відкритого типу. Доцільно також підготувати додаткові питання, що будуть стимулювати уяву, якими ви зможете скористатися для досягнення цілей навчання. У ході дискусії модератор-педагог мусить залишатися безстороннім, не виражати власних думок щодо тих чи тих запитань, але водночас при цьому намагатися активізувати дискусію нестандартними запитаннями. Він також повинен заохочувати взаємну підтримку серед слухачів, стежити за реакцією учасників дискусії, що свідчитиме про ступінь розуміння обговорюваної проблеми. Підбивати підсумки потрібно як у ході дискусії, так і після ㄲï завершення, визначати вирішені завдання і ті, що потребують ще додаткового опрацювання.

3. Рольова гра. Цей метод ефективний тим, що стимулює учасників завдяки розважальній функції, активно привертає увагу групи, імітує реальний світ. Студенти під час такого навчального методу систупають у ролі акторів, а модератор при цьому спостерігає за рольовою грою. Рольову гру використовують зазвичай, щоб допомогти змінити ставлення учасників до навчання; дозволити їм побачити наслідки своїх дій щодо інших; дати можливість спостерігати, як інші люди можуть почуватися/поводитися у визначеній ситуації; створити безпечне оточення, в якому учасники можуть розглядати такі проблеми, які в реальному житті їм може бути незручно обговорювати; дозволити слухачам розглянути альтернативні підходи в роботі із ситуаціями. Після проведення гри необхідно підсумувати, запитати слухачівучасників, чого вони навчилися i виділити основні моменти невирішених 
завдань. Доцільно також попросити студентів поділитися своєю реакцією i спостереженнями.

Великі освітні перспективи у навчальній діяльності студентів ЗВО може мати також дистанційний воркшоп. Це така ж сама активна робота студентів у режимі онлайн, але на відміну від традиційного воркшопу, вона характеризується не груповою активністю, а самостійністю навчання та індивідуалізованим підходом. Дистанційний воркшоп, на нашу думку, найбільш підходящий для організації самостійної роботи студентів, адже 1) дозволяє студентові навчатися вдома у зручний для нього час; 2) здобувати динамічні знання індивідуалізовано; 3) необмеженість тривалості навчання (на відміну від традиційного воркшопу). У результаті навчання за допомогою дистанційного воркшопу учасники отримують знання i навички 3 конкретного питання. Потивний бік такої навчальної технології в тому, що під час онлайн-воркшопу, подібно до вебінару, студенти отримують навчальну інформацію, а потім успішно закріплюють іï на практиці. Така форма роботи дозволяє відразу перевірити отримані знання на практиці. Так, у ході викладання предмету «Редакторська майстерність» під час організації самостійної роботи студентів 3 курсу спеціальності «Журналістика» ми апробували форму дистанційного воркшопу. Для цього було використано навчальні можливості безкоштовної онлайн-платформи «Рrometheus». Усі учасники навчальної групи, попередньо зареєструвавшись на онлайн-курс «Інтернет-медіа», упродовж декількох тижнів навчалися за допомогою відеолекцій. Від студентів така форма навчання вимагала динамічних знань й активної участі, адже після кожної теми потрібно було перевірити набуті знання за допомогою інтерактивних завдань і тестів. Окрім переваги самостійності такого навчання, колективна активність цього воркшопу була зреалізована через наявність форуму, де студенти мали можливість обговорювати питання, які їх цікавили, з іншими студентами чи викладачами. Після успішного проходження навчального онлайн-курсу учасники отримали сертифікати, які підтвердили виконання ними самостійної роботи. 


\section{PEDAGOGY IN MODERN CONDITIONS}

Із метою визначення переваг використання воркшопу як форми організації практичного заняття було проведене анкетування серед студентів напряму підготовки «Видавнича справа та редагування». Усього було опитано 18 студентів - членів навчальної групи, які брали участь у воркшопі на тему «Редакторсько-видавнича підготовка довідників-порадників для першокурсників». Щодо позитивних моментів застосування технології воркшопу студенти вказали на такі: 35 \% - реалізація здобутих знань на практиці; 25 \% - відкритість і можливість комунікації, самовираження; 20 \% - динамічний характер навчання; 12 \% - успішний результат (створення готового навчального продукту); 8 \% - велика плідна активність у групі (див. рис. ).

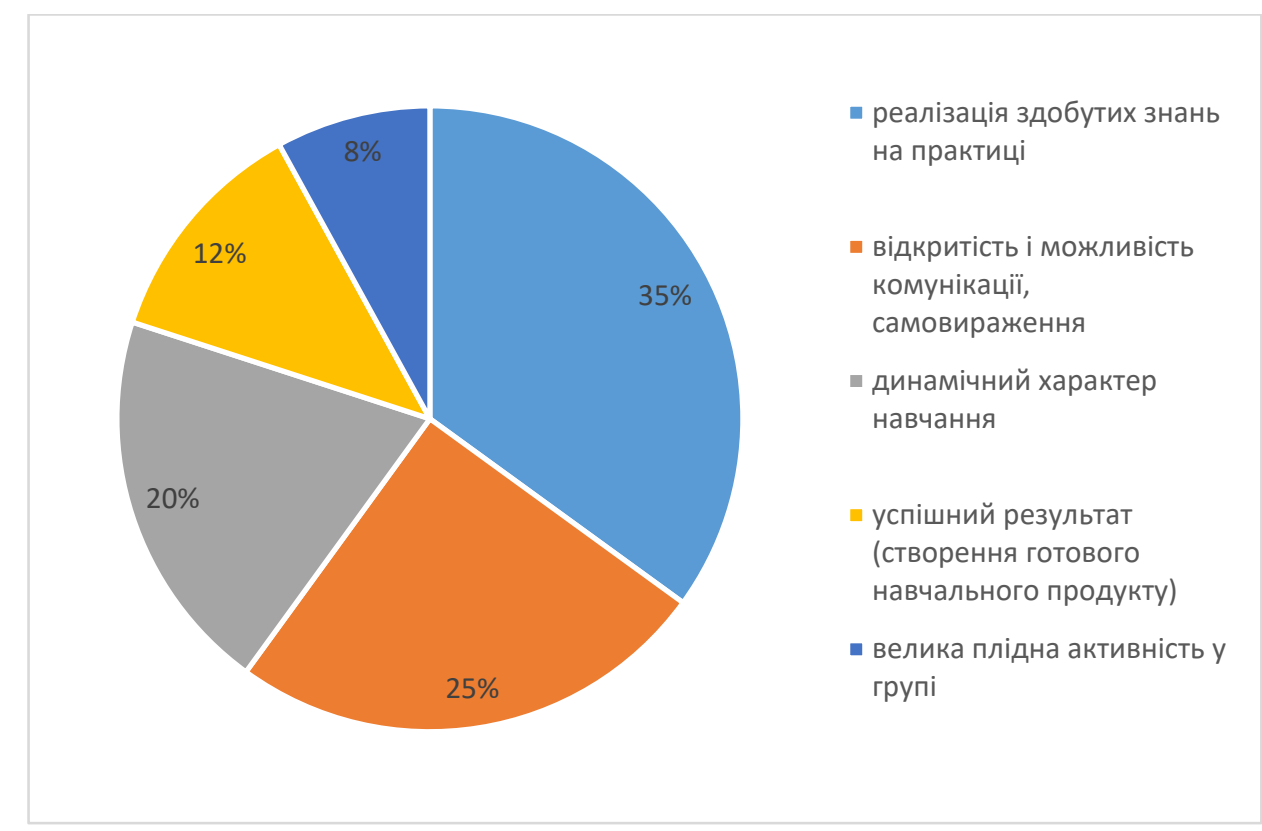

Рис. Результати анкетування студентів щодо їхнього ставлення до занять у форматі воркшопу

Отже, аналіз теоретичних напрацювань попередників і власний практичний досвід викладачів кафедри соціальних комунікацій щодо використання інтегрованих воркшопів із мультимедійним супроводом дозволяють говорити про широкі можливості навчального воркшопу як прикладу упровадження IКТ у педагогічному процесі. Інноваційною формою навчальної діяльності $\epsilon$ дистанційні воркшопи, різновидами яких можуть бути відеолекції, ойлайн- 
PEDAGOGY IN MODERN CONDITIONS

курси, віртуальні майстер-класи, які доступні на безкоштовних сервісах чи навчальних платформах (до прикладу, «Prometheus» тощо). Отже, можна підсумувати такі основні характеристики навчального воркшопу як інформаційно-комунікаційної технології:

1. Воркшоп - це активна інноваційна технологія, яка характеризується динамічним навчанням у колективі - навчальній групі, передбачає активну участь кожного студента - учасника заходу. Здобуття знань та навичок відбувається через власну та групову діяльність у взаємодії 3 висококваліфікованими експертами, якими можуть бути викладачі або запрошені професіонали-практики.

2. Під час воркшопу акцент зроблено на самостійному навчанні міні-групи, де немає слухачів чи спостерігачів, а всі активні діячі. Учасники навчальної майстерні самі визначають мету і ставлять завдання, які мають бути виконані у ході воркшопу, тобто вони самі несуть відповідальність за весь навчальний процес.

3. Для воркшопу характерно мінімум теоретичної i загальновідомої, максимум практичної і нової інформації. Головна мета заняття-воркшопу отримання індивідуального вирішення конкретних завдань кожного з учасників.

4. Викладач чи інший запрошений фахівець виступає на рівних правах зі студентами - учасниками заходу, його роль істотно менша, він тепер не керівник, а лише ведучий і модератор.

5. Результативність та ефективність воркшопу залежить як від динамічної колективної роботи, так і від індивідуального внеску кожного з його учасників. Темп роботи задається самою навчальною групою.

6. Одним із креативних різновидів навчальної майстерні $\epsilon$ воркшоп 3 інформаційним супроводом, який передбачає застосування мультимедійних засобів та різних технічних можливостей, а також онлайн-воркшоп, що має великий навчальний потенціал, адже дозволяє миттєво перевіряти на практиці отриману інформацію через інтернет. 


\section{PEDAGOGY IN MODERN CONDITIONS}

Перспективним у цьому напрямку дослідження можуть бути подальші студії щодо вивчення особливостей застосування воркшопових технологій у вищій школі, зокрема на прикладі викладання конкретних дисциплін. Цікавими були б спостереження щодо подальшого розвитку технології воркшопу 3 інформаційним супроводом у навчальній діяльності студентів. Доречно було б також проаналізувати використання воркшопів у навчальному процесі закордонних закладів вищої освіти. 


\section{SECTION 5. THEORY, PRACTICE AND TEACHING METHODS}

\subsection{Pedagogical aspects in student education}

The system of the educational process, which operated and continues to operate in any period of the educational process, provides for the acquisition of knowledge by students not for the sake of knowledge, but in order to carry out work on the education and development of the younger generation.

Each teacher solves this task during the teaching of his subject. The success of the work depends primarily on how fully he is able to reveal the scientific and ideological potential of students, whether he has a dialectical approach to solving a number of methodological problems.

To do this, the teacher needs to know the basic components of the learning process, understand their complex relationship and interaction, to master the methodological foundations of their work, based on philosophical positions, revealing the ways and forms of knowledge of truth. The task of the teacher is not only to communicate certain knowledge, but also to teach the student to acquire it independently. It is necessary to skillfully direct and adjust the activities of each student and student group as a whole, to create an environment in the classroom that would stimulate the development of students' abilities to creative approach, logical analysis, intelligence, teach them to work on themselves [221].

The purpose and objectives of this work are to analyze issues related to the specifics of the conduct and conduct of the educational process, accompanied not only by indepth theoretical training, but also related to pedagogical, methodological and psychological theory in the learning process. The scientific novelty of the goal of this work is the analysis of the studied issue, which consists in the application of new or existing optimized techniques and methodologies to achieve the objectives related to theoretical and practical problems of the current state of the topic.

The relevance of psychological and pedagogical patterns in the educational process is that during training and teaching classes lay not only the foundations of scientific knowledge, but also reveal fundamental issues related to students' perception of the 
information received, involved in the formation and improvement of necessary skills. The educational process involves fundamental training of students in all areas of knowledge of their future professional activities. To do this, the teacher must strive to build classes in such a way as to develop abstract thinking, individual creativity, the ability to independently set and solve individual problems. The system-forming factor of learning is the goals and content. There are various methods for determining the objectives of training, such as, for example: obtaining the desired dosage form in the future, long-term preservation of the properties of the obtained dosage form, etc. In the learning process you can solve certain problems using the principles of problem-based learning. Good pedagogical opportunities for the development of creative abilities are given by practical or seminar classes, in which the basic concepts are formed, qualitative tasks are practiced: for proof, for finding and analyzing errors, non-standard ways of solving problems are considered [221,222].

The following definition can be given that the goal is the expected future expected result of the joint activity of the teacher and the student. Under the generally accepted standard approach to the definition of goals, the following goal statements can be distinguished [223]:

1. Defining goals through the activities of the teacher and through the content of educational material. For example, to acquaint students with structural and logical schemes, with algorithms for solving problems from the course of drug technology and to show their application in practice in solving specific problems.

At such statement of the purpose the expected result of training does not fall out, thus the teacher supervises activity of students.

The result of training is a certain shift in the student's development, which is reflected in one or another of his activities. The shift can be both positive and zero or even negative. The main task facing the teacher as a link in the formation of knowledge, skills and abilities of students is to develop personality, support and creative search and organization of work based on the transition from routine forms of work to intellectual $[222,224]$. 
K.K. Babanskiy, L.V. Zankov, Sh.A. Amonashvili, V.F. Shatalov and other scientists-teachers consider the main sign of a good lesson to be the opportunity for children to live an interesting meaningful life in the lesson. The same is successfully projected for classes in higher education. Some authors in setting learning goals, taking into account the psychological and pedagogical patterns in the learning process, are guided by the word "should", that is, the student must be able to reproduce or the student must be able to demonstrate, etc. A necessary condition for understanding is students' awareness of the need to study the relevant material, the ability to use the studied material in specific conditions and new situations (this includes the application of concepts, production methods, knowledge of compatibility of drugs, rules, laws) [225].

The process of acquiring knowledge also goes through certain stages and has its own forms of knowledge. Analyzing the modern achievements of the theory of pedagogical science, methods of a new concept in educational activities, we can highlight aspects of assessing the level of educational achievements, taking into account the psychological characteristics of students to master the material presented. By managing cognitive activity, the teacher determines for them a logically sound way of learning, teaches them to mentally divide the cognizable subject into components through analysis and connect them together through synthesis. It is important to teach students to make generalizations, prove the correctness and refute the falsity of judgments and inferences, abstract and concretize, because it is on these mental operations is based on all educational activities of teachers and students to form and acquire skills. The purpose of assessing knowledge and skills at different stages of the learning process mainly falls on the so-called content-search stage, when the connection between concepts and phenomena, structuring the material, the transition from particular situations to general provisions and rules [223, 225].

The way goals are set, which is offered by pedagogical technology, is that learning goals are formed through learning outcomes expressed in the actions of students.

There are two stages in setting and implementing a goal.

1. Goal setting technology. 
2. Technology of achievement (realization) of the purposes.

The first stage is of paramount importance. If it is carried out formally, low-quality, then the second stage will be meaningless.

The system of assessment of educational achievements is of great importance in the whole educational process. Today, teachers, scientists in teaching methods are studying the quality of students 'acquisition of knowledge using certain methods, methods and results of students' knowledge development in accordance with modern requirements of the curriculum. The most difficult and important criterion for assessing students' knowledge is not only reliance on a specific question or solution of a particular problem, but the ability to determine the quality of learning. For example, in the educational process there is a system of systematic education and development of concepts in students, based on active cognitive and mental activity. That is, a system of concepts and terms is developed that help the student in his progressive movement to cognition $[222,223]$.

Another very important element of modern learning technology is the test as a tool for measuring the level of knowledge and complexity of tasks. Without such a tool, it is absolutely impossible to manage the learning process, especially in the technological version. As it not only helps to determine the level of knowledge, but also increases learning motivation and interest of students, and can also influence psychological aspects and participate in the formation of skills such as efficiency and systematization at the level of intelligence, erudition and intellectual abilities.

The formation of internal motivation for learning, a clear definition of the goals underlying the immediate development of students, is carried out taking into account individual abilities, the level of achievement of the student group as a whole. Methods of self- and mutual control, individual tasks stimulate the acquisition of skills for independent study of new material.

The results obtained. Modern achievements of teaching methods should include: the theory of development of concepts, principles of selection of facts, concepts, laws of science for the subject, the system of methods and techniques of teaching corresponding to its content, the relationship with other subjects. 


\section{PEDAGOGY IN MODERN CONDITIONS}

The general requirements for the transition from general to specific goals are quite simple - it is necessary to describe what the student can do as a result of learning, that is, the principles of achieving the goal. When specifying a goal, it is necessary to use verbs in its description that indicate an action with a certain result. The verbs used in the description of goals should be such that they indicate actions with a certain result, for example, the student reproduces any formulation, demonstrates skills and abilities to work with those other devices and apparatus [222, 225].

Conclusion. It can be concluded that there is no better method than that created by a teacher with a creative approach to his work and especially one that is skillfully guided by pedagogical, methodological and psychological theory, and a comprehensive and in-depth examination of knowledge is possible only with a combination of various forms, methods and techniques that the teacher must use in relation to the content of the tested material and the degree of readiness of the student. The most effective forms and methods of verification allow to involve all students in active cognitive activity from the first minutes of employment and to create necessary conditions for perception and assimilation of new material. In addition, since the training is aimed at expanding the professional horizons of students who are in the process of studying a subject, it is legitimate to ask and evaluate such questions that would test the student's progress. 


\subsection{New approaches to teaching English for special purposes}

The new approaches to teaching English and special subjects in English, presented by the British Council tutors at the seminars organized within the framework of the international project "English for Universities" is of interest.

As for the English for Universities project, “... it was initiated by the British Council Ukraine in December 2013 after the Ukrainian Ministry of Education had identified the improvement in levels of English in Ukraine's universities as a priority.

The project aims to make a commitment to helping Ukraine make a transformational change in the level of English among both university teaching staff and students at which they can fully participate on the international stage.

The project objective is to help Ukraine create its own sustainable EL teaching capacity to take students to B2 or C1 CEFR levels; introduce standards.

This will be carried out based on the recommendations of consultancies assessing what is needed to reach goals of fluency in English amongst more staff and students" [225].

It's very important because “... English is now recognized as a basic life skill for the 21 st century, like using a computer, rather than as a specialist accomplishment. It provides people with the ability to explore and navigate wider ranges of information and viewpoints than if they just have their home languages. The British Council's English for Universities Project has already started to make, and we believe will continue to make, a significant, sustainable and positive change to the way in which English is taught and learned in universities in Ukraine. This, in turn, will improve general levels of English amongst the adult population and will enhance Ukraine's prosperity, resilience and interconnectedness with the wider world" [226].

Being the active participants of the British Council activities, the "agents of change" (Garmash Sergii and Sadkovska Valeriia from the National Technical University "Kharkiv Polytechnic Institute", Ukraine) for two years successfully completed: the 35-hour ESP course on the British Council English for University project (Teacher Development Winter School, Kyiv, 08-13 February 2017) - (Garmash 
PEDAGOGY IN MODERN CONDITIONS

S. V., Sadkovska V. A.); the 42-hour ESP course on the British Council English for University project (Teacher Development Summer School, Kyiv, 13-19 July 2017) (Sadkovska V. A.); the 35-hour course Academic Teaching Excellence - English as the Medium of Instruction delivered by the British Council in Ukraine in the framework of the English for Universities project (Teacher Development Summer School, Kyiv, 15-19 July 2017) - (Garmash S. V.); the 35-hour ESP course on the British Council English for University project (Teacher Development Winter School, Lviv, 1-6 March 2018) - (Sadkovska V. A.); the 36-hour ESP course on the British Council English for University project (Teacher Development Summer School, Irpin, 1-6 July 2018) - (Garmash S. V.).

The following modules were introduced during the Teacher Development Schools at the particular courses:

CiVELT: Essentials, namely:

1. What is ESP?

2. Understanding needs.

3. Motivation.

4. Positive classroom interaction.

5. Developing authentic tasks.

6. Exploiting vocational contexts as resources.

7. Adapting the given course book.

8. Identifying and selecting lesson aims.

9. Identifying the components of a lesson.

10. Lesson planning - the roles of the teacher.

11. The basic elements of lesson planning.

CiVELT: Language of ESP, namely:

1. The Language of ESP: Grammar.

2. The Language of ESP: Lexis

3. The Language of ESP: Functions.

4. The Language of ESP: Writing and Written Language.

5. The Language of ESP: Reading and Listening. 
PEDAGOGY IN MODERN CONDITIONS

6. The Language of ESP: Speaking and Spoken Language.

CiVELT: ESP course and materials. ESP teacher CPD, namely:

1. ESP course design for specified groups of learners.

2. ESP materials selection and evaluation.

3. Categories of errors and error correction techniques.

4. Utilisation of learners' content.

5. Assessment and evaluation forms and practices.

6. Continuing professional development (CPD) range of tools and ways for an ESP teacher CPD [227].

"The course objectives are to familiarize participants with key principles of ESP approach and enable them to gain basic knowledge about ESP learning and teaching including understanding ESP learner's needs, motivation, ESP materials and task design, ESP lesson planning etc.

For effective training the key role is assigned to the teacher as an organizer and inspire of the training process. There is a variety in ESP lesson planning, even own learning styles of the trainers" [228].

"Review some problems arisen during training process in English. According to the definition ESP is defined to meet specific needs of the learners. In this case foreign students trained at the engineering departments. The most of them are from the Arabian countries, less - from Africa and Asia. The obvious objective of them is getting the diploma in some particular branch without any efforts. It isn't a secret that overwhelming majority of these students have quite poor as an entry educational level as a behavioral level. That's why they were not able to enter any higher educational institutions in their native countries or in developed countries where payment for training is quite expensive and requirements are too high. This situation caused a huge amount of problems. And one of them is how to motivate these students and how to involve them into the educational process" [229]. The main reason of the conflict in such situations is the difference in objectives.

"Evidently, there is the sufficient deference in the initial educational level because of different branches of training but there are a lot of coincidences. The majority of 
foreign students are from the 'problem' countries of Asia and Africa because of permanent war conflicts and poor standards of living there. The only thing which combines them is their willing to stay in the Western Europe after graduating in Ukraine (more than $75 \%$ ). If it's a legal way - the students ought to become the competitive specialists in the international market of labour. So they should be more motivated during their training in Ukraine" [230].

As for training Ukrainian students in English, “...there is another problem which is partly connected with the previous one - poor background. Double translation (from English into Russian or Ukrainian and then from Russian or Ukrainian into English) reduces efficiency of the training process - shortens the necessary materials and poor understanding it by the majority of the student trained in English. Such groups are formed only to "correspond" to the call of the times. It's not a secret that the majority of Ukrainian universities have a desire to be at the same level with the famous European universities. Numerous artificial rates only promote bureaucracy but not a creative atmosphere at Ukrainian universities. This situation is caused by the policy of nepotism as a kind of corruption" [311].

It should be stressed that “... in changing world from the point view of globalization process the internationalization of higher education causes arising new problems and searching new ways of solving them because of theory and practice differ very often. It deals with the educational (training) process as well” [229]. "The obvious conclusion should be drawn: to achieve good results in training through the medium of English it's necessary to find out the students' objectives, to encourage students' creative thinking, to develop the new approaches to help the students to become the competitive specialists in the market of labour in the epoch of globalization with its positive and negative features"[230]. 


\subsection{Modern tools for the implementation of distance learning}

The COVID-19 pandemic has made radical adjustments to the organization of the educational process in higher education institutions. Most governments around the world, including Ukraine [231], have transferred higher education students to distance learning under quarantine restrictions in an attempt to curb the spread of the pandemic. These nationwide events affect almost $70 \%$ of the world's student population. Quarantine is not a vacation, but a new learning environment that requires the creation of modern forms of activity, where the main factors of success are the responsibility and self-organization of students and teachers.

Distance learning is a form of open learning system that provides interactive interaction of teachers and students at different stages of learning and independent work of students with the materials of the information network using modern information and communication technologies. "Distance learning in a higher education institution is a new, independent, progressive form of learning that has greater potential" [232]. Distance learning involves the creation and use of a single information and educational environment, which contains various electronic sources of information, namely: distance learning courses; electronic textbooks located on educational servers; virtual libraries; databases of educational resources; web-quests designed to achieve learning objectives; virtual environments of educational and practical activity (laboratory works, workshops); electronic simulators; electronic systems for monitoring and measuring the effectiveness of training [233].

The Moodle (Modular Object-Oriented Dynamic Learning Environment) learning platform was chosen as the only information and educational environment [234, 235]. The Moodle platform meets all the requirements of the organization of lifelong learning in order to obtain professional competencies and includes the following interrelated stages: diagnosis, planning, training, management of the educational process, assessment, communication of results [236]. Moodle learning environment allows to provide asynchronous independent work of students of higher education institution, aimed at solving the system of educational tasks and tasks in the process of time- 
distributed interactive interaction with the developing elements of this electronic learning environment [237]. This platform contains a large number of different learning elements (so-called "modules"), which provide dialogue and cooperation between teacher and students. With the help of the platform, the teacher can choose any of the modules, place it on the site, edit, and update, and use to inform, teach and evaluate students. To provide students with material for theoretical training in each discipline, a full-fledged course was created, which included lecture material, lesson plans, electronic resources, materials for independent work, test tasks. The use of multimedia video and audio materials, drawings significantly increases the effectiveness of teaching and students' interest in learning new material. Certain modules, such as Task Activities, allow the teacher to assign tasks, collect papers, evaluate them, and leave feedback on those papers. Students can send any digital content (files), such as text documents, spreadsheets, and pictures, audio and video files. In addition, you can allow students to enter the answer directly on the site. The platform allows you to monitor student activity, contains a user-friendly electronic journal of grades. The "Test" module is used to assess the student's work. This module gives the teacher the opportunity to use Bloom's taxonomy tests, which may contain questions of different types: multiple choice; essay; drag and drop in the text; short answer; numerical answer; conformity; "right and wrong." The "Test" module allows the teacher to quickly check the results of many students at once, as their answers are checked automatically and immediately entered into the journal of grades.

One of the strengths of Moodle is the wide range of communication opportunities (glossaries, blogs, forums), which are focused on the joint work of teacher and student. In forums it is possible to carry out discussions on groups, to estimate messages, to attach to them files of any formats. In personal messages and comments there is an opportunity to discuss a specific problem with the teacher in person. In the chat, the discussion takes place in real time.

Given that most of the disciplines studied in higher education are practiceoriented, teachers face an extraordinary task - to create conditions not only for the acquisition of theoretical knowledge, but also for the development of skills and 
practical skills. In addition, the teacher is primarily a speaker who needs feedback. There are many resources on the Internet with training programs that would help make distance learning as productive as possible. Based on own experience of participating in educational online webinars, it was decided to provide visual contact between teacher and student to use the ZOOM service to the distance learning platform. It is one of the leading tools for online meetings and video or audio conferences. Zoom service has a number of advantages: it is very simple and easy to use; it can be used on any gadget - phone, tablet, computer or laptop. During the broadcast, the teacher explains the task or demonstrates the practical skills that students must complete. The teacher can also demonstrate presentations with information material and videos. The teacher also has the opportunity to explain to students how and for what forms of work it is better to use the materials contained in the distance learning platform, which should be given special attention. In turn, students can also use the "screen demonstration" function to perform the tasks of the teacher. Students can ask the teacher questions or leave comments in the chat, and the teacher can answer them immediately during a lecture or practical session. An important role is played by the "video conference recording" function, which allows students who could not join the video conference to view the recording in time later. All videos can be stored on a computer or in the Zoom cloud storage. The Zoom service is available to the largest possible audience of students because it is free. Free conferences last up to 40 minutes, which is almost equivalent to an academic hour and does not require the teacher to significantly review the methodological material for lectures, practical or seminar classes.

But there are some problems when using the ZOOM service. First of all, it provides both teachers and students with powerful gadgets and high-speed Internet to support high-quality video conferencing. It should be understood that distance learning is not a tracing of full-time learning in the classroom and requires some change in the structure of the organization of the classroom - at least because attention and fatigue at the computer work completely differently. But it is no less obvious that modern distance education has emerged, formed and developed on the basis of a concept known as the "inverted class" [238, 239]. That is, when a student masters the material before 
PEDAGOGY IN MODERN CONDITIONS

the lesson and during the practical lesson together with the teacher clarifies complex issues, says what is not clear, and corrects mistakes, if any. Such a system implements the student's ability to learn independently.

Certain difficulties may arise with the identification of distance students. But both the Moodle platform and the ZOOM service require certain logins and passwords to use, which allows you to in some way ensure the identification of the student who is present at the practical lesson or lecture.

Mandatory requirements for the organization of the process of distance learning will be first of all: technical conditions, which will include computer equipment, software with sufficient characteristics, access to the Internet, as well as staffing requirements. Availability of trained teachers of the appropriate level (tutors), engineers and laboratory assistants. Attention should be paid to the need to train teachers (tutors) to use educational resources. Before the active introduction of distance learning, tutors were trained to work with the educational platform Moodle [240]. Open online courses and methodological developments were usually used to train in the ZOOM service [241].

The combination of theoretical material presented on the Moodle distance learning platform, interesting interactive tasks and video communication with the help of ZOOM service during lectures and practical classes should be a good basis for students to receive quality theoretical and practical training even in quarantine competencies inherent in the curriculum in each discipline. 


\subsection{Clil and call technology application to improve quality formation of students' foreign language communicative competence}

New economic realities determine the formation of Ukrainian teachers and their students of modern worldview and acceptance of European values, and first of all, language standards that will help them master new knowledge, their application in everyday life. So a modern teacher is not only a carrier of new knowledge for students, but first of all an organizer of educational-cognitive, educational-search, project, and productive activity with the use of information and communication technologies. Currently foreign language fluency is considered to be one of the important tools for expanding professional knowledge, competence, abilities, and skills. In this regard, new teaching technologies appear in teaching a foreign language, which include subject-language integrated learning CLIL and CALL. Integrated lessons are one of the areas of modern high school that promote development creative potential of students and teachers. Intra-subject and inter-subject integration helps to overcome the fragmentation and mosaic of students' knowledge. Integration provides mastery of complex knowledge of various subjects in the study of the topics. The process of lessons integration has a general humanistic orientation, since helps students to realize their place in the social environment; to overcome the deductive approach in observing phenomena the subject under study and individualize the meaning of each studied subjects.

This methodological development is devoted to the disclosure of the concept of subject-language integrated learning using information and communication technologies to motivate students in preparation for external evaluation in English. Because motivation is one of the most influential individual variables expected to that the advantages of this approach are obvious. Rapid development of new information technologies and their implementation around the world have left a certain imprint on development personality of the modern student, so the modern high school is designed to ensure achievement such educational outcomes that would promote the development of personality and meet modern requirements of society. An individual must be 
competent in different areas of activity. The educational establishment should help students to master technology life mode, to create conditions for the disclosure of the potential of self-knowledge, self-esteem, self-regulation and self-realization. Effective learning is not possible without finding ways to enhance the cognitive activity of students.

The analysis of various methods and techniques, selected training exercises, which are aimed not only at realizing the learning goal, but also at promoting its own skills and abilities, shows the following aspects. Tasks should attract each student, to form its cognitive activity, to promote the application of a differentiated approach in learning, organization individual, and group work. The presented material should promote the production of students' ability to listen carefully and follow the teacher's instructions; quick memorization, development of logical thinking and memory, formation of cognitive activity of students, and increase the development of students' independence, their ability for cooperation.

Content and Language Integrated Learning (CLIL) subject-language technology integrated learning - introduced in 20 European countries in 2007. The term (CLIL) was given by David Marsh in 1994, who the first described it methodological approach in which the study of a foreign language is integrated. CLIL refers to situations where subjects or parts of them are studied foreign language with a dual purpose, namely the study of content with simultaneous learning a foreign language [242]. The purpose of "dual orientation" implies that CLIL works in two ways based on an integrated interdisciplinary approach. CLIL opens up more opportunities for the integration of university subjects compared to STEM education.

Modern educational methods define CLIL as a didactic technology that allows to form in pupils linguistic and communicative competences not native to students in the language in the educational context in which they are formed and development of general knowledge and skills. In planning classes based on this technology must take into account its mandatory components, called " $4 \mathrm{C}$ ": "content" (content) - to stimulate the process of learning and skills development on the subject, "communication" - to 
PEDAGOGY IN MODERN CONDITIONS

teach students use foreign language tools to gain knowledge on the subject, "cognition" (cognitive orientation) - to develop students' thinking abilities for the better understanding of language and subject, "culture" (knowledge of culturology) understanding features of individual cultures will help students to socialize more effectively in a modern multicultural society, it is better to understand one's own culture and stimulate its preservation and development [243].

CLIL technology by David Marsh and Anne Mallers is considered as follows:

- language knowledge is a means of studying the content of information (we are talking about cross-curricular approach - interdisciplinary approach);

- subject study is improved by increasing motivation to acquisition of communication skills in a foreign language - English or any other (this is a topic-based approach - thematically oriented approach);

- CLIL is based on language acquisition, not language learning (called task-based and project-based approaches to performance-based learning certain tasks and projects);

- rapid speech is more important than the mistakes that are made by students;

- reading and comprehension of speech become important for participation in the discussion [246].

It is necessary to pay attention to four factors of the CLIL technique, which have some similarities with other previous approaches to learning a foreign language. The first feature is a naturalistic and implicit style of teaching methods CLIL. In a naturalistic and implicit style CLIL training should be understood to increase communication opportunities through greater focus on the input that the student receives from the outside environment. A large amount of information provides better learning outcomes. The second feature of CLIL is the style of cooperative learning. During the joint learning students are usually divided into small groups to perform tasks through teamwork. Cooperative learning style is effective, as it gives the chance to get rid of anxiety in the course of training, to stimulate motivate students and 
promote interaction between them. Student autonomy created within the cooperative method of training, and interaction with a team member, promotes improving their sociability during language learning. The third feature of CLIL - it is an authenticity that allows students to develop problem-solving skills communication in real life.

During authentically oriented learning materials are selected taking into account the real language environment. The fourth CLIL feature is flexibility. The CLIL technique can be applied to introduction into different curricula with different content of subject research. CLIL aims to combine foreign language learning with other learning subjects (biology, physics, chemistry, history, literature, etc.).

Teachers easily conduct lessons on any of these topics as in the manual methods of using lexical-grammatical and speech content are shown all learning topics at each stage of the lesson. Texts accompanied by illustrations, presentations, and video so that students can visualize, imagine and see what they read. While working with authentic material, it is necessary to distinguish structural markers in the texts. These markers can be linguistic (headings, subheadings) and diagrams, charts, etc. Once the "basic markers" are identified, the structure of the text and the content can be analyzed.

In order for the implementation of all these elements to be rational the teacher must be sure there are ways to support students in the lesson at: a) the word level (banks words, glossaries, target language, dictionaries, visuals, realities, labels, most used words); b) the sentence level (beginning of the sentence, beginning of the question, base tables, sentences with missing words); c) the text level (charts, videos, predictions text content, sample texts, language constructions) [243]. For the organization of lexical material it is important to use diagrams to help students to classify ideas and information in the text. Chart types can be different for classification, groups, hierarchy, in the form of instructions and additional information, tables, describing people and places, as well as their combinations. Text structuring used to facilitate the learning process and create targeted activities for the development of speech skills.

Learning a foreign language is greatly simplified with the use of modern ones information and communication technologies that make it possible to combine 
PEDAGOGY IN MODERN CONDITIONS

technical and the humanities, which in its turn makes it possible to create a language environment to learn the language, combine traditional and innovative methods of language learning. CALL (Computer Assisted Language Learning) received the widest distribution to denote the whole set of research related using computers in foreign language teaching.

The goal of most systems is to develop not only linguistic, but also informational and communication competencies. CALL is learning foreign languages computer tools which offer a wide range of software for all available forms of foreign language teaching. Since the mid- 80 of the twentieth century a scientific school was formed that provided computer support for language learning called Computer-Assisted Language Learning. CALL is defined as an approach to teaching languages, where the computer acts as an auxiliary tool for representation and material evaluation.

According to the modern concept by Ewa Golonka, Anita Bowles, Victor Frank, CALL is not considered an independent method of teaching foreigners languages, and is used as one of the technical means of intensification and improvement of classroom and independent work [245].

New training systems are based on computer systems equipped specialized training programs. It already exists both abroad and in Ukraine some experience in using such systems, as evidenced by T. Sidorenko, L.Masliuk, P. Gurevich and others. [241]. They distinguish the following training systems: 1) training programs; 2) test programs; 3) multimedia educational programs; 4) game programs; 5) Internet databases; 6) communication software tools. Multimedia training programs are focused on independent and for classroom work. An integral part of such systems is multimedia - information and communication technology that allows to combine information digital (texts, graphics, and animation), analogue visual information display (video, photos, pictures, etc.) and analogue audio information (speech, music or other sounds).

To do this we need to create a powerful information and educational environment for learning a foreign language, which to some extent will replace printed teaching aids. Creation of interactive educational and methodical complexes for 
learning foreign languages would help to form a foreign language communicative competence of students, starting from secondary school; and creation of computer and network textbooks in different foreign languages, which would consist of several training modules that would have a specific purpose. For example, information and grammar module will provide comprehensive information grammatical nature and then passing the training module will allow develop grammar skills that will be tested during the module control, and in case of insufficient level of grammar skills will return to previous modules. In addition we need to create computer and network lexicalgrammatical, lexical simulators for independent work of students, which will deepen their foreign language lexical and grammatical skills at the primary and basic level.

Creating test programs for conducting current and final control of the level of formation of a foreign language communicative competence in all types of speech activity would be necessary. Educational games would also correspond to foreign language curricula the relevant group at the university. Such educational games, based on the natural interest of students in computer games, will help to master lexical material, develop listening skills, form grammatical skills, and develop socio-cultural competence. However, the fastest growing segment of CALL resources is web quests, quizzes, games and forms for their creation with the ability to track achievements students when using them (Web Quest about Web Quest; Hot Potatoes, etc.). One more type CALL -grammar exercises on the website of the publishers who accompany traditional textbooks and include an electronic version of test tasks on the topics of the manual (filling in the missing words in sentences, questions from multiple choice answers).Virtual classrooms are also commercial, which may partially offer materials in free access. Useful in addition to CALL text formats are audio and video resources, and some modern ones involve interactive programs for voice recording and recognition student languages.

Thus the development and comprehensive dissemination of information and communication technologies have led to systemic changes in the educational environment in general, and in the system foreign language teaching in particular. 
Therefore the most relevant for this is the formation willingness and ability to create and manage their own learning content that will meet the needs of each student.

CLIL is an innovative approach to learning that involves creating a holistic dynamic and motivating environment. It gives the opportunity not individually teach different subjects and integrate them with others. Students observe the similarities and differences in various fields of knowledge. So learners have the opportunity to learn better and understand the culture of the language being studied, which leads to the formation of socio-cultural competencies. The students pass through a fairly large amount of language material, which is a full immersion in the natural language environment.

It should also be noted that work on various topics allows us to study specific terms defined by language constructions, which contributes replenish the students' vocabulary with subject terminology and prepares them for further study and application of the acquired knowledge and skills in the preparation of external evaluation. In the transformation of teaching methods a technological approach is used, based on the analysis of changes in computer technology and software.

The current stage of e-learning English as a foreign language is characterized by the development of Internet technologies and mobile applications. Listed examples of effective methods of teaching foreign languages with application computers that evolve from authentic text to hypertext and multimedia learning environments, and support the development of four language skills - reading, writing, speaking and listening. This trend is interrelated with phenomenon that characterizes active users of gadgets "Internet-based communicative behavior", when not only the students but also the teachers are able to combine their actions performed simultaneously in real and virtual spaces.

In modern conditions of educational services market development in Ukraine, great attention should be paid to preparing students for external evaluation, which is for them starting point for further higher education and special qualification skills. These technologies are aimed at development independent, systematic, logical, critical 
PEDAGOGY IN MODERN CONDITIONS

and creative thinking of the students and summarize and systematize the accumulated knowledge of English and others items. Among those analyzed positive aspects of the above methods (CLIL, CALL) should be noted increased motivation to learn a foreign language, determination to master a foreign language to solve specific communicative tasks, priority of development of communication skills in a foreign language in a professional context, immersion in the created language environment, learning specific terms, certain language constructions and vocabulary expansion stock, which is an integral part of preparing students to be a competent, highly qualified, and competitive specialist. 


\subsection{Comparative analysis of translator training in higher educational institutions of Ukraine and Spain}

The development of modern society in conditions of high quality education requires an increase in the amount of knowledge and skills of higher education graduates. Learning a foreign language has long been an integral part of the curriculum of any higher education institution. Therefore, in the context of new civilizational challenges, more and more countries around the world use this knowledge as a driving force of social progress. To significantly increase the competitiveness of the European system of science and higher education in the global dimension, increase its role in social transformation, European countries have decided to deepen integration processes in science and education, consolidate the efforts of scientific and educational community and governments to implement rapprochement and harmonization of educational systems of European countries [246]. This process was called Bologna.

Europe's accession to the Bologna Process led to the introduction of radicals

changes in education. And Ukraine's integration into the European educational space has led to an increase in demand for learning foreign languages. This, in turn, led to a reform of the professional training of future translators for highly qualified professional activities. Taking into account foreign experience in this field of vocational education will provide an opportunity to improve the quality of professional training of translators in higher educational institutions of Ukraine. Review of the development of training programs in the field of translation in the global context and a detailed analysis of the situation at the present stage of their operation will help solve the problem of improving programs and technologies for training translators in Ukraine and adapting them to the world educational space.

Translation disciplines are an integral part of a large part of training programs in various fields of education. From the 1990s, translator training programs began to be actively separated from general language specialization programs. Thus, the professional training of future translators in universities around the world is carried out in two main types of curricula: full higher education programs with a duration of study usually 5 years and consecutive degrees (educational qualification levels) bachelor, 
master (in Ukraine - bachelor, specialist, master's degree); master's programs, which operate independently of the bachelor's degree and provide 2 (rarely 1) years of study for students who have already received a bachelor's degree in the relevant field of knowledge.

The first scheme of training prevails in many European countries (Spain, Austria, Germany), in Turkey bachelor's programs with a term of study of 4 years dominate. In other countries of the world independent master's programs of training of translators (France, the USA, the Great Britain) are widespread. This situation is explained by the intensive study of foreign languages in non-philological training programs. .

Although Spain is one of the initiators and active participants in the process of European integration in the field of education, the country is quite cautiously reforming its own system of higher education in the context of the Bologna Process, seeking to preserve its national educational traditions. The reform processes in Spain, aimed at improving the quality and competitiveness of its higher education in the world and expanding the mobility of students and teachers, have already yielded some results. In 1998, the Framework Law on Higher Education was amended to set out the minimum requirements for the implementation of the Bologna Declaration, giving them the status of complementary to the national education system. Thus, higher education institutions in Spain were given the right to choose the system of training students for both classical Spanish and the new European version of the training of bachelors and masters [247].

New for higher education in Spain was the introduction of a bachelor's and master's degree (master's degree) in the pan-European sense, which faces a number of problems and is accompanied by discussions in the country itself. In higher education in Spain there are structural changes, development and testing of new approaches, models, technologies of preparation of future experts, in particular translators.

To achieve high student mobility, which is a key requirement of the Bologna Declaration, undergraduate translation majors in Germany have similar curricula. Bachelor's programs are divided into cycles (humanitarian, social, economic, professional) and sections (physical culture, training and production practice, state certification). 
Each cycle has a basic mandatory part and a variable (profile) part, which is determined by the university. It is the variable part that should provide students with the opportunity to gain in-depth knowledge and skills for successful professional activities and prepare them for further study in the master's program. The training is based on general philological education in two foreign languages, which is supplemented by seminars on translation and introduction to one of the areas of specialization (engineering, law, natural sciences, medicine, economics) and general linguistic and cultural disciplines. All universities offer computer courses and courses in information technology. The learning process is not as academic as in domestic universities, more flexible and focused on individual needs and interests of students, which meets the needs of the European labor market and takes into account current and future practical challenges that students will face in their future careers. The bachelor's exam consists of a written bachelor's thesis and an oral final exam.

To enter the master's program, it is necessary not only to obtain a bachelor's degree in translation, but also to pass an entrance exam, which increases the level of master's translation education. A characteristic feature of independent master's specialties is their profile specialization. They are aimed at meeting the specific needs of the translation services market and provide for the availability of specialized disciplines that provide additional knowledge in the field of future professional activity. Master's degree programs in translation provide two stages of training. The first stage of the educational process includes general disciplines (usually the basics

translation and interpretation). The second stage involves the study of specialized disciplines, which depend on the chosen direction of training.

Many professionals and school administrations are not entirely satisfied with the current model of education, which does not fully meet the needs of the modern information society. You can often hear critical thoughts about the loss of quality of education and the lack of attractiveness of training translators in universities. There is a prevailing opinion that more attention should be paid to the disciplines of specialization during the training of translators, as today translators are being pushed out of the labor market by specialists from other fields of knowledge with a foreign 
language or additional qualification in translation. There are more and more opinions that both in bachelor's and master's programs philological disciplines should not dominate over special and general language subjects, disciplines in translatory and culturology. In Spanish universities, more attention is paid to new requirements for the professional activity of a translator or already established areas activities such as software localization, intercultural, technical correspondence, social representation, intercultural conflict management, as well as preparing students for the special conditions and requirements of relay (retransmission) translation, the widespread introduction of new speech technologies and other aids, development and development group work skills.

Translation - reproduction of the original oral or written message (in the broadest sense of the word) by means of another language while maintaining the unity of content and form. Translator (in a broad sense) - an intermediate link in communication, the need for which arises in cases where the codes used by the source and recipient do not match; in the narrow sense - a person who is professionally engaged in translation [247]. Thus, translation is a holistic transmission of the content of what has been said, not words, grammatical constructions or other means of the original language are translated, but the thoughts and content of the original. Therefore, during the professional training of translators in Spain there is a consistent adaptation of translation training to the requirements of the developing information society, which covers the following points:

- emphasis on professional specialization and training of future translators within the catalog of additional specialties, which is constantly expanding and updated;

- expanding the offer of disciplines in the field of information technology, acquainting students with the technical capabilities of communication technologies in order to best prepare students for the requirements and consequences of political and scientific globalization;

- emphasis on the scientific nature of translation training due to the introduction of disciplines in translatory, intercultural communication, linguistics; 
- teaching that focuses on language typologies and universals to ensure further specialization in a particular language and culture, deepening the level of knowledge of language disciplines.

Today, the mediator is expected to have knowledge, skills and abilities that are not directly related to the profession of translator: independent compilation of texts (not only correspondence or protocols, but also technical, popular science, journalism), evaluation, reviewing texts, creating adapted versions software (localization), text editing, text processing for further machine translation, machine translation processing, consultations not only on language issues, but also on local lore and intercultural aspects, etc. Therefore, in the Spanish system of training translators in the professional profile includes a variety of professional activities. The requirements for a professional translator are very diverse. The future translator must have a broad background knowledge, progressive competence in native and foreign languages, knowledge of translation theory and strategies, knowledge and skills in the field of translation analysis, source analysis, skills of creating text in the language of translation and its layout, have the necessary information methods. , including independent work with terminology, knowledge of the features of the professional activity of the language mediator.

Curricula at Spanish universities that train translators are based on the already established common language competence of students, which is further improved in the process of training future translators. According to Spanish didactics and methodologists, it is unacceptable that the basic language competence is not formed before starting university and that such a situation is the result of the widespread opinion that knowledge of a foreign language is important for the profession of translator. As a result, there is often a lack of coordination between specialization classes and interpretation and translation classes, where these acquired special knowledge must be applied in practice.

Special attention in the Spanish system of training specialists in interpretation and translation is paid to testing the professional suitability of students for the profession of translator, because future translators must have a number of personal qualities: 
special logical thinking, ability to analyze; creativity, which is necessary when creating the final text, as well as when translating complex texts, when the usual translation strategies are not enough; intuition, ie direct, complete, unfounded understanding and recognition; conscious critical position, ability to self-criticism; the ability to quickly adapt to a new activity, the willingness to constantly learn something new, which is associated with constant motivation and interest in the world around; high readiness and ability to communicate, which implies good speech, openness, ability to argue.

To test the level of speech competence, many schools have introduced various forms of written and oral tests, such as synonymy, antonymy, paraphrasing, summarizing, and other transformational tasks, error recognition tasks, and essay writing. In this way, general speech competence, associative memory, inductive speech abilities are tested.

Summarizing the above, it should be noted that a positive aspect in the training of future translators in Spanish universities, in our opinion, is a clear focus of the learning process on current and future practical challenges that students will face in their professional activities. This, in particular, is a clear professional orientation of master's programs and the provision of bachelor's programs in general philological education. The content of curricula in translation specialties meets the needs of the European labor market and globalization processes, because they contain all disciplines, the study of which leads to the formation of translation competence. Advantage practical classes, a relatively low percentage of theoretical disciplines, their optimal coordination, the professional experience of translators of the teaching staff provide students with high chances in the labor market. It is important for Ukraine to make the most of these positive aspects of the Spanish experience of the system of training future translators.

Ukraine's education system is in the process of reform. The implementation of the new Concept of the organization of master's training in Ukraine will significantly affect the process of professional training of translators in higher education institutions. The transition to a two-tier education system with bachelor's and master's degrees will create the need to review and adjust training programs and translation specialties. As foreign practice shows, the leading place in the system of translator training should be 
occupied by specialized programs, as they are designed to train qualified specialists who can meet the needs of professional translation of specific segments of the translation services market.

It should be noted that the interest in the translation profession can be traced back to the early stages of development of civilized society. Professional training programs for translators in the global context tend to specialize. Their main types are: full higher education programs and independent master's programs of a specialized nature. An important achievement of translation programs is the involvement in the educational process of specialized disciplines that allow to obtain the necessary knowledge in the field of specialization. The development of computer skills in professional activities makes a significant contribution to the process of improving the quality of education. It is important for Ukraine to review the training programs for translators, taking into account global trends in the specialization of translation activities and to make the most of the positive aspects of foreign experience in the system of training specialists with educational qualifications bachelor, master, in particular, the experience of Spain, which occupies a leading position among the leading countries with a high level of training of qualified translation professionals. Review of the development of programs of modern trends in the field of translation in the global context and a detailed analysis of the situation at the present stage of their operation would help solve the problem of improving programs and technologies for training translators in Ukraine and adapting them to global educational space. 


\subsection{On some gender and cultural communicative issues}

This paper draws on the sounds, and images that dwell in authentic texts and, afterwards, drift into the EFL classroom. Children as well as adult learners tend to show a dynamic interest in the material: a sparkled curiosity grows into a steady interest which, in its turn, develops into the ability to observe the ways of conveying meanings in the native and foreign languages. Interjections, sound imitations, fabulous images, and metaphoric associations can be solely enjoyed when they appear naturally in meaningful texts. Scattered sparingly in in-and-out of classroom reading, these issues can hardly undergo the teacher's planning. But, whenever the teacher has a text full of sounds and images, a subtle and relevant cross-cultural comparison can sustain the learners' susceptibility to new meanings.

For a decade of teaching EFL, I have been collecting - keeping to myself - special moments when students' eyes sparkled. Most cases are not the usual topics in EFL/ESL professional literature: and they are not students' immediate needs. Still, seemingly useless, they do enliven the classes, bringing in some modicum of meaning, emotion, sound and colour. Two of them are the most salient.

Interjections and sound imitations.

Adults and children react equally enthusiastically to the discovery that sounds are described in different ways in English and Ukrainian/Russian. Advanced and midintermediate student teachers were curious to encounter abundant interjections in the collection of stories $<$ Sixteen $>$ ( Ed. by R.Gallo. Dell books).

They mimicked-pronounced, pronounced-mimicked $<$ Yuck! $>$ that seems far less disgusting than their native $<$ fu-u-u-u! $>$ in combination with the wrinkled nose; < Shoo $>$ happens to mean the same as Russian/Ukrainian $<$ Bryss' ! $>$; $<$ Wow $>$ impresses as much shorter and brighter than well-practiced $<$ Uh-u-u-u-u! $>$ or $<$ Nu-u-u da-a-a! $>$

From that time on through semesters of reading and between other important things, some learners were keeping lists of English interjections. Sounds entered the students' essays. The culmination was a girl's paper on how to apply sounds of different origin in the classroom activities, in particular, role-play. 
Two implications figure out of this incidental fun - the students collected, those who did, the issues on their own initiative, and they could distinctly remember the passages from the original text where the sounds occurred. The pieces of the text: < Craig's mother glares at the photographer. $<$ Shoo! $>$ she says, waving her hand $<$ Shoo immediately! $>$ (Sixteen, p.18), or $<$ Hey, I could embroider YUCK on it and give it to Sharon for a diaper bag > (ibid ., p.49), or < Oh, wow, Nancy's party? Oh, wow, this is really a surprise...Hmmm. Wow...> (ibid., 80) were fired away without a minute's hesitation. Furthermore, the sections of the surrounding text were paraphrased with relative accuracy and ease.

Enthusiastic as much as adults, children enjoy other sounds. On the pages of the books, they discover that English-American- Australian pigs, cows, and other beasts produce sounds different from their Ukrainian-Russian counterparts'. English-hearing dogs $<$ Bow- bow $>$, while their Ukrainian/Russian peers $<$ Gav-gav $>$. Crows from English speaking parts of the world $<$ Cro-o-cro $>$ as if having a mouthful of food; at this, Ukrainian/Russian ones $<\mathrm{Ca}$-a-ar $>$ hungrily and piercingly at the tip of the empty beak. Do they really sound different, or do the languages give the same sounds in different ways? Then, why? These are quite expected children's questions.

From the interest in the difference the children can spring to some creativity. My 6-year-old son's hit, which he has tried on my American and Canadian University colleagues, is the changed lines from $<$ Get ready $>$ by Felicity Hopkins: $<1$ have a plane zoom - zoom my plane; listen to my little plane. I have a plane zoom- zoom my plane; my plane, zoom, zoom, my plane...>; he dedicated it to all possible animals, vehicles, and even utensils, making the poem virtually endless.

The idea has appeared to be productive in my teaching very young learners. Surprisingly, the rhythm of the original lines welcomes any kind of substitutions accompanied by the specific sound imitation, like $<$ I have a tap/faucet. Pitter-patter my tap/faucet... $>$ ( while in the native language the sound is described $<$ kap-kap $>$ ), or $<$ I have a telephone. Buz-buz my telephone... $>$ (while in the native language $-<$ dzyn - dzyn $>$ ), etc. Great fun at first sight, this exercise contributes much to the vocabulary and pronunciation, and in embryo, to the cultural sensitivity. 
THE GENDER of animated things, animals, and fabulous images 1 which in most cases is DIFFERENT from the learners' expectations is another cause of children's and adults' sparkling eyes.

The future EFL teachers $<$ Eureka! $>$-ed when they found out that O.Wilde's Nightingale can be SHE, and moreover - a singer (O.Wilde. The Nightingale and the Rose). They had firmly believed that the vocal accomplishment is exclusively ascribed to Ukrainian/Russian HE-/ Nightingales, and exceptionally for a time when they are trying to ingratiate themselves with their lady-birds.

O.Wilde could not have known that his Lizard is able to move tears of laughter: « Why is he weeping? >asked a little Green Lizard, as he ran past him with his tail in the air <How very ridiculous! $>$ and the little Lizard, who was something of a cynic, laughed outright> (ibid., p.41). Compare, Ukrainian/ Russian SHE-Lizard is a beauty of wisdom and resiliency. Evidently, because of these assets' of hers, she was promoted - to the utter horror and sufferings of men working in the mines - to tsarina of the Urals in Bazhov's fairy tales.

Then why Love, Philosophy, and Power by O.Wilde are HE, while in Ukrainian/Russian they are of the feminine gender? The grammatical perception is supported by the evoked images. Three beautiful ladies, always together, represent Slavonic names Vera, Nadezhda and Lubov which stand for Trust, Hope, and Love. Ukrainian/Russian Power, unfortunately, is also with woman's looks; and 1 might add, they are far from enviable ones: somewhat rotund, insensitive, and potentially violent. Philosophy is visualized as a dry, and yellow, and annoying spinster, with a revolver added to a communist version of it.

To explain to children the shift in fairy-tale personages' gender takes great pains; but as soon as the young learners agree to the idea that, for instance, a familiar long legged jerk, unfolding like a carpenter's ruler, HE- grasshopper, can turn into a graceful girl (<The Grasshopper's song > O.Cardoso Translated by Mary Todd), they begin to observe the things that are contrary to their expectations and enjoy own findings. The children like the cases of difference as much as of similarity. They happily recognize the well-known He-hare: << Maybe I'll meet a friend $>$ he thought to himself. Maybe 
you will. $<$ Perhaps I'll meet a girl friend. $>$ He leapt in the air for joy.> (The Hare, by Emil Girleanu. Brown Watson. London., p.6). And they are likewise pleased with finding an unusual association, which is also their little achievement: < Some people say that ducks are always widows, for they think they are always grumbling and quacking to themselves.> (In my courtyard, by Emil Girleanu, ibid.,p.7).

Allegoric texts do not constitute much of EFL students' reading; novels by contemporary authors, enjoyed in and out of the classroom, give an assortment of literary issues of a slightly different origin but with the similarly intriguing EFL classroom effect. These are metaphoric animals' names.

Calling someone a dog, a crab, a ferret, or the like can be interpreted in different ways in different languages, evoking images of different connotation and emotional load. That is how < I am scared the other fellars're going to think I married a dog.> about exquisite Tracy in the happiest of times, sounds extremely rude to Ukrainian/Russian ears (Irwin Shaw. The top of the hill, p 9). However, $<$ a crab $>$ as a teacher's appellation was secretly adopted by Ukrainian/Russian students: $<$ l've never seen a teacher like you, eh, Kenny? Every one of the teachers at our school are crabs, except maybe for Mrs. Lewis $>$ ( Sixteen, ibid., p. 121). The reaction was tacitly triumphant: Ah! It is another way to give credit to teachers! And lastly, $<$ a ferret $>$ in $<\ldots$ we are trained ferrets, armed with computers; statistics, expertise, coldness of heart.> (Irwin Shaw, ibid., p. 31) is conceivable, but speakers of Ukrainian/Russian would employ the image of the dog for much the same purpose.

For everyday teaching, the following is essential. Metaphoric animals' names are innocuously amusing or puzzling, while in reading, but there are prospects that the knowledge can find an outlet in communication. Then, it is better to warn the students about entering a dangerous area: the possibility that animals' metaphoric names can compliment the partner is slim to nonexistent, but the chances to get into trouble are granted. In this language domain-the one for the native speakers -the learners should behave no more than observing and understanding guests.

Metaphoric animals' names in the shape of pet-names that loving parents use 
towards their little are especially intriguing to young learners. However adults' intentions are akin, $<\mathrm{Kid}>,<$ Pussy $>,<$ Trout $>$, or $<$ Chick $>$ in English are evidently not the same as common tender names in Ukrainian/Russian corresponding to $<$ Fish $>$, $<$ Bird $>,<$ Hare $>$, or $<$ Rabbit $>$. In a different degree agreeable images arising behind the words are able to explain why a child from one culture cannot like the name borrowed from the other. Though this material is of enormous interest to children, it is not for a regular use in the classroom: the teacher should not depend on literary texts for this topic to start, he/she had better initiate the talk themselves whenever some icebreaking device is needed. Then, probably, he/she will discover that the list of such names can be much longer because there are parents with unusual imagination, uttering adoringly to their offspring $<$ My Toad, or Elephant, or Giraffe, or Pigeon $>$, with a diminutive suffix added at times. Or the collection of tender words can expand because the children's perception is heavily affected by the books and films that are popular at the moment, and owing to which they feel comfortable being called $<$ My Dalmatian, Poodle, Whale, Dolphin, Duck, or even Dinosaur $>$ with the variants $<$ My Octopus, Python, Mouse, Crocodile, Parrot, and even Shark $>$, that are close to the Ukrainian/Russian TV and book reality. The readers might think $<$ What are they doing in their classrooms? $>$ Sure, the described things are not the objective, but they are able, not ignored, to flavour analytical, mechanical, and occasionally boring atmosphere of any classroom. Lightweight on the surface, varying ways to depict sounds, emotions, and images in different languages are the issues of culture, and if the learners feel they like them - so much the better for the language learning. 
PEDAGOGY IN MODERN CONDITIONS

\subsection{The development of professional writing skills during English for Specific Purposes Courses for future information technology specialists}

Nowadays the modern development of the information technology labour market is characterized by tough competition and higher requirements for the English language competence of the higher schools' graduates. In many cases, employers (Microsoft, Twitter group, Google Company) prefer highly qualified information technology specialists (IT-specialists) who can speak and write in the English language fluently and accurately to perform their professional activities effectively. As far as IT specialists are employed at international enterprises among their professional activities is communication with foreign experts, service and technical documentation writing, reading of scientific and technical English journals. During the lockdown period in 2020 professional written communication with foreign experts determine the importance of the development and improvement of written communication skills of future IT specialists. The online participation of IT specialists in various scientific and practical seminars and conferences, work with complex software and hardware, written communication with foreign colleagues on professional topics give rise to the development of the written communication skills of future IT specialists along with the development of reading, speaking, and listening skills.

The current information society is characterized by the continuing development of new computer technologies and telecommunications that requires appropriate professional training and professional communicative competence (PCC) of IT specialists working with new software and hardware systems.

Recent findings (John, 2018; 2. Henry-Nickie, M., Frimpong, K. and Sun H., 2019) regarding the development of information technology have let to result that the development of competence in English for Specific Purposes (ESP) of future IT specialists is considered as an urgent issue. Professional communication of IT specialists has several features that must be taken into account during the development of their writing skills during professional communicative competence.

Professional communication in the HUMAN-TO-MACHINE interaction (Aue (Sukis), 2018) has its distinctive characteristics, and in order to highlight the structure 
PEDAGOGY IN MODERN CONDITIONS

of the professional communicative competence of a specialist in the field of information technology, it is necessary to take into account the peculiarities of the professional activity of such specialists. There are no concerns that aspects of the traditionally considered structure of professional communicative competence that is present in most professions of the HUMAN-TO-HUMAN interaction cannot be automatically transferred to the specialists belong to the HUMAN-TO-MACHINE interaction.

Thus, IT specialists who develop algorithms and software can be divided into three types. The first type of work with operating systems, interfaces, and networks. Second type dealing with the design of special programs that are used for the work in different organizations, for example, $\mathrm{C} 1$ for accountants. The third type of work with global networks, write dynamic web pages, create web interfaces for databases, etc.

The analysis of the specifics of the professional activities of IT specialists made it possible to outline that a distinctive feature of IT specialists' written communication is a special communication channel, which is a computer. Since the field of the professional activity of IT specialists implies the collection, processing, storage, transmission, and retrieving of information, organizing of information transmission channels, designing of modern means and methods of information protection in global and local networks, all types of IT specialists professional activities closely connected with written communication.

New approaches to ESP teaching involve a combination of the content, organization, and learning outcomes and are aimed at the social order. It assumes the ability to work with English professional literature to get information about new technologies, discoveries, and inventions; the acquisition of knowledge about trends of modern development in science, technology, and manufacturing; the ability to conduct professional written communication with foreign partners and customers; the possession of knowledge about foreign culture and the norms of intercultural communication. The development of professional written communication skills during the ESP course is aimed at hard skills that are intricately connected with the 
PEDAGOGY IN MODERN CONDITIONS

professional activities of IT specialists and soft skills that deal with a wide context of intercultural written communication and professional cooperation.

To develop the professional communicative competence of IT specialists is necessary to combine intrinsically various aspects covering different types of professional communication. It includes knowledge of the means and methods of professional interaction organisation, the principles of professional written communication, and special features of human-machine interaction. Considering the specifics of the professional activity of future IT specialists, the structure of their professional communicative competence in ESP writing is presented in three main aspects - cognitive, interactive, and perceptual.

The cognitive aspect examines the process of cognition of the means and methods of professional written communication. The interactive aspect studies the organization and formation of the process of written information exchange in professional fields. The perceptual aspect assumes knowledge of special features during the professional interaction between humans and technology.

Thus, being an integrated part of professional activity, professional communication in ESP writing should be considered in accordance with the principles of the competence-based approach when designing the content of IT specialist training.

The role of ESP is significantly increasing within the process of competitive IT specialists training. The latest research stays that highly developed writing skills become an integral part of the professional competence of IT specialists. It is also confirmed by the fact that all programming languages that are a means of a programmer's work are based on the lingo-grammatical constructions of the English language. The level of its proficiency depends on the speed of memorizing and interpreting the constructions of programming languages. In addition, IT specialists who can speak and write in English increase the reaction of communication with the operating system during the interactive dialogues. They can faster solve the problem of debugging and editing of a program as well as many other professional issues of IT specialists' activity. 
In 2020 due to lockdown, distance working, and distance learning the profession of IT specialist is coming to one of the first places in our society. In terms of demand, the readiness of IT specialists to communicate in the English language is not only a need but also becomes an integral attribute of their professionalism.

The last years have witnessed a huge growth in the relevance of the problem of the development of future IT specialists' communicative competence among researchers. The process of communication skills and abilities development has been widely discussed in (Enache, Crişan, 2014), as well as problems arising in professional communication (Borisova, 2013). The communicative potential of EPS is influenced by the fact that the basis of many studies aimed at the formation of soft skills during the ESP course (Simkova, Medvedchuk, Vaynahiy, 2020). There is a considerable amount of literature on the ways the improvement of the efficiency of ESP teaching using computer and information technologies (Lesiak-Bielawska, 2015). Teaching ESP in the context of the future professional activity of future IT specialists in the field of scientific interests of many specialists (Vahabi, Sadeh, 2011).

The determinant role of ESP in the subject area of information technologies as a methodological tool aimed at the development of the professional writing skills during English for Specific Purposes Courses was not highlighted.

Many contradictions precondition the need to design a system of professional communicative competence of IT specialists in general and in professional writing skills in particular in the field of information technologies. First, the contradictions between the growing role of ESP in the professional activities of IT engineers and the specifics of its study outside the context of its professional activity. The contrariety between the demand for professionally significant English-language information, its competent retransmission in the national professional field, and the low ability of IT specialists to carry out this type of activity. The inconsistency between the relevance of the development of professional communicative competence of future IT specialists in the context of social order and the undeveloped training system of students.

A recent review of the literature on this topic and the above contradictions confirm the relevance of the topic and determine the development and implementation of 
PEDAGOGY IN MODERN CONDITIONS

certain conditions in the educational process that would contribute to the effective development of professional writing skills during English for Specific Purposes Courses for future information technology specialists.

An increasing number of studies (Bissenbayeva, Ubniyazova, Saktaganov, Bimagambetova, Baytucaeva, 2013) have found that authors considered various models of professional communicative competence of a specialist, determined its subject, object, and subjective components, as well as criteria for the development of professional communicative competence.

The definition of the component composition of professional communicative competence is based on theoretical provisions on the psychological essence of an individual's activity, developed by different scientists (Chernysh, 2018) and the ideas of the joint distribution of professional activity in the learning process, developed by Davydov scientific school (Rubtsov, 2015).

The study attempts to classify existing approaches to the interpretation of the concept of professional communicative competence of future IT specialists, its structure, and methods of development. Based on the theoretical analysis of the studied literature, the professional communicative competence of IT specialists can be defined as a complex of specific personal and professional communicative knowledge, and qualities, and communication skills and abilities. It is considered as a special quality of a specialist, which is formed by several components, including functional language knowledge, subject knowledge, and pragmatic knowledge that are acquired in the process of professional communication, or specially organized training. In Zimnyaya (2004) the authors suggest that communicative competence is knowledge, skills, abilities, and numerous components associated with them, the content of which is realized in professional activity through the types of speech activity in its four forms: listening, speaking, reading and writing.

An increasing number of philosophical and psychological-pedagogical studies have found that it is possible to reveal the contradiction between interaction and communication, which until now remains unresolved, even though its various aspects 
PEDAGOGY IN MODERN CONDITIONS

have been comprehensively studied by teachers, psychologists, and scientists of other fields.

In the modern theory of interpersonal written communication, the most generalized classifications based on the distinguishments of three sides of communication: communicative, interactive, and perceptual have been widely investigated. The information and communication aspects that covering the processes of receiving and transmitting information have been studied. The regulatory and communicative aspects associated with mutual corrugation of actions have been examined. The affective and communicative aspects related to the emotional sphere of a specialist professional communication have been considered.

More recent evidence (Roco \& Bainbridge, 2004) shows that technologies of a new age in NBIC convergence (convergence of N-nano, B-bio, I-info, and C-cogn technologies) require the creation of new conditions in the work of IT specialists. It requires the implementation of multidisciplinary research, professional writing knowledge, implementation of project-based cooperation, a case study with a specific enterprise where real problems have to be solved with the help of high-tech computer technologies; and joint work of students and their facilitators during the implementation of projects launched by enterprises.

It is emphasized that activity performance in all the above technologies requires from IT specialists the possession of professional communicative competence. Professional communicative competence is present in any kind of human activity and determines the advanced nature of learning. In the information age, IT specialists who possess a high level of PCC are better prepared for professional activity in a fastchanging world, autonomous learning, and continuing professional development. In this aspect for ESP teachers, it is necessary to create the joint community, the valuable foundations, semantic aspirations, and target guidelines for learners. Thus, the paradigm of modern higher professional education, the entire learning paradigm is changing from the transfer of "ready-made knowledge" (as mentioned in the Humboldt model of education) to the modern competence model of "active learning". Modern society needs IT specialists who do not need ready-made instructions but possess 
creativity, knowledge-construction, and critical thinking skills. The structure of "readymade knowledge" education is not designed for this function.

It has been suggested by Lambin (2014) that key point of innovative economy is science, education, competencies of employees, aimed at creating, distributing, targeting the use of intellectual resources and this seems to be reliable. Toffler, A. and Toffler, H. (2006) suggest that the most important resource in the age of globalization is a communication competence that is becoming a must-have in any professional activity and focused on various forms of trans- and multinational cooperation in the implementation of technical projects of various levels.

Fig. 1 demonstrates the results of the World Economic Forum top ten skills of 2025 can be divided into several types such as problem-solving (analytical thinking and innovation, complex problem-solving, critical thinking and analysis, creativity, originality and initiative, reasoning problem solving and ideation) self-management (active learning and learning strategies, resilience, stress tolerance and flexibility), working with people (leadership and social influence), and technology use and development (technology use, monitoring and control, technology design and programming) (Future of Jobs Report, 2020).

The skills and abilities mentioned above characterize the professional communicative competence of an IT specialist working in NBIC society. IT specialists' communication competence in NBIC society becomes universal, it allows interaction within N-nano, B-bio, I-info, and C-cogn technologies, which allows them to transform their versatile professional environment into the formation of the cultural universe.

In foreign countries, the requirements for professional communicative competence are integrated into the process of IT specialists preparation through the certification systems such as ABET (USA), ESIK (UK), CEAB (Canada), IEAUST (Australia), FEANI (European Union), YABEE (Japan). 
PEDAGOGY IN MODERN CONDITIONS

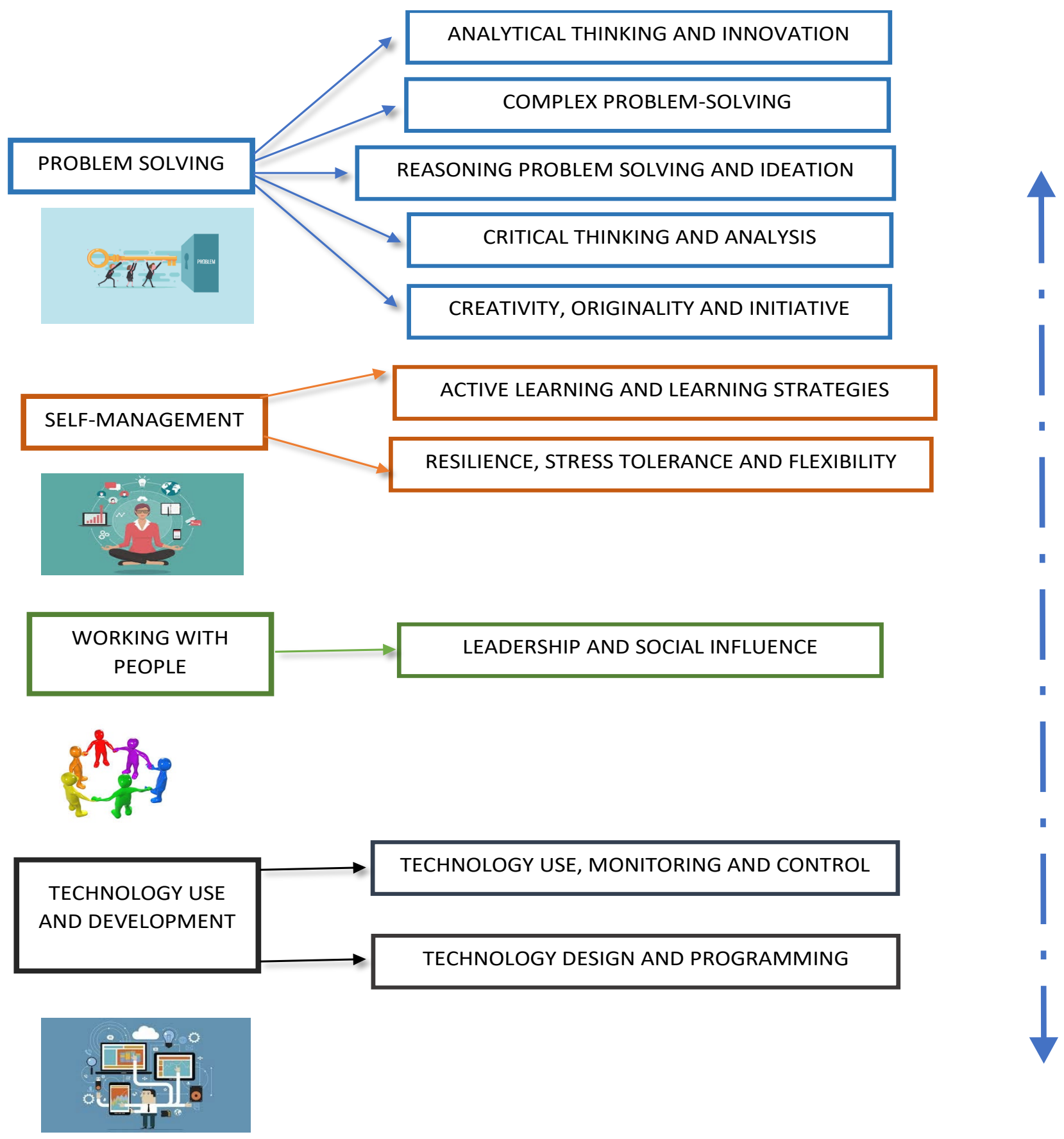

Figure 1. The forecast for main skills of the specialists in 2025

The certification is held for IT specialists with work experience from 2 to 7 years (Table 1).

It should be emphasized that in the world of science, along with professional competencies and hard skills in the field of technology (for instance, data mining, databased management, analysis, planning, design) such soft skills as the ability to 
work in a team, knowledge of effective communication (written and oral), highly developed skills and abilities EPS are highly valuable. The soft skills possession of helping future IT students improve their professional communication increase their competitiveness and chances for academic mobility.

Table 1 is revealing that the most important requirements for IT specialists despite the different level of specification is considered professional communicative competence. De Corte (2004) considering innovative learning prospects in higher education in the 21 st century, among the most important perspective emphasize the continuing expansion of own experience borders, the ability to transfer acquired knowledge and skills to new conditions and apply them to solve new professional problems in a new context. Moreover, for this, in his opinion, it is necessary to use active self-regulatory learning and modern teaching methods, based on the activation of social and professional interaction.

Table 1.

The requirements in communicative competence for the IT specialist presented in different certification systems

\begin{tabular}{|c|c|c|c|}
\hline А) & FEA & CEAB (Canada) & YABEE (Japan) \\
\hline $\begin{array}{l}\text { ability to work in an } \\
\text { international team; } \\
\text { ability to participate } \\
\text { effectively in written and } \\
\text { oral communication; } \\
\text { possess knowledge } \\
\text { about international IT } \\
\text { problems. }\end{array}$ & $\begin{array}{l}\text { possess the } \\
\text { communicative skills } \\
\text { and abilities; } \\
\text { ability to do continuing } \\
\text { professional } \\
\text { development; } \\
\text { possess European } \\
\text { language in B } 2 \text { level. }\end{array}$ & $\begin{array}{l}\text { ability to work } \\
\text { effectively; } \\
\text { ability to provide } \\
\text { effective professional } \\
\text { communication. }\end{array}$ & $\begin{array}{l}\text { possess the } \\
\text { communicative skills } \\
\text { and abilities; } \\
\text { ability to participate } \\
\text { effectively in written and } \\
\text { oral communication; } \\
\text { possess the discussion } \\
\text { skills and abilities in a } \\
\text { native and foreign } \\
\text { language. }\end{array}$ \\
\hline
\end{tabular}

Within their professional communication IT specialists should create and write different documents such as project documentation, manuals, project proposals, technical evaluations, tenders, technical tasks, management reports, grant applications, and other documents that large IT companies need. 
When describing genres of professional written communication, it is proposed to consider such as media characteristics as genre design, multimedia, hypertextuality, interactivity, synchronicity, and the number of participants and explicitness of authors.

Working with the genre design IT specialists have pay attention to the location on the screen of program elements and text such as headings, columns, lists; information automatically added to the message; the order of appearance of new messages on the screen; persistence and the size of the text, etc. Considering multimedia IT specialists should be taught how to implement the text simultaneously at several (at least two) levels, for example, transform the verbal text into the form of a sequence of words and sentences, as well as graphic elements, sound, video, and animation.

The ability of IT students to construct a text from separate blocks connected by hyperlinks when the order of perception is not strictly defined connected with the hypertextuality. Interactivity plays a great role during professional written communication as far as IT students acquire the ability to influence the reader effectively through the content, appearance, and thematic focus of a computer program or electronic resources. IT students show know how to express their opinion during written communication and learn how to perceive the opinion of a communication partner. Synchronicity implies the ability to create written messages and responses simultaneously. The number of participants (interpersonal, group, mass communication) and the explicitness of authors (an explicit or anonymous participant in the communication) play an important role in the professional written communication of IT specialists.

The genres of professional written communication of IT students can be classified according to their goals and be divided into several groups. In many cases, the informative genres include institutional webpages, including news agency webpages and online media, search engines, online encyclopedias, catalogs, mailing lists, and digital libraries. The social genres comprise chats, emails, newsgroups, forums, and social services. The directive genres include web banners, web ad pages, and online shopping web pages. Usually, the presentation genres are intricately connected with personal web pages and weblogs. Beilfus et all (2019) claim that the network novel 
PEDAGOGY IN MODERN CONDITIONS

and fanfiction belong to the aesthetic genres, and multiplayer worlds and games belong to the entertainment genres.

Our work has led us to conclude that the development of professional writing skills during ESP Courses for future IT students is an important problem facing higher education in Ukraine. The development of professional writing skills during ESP Courses for future IT students is possible on the basis of a multidisciplinary approach that combines the ESP training based on a communicative activity approach and competence-based approach providing special knowledge about professional writing communication of future IT students. This study is the first step towards enhancing our understanding of the main elements of the educational and professional discourse of IT specialists, which could be considered as a system of interrelated elements that simulate the professional discourse of IT specialists. 


\section{8 Современная лекция в медицинском последипломном образовании}

В профессиональном образовании лекция занимает одно из главенствующих мест. Лекции являются основным источником новой информации. Современная лекция меняется в результате значительного увеличения темпов накопления новых научных знаний, роста психоинформационных нагрузок учащихся, роста темпов обновления профессиональных технологий. Интерактивная лекция позволяет совместить управляющую роль преподавателя с высокой активностью учащихся на основе использования современных интерактивных технологий. Преподавание программного материала осуществляется путем активизации знаний учащихся как ретроспективных, построенных на базе междисциплинарных знаний, так и новых, которые учащийся получает во время лекции от преподавателя и самостоятельного мышления. Эффективность усвоения курса значительно повышается за счет применения мультимедийных технологий, преимуществами которых являются одновременное использование нескольких каналов восприятия учащихся - активизация визуального канала, возможности создания динамических наглядных учебных материалов, трехмерной визуализации учебных объектов и так далее. Мобильность информации, возможность копирования и размножения информации улучшают качество усвоения материала. Главными критериями педагогической и психологической эффективности лекции являются следующие: активизация у слушателей заинтересованности и мотивации, проявление эмоциональной реакции через удивление, парадоксальность, возникновение познавательной потребности в дальнейшем самостоятельном поиске, толчок в профессиональном развитии личности врача под влиянием специалиста преподавателя. Мультимедийная презентация лекций проводится при минимальном количестве слайдов с максимальной краткостью фраз и их информативностью. Тщательная предварительная подготовка к лекции, использование различных ее типов, с включением элементов импровизации может существенно улучшить 
преподнесение лекционного материала, a, следовательно, и качество последипломной подготовки врачей.

Появление новых методов диагностики заболеваний, разработка новых схем и протоколов лечения, подходов к профилактике, внедрение в лечебную практику новых лекарственных препаратов, расширение опыта использования уже известных фармакологических средств, выявление их побочных эффектов, диктует необходимость постоянного совершенствования профессиональных знаний врачей [273 - 282]. Без сомнения, соответствие содержания образовательных программ уровню развития и внедрения медицинских технологий должно быть обеспечено регулярным и своевременным их обновленим, пересмотром национальных руководств, клинических рекомендаций и унифицированных клинических протоколов [283, 284]. В настоящее время наиболее приемлемой формой последипломного обучения врачей-гематологов и трансфузиологов являються циклы тематического усовершенствования (ЦТУ) с отрывом от работы [285, 286]. Внедряються дистанционные формы обучения. На наш взгляд, особого внимания заслуживает обсуждение лекции как формы обучения в последипломном образовании врачей. Лекция является основным источником новой информации. Учитывая ежедневное увеличение новой медицинской информации, количество лекционных часов на этапе последипломного профессионального образования явно недостаточно для рассмотрения наиболее проблемных вопросов, требующих глубокого осмысления и выработки логически обоснованных выводов, базирующихся на принципах доказательной медицины.

Для преподавателя, работающего в системе последипломного образования, лекция является одним из видов основных форм систематических учебных занятий в преподавании как клинических, так и теоретических дисциплин [283 285]. В зависимости от цели и формы, а также методов изложения учебного материала, лекции можно разделить на: вступительные, учебные, информационные, обзорные, проблемные, открытые, итоговые (обобщающие), комплексные, клинические и т.д. [284]. Основной дидактической целью лекции 
является обеспечение ориентировочной основы для усвоения слушателями учебного материала. Целесообразно отметить, что наличие определенной доли самостоятельной работы учащихся на сегодняшний день является требованием к организации учебного процесса в высшей школе.

Лекция в системе учебного процесса выполняет целый ряд функций: информационную, стимулирующую, воспитательную, методологическую, разъяснительную, развивающую и благоприятствует активизации процессов мышления и внимания слушателей, создает предпосылки для самостоятельного изучения учебного материала по учебникам, пособиям, монографиям, руководствам, формирует мотивацию для работы в поисковых системах INTERNET [283 - 285, 280, 283].

Лекция, в зависимости от целей, должна иметь соответствующую методологическую структуру и содержать следующие элементы: введение, цель и основные вопросы рассматриваемой проблемы, изложение основного материала, выводы, позволяющие систематизировать учебный материал и подчеркнуть основную идею, ответы на вопросы слушателей и рекомендации для углубленного самостоятельного изучения темы [284]. При составлении плана проведения лекции необходимо составить перечень вопросов и ответов для интерактивного опроса слушателей.

При подготовке к лекции лектор должен четко определить цель и задачи лекции, дать название в соответствии с учебным планом и программой, составить план лекции и краткий ее конспект, перечень рекомендованной для самостоятельного изучения литературы, подготовить соответствующие иллюстративные материалы (мультимедийное сопровождение) и т.д.

На эффективность лекции положительно могут влиять: оптимальное освещение, отсутствие посторонних звуков, чистота воздуха в аудитории, удобные места для слушателей, хорошая акустика, эстетическое оформление аудитории и т.д. Основополагающим моментом успешного проведения лекции конечно же является искусство лектора (отличное знание предмета, культура речи, умение логично излагать свои мысли, кропотливая работа при подготовке 
к лекции, практика и тренинг, внешний вид, умение устанавливать контакт с аудиторией, педагогический такт.

При проведении лекционного занятия преподаватель обязан придерживаться внешнего и внутреннего регламента занятий (начало, разделы лекции, четкая структура и выполнение плана лекции, конец). Важными моментами являются: доступность изложения, объяснение новых терминов и понятий, выделение основных моментов, подведение итогов в конце каждого раздела и в конце лекции, использование технических средств обучения [283, 284].

Каждый вид лекции при подготовке требует индивидуального подхода, поскольку каждый вид лекции отличается от других по целям, содержанием и информацией. Например, во время вступительной лекции слушатели должны познакомиться с целью цикла (курса), его местом в системе обучения. Вступительная лекция обосновывает основные методологические позиции курса, определяет предмет и методы изучаемой дисциплины. Важно, чтобы была продемонстрирована связь теоретического материала из практическими аспектами. Во время вступительной лекции преподаватель имеет возможность охарактеризовать рекомендуемые к самостоятельному изучению учебники, пособия и руководства, что сориентирует врачей на дальнейшую самостоятельную работу и познакомит с методологией усвоения материала цикла (курса).

Обзорная лекция предусматривает систематизацию и обобщение, а также анализ главных проблемных вопросов по определенному курсу. Такую лекцию рекомендуют проводить в конце изучения нескольких тем или курса, поскольку она является обобщающей. Квинтэссенцией курса может быть обзорноповторительная лекция, которую читают в конце курса и отображают все основные моменты, составляющие научно-понятийную основу курса [284].

Информационная лекция преследует цель - дать главную информацию по теме в соответствии с учебным планом и программой. 
Проблемная лекция - наиболее сложный вид лекции, который требует от преподавателя глубокого владения материалом, умения обосновать ключевые проблемные вопросы темы, подачи материала в виде проблемной задачи, которая решается в ходе лекции вместе со слушателями.

Особенной структурой отличается клиническая лекция. Проведение ее требует определенной полготовки и организации учебного и лечебного процесса. Ассистент лектора накануне изучает в базовом отделении истории болезни пациентов, выбирает историю с классическим течением заболевания, готовит краткую презентацию по данному клиническому случаю. При согласии пациента возможна его демонстрация во время доклада. Завершается доклад формулированием диагноза в соответствии с современными классификациями. Данная часть лекции не должна превышать 15 минут. Далее лектор излагает основные моменты этиологии, патогенеза, клиники, классификации, диагностики и лечения заболевания, обращая внимание слушателей на особые и атипичные варианты его течения. Во время клинической лекции, как правило, проводится интерактивный опрос слушателей.

Кроме рассмотренных выше, в педагогической практике известны еще такие формы проведения лекции: лекция пресс-конференция, бинарная лекция (два лектора виде диалога рассматривают проблему), лекция-брифинг (мини-лекция до 20 минут, затем ответы на вопросы слушателей до 60 минут), лекция-беседа (предполагает диалог лектора и выступления слушателей), лекция «круглый стол» [284].

Итоговая (заключительная) лекция завершает лекционный курс, систематизирует полученные слушателями данные, подводит итоги прочитанного курса.

Современная лекция меняется в результате значительного увеличения темпов накопления новых научных знаний, роста психо-информационных нагрузок учащихся, роста темпов обновления профессиональных технологий. Интерактивная лекция позволяет совместить управляющую роль преподавателя с высокой активностью учащихся на основе использования современных 
PEDAGOGY IN MODERN CONDITIONS

интерактивных технологий. Преподавание программного материала осуществляется путем активизации знаний учащихся как ретроспективных, построенных на базе междисциплинарных знаний, так и новых, которые учащийся получает во время лекции от преподавателя и самостоятельного мышления. Эффективность усвоения курса значительно повышается за счет применения мультимедийных технологий, преимуществами которых являются одновременное использование нескольких каналов восприятия учащихся активизация визуального канала, возможности создания динамических наглядных учебных материалов, трехмерной визуализации учебных объектов и так далее. Мобильность информации, возможность копирования и размножения информации улучшают качество усвоения материала. Главными критериями педагогической и психологической эффективности лекции являются следующие: активизация у слушателей заинтересованности и мотивации, проявление эмоциональной реакции через удивление, парадоксальность, возникновение познавательной потребности в дальнейшем самостоятельном поиске, толчок в профессиональном развитии личности врача под влиянием специалиста преподавателя. Мультимедийная презентация лекций проводится при минимальном количестве слайдов с максимальной краткостью фраз и их информативностью. Тщательная предварительная подготовка к лекции, использование различных ее типов, с включением элементов импровизации может существенно улучшить преподнесение лекционного материала, $\mathrm{a}$, следовательно, и качество последипломной подготовки врачей.

Заключение. Лекция является незаменимым элементом в системе последипломной полготовки врачей. В структуре всех лекций в последипломном образования должны преобладать лекции проблемного характера, комплексные и клинические лекции. Современная лекция должна быть хорошо иллюстрированной, с применением мультимедийных технологий, использованием интерактивного опроса для лучшего усвоения материала. 


\section{9 Методика формування умінь в учнів розв'язувати фізичні задачі}

У педагогічній літературі й у практиці роботи шкіл велика увага приділяється розв'язуванню задач, зокрема розв'язуванню фізичних задач. Поряд з великим загальноосвітнім значенням задач з фізики, розв'язування їх на уроках сприяє організації самостійної роботи, під час якої найбільш повно формуються вміння й навички самостійних розрахунків, розвивається логічне мислення учнів.

Питання формування умінь розв'язувати фізичні задачі були дослідженні у працях учених різних галузей педагогічної науки: П.С. Атаманчук, О.I. Бугайов, С.П. Величко, Ю.М. Галатюк, В.Ф. Заболотний, О.І. Іваницький, А.В. Касперський, С.В. Коршак, О.І. Ляшенко, М.Т. Мартинюк, А.І. Павленко,

В.Ф. Савченко, В.П. Сергієнко, О.В. Сергєєв, В.І. Сумський, В.Д. Шарко, M.I. Шут та інших.

Водночас, у психолого-педагогічній літературі немає єдиного, загально визнаного визначення поняття «задача», що пояснюється багатоплановістю можливих підходів до цього поняття.

Для практичної діяльності учителя фізики достатньо знання істотних ознак поняття «задача»:

1. У задачі розглядається ситуація, що пов'язана із станом або поведінкою фізичних об'єктів (тіл, речовин, явищ, процесів);

2. У формулюванні задачі є запитання (вимога), відповідь на яке може бути знайдена в результаті застосування законів, правил, формул, що описують фізичні об'єкти та їх поведінку;

3. Розв'язування задачі передбачає подолання певного інтелектуального утруднення. Якщо пошук відповіді на запитання передбачає тільки відтворення вже відомого способу діяльності, то ми маємо справу не з задачею, а з вправою.

У формулюванні задачі може міститися опис ситуації та всі вихідні дані, що потрібні для отримання відповіді на поставлене запитання (вимогу) задачі. Але задача може формулюватися тільки у вигляді запитання або вимоги. У цьому 
PEDAGOGY IN MODERN CONDITIONS

випадку також відображені всі ознаки задачі, зокрема запитання (вимога) вказує на фізичний об’єкт, який треба аналізувати. У формулюванні задачі можуть бути як усі вихідні дані, так і частина їх. Відсутні дані знаходяться у процесі розв’язування задачі. Крім того в умові задачі можуть бути дані, які не використовуються під час їі розв’язування.

У методичній літературі можна зустрітися з великою кількістю назв задач. Зустрічаючись з цими назвами фізичних задач, треба знати, що вони виникли у зв’ язку з їх класифікацією за різними ознаками.

Наприклад, за змістом їх поділяють на абстрактні і конкретні, задачі 3 історичним і виробничим змістом. За способом формулювання умови задачі вони поділяються на текстові, графічні, задачі-рисунки, експериментальні. Задачі поділяються на кількісні та якісні. Існують й інші класифікації задач.

Різноманітність класифікацій задач пов'язана 3 необхідністю виявлення особливостей дій, що виконуються при аналізі умов i самого процесу їх розв’язування.

Наприклад, аналіз умови задачі, поданої у вигляді тексту, рисунка, графіку в кожному випадку має свої особливості. Відрізняються дії, що виконуються під час розв’язування задач шляхом обчислень, побудови графіків, виконання дослідів. Ці особливості розв’язування задач i $\epsilon$ предметом методичних досліджень.

Широке використання задач у викладанні фізики пояснюється наступним: пізнання, засвоєння знань про компоненти змісту шкільного курсу фізики, створення цілісного уявлення про них, включення їх у загальну систему знань, перевірка розуміння учнями вивченого неможливі без застосування того, що пізнається, в різноманітних ситуаціях; при розв'язуванні задач найбільш повно розвивається мислення та пізнавальні можливості школярів, одним із критеріїв їх сформованості є вміння розв’язування задач.

Незважаючи на різноманітність способів формулювання умов і способів розв’язування фізичних задач можна виділити узагальнений план діяльності, який визначає системи дій у цьому виді навчальної роботи. 


\section{PEDAGOGY IN MODERN CONDITIONS}

\section{I. Аналіз й усвідомлення умови задачі}

1. Читання умови задачі, iii аналіз, розділення відомого і невідомого, що подається у випадку кількісних задач у вигляді стислого запису вихідних даних, запитання або вимоги задачі за допомогою математичних символів.

2. Створення образу ситуації, що розглядається в задачі. У випадку кількісних задач умова й вимога зображуються графічно.

3. Визначення вихідного i кінцевого станів фізичного об'єкту, які розглядаються в умові задачі.

\section{II. Планування способу розв'язування}

1. Виявлення того, які фізичні об’єкти (стани, властивості, явища, процеси) розглядаються в задачі.

2. Пригадування ситуацій, 3 якими можливо зустрічалися учні, або можливість зведення їх до вже відомих.

3. Повторення закономірностей (законів, правил, формул), що описують стани, поведінку даних фізичних об'єктів.

\section{III. Виконання плану}

1. Застосування даних властивостей і закономірностей до конкретної ситуації, що розглядається в задачі.

2. Перевірка відповідності одержаних рівнянь кількості невідомих, запис додаткових умов.

3. Розв'язування системи рівнянь у загальному вигляді й одержання розрахункової формули.

4. Перевірка правильності одержаної формули.

$$
\text { IV. Аналіз одержаного результату }
$$

1. Обчислення й отримання значення шуканої величини.

2. Аналіз одержаного результату.

Найбільш загальними способами розв'язування задач $є$ аналітичний, синтетичний та їх сполучення.

Аналітичний спосіб розв'язування полягає в перетворенні складної задачі на ряд простих (аналіз). Розв'язування починається 3 пошуку закономірності 
PEDAGOGY IN MODERN CONDITIONS

(формули), яка дає безпосередньо відповідь на питання (вимогу) задачі. Потім з'ясовується, що відомо і невідомо у формулі, яку записали. Знаходять формулу, 3 якої може бути знайдена невідома величина. Ці дії продовжуються до отримання формули, до якої будуть входити усі відомі з умови або знайдені 3 довідкових таблиць величини. Після цього виконуються дії у зворотному напрямі з метою одержання обчислювальної формули.

При синтетичному способі розв'язування, воно розпочинається не 3 пошуку формули, в яку входить шукана величина, а з формул, що зв'язують указані в умові задачі величини. Розв'язування задачі розгортається поступово i продовжується до отримання формули, в яку входить шукана величина.

Конкретизується узагальнений план діяльності з розв'язування задач в алгоритмічних приписах (алгоритмах).

Алгоритм слід розуміти як систему приписів, послідовне виконання яких дозволяє розв'язати всі задачі, що відносяться до даного класу.

У процесі алгоритмічного розв'язування задачі учень повинен спочатку виявити до якого їх класу вона відноситься, щоб вибрати один з відомих йому алгоритмів.

Система приписів, з яких складається алгоритм, вказує що робити, в якому напрямі вести пошук розв'язування задачі, а як це зробити учень повинен вирішити сам. Це означає, що алгоритмічне розв'язування не $\epsilon$ простим відтворенням певних дій, воно пов'язано з активною розумовою діяльністю учнів, зокрема перенесення окремих дій на нові ситуації.

Засвоєння систем дій, що визначаються алгоритмами, не тільки скорочує час на формування вмінь розв'язувати типові задачі, а й сприяє формуванню вмінь розв'язувати нестандартні (творчі) задачі. Розв'язування останніх передбачає, що на деяких її етапах потрібно виконувати стандартизовані системи операцій, які визначаються алгоритмами.

Алгоритм повинен відображати найбільш істотні системи дій, що потрібні для розв'язування даного класу задач. Набір приписів повинен забезпечити розв’язок всіх задач даного класу. Кожний припис повинен бути зрозумілим для 


\section{PEDAGOGY IN MODERN CONDITIONS}

всіх учнів на даному етапі навчання.

Суть останньої вимоги полягає в тому, що стисле формулювання окремих вказівок може містити таку систему операцій або дій, які раніше формувалися як самостійний алгоритм.

Засвоєння алгоритму супроводжується його згортанням і у свідомості учнів формується невелика кількість узагальнених приписів.

Прикладом можуть бути дві системи алгоритмічних приписів, пов’ язаних 3 розв’язуванням задач із динаміки.

Перша система приписів:

1. Прочитати і зрозуміти умову задачі, з'ясувати якою є шукана фізична величина - кінематичною або динамічною характеристикою.

2. Якщо треба знайти масу, силу, коефіцієнт тертя, жорсткість, то спочатку визначити прискорення, користуючись кінематичними рівняннями руху. Потім визначити шукану величину, виходячи із законів динаміки.

3. Якщо треба знайти координату, переміщення, шлях, час, швидкість, то спочатку визначити прискорення, використовуючи закони динаміки. Потім визначити шукану величину, виходячи з рівнянь кінематики.

Друга система приписів:

1. Прочитавши і зрозумівши умову задачі, з’ясувати, рух якого тіла в ній розглядається.

2. Зобразити тіло і всі сили, що діють на нього.

3. Записати другий закон Ньютона у векторній формі.

4. У цьому законі замість сили записати векторну суму всіх сил, що діють на тіло.

5. Провести вісі координат. Одну вісь провести у напрямку прискорення тіла.

6. Записати рівняння другого закону Ньютона у проекціях на вісі координат.

7. Записати додаткові умови

8. Розв’язати одержану систему рівнянь. 


\section{PEDAGOGY IN MODERN CONDITIONS}

Як можна побачити, перша група приписів є узагальненням двох алгоритмів розв’язування задач на прямолінійні рухи і на закони динаміки. Друга система приписів складає алгоритм розв’язування задач на застосування законів динаміки. Але й у цьому випадку, щоб застосувати алгоритм, учні вже повинні вміти виконувати окремі вказівки.

Досвід роботи свідчить, що більшість учнів відчувають труднощі у розв’язуванні навіть простих задач з фізики за таких причин: відсутність зв’язку між діяльностями учителя й учнів під час вивчення теоретичного змісту та із застосуванням того, що вивчається, до конкретних ситуацій; безсистемністю у підборі задач, невизначеністю цілей їх розв’язування, тобто конкретизації результатів цього виду навчальної роботи; відсутністю навчання учнів методам розв’язування задач; недостатньою сформованістю в учнів математичних умінь.

Маючи на меті формування у школярів умінь розв’язування фізичних задач, треба враховувати те, що не можна досягти однакових результатів у навчанні всіх учнів. Водночас, всі учні повинні оволодіти уміннями розв’язування задач, певних їх класів (типів).

Формування цих умінь розпочинається 3 моменту висунення навчальної проблеми під час вивчення конкретного компоненту змісту шкільного курсу фізики, тому що однією з їі ознак є те, що це типова практична задача. Одночасно 3 процесом вивчення теоретичного матеріалу здійснюється процес пошуку способу розв’язування навчальної проблеми. Кінцевим етапом цього пошуку $є$ демонстрування вчителем способу розв’язування класу задач, до яких відноситься навчальна проблема. При цьому корисно використовувати такий прийом: під час розв'язування задачі вчителем учні не роблять відповідних записів у своїх зошитах; якщо потрібно, то додатково пояснюється логіка i послідовність виконання відповідних систем дій; потім усі записи з класної дошки стираються, а учням пропонується самостійно виконати ці дії; вчитель обходить робочі місця учнів і допомагає тим, у кого виникли труднощі у виконанні дій. 


\section{PEDAGOGY IN MODERN CONDITIONS}

Під час розв'язування першої задачі іноді вчителі намагаються залучити учнів до виконання відповідних дій, пояснюючи це намаганням «активізувати» діяльність учнів. При цьому не враховується той факт, що під час такої організації розв'язування першої даного класу задачі багато з учнів не сприймуть ці дії як цілісну систему.

Після розв'язування навчальної проблеми потрібно закріпити спосіб діяльності, який треба сформувати в учнів. Це здійснюється шляхом організації розв'язування задач з поступовим ускладненням як умов задач так і відповідних способів діяльності.

Формами організаиіï розв'язування задач є наступні: колективне, індивідуальне, змішане розв'язування.

Колективне розв'язування задачі може відбуватися із записами дій на класній дошці й у вигляді коментованих вправ на місцях.

Колективний розв'язок задач із записом дій на класній дошці має на меті аналіз і засвоєння систем дій, що виконуються. Іноді вчитель вимагає від усіх учнів самостійного виконання дій, забуваючи про те, що ці записи робляться для того, щоб ними могли скористуватися ті учні, у яких виникають труднощі у розв'язуванні цієї задачі, і розумінні цього розв'язку.

Послідовність дій при такій організації розв'язування задачі: учитель читає умову задачі; учень у дошки й інші учні стисло записують цю умову; після цього обов'язково учень у класної дошки повинен повторити умову задачі; потім відбувається колективний аналіз умови задачі й обговорення ходу іiі розв'язування.

Метою коментованих вправ на місцях є те, що учні повинні мислено уявити систему дій, пов'язану з розв'язуванням задачі. Один з учнів читає умову задачі, коментує свої дії, інші учні виконують ці дії у своїх зошитах.

Індивідуальне (самостійне) розв'язування задачі дозволяє учню самому виконати всі дії, зробити наступний крок в усвідомленні та закріпленні способу 


\section{PEDAGOGY IN MODERN CONDITIONS}

діяльності, що формується.

При зміманому розв 'язуванні задачі частина дій обговорюється колективно, а частина виконується індивідуально. Учитель може оперативно управляти ходом розв’язування задачі, спостерігаючи за діями учнів.

Яку кількість задач треба розв’язувати колективно або індивідуально визначається вчителем на підставі спостережень за учнями.

Структура циклу процесу навчання вказує на єдність класної й домашньої роботи учнів, яка виявляється в тому, що кожна 3 них є складовою частиною єдиного процесу засвоєння знань і формування відповідних умінь.

Формулюючи домашнє завдання, слід вказувати задачі, що обов’язкові для розв’язування всіма учнями, і додатково задачі, що розраховані на учнів, які виявляють особливий інтерес і здібності до вивчення фізики.

Плануючи розв’язування задач, потрібно обов'язково конкретизувати які системи дій формуються під час даного заняття (занять), тобто передбачити результати навчання. Для цього треба згрупувати задачі, що є у задачниках й інших навчальних посібниках.

Доцільно використовувати довготривалі завдання з розв’язування задач. Під час вивчення курсу фізики можна використовувати такий прийом: учням дається завдання з розв’ язування задач, які охоплюють певний навчальний матеріал. Усі задачі поділяються на три групи, у залежності від їх складності. Учитель вказує, уміння розв’язування якої групи задач оцінюється за якими рівнями i відповідними балами. Вказуються терміни виконання завдання. Учні можуть виконувати завдання самостійно, використовувати допомогу товаришів, батьків тощо. Головне у тому, щоб учень сам визначив завдання якої групи йому «під силу». Водночас, перед кожним учнем відкритий шлях до самовдосконалення. У терміни, що визначив учитель, виконується контрольна робота. Перед іiі виконанням учитель дає завдання учням того рівня складності, якого виявили бажання отримати конкретні школярі. Оцінюючи результати роботи, вчитель 


\section{PEDAGOGY IN MODERN CONDITIONS}

виходить із рівня складності й правильності виконання завдання, враховуючи, що учень не може отримати оцінку вище тієї, якій відповідає рівень складності задач.

Підбираючи задачі до контрольної роботи, слід у кожне завдання включити одну з задач, відповідного рівня складності, з тих, що входили у довготривале завдання.

Така організація навчально-пізнавальної діяльності сприяє розвитку креативного мислення учнів та підвищенню інтересу до вивчення фізики. 


\subsection{0 Організація навчального процесу в медичному ВНЗ}

Анотація. В роботі розглядаються сучасні можливості організації роботи студенів в вищому медичному закладі, зокрема можливості інформаційних технологій, як одного з ведучих сучасних варіантів організації пізнавальної діяльності студента. Робота присвячена пошуку нових дієвих форм поєднання різних форм навчального процесу.

Людство вступило в новий етап свого розвитку, коли інформаційні процеси стають однією з першорядних складових життєдіяльності людини, а в умовах сьогодення - одним 3 важливих варіантів навчання, тому стала актуальною проблема пошуку нових та адекватне поєднання різних форм навчального процесу. Вищі навчальні заклади активно позиціонують свій внесок в інноваційний процес, соціальний розвиток і активно розробляють інноваційні технології, які сприяють забезпеченню формування професійних умінь у студентів, зокрема й в умовах карантину. Отже вимоги сьогодення - це принципово новий, високотехнологічний підхід до процесу передачі знань, що дає можливість створення системи масового безперервного самонавчання, широкого обміну інформацією [291].

Характерними рисами в умовах сьогодення навчання $є$ :

1) інтерактивність навчання: система доставки інформації, що дозволяє налагодити зворотний зв'язок, забезпечити дієву форму діалогу та постійну підтримку; 2) індивідуалізація навчання - дозволяє реалізувати індивідуальний підхід, зокрема індивідуальний варіант опитування; 3) інформаційна забезпеченість дистанційного навчання характеризується тим, що студенти отримують доступ до комплекту необхідних навчальних матеріалів у сучасному електронному вигляді безпосередньо з серверу вищого навчального закладу, де студенти навчаються та інших інтернет-ресурсів; 4) сучасні комп'ютерні телекомунікації здатні забезпечити передачу знань та доступ до навчальної інформації на високому рівні, іноді це спрацьовує набагато ефективніше, ніж традиційні засоби навчання; 
Основний зміст освітньої діяльності медичних фахівців визначено галузевими стандартами вищої медичної освіти [294]. Самостійна робота студента (СРС) - на сьогодні один з найбільш розповсюджених варіантів, вид індивідуальної навчально-пізнавальної діяльності студентів, що здійснюються на практичних заняттях або у позааудиторний час згідно плану з навчальної дисципліни. Відповідно до "Положення про організацію навчального процесу у вищих навчальних закладах України" СРС є основним засобом оволодіння теоретичним матеріалом у час, вільний від обов'язкових навчальних занять із викладачем [290].

Кожен із видів самостійної роботи потребує від студентів напруженої інтелектуальної діяльності, ефективність якої залежить від дотримання вимог до організації розумової праці, урахування як загальних закономірностей, так і особливостей анатомо-фізіологічних та психічних процесів, притаманних конкретному індивіду. Процес організації самостійної роботи студентів передбачає врахування фізіологічних «піків» підвищеної працездатності: здебільшого 8-11 та 17-20-а години. В таки часи підвищується розумова активність, зростає гострота органів чуття та інших функціональних систем організму.

Якщо розглядати результати навчання у вищому навчальному закладі як сукупність окремих складових: отримання теоретичних знань, набуття практичних вмінь, формування конкретних навичок, а також ступінь готовності до самостійної професійної діяльності, то можна побачити, що кожна 3 цих складових в значній мірі залежить від інтелектуальних та мотиваційних особливостей кожного студента, а також можливостей для забезпечення якісної самостійної роботи з боку викладача. Пошук стандартів вищої медичної освіти є оптимальною стратегією досягнення концептуально нового рівня якості підготовки майбутніх фахівців, основою якого $є$ підготовка медичних працівників відповідно до загальноприйнятих міжнародних норм викладання 3 урахуванням особливостей та інтересів національної системи охорони здоров’я [290]. Вищі навчальні заклади повинні забезпечити опанування випускниками 
високого рівня знань, що надасть змогу вирішувати певні типові задачі при здійсненні виробничих функцій та забезпечити якісний рівень підготовки фундаментальних знань випускників [293]. Організація самостійної роботи студентів означає створення умов для планування студентом самостійної навчально-пізнавальної діяльності, виконання запропонованих викладачем та визначених самостійно завдань, самоконтролю, корекції та оцінювання знань викладачем.

Організуючи СРС, викладач повинен акцентувати увагу на конкретній меті навчально-пізнавальної роботи студентів, визначити оптимальний обсяг запропонованого матеріалу, структурувати зміст навчального матеріалу, який пропонується для самостійного опрацювання. Найбільш успішним, вважаємо, використання різних форм та методів контролю за СРС (тести різних рівнів, ситуаційні задачи, самостійне моделювання студентом клінічних ситуацій на запропоновану тему тощо), а також різні моделі навчально-методичного забезпечення (основні теми в тезах, схемах, таблицях, презентаціях, відеороліках). Головна мета СРС роботи є двоєдиною: засвоєння теоретичних знань $з$ формуванням системи інтелектуальних та професійних умінь і навичок та створення підгрунтя для самостійноі активності майбутнього лікаря.

Самостійну роботу студентів можна класифікувати за різними критеріями:

1. 3 урахуванням на місце і час проведення, характер керівництва й спосіб здійснення контролю за їі якістю з боку викладача можна виділити: а) самостійну роботу студентів на аудиторних заняттях (тести, ситуаційні задачи, моделювання клінічних ситуацій (кейс-метод)); б) позааудиторну самостійну роботу (все вище перераховані із залучанням навчальної літератури та інтернет-ресурсу); в) самостійну роботу під контролем викладача - індивідуальні заняття 3 викладачем.

2. За рівнем обов'язковості: а) обов'язкову, що є окресленою в навчальних планах та робочих програмах (підготовка до практичних та семінарських занять, підготовка та захист історій хвороб); б) бажану (участь у наукових гуртках, конференціях, підготовка наукових тез, статей, доповідей, рецензування робіт 
інших студентів тощо); в) добровільну (участь в конкурсах, олімпіадах, вікторинах, виготовлення наочності (зокрема інформаційні стенди).

3. За рівнем креативних здібностей студентів:

a) репродуктивну самостійну роботу - зазвичай здійснюється за певним зразком (розв'язування типових задач, заповнення схем (графів логічної структури), таблиць, виконання тренувальних завдань, що вимагають осмислення, запам'ятовування та відтворення раніше отриманих знань; б) реконструктивний варіант робіт, який передбачає складання планів для запропонованих тем, конспектування, створення анотацій, розв'язання клінічних завдань; в) дослідницьку самостійну роботу, що є орієнтованою на проведення наукових досліджень (експерименти, статистичні та теоретичні дослідження, аналіз та узагальнення отриманої інформації).

Одною з улюблених, у студентів, є така форма самостійної роботи, як реферування - письмовий огляд наукових та науково-популярних джерел 3 обраної теми та стислий виклад у письмовому вигляді суті опрацьованої літератури. Найвищу оцінку за таку работу, студент отримує, якщо реферат не лише висвітлює необхідну наукову інформацію, а й демонструє своє відношення до неї. Реферат має демонструвати вміння дослідника самостійно аналізувати, класифікувати та узагальнювати інформацію. Реферат може містити й критику думок, теорій. Тобто реферат - це самостійна творча робота студента, що засвідчує його знання з певної теми, розуміння основних підходів до вирішення конкретної проблеми, а також відображає власні погляди майбутнього лікаря. Тему реферату студент обирає у відповідності до рекомендацій викладача, відповідно до рівня підготовленості та здібностей, а також маючи на увазі перспективу подальшого використання реферату для написання підсумкових або конкурсних робіт (участь в студентських конференціях).

Однією з особливостей навчального процесу у сучасному медичному ВНЗ, особливо в умовах дистанційного навчання, є активне використання всіх можливостей сучасних гаджетів. Зокрема $\epsilon$ можливість забезпечення та контролю індивідуального темпу навчальної діяльності, студент має можливість 
самостійно обирати момент переходу до наступної порції навчальної інформації, задавати швидкість подання завдань. Також сучасні інформаційні технології дають можливість обирати ступінь складності навчального завдання, визначити свої можливості на різних рівнях складності, можливі прогалини у засвоєнні навчального матеріалу. Самооцінка є структурним компонентом мотиваційної діяльності, яка формується в процесі діяльності та міжособистісної взаємодії [292, 295].

Мультимедійні комп'ютерні ефекти, за допомогою яких можна демонструвати процеси і явища в медицині, забезпечують візуалізацію інформації щодо можливостей фізикального обстеження, діагностики, стратегій лікування, надання невідкладної допомоги. При викладанні клінічних дисциплін дає можливість імітації різноманітних клінічних ситуацій. Отже, використання сучасних технологій допомагає індивідуалізувати процес навчання, застосовуючи окрему методику для кожного студента, що дозволяє враховувати його базові знання, індивідуальні особливості, отже й розвивати здібності, підвищувати якість засвоєння знань.

Для підвищення ефективності супроводу самостійної роботи студентів в нашому ВНЗ, вже декілька років використовуються електронні підручники, електронні методичні вказівки, лекційний матеріал в презентаціях, тестові контролюючі завдання, електронна аудіовізуалізована наочність тощо. У студентів є можливість переглядати всі матеріали в необхідній кількості повторів в зручний час.

Комп'ютерна підтримка забезпечує можливість чітко організувати i конкретно спрямовувати самостійну навчальну діяльність студентів та досягти кращих результатів у навчанні при скороченні затрат часу. Але, формулюючи завдання на самостійну роботу, викладачеві необхідно подбати, щоб студент не міг обмежитись плагіатом, а крок за кроком виконував самостійні дії, порівняння, самостійно формулював висновки. Тому викладач повинен мотивувати студентів, допомогти формувати внутрішню потребу в постійній самостійній роботі. 


\section{PEDAGOGY IN MODERN CONDITIONS}

Вважаємо за вкрай важливе, що при опрацюванні конспекту лекцій, монографії, підручника, навчального посібника не повинно залишатися нічого нез'ясованого. Безумовно, не розібравшись хоча б в одному з елементів теми, студент не зможе надалі повноцінно засвоювати навчальний матеріал. Отже завдання викладача допомагати студенту правильно планувати самостійну роботу, раціонально використовувати час. Чіткий план, що постійно контролюється викладачем, допоможе раціонально структурувати такий вид діяльності, зосередитися на найсуттєвіших питаннях. Результати СРС надаються на перевірку викладачу у вигляді звітів з курації хворих, презентацій, тезисів конспектів, рефератів, тестів тощо.

Для перевірки результативності самостійної роботи студентів використовуємо для контролю: співбесіду за матеріалами теми, опитування на практичному занятті, «бліц-опрос»; письмове фронтальне опитування в кінці лекції або практичного заняття розв'язування ситуаційних задач та тестовий контроль, моделювання клінічної ситуації зі складанням планів діагностики та лікування тематичного хворого. Вважаємо за необхідність звертати увагу на труднощі у засвоєнні студентами інформації та типові помилки. Викладач має діагностувати рівень готовності студентів до сприйняття нового матеріалу.

Отже, в умовах ринкової економіки, яка вимагає нової моделі навчання, конкурентоспроможними будуть фахівці, які спираючись на фундаментальні знання, в реальній діяльності здатні творчо мислити та застосовувати знання в постійно змінюваних професійних (інколи й соціальних ситуаціях). Все це потребує високого рівня адекватної самооцінки та самоконтролю результатів діяльності від пари викладач-студент. 


\subsection{1 Особливості викладання суспільних наук у закладах вищої освіти}

Основна мета викладання суспільних наук іноземною мовою у ЗВО полягає у формуванні та розвитку міжкультурної професійної комунікативної компетенції.Навчальний процес організований таким чином, щоб в результаті навчання випускники дійсно володіли англійською мовою як інструментом вирішення своїх професійних завдань і як засобом розвитку своїх професійних та особистісних якостей.

Базовою метою і необхідною умовою результативності формування і розвитку міжкультурної професійної комунікативної компетенції $є$ досягнення студентами конкретного рівня володіння англійською мовою за загальноєвропейською класифікації рівнів у взаємопов'язаному навчанні всіх видах мовленнєвої діяльності, що робить іншомовну підготовку прозорою в якісному відношенні, оскільки рівні володіння іноземною мовою $\epsilon$ універсальними і не залежить від академічного або професійного контексту.

Проблема викладання англійською мовою дисциплін у ЗВО не є новою в педагогічній теорії та практиці. Проте методи їх реалізації не дали достатніх результатів. Запропонована значна кількість способів навчання студентів іншомовного фахового мовлення. Такі науковці, як Д. Бобова, Т. Денищиц, Т. Донченко, А. Нікітіна, А. Онощенко запропонували обгрунтовані системи навчання іншомовного професійного мовлення студентів різних спеціальностей на базі розвитку їхньої термінологічної компетенції. Однак, нам видається, що автори не приділили достатньої уваги розвитку лексичних умінь тих, хто навчається, оскільки їхній потенціальний словник був обмежений лише термінами, що зумовило недостатню мовленнєву практику студентів.

Окреслену проблему намагались вирішити такі методисти, як Г. Суткевич, О. Москалюк, Д. Фатєєва. Вони пропонували здійснювати підготовку студентів до фахового іншомовного спілкування засобами ділової гри, діалогуобговорення чи аналізу публічних виступів британських й американських носіїв мови . Попри істотну базу цих досліджень, поза увагою вчених залишилась 


\section{PEDAGOGY IN MODERN CONDITIONS}

проблема зміщення англійської мови з домінуючого предмета на допоміжний, що виконує функцію обслуговування професійної діяльності. Це призвело до того, що студенти могли вирішувати свої професійні завдання виключно на основі підготовленого мовлення. [296]

В умовах спонтанної комунікації вони відчували значні лінгвістичні труднощі.

Крім того, здійснений огляд методичних досліджень 3 викладання дисциплін у ЗВО англійською мовою виявив, що види їхньої професійної діяльності англійською мовою є вельми обмеженими в порівнянні 3 вимогами програм з їхньої основної спеціальності. Так, немає наукових праць, в яких майбутніх політологів навчали би спонтанної дискусії 3 опонентами чи прогнозуванню політичних подій іноземною мовою.

Крім того, специфічною особливістю процесуальної інтеграції є розвиток не лише навчально-професійних іншомовних умінь і іншомовних професійномовленнєвих умінь, але й обов'язкова їх реалізація у виробничому процесі. У цьому випадку - це виступи студентів на міжнародних студентських конференціях англійською мовою, а також у процесі моделювання й реалізації виробничих проектів, ситуацій, написання наукових робіт іноземною мовою.

Нам видається, що виконання таких складних лінгвомовленнєвих дій забезпечується на основі попереднього розвитку відповідних видів компетентностей: професійної й іншомовної мовленнєвої.

Під професійною компетентністю слід розуміти «інтегральну характеристику ділових й особистісних якостей фахівців, що відбиває рівень знань, умінь та навичок, досвіду, достатніх для здійснення певного виду діяльності, що пов’язана із прийняттям рішень».[298]

Ми в даній статті спробуємо розглянути лінгвомовленнєву парадигму дій у процесі навчання майбутніх політологів.

Професійна компетентність майбутніх політологів передбачає здатність вирішувати спеціалізовані завдання у предметній сфері політології та застосовувати ключові теорії та методи політичних досліджень й аналізу 
політики в експертно-аналітичній, політико-організаційній, консультативній, викладацькій та громадській сферах практичної професійної діяльності.

Її складниками $€$ :

- розуміння загальної природи та значення політики як специфічного виду людської діяльності;

- базові знання нормативної та позитивної політичної теорії, політичного аналізу, порівняльної та прикладної політології;

- вільне володіння базовим категоріально-поняттєвим й аналітикодослідницьким апаратом сучасної світової політичної науки; розуміння ключових принципів функціонування і закономірностей розвитку влади та публічної політики, політичних інститутів і процесів, політичної поведінки, політичної культури й ідеології, світової політики і політики окремих країн та регіонів;

- застосування ключових політологічних понять, теорій і методів до аналізу владно-політичних відносин політичних акторів, інститутів й ідей відповідно до певного історичного чи сучасного контексту;

- розуміння базових особливостей реалізації влади в різних політичних системах, їх соціально-економічного, історичного й соціокультурного контексту функціонування і взаємодії;

- здатність використовувати сучасні політологічні теорії, концепти i методи для аналізу політики на місцевому, національному і міжнародному рівнях; здатність конструювати дизайн, розробляти програму й здійснювати політологічні дослідження 3 використанням якісних і кількісних методів й інструментарію прикладного аналізу;

- здатність професійно викладати соціально-політичні дисципліни на відповідному рівні певної освітньої кваліфікації; здатність професійно виконувати політико-організаційні, експертні, консультативні функції на національному і міжнародному ринку праці. 
PEDAGOGY IN MODERN CONDITIONS

Проте для нас важливою $є$ реалізація всіх цих компетентностей англійською мовою в процесі виконання майбутніми політологами їхньої професійної діяльності.

Тоді, за умови успішного забезпечення зазначених компетенцій, іншомовна підготовка закладає міцний фундамент для поступової професіоналізації курсу англійської мови , а стратегічно - забезпечує професійну мобільність. Адже випускнику ЗВО реально доведеться не один раз протягом життя змінювати робоче місце, підвищувати кваліфікацію або проходити перепідготовку.

Таким чином, професійна діяльність майбутнього фахівця, що включає іншомовну компоненту як засіб вирішення професійних завдань і проблем, послідовно моделюється в курсі англійської мови, по-перше, з опорою на етапи формування професійної свідомості на рідній мові i, по-друге, на досягнутий рівень володіння англійською мовою, що дозволяє студентам опановувати не тільки термінологічної системою мови спеціальності, а й отримувати.

На жаль, рівень володіння мовою багатьох викладачів фахових дисциплін не дуже високий, але вони та їхні студенти з часом розробляють стратегії для проведення заняття. Існує поширене припущення, що викладання фахових дисциплін англійською мовою передбачає не тільки переклад навчальних матеріалів курсу з рідної мови на англійську, але також зміну стилю викладання 3 «вчителецентричного», трансляція знань, до більш інтерактивного. Гіпотетично їм (викладачам фахових дисциплін англійською мовою)додатково потрібно знайти альтернативні способи представлення академічного матеріалу студентам, для яких англійська також є другою мовою. У цьому випадку викладачам фахових дисциплін потрібні такі ж уміння, як і викладачам англійської мови. Їм потрібно знати, як змінити подачу матеріалу, переконатися, що їх розуміють, через інтерактивні зміни, які пропонують студенти, та створити атмосферу, де студенти, які працюють нерідною мовою, не бояться говорити; i при цьому потрібно враховувати культурні особливості студентів та їхні потенційно різні рівні володіння мовою. 


\section{PEDAGOGY IN MODERN CONDITIONS}

Проте, в основному, використовують традиційні лекції, які передаються англійською мовою так само, як і рідною. Ми також побачили, що свідомо чи підсвідомо, деякі викладачі фахових дисциплін сучасних провідних ЗВО намагаються ввести більш інтерактивний стиль. Наприклад, на деяких заняттях викладачі фахових дисциплін впроваджували такі підходи:

ведення лекцій у вигляді семінарів, де студенти беруть вільну участь в сесії запитань-відповідей;

сесія запитань-відповідей англійською під час та наприкінці заняття;

* використання наочних предметів та візуальних матеріалів для ілюстрації вивченого;

заняття, під час якого відбулось колективне створення презентації англійською мовою;

* заняття з політології, частина якого проведена у формі прес-конференції (рольова гра);

заняття, побудоване на основі рекламного ролика (3 подальшим використанням презентації PowerPoint) 3 ключовими питаннями для обговорення;

заняття з обліку та аудиту, яке переважно складалося з групової роботи та рольових ігор.

Пристосування до нового стилю в студентів та викладачів викликає певні труднощі:

* студенти соромляться ставити запитання або ж відповідали на запитання викладача рідною мовою;

* студенти можуть мовчати весь час, не розуміючи або мало розуміючи те, що відбувається, не брали участі в роботі;

студенти створюють змістовні слайди PowerPoint, але не можуть чітко їх презентувати;

* викладачі не давали студентам достатньо часу подумати перед тим, як відповідати на складне запитання; не усвідомлювали потребу розвивати в 
PEDAGOGY IN MODERN CONDITIONS

студентах критичне мислення та мислення вищого порядку навіть на магістерських програмах;

* викладачі не дають завдання для виконання під час прослуховування чи перегляду матеріалу, відповідно увага аудиторії не підтримується.

Говорячи про труднощі викладання англійською мовою, на жаль, треба відзначити, що у більшості українських університетах лише невелика кількість викладачів готова викладати свої дисципліни англійською мовою.

Більшість викладачів мають високі освітньо-кваліфікаційні рівні і багато хто здобуває наукові ступені, проте більшість із них професійно віддалені від сучасних тенденцій і мають обмежену підготовку з викладання англійської мови професійного спрямування або не мають іiі взагалі. Тому, для забезпечення теперішніх потреб рівні володіння мовою серед викладачів є достатніми, проте 3 проведенням реформ багатьом викладачам потрібно буде покращувати своє володіння мовою, а для нових викладачів обов’язковою повинна бути відмітка C1. [299]

Існує чітка потреба розробити практичні рекомендації з більш ефективного викладання фахових дисциплін англійською, а також надати викладачам доступ до безкоштовних занять із англійської мови. Це може бути хорошою можливістю співпраці між викладачами англійської мови професійного спрямування та викладачами фахових дисциплін, які мають намір викладати англійською мовою.

Проте більш професійним підходом було би надати можливість та заохотити викладачів фахових дисциплін пройти короткий курс 3 методики викладання фахових дисциплін англійською мовою,як наприклад, п’ятиденний курс Британської Ради «Майстерність викладання фахових дисциплін англійською мовою», який є частиною тренінгової програми у рамках проекту «Англійська мова для університетів».

Вагома роль в сучасному освітньому просторі відводиться в наш час диференційному підходові. Основою його є диференціація тих, хто навчається, за критерієм успішності їх навчання [298]. А. Гоппер вважає, що основними чинниками диференційного підходу до навчання $є$ те, що:не всі студенти 
PEDAGOGY IN MODERN CONDITIONS

оволодівають новими знаннями, формують відповідні уміння, навички в однаковому темпі i 3 однаковою інтенсивністю;кожен студент $\epsilon$ індивідуальністю і має власний темп навчання [301].

Концепція поетапного формування у студентів іншомовної професійної компетенції ( далі ІПК ) базується й на засадах «навчання, сконцентрованого на студентові». Термін «навчання, сконцентроване на студентові» широко вживається у зарубіжній літературі, присвяченій проблемам навчання i викладання [296].

Основними пріоритетами концепції такого навчання є активність студента, що базується на певному досвіді, а також формування у нього певних компетентностей замість накопичення теоретичних знань. Близькими до теорії навчання, сконцентрованого на студентові, $€$ діяльнісний, особистісно орієнтований та індивідуальний підходи [300]. Комплексна концептуальна парадигма поетапного формування IПК майбутніх фахівців нефілологічного профілю у ЗВО зміщує акцент з процесу викладання на процес навчання, а відповідно - з особи викладача на особу студента, 3 діяльності викладача на діяльність студента.

Метою навчання є системотворчий чинник концепції навчання. Так, мета концепції поетапного формування ІПК майбутніх фахівців нефілологічного профілю - формування ІПК студентів на просунутому рівні (B2) - досягається завдяки реалізації компонентів змісту навчання через засвоєння мовного i мовленнєвого матеріалу в наступній послідовності: від розвитку лінгвістичних знань та елементарних мовленнєвих навичок до формування складних інтегрованих умінь, система яких $є$ фундаментальною базою формування i розвитку ІПК у навчальних групах студентів 3 однаковим стартовим рівнем сформованості в них цієї компетентності. Отже, формування ІПК студентів залежить від їх здатності навчатися, здійснюється на основі знань з фонетики, лексикології, граматики, стилістики іноземної мови, фахово-предметних знань, мовленнєвих навичок, умінь та певного практичного комунікативного досвіду, 
відбувається в межах ситуативного контексту, який може бути відтворений в рівних академічних умовах навчання.

Основна організаційна форма навчання у процесі іншомовної професійної підготовки майбутніх фахівців у вітчизняних $3 \mathrm{BO}$ - це практичні заняття (семінарські). Концепція поетапного формування ІПК майбутніх фахівців нефілологічного профілю передбачає проведення навчальних занять у гомогенних групах, сформованих за результатами розвитку ІПК студентів на початковому етапі навчання. Завдяки цьому в процесі групової навчальної діяльності виявляються переваги диференційного підходу до навчання майбутніх фахівців нефілологічного профілю іноземної мови. За навчальний рік рівень сформованості ІКК студентів повинен зрости на одну градацію. Так, якщо рівень сформованості ІКК студентів на момент їх вступу на навчання у ЗВО був рубіжним (B1), то планується, що наприкінці першого року вивчення дисципліни «Іноземна мова» рівень сформованості ІПК студентів повинен зрости до просунутого (B2). Існує можливість переходу студентів на навчання до групи 3 іншим рівнем сформованості ІПК за умови надто швидкого чи сповільненого розвитку в них складових ІПК. [297]

К. Чік порушує питання, чи варто за умови реалізації диференційного підходу організовувати групи за рівнями знань та умінь для вивчення студентами усіх навчальних дисциплін підготовки майбутніх фахівців, вагомих для формування їх професійної компетентності, чи, скажімо, для формування іншомовних комунікативних умінь достатньо організації навчання іноземної мови в групах за рівнями сформованості ІПК студентів.

Висновок. Відтак метою вивчення іноземної мови майбутніми фахівцями нефілологічного профілю має бути не накопичення теоретичних знань, а формування у них практичних навичок усного і писемного мовлення, слухання, розуміння і читання, вміння застосовувати ці навички на практиці.

Підводячи підсумок про викладання фахових дисциплін англійською мовою, зокрема для політологів, говоримо,що теоретичні засади їх підготовки до професійної діяльності англійською мовою полягають у: 


\section{PEDAGOGY IN MODERN CONDITIONS}

1)формуванні професійно діяльнісної та іншомовної мовленнєвої компетентностей на основі процесуальної інтеграції двох різнопланових предметів: політології та англійської мови;

2) їх реалізації в інтегрованому процесі навчання, в якому предмет професійної діяльності $\epsilon$ домінуючим, тоді як англійська мова $\epsilon$ лише допоміжним засобом набуття професійних знань і розвитку на їх основі відповідних умінь;

3) етапами навчання такого інтегрованого процесу є: ознайомлювальний, мовний, навчально-мовленнєвий, мовленнєвий,професійний;

4) професійна діяльність майбутніх політологів у їі англомовному супроводі повинна повною мірою відповідати їхнім реальним професійним потребам, що полягають в об’єктивному висвітленні політичних подій, їх неупередженому аналізі, всебічному обговоренні, ретельному коментуванні та якісному прогнозуванні їхніх наслідків. 


\subsection{2 Паралелі між інноваційними технологіями, педагогікою та лінгвістичними науками}

XXI ст. $є$ епохою Інтернету, який став інформаційним середовищем існування кожної людини. Інформатика та Інтернет нині займає таке важливе місце в житті молодшої частини суспільства, що вчені говорять про формування інтернет-комп'ютерної субкультури. Інтернет на очах перетворюється на комунікативно-інформаційне середовище перебування людини. У мовному аспекті інтернет-комунікація надзвичайно різноманітна й багатогранна, у ній $є$ все, що й у загальнонародній мові. 3 іншого боку, Інтернет має величезний уплив на немережне спілкування в різних його формах.

3 другої половини XX ст. відбувається зближення мовознавства 3 точними науками, зокрема 3 математикою і формується особлива галузь досліджень математична лінгвістика, яка об'єднує математичну формальну теорію граматик і статистичну теорію мови, що використовує методи математичної статистики, теорію інформації. Мовознавство виявилося тією гуманітарною наукою, яка не лише стала використовувати інструментальні методи спостереження (експериментальна фонетика) та інструментальні прийоми (психолінгвістика), але й освоїла математичні способи моделювання мови. [301]

Разом із тим виникає ряд проблем, стосуються змісту, методів, організаційних форм і засобів навчання, обов'язкових рівнів знань різних навчальних предметів, яких має досягнути кожна дитина. [303]

Будь-яка проблематика інформатики, штучного інтелекту, експертних систем, а також будь-якої раціональної людської діяльності стикаються 3 фактами нерозуміння сутності і ролі внеску лінгвістики в комп'ютеризацію 3 боку фахівців технічних наук, а також 3 фактами нерозуміння багатьма мовознавцями провідної ролі комп’ютеризації у перебудові лінгвістичних теорій.

Головною рушійною силою інноваційної діяльності є вчитель, оскільки суб'єктивний чинник $є$ вирішальним і підчас впровадження i поширення нововведень. Педагог-новатор є носієм конкретних нововведень, їх творцем, 
PEDAGOGY IN MODERN CONDITIONS

модифікатором. він має широкі можливості і необмежене поле діяльності, оскільки на практиці переконується в ефективності наявних методик навчання i може корегувати їх, проводити докладну структуризацію досліджень навчальновиховного процесу. [304]

Комп’ютеризація різних видів інтелектуальної діяльності рано чи пізно, але обов'язково обумовить необхідність експлікації мовленнєвої здатності користувача комп'ютера 3 подальшим створенням банків знань і машинних програм у галузі лінгвістики. Гігантські обсяги накопиченої і постійно створюваної інформації, що опрацьовуються за допомогою комп’ютера, все одно мають пройти обробку людиною. Потреба лінгвістичного забезпечення в галузі комп’ютеризації обумовлена створенням людино-машинних систем вирішення інтелектуальних завдань. Необхідно організувати гнучку оперативну взаємодію людини і машини 3 опорою на природну чи штучну мову в певній сфері спілкування. У цьому випадку природна мова служить надійною точкою відліку в створенні комп’ютерних систем, тому що творці й користувачі говорять, пишуть і думають переважно природною мовою. Урахування цього фактору допоможе в розв’язанні деяких проблем комп’ютеризації.

Комп'ютерна лінгвістика є одним 3 актуальних науково-практичних напрямків інформаційної технології сучасного мовознавства. 3 кінця ХХ ст. кількість електронних текстів і документів, які існують лише у комп’ютерному варіанті, надзвичайно виросла і це зумовило необхідність створення технологій, що пов'язані з обробкою даних. Обробка документів, створених на матеріалі природних мов - це нові технології, які допомагають людині використовувати електронні тексти і легко знаходити та опрацьовувати документи. Наприклад, така процедура, як резюмування тексту дозволяє зменшити його обсяг и зробити можливим показ навіть на невеликому екрані (планшети, мобільні телефони).

Завданням комп’ютерної лінгвістики спочатку було створення складних систем обслуговування комп'ютерів за допомогою мови, які роблять можливим безпосереднє спілкування людини 3 комп’ютером, автоматичну переробку, запам’ятовування, пошук і подачу інформації засобами мови. При цьому багато 


\section{PEDAGOGY IN MODERN CONDITIONS}

традиційних галузей мовознавства суттєво змінюють методику дослідження завдяки можливості побудови програм, що реконструюють альтернативні варіанти фонологічних і граматичних систем прамов; машинному визначенню часу розпаду споріднених мов за допомогою лексикостатистики; укладання машинних словників для величезних обсягів давніх писемних текстів; здійсненню допоміжних операцій для дешифрування давніх систем письма тощо.

Однією з найважливіших проблем комп’ютерної лінгвістики є моделювання природної мови. Прикладні моделі вирізняються певним спрощенням мовної реальності, хоча це не завжди означає ігнорування реальної складності модельованого об'єкта. Дослідники намагаються не обходити увагою багатоаспектність, багатолінійність, відкритість мовного механізму, але у новій дослідницькій парадигмі це не завжди можна реально враховувати й реалізовувати. Багато принципових моментів організації природних мов взагалі не вписуються в систему конкретних однозначних досліджень, вибудуваних на засадах точних наук: це нечіткість, невиразність і дифузність значень мовних одиниць, динамічність мовної системи, образність номінації (насамперед метафоричність), не співмірність обсягів словника й позначуваної ним інформації, величезні потенції в освоєнні нових знань, різноманітність функцій мови у суспільстві.

Розвиток лінгвістичних досліджень останніх десятиліть характеризується міждисциплінарною взаємодією з іншими науками (кібернетика, інформатика, семіотика, соціологія, психологія тощо). Інтегрованість зусиль учених зумовила розвиток таких комплексних наук, як соціолінгвістика, психолінгвістика, нейролінгвістика, когнітивна лінгвістика, математична лінгвістика, кібернетична лінгвістика, комп'ютерна лінгвістика тощо.

Кожну 3 цих наук доцільно розглядати як окремий напрям прикладної лінгвістики, який здатен дати суттєвий поштовх розвитку новітніх технологій, науково-технічному прогресу в цілому. Особлива роль у цьому відводиться саме комп'ютерній лінгвістиці, яка охоплює питання автоматичного (машинного) 
перекладу, лінгвістичного забезпечення інтелектуальних систем, створення інформаційних мов, автоматичного анотування та індексування документів, автоматичного аналізу (розпізнавання) й автоматичного синтезу тексту, комп'ютеризації навчання тощо. Перелічені аспекти комп'ютерної лінгвістики мають безпосереднє відношення до проблем штучного інтелекту, розв'язання яких потребує комплексних зусиль дослідників різних наук [305].

Серед напрямів прикладної лінгвістики $є$ й документознавство. Саме документ є втіленням лінгвістичного забезпечення людської комунікації, що полягає в обробці, зберіганні, передачі соціально значимої інформації, зафіксованої в текстах. Названі основні напрями досліджень у межах сучасної прикладної лінгвістики не становлять собою закритого списку, адже життя процес динамічний, і розвиток науково-технічного прогресу виявляє і ще обов'язково виявить нові сфери практичного застосування мови. Однак i дослідження названих прикладних аспектів мови має дуже багатогранні i багатообіцяючі перспективи, особливо в Україні.

Прикладна лінгвістика - напрям у мовознавстві, що займається розробкою методів вирішення практичних завдань, пов'язаних з використанням мови. Прикладні сфери мовознавства здавна відрізнялися широкою різноманітністю. Найбільш древні з них - лист (графіка), методика навчання рідної та нерідної мов, лексикографія. Надалі з'явилися переклад, дешифрування, орфографія, термінознавство. Один 3 традиційних напрямів прикладної лінгвістики пов'язаний з участю в мовній політиці держави і формується як мовна політика i мовне будівництво. Одночасно 3 розвитком і вдосконаленням класичних областей прикладного мовознавства в другій половині XX в. намітився i визначився ряд нових його напрямків, які представляють собою логічне продовження історичного розвитку прикладної лінгвістики на новому етапі, обумовленому сучасною науково-технічною революцією, зміцненням взаємозв'язку суспільних, природних і технічних наук. До цих напрямків належать: обробка інформації, моделювання знань, автоматична обробка мови в іiі письмовій та усній формах. 
Найважливішим завданням вищої освіти в Україні на сучасному етапі $є$ підготовка висококваліфікованих, конкурентоспроможних фахівців, що забезпечуватимуть нагальні потреби вітчизняного ринку праці. Значення напряму прикладна лінгвістика в сучасному суспільстві важко переоцінити, тому що мова $є$ найважливішим засобом комунікації в суспільстві і тісно пов'язана 3 мисленням і свідомістю. Технологізація суспільства, розширення функцій мови в ньому, поява нових можливостей застосування знань про мову в нелінгвістичних дисциплінах та різних сферах діяльності людини зумовлюють посилення уваги до фахової підготовки майбутніх фахівців у галузі прикладної лінгвістики.

На сьогодні розроблено значну кількість програмних засобів, що дозволяють розв'язати за допомогою комп'ютера досить широке коло різних задач і різної складності. [303]

В останні десятиріччя, коли мовознавство та інші науки набули антропоцентричної спрямованості, найбільш актуальними стали питання, пов'язані з моделюванням штучного інтелекту, процедурами вербального кодування та декодування інформації і реалізацією регулятивної функції мови; мовленнєвого впливу та мовленнєвої діагностики. Необхідним стало дослідити засоби мовленнєвого трансформування світу (прикладні можливості когнітивної лінгвістики, психолінгвістики), мовленнєвого впливу (практичне застосування теорії і практики вербальної комунікації, сугестивної лінгвістики), поставити на відповідний науковий рівень мовленнєву діагностику, підвищити ефективність мовної політики, розробити відповідні методи парламентської лінгвістики, тобто тих галузей знання, що сформувалися на межі лінгвістики, семіотики, психології, соціології, інформатики та когнітології. У XX столітті серед прикладних проблем мовознавства на перший план вийшли завдання автоматичної обробки усних та письмових текстів, упровадження математичних методів у дослідження й опис мовних процесів.

Ці тенденції свідчать, що головною функцією освіти є розвиток людини. Освіта має забезпечити кожному, хто навчається, широкі можливості для 


\section{PEDAGOGY IN MODERN CONDITIONS}

здобуття нових знань та навичок. Докорінна зміна традиційного способу життя породжує нові вимоги, які спонукають людину краще розуміти інших і світ загалом. Інноваційність розглядається не тільки, як налаштованість на сприйняття, продукування і застосування нового, а насамперед як відкритість. Вона забезпечує умови розвитку особистості, здійснення iї прав на іiі індивідуальний творчий внесок, на особистісну ініціативу, на свободу саморозвитку. 


\subsection{3 Педагогічні умови та методи вдосконалення диригентсько-хорової підготовки магістрів мистецьких спеціалізацій}

Процес вдосконалення диригентсько-хорової підготовки магістрів мистецьких спеціалізацій буде найбільш ефективним при виявленні індивідуальних якостей студента в освітньому процесі. Діяльність такого роду здійсненна лише в особливому педагогічному середовищі, завдяки вільному обміну думками, ідеями, особистісному підключенні студента й педагога в навчально-виховну взаємодію. При формулюванні педагогічних умов вдосконалення фахової підготовки магістрів ми керувалися принципом єдності змістового й процесуального аспектів під час знаходження оптимальних рішень поставленої проблеми, а також знаннями об'єктивних i суб'єктивних закономірностей функціонування особистісної ситуації, що $є$ в нашому процесі засобом підвищення рівня означеної підготовки.

Виходячи з цього, нами були виокремлені наступні педагогічні умови:

- організація діалогової взаємодії у навчально-виховному процесі;

- забезпечення психологічного комфорту студента на заняттях 3 диригентсько-хорових дисциплін;

- диференційований підхід до особистості магістра, її корекції в умовах навчання у ВН3;

- створення можливостей для художньо-творчої самореалізації, самовдосконалення, саморозвитку в процесі означеної підготовки.

Аргументуємо ці положення. Організачія діалогової взаємодії у навчальновиховному процесі $\epsilon$, на наш погляд, важливою умовою вдосконалення диригентсько-хорової підготовки магістрів, адже стимулювання особистісного функціонування студента в ході навчання можливе лише в тому випадку, якщо він буде поставлений у позицію рівноправного суб'єкта даного процесу. Багато досліджень психології, педагогіки саме з діалогом пов'язують успіх у навчанні та вихованні. Найбагатший матеріал про діалогічне спілкування ми знаходимо у працях таких учених, як В. Андрєєв [304] (про педагогічну евристику), 
С. Бєгідова [305] (у концепції особистісно орієнтованої освіти), В. Біблер [306] (про Школу діалогу культур), А. Вербицький [307] (про контекстне навчання), Ще раніше важливі положення діалогічного навчання ми знаходимо в педагогіці Дж. Дьюї [308], у теорії К. Роджерса і його послідовників [309].

Навчання як процес взаємодії педагога й студента відбувається на основі певного навчального змісту. У нашому питанні такою квінтесенцією $\epsilon$ диригентсько-хорова підготовка і процес іiі педагогічного аналізу. Принцип діалогічної взаємодії, запропонований нами, дозволить відмовитися від традиційної дихотомії: педагог-студент, коли потреба у ініціативному спеціалісті 3 активним професійно-творчим мисленням супроводжується незадоволенням освітнім процесом, а саме: не приділяється належної уваги особистісному розвитку студентів-магістрів, нерозвинута їх самостійність, на низькому рівні перебуває мотиваційна готовність до формування та прояву творчого потенціалу. Як показує практика, ініціативному студенту потрібні не тільки глибокі знання в галузі педагогіки, психології, музичного мистецтва, але й певні особистісні якості, спеціалізовані вміння, що сприятимуть активізації та формуванню високої мотиваційної готовності до майбутньої професійної діяльності.

Таким чином, організація діалогічної взаємодії на заняттях 3 дисциплін диригентсько-хорового циклу дозволить, на наш погляд, так побудувати процес навчання, щоб забезпечити можливість кожному магістру реалізувати свій творчий потенціал, пізнати своє внутрішнє «Я». Отже, створити можливість для прояву особистісних якостей. В результаті у музично-педагогічному процесі виникне певний комунікативний ланцюг: композитор - хоровий твір - педагог студент - співпереживання - співтворчість. Принцип діалогічної взаємодії, відкриваючи всі комунікаційні канали, забезпечить постійний стимул до саморозвитку, дозволить інтегрувати процес особистісного розвитку студента, стимулювати прояв суб’єктивних якостей (оцінювання, осмислювання, рефлексію). 
PEDAGOGY IN MODERN CONDITIONS

Наступна педагогічна умова стосується забезпечення психологічного комфорту для студента на заняттях з диригентсько-хорових дисииплін. На наш погляд, вона є важливим фактором самовдосконалення особистої діяльності магістрів. Принцип психологічного комфорту означає, що навчальний процес повинен бути організований і проведений так, щоб забезпечити мотивацію навчання й позитивне емоційне відношення до нього [310]. Такий стан досягається шляхом зняття всіляких психологічних бар'єрів, створення безконфліктного середовища, у якій кожен себе почував би комфортно; атмосфери, що виключає виникнення почуття остраху за невдале слово або дію. В особистісній ситуації студент відчуває «емоційне благополуччя» [310], впевненість у собі, можливість піднятися на вищий рівень підготовки, реалізує вроджену в собі від природи потребу в схваленні. При цьому мова йде не про прийняття педагогом думки, поділу точки зору, а прийнятті особистості студента як унікальної даності, як носія своїх цінностей [310].

Виходячи з цього, ми пропонуємо звернути увагу з боку викладачів на здійснення опори на самоконтроль, самооцінку, самоаналіз, саморегуляцію студентів, їх рефлексивні здібності; диференційований творчий підхід до кожного студента; динамічний характер, гнучкість змісту програм з предметів диригентсько-хорового циклу, їх поступове вдосконалення 3 урахуванням особистісних здібностей студентів та диференціації навчання; створення психологічного комфорту на індивідуальних заняттях за умов досягнень чи невдач студентів, доброзичливе ставлення до них з боку викладачів; атмосфери повної творчої свободи, ініціативи з опорою на рефлексивні здібності майбутніх фахівців; у повному обсязі здійснення навчально-методичної забезпеченості процесу диригентсько-хорової підготовки магістрів. Впроваджуючи ці дії в означений процес, ми припускаємо, що вони повинні забезпечити розвиток творчої мотивації, стимулювати чітко виражений особистісний прояв у професійно-педагогічній діяльності, тим самим витісняючи індиферентні, егоїстичні, репродуктивні підходи до навчальної роботи. 
PEDAGOGY IN MODERN CONDITIONS

Зауважимо, що психологічний комфорт студента забезпечується також методом безоцінювання, що має на увазі створення обставин, за яких відсутнє зовнішнє міркування. Переконання з боку педагога щодо власної системи цінностей нерідко сприймається студентом як погроза й приводить до захисної реакції. Але якщо судження на підставі загальних мірок відсутні, то студент стає більш відкритий своєму досвіду й починає шукати джерело оцінювання усередині себе.

Таким чином, потрібен певний стиль педагогічного спілкування, що спрямований на «встановлення відносин співробітництва спочатку через «підстроювання» до партнера по спілкуванню, безкорисливо-альтруїстичне зосередження на ньому й потім висхідна до його безоцінювального прийняття, визнання принципової рівності особистісних позицій педагога й студента, їхньої рівноцінності в довірчому діалозі й спільній творчості» [310]. Іншими словами, рівноправна взаємодія, прийняття, безоцінювання, емпатійність і $є$ та психологічна основа, що сприяє формуванню сфери відносин особистості, що в свою чергу, є об’єктивною умовою для реалізації особистісного підходу при засвоєнні предметів диригентсько-хорового циклу.

Диферениійований підхід до особистості магістра, ї̈ корекиії в умовах навчання у ВНЗ. Для успішного формування зазначеної умови однаковою мірою важливо постійно актуалізувати як емоційну чуйність студентів, так і їхнй інтелектуальний потенціал, тобто домагатися гармонії почуттєвого, раціонального й розумового розвитку особистості. Аналіз хорового твору (музична герменевтика) - це альфа й омега професійної музично-педагогічної діяльності. Ми припустили, що використання принципів і методів музичного аналізу в ході вивчення хорового репертуару на заняттях 3 диригування, хорового класу й буде сприяти стимулюванню інтелектуальної й емоційновольової сфер особистості студента, його особистісних функцій, що приведе до покращення його суб’єктивного ставлення до своєї фахової підготовки зокрема. Він є активним, тому що здійснюється в ході розширення й збагачення духовноособистісного, музично-слухового й професійно-творчого досвіду особистості 
магістра. До того ж, процес освоєння припускає діалог-спілкування 3 твором хорового мистецтва, міркування про нього, висловлювання своєї думки, оцінки, ставлення, усвідомлення його образного змісту тощо.

Виходячи із цього, ми пропонуємо наступні методи, що, на нашу думку, допоможуть у вдосконаленні диригентсько-хорової підготовки магістрів мистецьких спеціалізацій та можуть бути застосовані у виконавських класах, зокрема, на заняттях 3 диригування:

1. Метод інтонаційно-виконавського аналізу. Він містить комплексний підхід до вивчення хорового твору, спрямований на розкриття ідейно-образного змісту, осягнення його цілісної форми й на цій основі - створення студентом власного бачення (певного диригентського-жесту).

Таким чином, кінцевою метою інтонаційно-виконавського аналізу $є$ осягнення інтонаційно-фабульної форми й створення на цій основі власного розуміння студентом даної сторони хорового твору.

2. Метод художніх асоизіацій (художнього пізнання) - один із ефективних способів розвитку й формування пізнавальної сфери особистості студента. Цей метод спирається на комунікативну функцію музично-хорового мистецтва. Він спрямований на вербалізацію думок, почуттів, переживань, що виникли в процесі пізнання студентом твору. Особливість даного методу, на нашу думку, полягає в тому, що міркування-діалог студента й педагога ведеться завдяки тому або іншому хоровому твору, де студент корегує свої вже сформовані професійні установки, рефлексує своє бачення твору, пов'язує набуті знання з майбутньою фаховою діяльністю.

Таким чином, запропоновані методи, що спрямовані на суб’єктивне осягнення змісту хорового твору, допоможуть у здійснюванні диференційованого підходу до особистісних якостей магістрів, їх корекції в умовах подальшої професійної діяльності.

Четверта педагогічна умова базується на створенні можливостей для художньо-творчої самореалізації, самовдосконалення, саморозвитку в процесі означеної підготовки. Ми вважаємо, що художньо-творча самореалізація 


\section{PEDAGOGY IN MODERN CONDITIONS}

можлива за умов використання запропонованого нами методу індивідуальних навчально-дослідних завдань (ІНД3) проблемного характеру.

ІНДЗ - є творчим видом позааудиторної самостійної роботи студентів навчального, навчально-дослідного чи проектно-конструкторського характеру, яке використовується у процесі вивчення програмного матеріалу предметів диригентсько-хорового циклу й завершується разом зі складанням підсумкового іспиту чи заліку з окремої навчальної дисципліни. Завдання виконуються в процесі бесіди, дискусії й мають, як правило, форму «питання-відповідь» або діалогічний принцип побудови.

Стосовно нашої проблематики ми виокремлюємо наступні методи:

•метод конструктивного діалогу, який допоможе знайти вихід із проблемних ситуацій у процесі оптимального вибору теми й рішення ІНДЗ 3 предметів хорознавства та диригування;

•метод аналізу-порівняння, уточнення особистісних уявлень педагога й студента на заняттях з хорового класу;

•метод евристичних питань, які необхідні студенту для пошуку додаткової інформації при рішенні ІНДЗ з предмету «Практикум роботи з хором»;

•метод інверсї̈ полягає в процесі протиставлення нових та традиційних підходів до вирішення ІНДЗ;

•метод метафор, який допомагатиме образному висловлюванню думок й почуттів у процесі сприйняття хорового твору, що активізують змістовопошукову творчу активність та самостійну роботу магістрів.

Після того, як нами були визначені «вузькі місця» в традиційно діючій системі навчання магістрів і виокремлені методи й умови щодо вдосконалення диригентсько-хорової підготовки, розпочалася робота розробки індивідуального технологічного підходу щодо реалізації на практиці особистісно орієнтованих технологій навчання в ході підготовки магістрів мистецьких спеціалізацій.

Таким чином, ми спробували практично довести, що на сьогодні стає очевидним важливість питання вдосконалення системи музично-педагогічної освіти i, зокрема, диригентсько-хорової підготовки магістрів та застосування в 


\section{PEDAGOGY IN MODERN CONDITIONS}

ній особистісного підходу, який, у значній мірі, визначає всю структуру праці викладача. 3 означеного зрозуміло, що все більше в ній переважають інноваційні підходи. Але новітні технології не можуть розвиватися самі по собі, вони повинні стати органічною частиною всього науково-обгрунтованого навчального процесу вищої школи. Насамперед, первинною має бути досконала практична діяльність педагога-музиканта, його індивідуальний та творчий досвід, що приведе до розвитку внутрішнього індивідуально-творчого потенціалу особистості магістрів мистецьких спеціалізацій. 
PEDAGOGY IN MODERN CONDITIONS

\section{REFERENCES:}

1. Galuzinsky VM, Eunuch MB Pedagogy: theory and history: a textbook. Kyiv: Higher school. 1995. 35 p.

2. Volkova NP Pedagogy: a textbook for universities. Kyiv: Academy, 2001. 22 p.

3. Kan-Kalik VA Teacher in pedagogical communication: a book for teachers. Moscow: Enlightenment, 1987. 190 p.

4. Konoryukova IV Psychological barriers in pedagogical communication. Personality, family and society. Questions of pedagogy and psychology: materials of the XLII international scientific-practical conference. Novosibirsk: SIBAK, № 7 (42), 2014. Pp .12-16.

5. Kunitsyna VN Interpersonal communication: a textbook for universities. SPb.: Piter, $2001.544 \mathrm{p}$.

6. Leontiev AA Pedagogical communication. Moscow: Knowledge, 1979. 48 p.

7. Petrovskyi, Arthur. Social psychology. Moscow: Prosvescheniye, 1978.

8. Ternopilska, Valentina. System of instilling social and communicative culture of pupils of a secondary school in extracurricular activities. (Dissertation for a Doctor of Pedagogical Sciences), Institute for Educational Problems of National Academy of Pedagogical Sciences of Ukraine, Kyiv, 2009.

9. Zaniuk, Svitlana. Psychology of motivation: manual. Kyiv: Lybid, 2002.

10. Zhyrun, Oleg. Moral consciousness in professional development. Bulletin of the National Technical University of Ukraine "Kyiv Polytechnic Institute". Philosophy. Psychology. Pedagogics, 1, 2011: 109-112.

11.Andreev A.A., Soldatkin VI Distance learning: essence, technology, organization. M .: Publishing house MESI, 1999.S. 196.

12. Wikipedia. URL: http://ru.wikipedia.org/ wiki. (date of access: 02.06.2009).

13. Volkova A.N. Specificity of language distance learning // Foreign languages in higher education: problems, experience, prospects: materials of an interuniversity scientific and methodological seminar. Chita. March 13, 2001 Chita: ZIP Sib UPK, 2001.S. 30 - 35. 
PEDAGOGY IN MODERN CONDITIONS

14. Glossary. URL: http://www.glossary.ru/ cgi-bin / gl_sch2.cgi? ROhwgnuigtol (date accessed: 08.06.2009).

15. Elashkina N.V. Independent cognitive activity of a student in distance learning foreign languages // Philology. History. Intercultural communication, abstracts of the regional conferences of young scientists (Irkutsk, February 26, 2003). Irkutsk: IGLU, 2003.S. 33 - 34.

16. Zubov A. V., Zubova I. I. Information technologies in linguistics: textbook. manual for stud. lingual. fact-tov higher. study. institutions. M .: Publishing Center "Academy", 2004. P. 208.

17. Bazhylchuk O.V. Theoretical and methodological principles of professional training of future specialists in physical therapy, occupational therapy to work on restoring the health of athletes: author's ref. dis. ... to Dr. ped. sciences: 13.00.04 Theory and methods of vocational education. Khmelnytsky, 2019. 43 p.

18. Belcheva T.F., Elkin M.V., Golovkova M.M., Korobchenko A.A. Fundamentals of scientific and pedagogical research: a textbook. Kharkiv: Print House printing house, 2019. $217 \mathrm{p}$.

19. Boychuk T.V., Lewandowski O.S. Actual problems of professional training of physical rehabilitation specialists / Proceedings of the scientific-practical conference «Physical and physiotherapeutic rehabilitation. Rehabilitation SPA-technologies» (April 29-30, Sevastopol, 2009p.). Sevastopol, 2009. P. 11-12.

20. Chugaevsky VG Socializing functions of higher education in the context of European integration /International Scientific Forum: Sociology, Psychology, Pedagogy, Management: Coll. Science. Kyiv Avenue: NPU Publishing House. M.P. Dragomanova, 2013. Vip. 12. P. 110-118.

21. Chuvatova N.E. Pedagogical values as a basis of professionalism of the teacher's personality: author's ref. dis. ... Cand. ped. Science: special. 13.00.01 General pedagogy, history of pedagogy and education. Saransk, 2007. 19 p.

22. Kazakova S.M., Kazakov E.A. The current state of training and prospects for employment of specialists in physical rehabilitation/Proceedings of the scientific- 
PEDAGOGY IN MODERN CONDITIONS

practical conference «Physical and physiotherapeutic rehabilitation. Rehabilitation of SPA technologies» (April 29-30, Sevastopol, 2009p.). Sevastopol, 2009. P. 36-37.

23. Lyannoy Yu.O. Theoretical and methodical bases of professional training of future masters on physical rehabilitation in higher educational institutions: dis. ... to Dr. ped. Sciences: 13.00.04 Theory and methods of vocational education. Kyiv, 2017. $674 \mathrm{p}$.

24. Patton N., Higgs J. and Smith M. Using theories of learning in workplaces to enhance physiotherapy clinical education /Physiotherapy: Theory and Practice. 2013. Vol. 29. Issue 7. January. P. 493-503.

25. Bartosik P. Edukacja domowa a szkolnictwo publiczne - spór o edukacyjną wolność (2009). Gazeta szkolna. - 23/24 (453/454). - S. 1-8.

26. Домашнє навчання. Матеріал з Вікіпедії - вільної енциклопедії (2017). URL: https://uk.wikipedia.org/wiki/Домашнє_навчання

27. Вихрестенко Ж. Домашня (сімейна) освіта як альтернативна форма загальної середньої освіти (2015). Народна освіта. Електронне наукове фахове видання, 1(25). URL: https://www.narodnaosvita.kiev.ua/?page_id=2756

28. Гончаренко С. Український педагогічний словник (1997). К.: Либідь, 376 c.

29. Webster's Encyclopedic Unabridged Dictionary (1996). New York, 2256 p.

30. Сльникова О. Домашне навчання як альтернативна форма загальної середньої освіти (2015). Освітня політика. Портал громадських експертів. URL: http://education-ua.org/ru/articles/361-domashne-navchannya-yak-alternativnaforma-zagalnoji-serednoji-osviti

31. Загитова А. Преимущества и недостатки домашнего семейного обучения (2017). Материалы IX Международной научной конференции «Студенческий научный форум 2017». URL: https://scienceforum.ru/2017/article/2017033376

32. Соціально-психологічні засади становлення екологічно орієнтованого способу життя особистості (2015). Монографія: за ред. Ю.М. Швалба. - К.: Педагогічна думка, 216 с. 
PEDAGOGY IN MODERN CONDITIONS

33. Про освіту. Закон України (2017). Відомості Верховної Ради, 38-39. URL: https://zakon.rada.gov.ua/laws/show/2145-19\#Text

34. Антуфьева, М. П. Актуальные вопросы семейного образования: понятие, причины, подходы, проблемы (2018). Молодой ученый. - 15 (201). - С. 204-206. URL: https://moluch.ru/archive/201/49371/

35. Берлинська декларація, прийнята на I Всесвітній конференції з домашньої освіти (2012). Global Home Education Conference. Берлін.

36. Енциклопедичний словник Брокгауза і Ефрона в 83 тт. і 4 додат. (2001). M.: Teppa.

37. Кощиенко И.В., Покровская Л.И. Семейное образование как вариативная форма обучения (2015). Проблемы педагогики и психологии. 4. - С. 187-193.

38. Стародубцева И.А. Психолого-педагогические основы проектирования и организации семейного образования (2008). Дис. на соиск. ученой степени канд. пед. наук 13.00.01 - общая педагогика, история педагогики и образования, Сургутский государственный педагогический университет.

39. Якунина А.Н. Педагогические условия становления семейного образования в России: культурно-исторический подход (2014): Дис.на соиск. ученой степени канд.псих.наук.

40. Brian Ray D. Worldwide guide to homeschooling: facts and stats on the benefits of home school (2002). Nashville : Tennessee, -213 p.

41. Рубан Л. Сучасні тенденції поширення ідей про домашню освіту (2015). Педагогічні науки: теорія, історія, інноваційні технології. - №4 (48). - С. 118-125.

42. Сайт Сімейної освіти. URL: http://semeynoe.com/tag/беларусь/

43. Stevens M. L. Kingdom of children: culture and controversy in the homeschooling movement (2001). - Princeton University Press. - 228 p.

44. Holt J. Homeschooling lets a child's mind grow (1083). The USA Today.- Dec. 14. - P. 4.

45. Питер Грей. Свобода учиться. Игра против школы (2016). М.: Манн, Иванов и Фербер. - 336 с. 
PEDAGOGY IN MODERN CONDITIONS

46. Домашня освіта: світовий досвід. Слово вчителю : християнський духовно-просвітницький часопис.

URL: http://slovovchitelyu.org/journal/nom26/domashnya-osvita

47. Каменєва Т. Хоумскулінг та онлайн-навчання: короткострокова необхідність чи приваблива перспектива? (2020). Громадська думка про

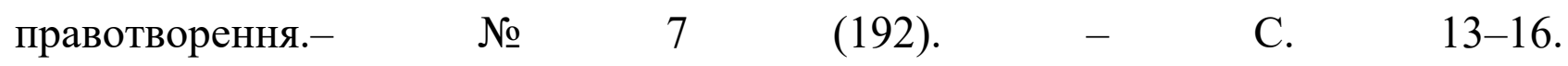
URL: http://nbuviap.gov.ua/images/dumka/2020/7.pdf. - Назва з екрана

48. Ситник М. Почему украинцы массово переходят на домашнее образование? URL: https://www.dsnews.ua/society/houmskuling-neobhodimostkotoraya-mozhet-stat-trendom-11092019220000

49. Home School Legal Defense Association - URL: http://www.hslda.org/

50. Герасимова Н. А. Интегральная технология обучения в физкультурном образовании школьников : дис...канд. пед. наук. СПб., 2003. 251 с.

51. Долбишева Н. Г. Теоретико-методичні основи формування знань про фізичне здоров'я в системі фізичного виховання у старшокласників : автореф. дис... канд. наук з фіз. виховання і спорту. Нац. ун-т фіз. виховання і спорту України. К., 2006. 21 с.

52. Оліяр М. П. Теоретико-методичні засади формування комунікативностратегічної компетентності майбутніх учителів початкових класів. Дис. ... докт. пед. наук. Одеса. 2016. 577 с.

53. Сисоєва С. О. Освіта і особистість в умовах постіндустріального світу: монографія. Хмельницький: ХГПА, 2008. 324 с.

54. Габа I. М. Експертиза як спосіб оцінки інноваційного потенціалу освітнього середовища ВНЗ. Актуальні проблеми психології. 2014. Т. 7. Вип. 36. C. $121-131$.

55. Абрамович С., Тілло М., Чікарькова М. Культурологія : навчальний посібник / Київський нац. торговельно-екон. ун-т, Чернівецький торговельноекон. ін-т. К.: Кондор, 2005. 347 с.

56. Професійно-педагогічна підготовка майбутнього вчителя початкового загальноосвітнього навчального закладу в умовах Нової української школи. 
PEDAGOGY IN MODERN CONDITIONS

С.Ф.Одайник, Л.С.Петухова, Є.О.Співаковська, Б.М.Андрієвський,

О.М.Пинзеник, Л.А.Пермінова, Т.І.Молнар, В.В.Ляпіна, І.В.Воронюк, Н.В.Кабельнікова): Монографічна збірка / за ред. Л.А.Пермінової. Ч. 1. Херсон: «Айлант», 2018. 158 с.

57. Армейська Л. В. Інноваційні підходи до організаційно-методичного супроводу навчального процесу на факультеті підвищення кваліфікації педагогічних працівників/ Л. В. Армейська // Імідж сучасного педагога. - №10 (129), 2012.- C. 16-18

58. Базовий компонент дошкільної освіти / Науковий керівник: А. М. Богуш, дійсний член НАПН України, проф, д-р пед. наук; Авт. кол-в: Богуш А. М., Бєлєнька Г. В., Богініч О. Л., Гавриш Н. В., Долинна О. П., Ільченко Т. С., Коваленко О. В., Лисенко Г. М., Машовець М. А., Низковська О. В., Панасюк Т. В., Піроженко Т. О., Поніманська Т. І., Сідєльнікова О. Д., Шевчук А. С., Якименко Л. Ю. - К. : Видавництво, 2012. - 26 с.

59. Концепція національного виховання // Освіта. - 1994. - 26 жовт. - С. 5 12.

60. Масол Л. Школа культури виховує людину, яка мислить і прагне творити / Л. Масол // Початкова шк. - 2001. - № 5. - С. 38-39.

61. Миропольська Н. С. Формувати почуття прекрасного / Н. Є. Миропольська. - К.: Знання, 1987. - 32 с. -(Сер. 7 «Педагогічна» ; 13). - Бібліогр. :c. 32 .

62. Отич О. М. Мистецтво у розвитку творчої індивідуальності майбутнього педагога професійного навчання: комплекс навч.-метод. забезпечення викладання психолого-педагогічних дисциплін: у 3 ч. / О. М. Отич ; АПН України, Ін-т пед. і психології проф. освіти АПН України. - Полтава: ІнтерГрафіка, 2006.- Ч. I : Навчальні плани та програми з дисциплін психологопедагогічного циклу. - 2006. - 168 с.

63. Руденко В. Н. Культурологические основания целостности содержания высшего образования / В. Н. Руденко // Педагогика. - 2004. - № 1. - С. 42- 48. 
PEDAGOGY IN MODERN CONDITIONS

64. Рудницька О. Культуровідповідність мистецької освіти / О. Рудницька // Неперервна професійна освіта : проблеми, пошуки, перспективи : монограф. зб. ст. - К., 2000. - C. 108-133.

65. Растригіна А.М. Субъектность как необходимое условие профессионально-личностного развития будущего педагога. - Subjectiveness as the necessary condition of professional and individual development of a future teacher // The spread of spirituality in the reality of artistic education - Vilnius, Литва -20080,5 д.а.

66. Растригіна А.М. Компетентнісний підхід до підготовки майбутнього магістра музичного мистецтва //Сучасні стратегії університетської освіти: якісний вимір: матер. Міжнар.наук-практ.конференц - К.:Київський ун-т ім. Б.Грінченка, 2012 - С.501-509

67. Растригіна А.М. Віват, магістри! : навчально-методичний посібник для студентів педагогічних університетів. - Кіровоград, 2018 -164 с.

68. Артбізнес і народне мистецтво. Народна творчість та етнографія, 1994. № 5-6. C. 22

69. Гуманізуючий потенціал новітніх інформаційних технологій в освіті: Монографія/ І. Ф. Аршава, Е. Л. Носенко, М. А. Салюк. Д.: Акцент ПП, 2013. $172 \mathrm{c}$.

70. Ейвас Л. Ф. 3 досвіду підготовки вчителя декоративно-прикладного мистецтва в Україні : монографія. Кривий Ріг : Видавець ФО-П Чернявський Д.О., 2016. 136c.

71. Короткий тлумачний словник української мови: Близько 6750 слів /Під ред. Д.Г.Гринчишина. - 2-ге вид.; перероб. І допов. К.: Радник, 1988. С. 263.

72. Кот М. Вишивка Дрогобиччини: традиції і сучасність. Львів: Інститут народознавства НАН України, 1999. 107 с.

73. Савка Л.В. Вчитель вчителів. Трудова підготовка в закладах освіти. 1998. №4. C. 45-46.

74. Савка Л.В. Методика вивчення «Української народної вишивки» майбутніми вчителями обслуговуючої праці: автореф. дис. на здобуття наук. 
ступеня канд.пед.наук: спец. 13.00.02 - теорія та методика трудового навчання. K., 2001. 20 c.

75. Хохліна О.П. Проблема методологічних принципів психології. Юридична психологія, № 2, 2015. С.5-25.

76. Чумарна М.І. Код української вишивки. Львів: Апріорі, 2008. 192 с.

77. Мудрак О.В. Проблеми і шляхи розвитку екологічної освіти в Україні / О.В. Мудрак // Людини і довкілля. Проблеми неоекології. 2002. Вип. 3. - Харків: XНУ, 2002. - C. $14-18$.

78. http://archive.mama-86.org/archive/ecodemocracy/skyba_u.htm

79. Орлянська В.В., Самохвалова А.І. Вдосконалення екологічно освіти в технічних вищих навчальних закладах / Матеріали XI-ї наукової інтернетконференції студентів, аспірантів і молодих вчених Національного юридичного університету імені Ярослава Мудрого «Безпека людини і реалізація права на працю в сучасних умовах життєдіяльності», 23 - 24 квітня 2020 р. - Х.: Нац. юрид. ун-т, 2020. - С $345-348$.

80. Самохвалова А.І., Онищенко Н.Г. Специфіка викладання екологічних дисциплін у технічних вищих навчальних закладах / Травневі наукові читання: XXX Міжнародна науково-практична інтернет-конференція: тези доповідей, Луцьк, 12 травня 2020 р. - Ч. 4. - Дніпро: ГО «НОК», 2020. - С.18 - 21.

81. Василенко А.О., Туркот Т.І. Вища екологічна освіта в Україні та Центральноазійському регіоні: порівняльний аналіз. URL: file://C:/Users/Anna/Downloads/Tvo_2013_2_3.pdf

82. Степова О.В., Рома В.В. Особливості інтегрування екологічної освіти в навчальний процес закладів вищої освіти. URL: http://reposit.nupp.edu.ua/bitstream/PoltNTU/5807/1/27.pdf

83. Реймерс Н.Ф. Экология: теории, законы, правила, принципы и гипотезы. Москва : Россия молодая, 1994. - 367 с.

84. Степаненков С.Н. О современном состоянии и перспективах развития высшего экологического образования в Украине / Збірник матеріалів навчально 
PEDAGOGY IN MODERN CONDITIONS

методичного семінару «Сучасний стан навчально-методичного забезпечення підготовки екологів». - Херсон, 2014. - С. 3-10.

85. Крисаченко В.С. Екологія. Культура. Політика: концептуальні засади сучасного розвитку / В.С. Крисаченко, М.І. Хилько. - К.: Знання - 2001.

86. Самохвалова А.І., Онищенко Н. Г. Вища екологічна освіта в Україні та принципи іï якісного забезпечення / А.І. Самохвалова, Н.Г. Онищенко // Освіта і наука у мінливому світі: проблеми та перспективи розвитку. Матеріали Міжнародної наукової конференції. 29-30 березня 2019 р., м.Дніпро. Частина I. / Наук. ред. О.Ю.Висоцький. - Дніпро: СПД «Охотнік», 2019. - С. 86 - 87.

87. Madani, R. (2019). Analysis of Educational Quality, a Goal of Education for All Policy. Higher Education Studies; Vol. 9, No. 1, 100-109.

88. Medvid, M., Komisarov, O., Merdova, O. (2018) Review of the tasks of formation and progress of human resources in the sustainable development strategy of Ukraine in the light of central place theory. Baltic Journal of Economic Studies, 2018, 4 (2), 134-140.

89. Соціальна компетентність особистості: соціально-рольовий підхід. Семінар-практикум для соціальних педагогів. https://www.school304.com.ua/?page=484 (24.11.2020)

90. Ковальчук, В. (2002). Соціальна компетентність вчителя як складова професійно-педагогічної компетентності. Соціалізація особистості: Збірник наукових праць. 2002, Т. XVIII, 70-76.

91. Положення про стейкхолдерів ХНПУ імені Г. С. Сковороди. http://hnpu.edu.ua/sites/default/files/files/monitoring/polozhenya\%20pro\%20STEYK HOLDERIV.pdf (22.11.2020).

92. Анкета для опитування роботодавців в галузі 01 Освіта/Педагогіка. https://docs.google.com/forms/d/17bRd-UAtmqabxocSjXO2916yG7wSsUAdLWRr6V_wdc/viewform?edit_requested=true. (20.11.2020).

93. Щудло, С. (2010) Якість освіти як соціологічна проблема. Наукові праці Чорноморського державного університету імені Петра Могили, 2010, Т. 146, Вип. 133, 70-73. 
PEDAGOGY IN MODERN CONDITIONS

94. Щудло С. А. Механізми формування соціальних конвенцій у вищій освіті як умова забезпечення іiі якості S.P.A.C.E. Society, Politics, Administration in Central Europe, 2016, Вип. 1, 31-37.

95. Якість освіти. https://mon.gov.ua/ua/tag/yakist-osviti (24.11.2020).

96. Закон України «Про вищу освіту». https://zakon.rada.gov.ua/laws/show/1556-18\#Text (19.11.2020).

97. Вікторов, В. (2006) Проблема управління якістю освіти (соціальнофілософський аналіз). Мультиверсум. Філософський альманах, 2006, № 52. Https://www.filosof.com.ua/jornel/m_52/viktorov.htm

98. Клімова Г. Якість вищої освіти: європейський вимір. Вісник Національного університету "Юридична академія України імені Ярослава Мудрого", 2016, № 1, 203-210.

99. Агаларова, К. Конспект лекцій з курсу «Соціологія освіти та виховання». Харків, 2016, 97 с.

100. Ніла Йосипівна Волошина : бібліогр. покажч. / НАПН України, Держ. наук-пед. б-ка України імені В. О. Сухомлинського ; [упоряд: Павленко Т. С., Кирій С. В., Бондаренко В. В. ; наук. ред. Рогова П. І. ; наук. рец. Логвіненко Н. М. ; бібліогр. ред. Пономаренко Л. О. ; літ. ред. Зозуля С. М.]. - К. : Задруга, 2010. - 200 с. (Сер. «Ювіляри НАПН України» ; вип. 28).

101. Гладишев В. В.Нотатки про методичну школу Н. Й. Волошиної / В. В. Гладишев // П’яті Волошинські читання. Творча майстерня Ніли Волошиної у проспекції філологічного простору Нової української школи : тези доповідей Усеукраїнської науково-практичної конференції (м. Миколаїв, 22-25 червня 2017 року). - Миколаїв: ОІППО, 2017. - С. 34-36.

102. Козак Л.В., Бухал Л.Г. Закономірності використання інтеграційних форм організації роботи зі старшими дошкільниками. Науковий фаховий журнал «Інноваційна педагогіка» Випуск 18/2019 Т3. С.164-168

103. Bronfenbrenner, Urie (1979), The Ecology of Human Development: Experiments by Nature and Design. Cambridge, MA: Harvard University Press. 321 p. 
PEDAGOGY IN MODERN CONDITIONS

104. Maine, Erica (2013), Parental perceptions of nondisabled preschoolers in inclusive classroom settings. East Carolina University, ProQuest Dissertations Publishing. $50 \mathrm{p}$ [Online], available at: https://search.proquest.com.vlib.interchange.at/pqdtglobal/results/3B59B87619F3424 2PQ/1?accountid=172684 (Accessed: 28 May, 2020).

105. Elliott, Gloria Horton (1997), An investigation into a movement education program on motor creativity in preschool children in inclusive and general physical education environments PH D dissertation. The Ohio State University, ProQuest Dissertations Publishing. $147 \mathrm{p}$ [Online], available at: https://search.proquest.com.vlib.interchange.at/pqdtglobal/results/CF2B9F08DD2242 22PQ/1?accountid=172684 (Accessed: 28 May, 2020).

106. Maeda, Julienne K. (1999), Effects of expert coaching on teacher behaviors of preservice adapted physical educators and the collateral effects on student engagement and motor skill acquisition of preschoolers with and without disabilities in an inclusive context dissertation. The Ohio State University, ProQuest Dissertations Publishing. $212 \mathrm{p}$ [Online], available at: https://search.proquest.com.vlib.interchange.at/pqdtglobal/results/4F1E2D1FB0B44A E9PQ/1?accountid=172684 (Accessed: 28 May, 2020).

107. Hooper, Belinda Bourne (2011), Preparing early childhood special educators for inclusive practice. Virginia Commonwealth University Richmond, Virginia, ProQuest Dissertations Publishing, USA. 189 p. [Online], available at: https://search.proquest.com.vlib.interchange.at/pqdtglobal/results/90EE7FF156B44B 55PQ/1?accountid=172684 (Accessed: 28 May, 2020).

108. California State University, Fullerton, ProQuest Dissertations Publishing. [Online], available at: https://search.proquest.com.vlib.interchange.at/pqdtglobal/results/550177DC17C447 22PQ/1?accountid=172684 (Accessed: 28 May, 2020).

109. Cox, Kathy M. (2010), The case for inclusion: a study of the development of inclusive preschool programs for children with disabilities. University of La Verne, ProQuest Dissertations Publishing. 154 p. [Online], available at: 
PEDAGOGY IN MODERN CONDITIONS

https://search.proquest.com.vlib.interchange.at/pqdtglobal/results/7EAB0170DEB94 B6EPQ/1?accountid=172684 (Accessed: 28 May, 2020).

110. Angell, James Rowland. American Education: Addresses and Articles.- New York: Books for Universities Press, 1970. - P. 260-262

111. Aydelotte, Frank. Oxford Stampand Other Essays: Articles from the Educational Creed of an American Oxonian. - New York: Oxford University Press, 1917 - P.5-6.

112. Baker, Ray Stannard. Woodrow Wilson: Life and Letters.- Garden City, N.Y.: Doubleday, Page, 1939.- P. 215

113. Corbin, John. American at Oxford. - Boston: Houghton - Mifflin. 1902. - P. 302.

114. Duke, Alex. Importing Oxbridge: English residential colleges and American universities. - New Haven; London: Yale Univ. Press, 1996. - P. 119-175.

115. Flexner, Abraham. The American College: A Criticism.- N.Y.: Century, 1908.- P. 374

116. Harvard University Committee on the Objectives of a General Education in a Free Society.- Cambridge, Mass., 1945.- P. 191.

117. Leitch, Alexander. A Princeton Companion. - Prince: Princeton University Press, 1978. - P.374.

118. Myers, William Starr. Woodrow Wilson: Some Princeton Memories. Princeton University Press, 1946. - P.83.

119. Perkins H. P. The Impersonal Oxford // Association of American Colleges Bulletin 16, May 1930. - P. 47.

120. Pierson, George Wilson. Yale: The University College, 1921. - 37.- New Haven: Yale University Press, 1955.- P. 208-216.

121. Slosson, Edwin. Great American Universities.- N.Y.: Macmillan, 1912.- P. 12-18.

122. С.С. Прокоф'єв. Автобіографія. - М.,1982

123. Олійник Леся. Степовий хлопчик. Сергій Прокоф’єв і Україна - Газета «День» № 224, 2014. 
PEDAGOGY IN MODERN CONDITIONS

124. М.Мендельсон-Прокоф'єва. О Сергее Сергеевиче Прокофьеве. Воспоминания. Дневники (1938 - 1967) - М.: Композитор, 2012.- 723 с.

125. Прокофьев С.С. Мой первый педагог / С.С.Прокофьев // Рейнгольд Морицевмч Глиэр. Статьи. Воспоминания. Материалы. - М.-Л., 1965. Т 1.- С. 53.

126. Вишневецкий И. Сергей Прокофьев. - М.: Молодая гвардия, 2009. 703[1] с.: ил. — (Жизнь замечательных людей, вып. № 1200). / Вишнецький Ігор. Прокофьев-стихотворец. Вірш відісланий з Києва Елеонорі Дамській.

127. Енциклопедія історії України ( Т. 5: Кон - Кю ) в електронній біблотеці. Бібліографічне посилання: Васильєв В.Ю. КОТОВСьКИЙ Григорій Іванович [Електронний ресурс] // Енциклопедія історії України: Т. 5: Кон - Кю / Редкол.: В. А. Смолій (голова) та ін. НАН України. Інститут історії України. - К.: В-во «Наукова думка», 2008. - 568 с.: іл.

128. Нестьєва М. Прокофєв солнечний гений

129. Соловьева Г. Прокофьев / Г. Соловьева. - СПб. : Азбука- Классика, Нота МИ. - 2004. - 96 с.: ил. - (Имена на всю жизнь).

130. Персон Д. Концерты, поездки, встречи / Д. Персон. // Рейнгольд Морицевич Глиэр. Статьи. Воспоминания. Материалы. А 2-х томах.- Л., 1965, 1967.

131. Шестаковська Т. Л. Концептуальні засади функціонування організаційно-економічного механізму розвитку національної системи освіти // Науковий вісник Полісся. 2015. № 1. С. 34-41.

132. Конституція України Закон України № 254 к/96-ВР від 28.06.1996. [Електронний ресурс] Режим доступу: http: //zakon5.rada.gov.ua/laws/show/254k/96-вр.

133. Про освіту: Закон України № 1060-XII від 01.01.2014 // База даних «Законодавство України» Режим доступу: http: //www.zakon4.rada.gov.ua.

134. Grinder Dzhon, Richard Bendler, Dzhudit Deloze (1977). Shablony gipnoticheskih metodov Miltona H. Eriksona M.D. [Patterns of the Hypnotic Techniques of Milton H. Erickson M.D]. (Vols. 1-4). Kaliforniya: Meta Publications [in English]. 
PEDAGOGY IN MODERN CONDITIONS

135. Bart R. (1989). Izbrannyie rabotyi: Semiotika: Poetika [Selected Works: Semiotics: Poetics]. Moskva: Progress [in Russian].

136. Bahtin M. M. (1979). Estetika slovesnogo tvorchestva[Aesthetics of verbal creativity]. Moskva: Iskusstvo [in Russian].

137. Blonskiy P. P. (1969). Bolshaya sovetskaya entsiklopediya[Great Soviet Encyclopedia].(Vols. 1-30). Moskva: Sovetskaya entsiklopediya [in Russian].

138. Gumboldt V. fon. (1984). Izbrannyie trudyi po yazyikoznaniyu [Selected Works on Linguistics]. Moskva. [in Russian].

139. Balakhonov, A. V. (2006). Fundamentalization of higher medical education. Bulletin of St. Petersburg University. Series 11. Medicine, (1).

140. Terent'ev, I. G., Abelevich, A. I., \& Svetozarsky, S. N. (2011). Scientific potential of a medical student. Higher education in Russia, (12).

141. Konyshko, N.A., \& Matuskov, M.A. (2015). The concept of designing the practical training of specialists with higher medical education. Bulletin of the Smolensk State Medical Academy, 14 (2).

142. Zakhidna, O. R., \& Midlik, Y. I. (2017). Medical reform under conditions of powerd decentralization in Ukraine. Young Scientist (Molodyi vchenyi), (11), 11551158.

143. Denisyuk, N.V. O. P.O. (2014). Introduction of unconventional teaching methods as a means of preparation of a new genereation of medical students. Medical education, (4).

144. Яременко М. Ю. Інформаційна картина світу як соціокультурна реальність // Наука. Релігія. Суспільство. - 2008. - № 1. - С. 234-239.

145. Колотило В. В. Сучасна картина світу і світогляд людтни // Філософські проблеми гуманітарних наук. - К.: Київський університет, 2010. - № 19. - С. 156-160.

146. Чернова Л.П. Наукова картина світу як предмет філософського дискурсу // «Гілея: науковий вісник»: Збірник наукових праць. - К., 2010. - Вип. 40 (10). Електронне видання. Режим доступу: http://www.nbuv.gov.ua/portal/Soc_Gum/Gileya/2010_40/Gileya40/F10_doc.pdf 
PEDAGOGY IN MODERN CONDITIONS

147. Сидоренко В. К. Роль школи в підготовці учнів до вибору педагогічної професії // Педагогічний альманах. - 2010. - Вип. 6. - С. 242-249.

148. Кузьменко В. В. Теоретичні і методичні засади формування в учнів наукової картини світу в історії розвитку шкільної освіти (XX століття). Автореферат дис. док. пед. наук. - Тернопіль, 2009. - 42 с. Режим доступу: http://www.nbuv.gov.ua/portal/soc_gum/pedalm/kuzmenko_avt.pdf

149. Ашиток Н. І. Мовна картина світу з позицій освітніх викликів сучасності // «Гілея: науковий вісник»: Збірник наукових праць. - К., 2010. - Вип. 37. Режим доступу: //http://www.nbuv.gov.ua/portal/Soc_Gum/Gileya/2011_44/Gileya44/F32_doc.pdf

150. Ашиток Н. І. Морально-ціннісний потенціал мовної картини світу в освітньому аспекті // Людинознавчі студії. Збірник наукових праць ДДПУ імені Івана Франка. - Вип. 21. Педагогіка. - С. 76-85.

151. Голубовська I. О. Етноспецифічні константи мовної свідомості: Автореф. дис... д-ра філол. наук: 10.02.15. Київський національний ун-т ім. Тараса Шевченка. - К., 2004. - 36 с.

152. Мосенкіс Ю. Л. Семантична проблематика у спецкурсі «Дослідження 3 етимології» // Проблеми семантики слова, речення та тексту: Зб. наук. праць. К.: Видавничий центр Київського національного лінгвістичного університету, 2004. - С. $180-182$.

153. Бергсон А. Две формы // Хрестоматия по общей психологии. Психология памяти. - М., $1979 . \quad$ - С.61-75. - Режим доступа: http://filosof.historic.ru/books/item/f00/s00/z0000152/index.shtml

154. Новое в лингвистике. Вып. IV. Сост. В. А. Звегинцев. - М.: Прогресс, 1965.

155. Хэгболдт П. Изучение иностранных языков Некоторые размышления из опыта преподавания. Сокращенный перевод с англ. Л. А. Морозовой. - М.: Учпедгиз, 1963. - $160 \mathrm{c.}$

156. Маслоу А. Мотивация и личность. Пер. А. М. Татлыбаевой. - СПб.: Евразия, 1999. - Режим доступа: http://psylib.org.ua/books/masla01/index.htm 
PEDAGOGY IN MODERN CONDITIONS

157. Панов Е. Н. Знаки. Символы. Языки. Изд. 2-е, доп. - М.: Знание, 1983. $248 \mathrm{c}$.

158. Жоль К. К. Язык как практическое сознание (философский анализ). - К.: «Выща школа», 1990. - 238 с.

159. Хоккетт Ч. Грамматика для слушающего. Пер. с англ. В. В. Лазарева // Новое в лингвистике. Вып. IV. - М.: Прогресс, 1965. - С.139-166.

160. Ингве В. Гипотиза глубины // Новое в лингвистике. Вып. IV. - М.: Прогресс, 1965. - С .126-138.

161. Общая психология: Учеб. пособие для студентов пед. институтов / В. В. Богословский, А. А. Степанов, А. Д. Виноградова и др. - 3-е изд., перераб. и доп. - М.: Просвещение, 1981. - 383 с .

162. Вакулик I. I., Пузиренко Я. В. Культура ділового та сімейного спілкування: інтерактивні вправи, завдання, тести: Навчальний посібник. - К.: Центр інформаційних технологій, 2007. - 150 с.

163. Культура сім'ї та побуту: наукове видання / I. 3. Майданюк [та ін.]; Національний університет біоресурсів і природокористування України. - К. : НУБіП України, 2014. - 365 с.

164. Захарова И. Г. Информационные технологии в образовании: Учеб. пособие для студ. высш. пед. учеб. заведений. - М.: Издательский центр «Академия», 2003. - 192 с.

165. Кашина Е.Г. Традиции и инновации в методике преподавания иностранного языка: учеб. пособие для студентов филологических факультетов университетов / Ред. А. С. Гринштейн. - Самара: Изд-во «Универсгрупп», 2006. - 75 с.

166. Выготский Л. С. Воображение и творчество в детском возрасте. - М., 1991. $-350 \mathrm{c}$.

167. Федоров А. В. О задачах сопоставительного изучения языков // Немецкорусские языковые параллели. - М., 1961. 
PEDAGOGY IN MODERN CONDITIONS

168. Васыгова М.Ф. О некоторых аспектах контрастивной лингвистики // Общее и сопоставительное языкознание. Под ред. Г. И. Раптовой. - М.: Издательство Московского университета, 1986. - С. 17-29.

169. Іванченко Р. Г. Адекватність розуміння і ясність тексту. - К.: Товариство «Знання» України, 1991. - 48 с.

170. Журавель В.Ф., Ільїн В. В., Кузнецов В. О., Сухарніков Ю. В. Рекомендована практика конструювання тестів професійної компетенції випускників вищих навчальних закладів /За загал. ред. Ю. В. Сухарнікова - К.: Аграрна освіта, 2000. - 38 с.

171. Гончаренко С. Український педагогічний словник. Київ: Либідь, 1997. с. 376.

172. Нісімчук А., Падатка О., Шпак О. Сучасні педагогічні технології: навч. посіб. Київ : Видавничий центр «Просвіта», Пошуково-видавниче агентство «Книга Пам’яті України», 2000. 368 с.

173. Педагогічні технології: наука - практиці: навч.-метод. щорічник / О. Кульчицька, С. Сисоєва, Я. Цехмістер; за ред. С. О. Сисоєвої. Київ: ВШОЛ, 2002. Вип. $1.281 \mathrm{c.}$

174. Савченко О. Школа культури - діалог з В.О. Сухомлинським. Початкова школа. 2006. № 12. С. 1-5.

175. Сисоєва С. Основи педагогічної творчості : підручник. Київ, 2006. 240 c.

176. Нежинская Т.А., Глазырина Е.Ю. Характеристика компонентов, показателей и критериев диагностики сформированности специальных профессиональных компетенций // Вестник Кемеровского государственного университета культуры и искусств. - 2018. - №42. - С. 103-109.

177. Zelinskiy S. Analysis of the possibilities of the MOODLE learning management system for organization of distance learning in the conditions of the university // Scentific Journal «ScienceRise: Pedagogical Education». - 2020. №5(38). - C.33-36. 
PEDAGOGY IN MODERN CONDITIONS

178. Зелинский С.С. Информационно-коммуникационные технологии ВУЗа: проблемы и перспективы // X Международная научно-практическая конференция «Eurasian scientific congress». Barca Academy Publishing. Barcelona, Spain. - 2020. - C.200-203.

179. Зелинский С.С. Информатизация ВУЗа: теоретические аспекты // IV Международная научно-практическая конференция «ACTUAL TRENDS OF MODERN SCIENTIFIC RESEARCH». MDPC Publishing. Munich, Germany. 2020. - C.198-201.

180. Ягодзінський С. М. Традиції та інновації в науковому дискурсі. Totallogy-XXI. Постнекласичні дослідження : наук. зб. Київ : ЦГО НАН України, 2003. C. $150-163$.

181. Сноу Ч. П. Портреты и размышления. Москва : Прогресс, 1985. С. 195226. URL: http://vivovoco.astronet.ru/VV/PAPERS/ECCE/SNOW/TWOCULT.HTM

182. Койре А. Очерки истории философской мысли. Москва : Прогресс, 1985. $140 \mathrm{c}$.

183. Стуканов М. А. Опозиція явного і неявного знання у соціальному, історичному і культурному контекстах. Людинознавчі студії. Серія: Філософія. 2017. Вип. 34. С. 90. URL: http://nbuv.gov.ua/UJRN/Lstudf_2017_34_10.

184. Полани М. Личностное знание. На пути к посткритической философии. Москва : Наука, 1985. 343 с. URL: http://www.lib.tsu.ru/win/dokument/Inforobrazov_portfel/Polani_M_Lichnostnoe_znanie_1985.pdf.

185. Хайек Ф. Контрреволюция науки. Этюды о злоупотреблении Разумом. Москва : ОГИ, 2003. 288 c. URL: http://www.libertarium.ru/contrrev.

186. Gardner H. Truth, beauty, and goodness reframed: Educating for the virtues in the 21 st century. New York : Basic Books, 2011.

187. Скрипченко О.В., Долинська Л.В., Огороднійчук 3.В. Загальна психологія. К.: Каравела, 2007. 640 с.

188. Корнієць Н.В., Вовк О.В. Сучасні прийоми верстки та дизайну як засоби підвищення ефективності сприйняття навчального матеріалу // Поліграфічні, мультимедійні та web-технології: матеріали Молодіжної школи-семінару V 
Міжнародної науково-технічної конференції (3 листопада 2020, м. Харків). Т.2. C. 31-34.

189. Поперечна Л., Терещенко А. Видова різноманітність навчальних видань // Шк. бібл.-інформ. центр. - ШБІЦ. Бібл. робота. 2012. № 2. С. 39-46.

190. Kuznetsova I., Vovk O. Technology of Educational Electronic Publications' Quality Evaluation // Center for Open Access in Science (COAS). Open Journal for Information Technology (OJIT) Belgrade, SERBIA. URL: http://centerprode.com/ ojit/ojit0201/coas.ojit.0201.02009k.pdf

191. Писаренко Н.О. Дослідження продуктивного запам'ятовування як умови активної розумової діяльності і творчої самостійності // Науковий вісник Мелітопольського державного педагогічного університету ім. Б. Хмельницького. Серія: «Педагогіка». 2010. № 4. С. 86-93.

192. Теоретические основы создания образовательных электронных изданий / М.И. Беляев, В.М. Вымятнин, С.Г. Григорьев и др. Томск: Изд-во Том. ун-та, 2002. 61c.

193. Румянцев В.Н. Неисправности и их устранение в листовой офсетной печати. М .: ПРИНТ-МЕДИА центр, 2006. 166 с.

194. Деджидас Л., Десятеро Т. Листовая офсетная печатная машина: механизмы, эксплуатация, обслуживание. М .: ЦАПТ, 2007. 488 с.

195. Молчанова, Н.А. Розробка структури тренажера // Радіоелектроніка i молодь в XXI столітті: матеріали 20-го Міжнародного молодіжного форуму (1921 квітня 2016, Харків). 2016. Т. 6. С. 423-424.

196. Григор'єв О.В., Турчинова Г.І., Григор'єва О.В. Система формування знань і умінь по експлуатації та обслуговуванню поліграфічного обладнання за допомогою програм-тренажерів // Поліграфічні, мультимедійні та webтехнології: тез. докл. 1-й Міжнарод. наук.-техн. конф. (16-20 травня 2016, Харків). 2016. Т. 1. С. 33-34.

197. Грицишина Н. А. Технология «воркшоп» как одна из новых форм и методов обучния студентов иностранному языку. Альманах современной науки и образования. Тамбов : Грамота, 2012. № 3 (58). С. 49-51. 
198. Коновальчук I. I. Інформаційно-комунікаційні технології у сучасних моделях інноваційних освітніх процесів. Інформаційні технології і засоби навчання. 2015. Т.46. № 2. С. 124-131.

199. Кошечко Н. Інноваційні технології навчання та викладання у вищій школі. Вісник Київського національного університету імені Тараса Шевченка. Педагогіка. 2015. Вип 1. С. 35-38.

200. Литвиненко С. А. Використання воркшопів у підготовці майбутніх психологів до професійної діяльності. Оновлення змісту, форм та методів навчання і виховання в закладах освіти : збірник наукових праць ; Наукові записки Рівненського державного гуманітарного університету. Рівне : РДГУ, 2014. Вип. 9 (52). С. 10-12.

201. Гончаренко С. У. Український педагогічний словник. Київ : Либідь, 1997. $376 \mathrm{c}$.

202. Пєхота О. М., Кіктенко А. 3. , Любарська О. М. та ін. Освітні технології : навч.-метод. посіб. Київ: А.С.К., 2002. 255 с.

203. Інтерактивні технології навчання: теорія, практика, досвід: наук.-метод. посібн. / О. Пометун, Л. Пироженко та ін. за ред. О. Пометун. Київ: А.С.К., 2004. 192 c.

204. Кудирко О. В. Воркшоп: сутність та методичні особливості застосування на практичних заняттях студентів ВНЗ. Від викладання дисциплін - до освоєння наук: трансформація змісту, технологій освітньої діяльності та розвиток педагогічної майстерності : зб. матеріалів наук.-метод. конф., 31 січ. 2013 р./ [редкол.: А. М. Колот, О. І. Олексюк, Т. В. Гуть]. Київ : КНЕУ, 2013. С. 338.

205. Петухова Л. Є., Співаковський О. В. Актуальні питання формування інформатичних компетентностей майбутніх учителів початкових класів. Комп'ютер у школі та сім’ї. 2011. №1. С. 7-11.

206. Фопель К. Ефективний воркшоп. Динамічне навчання ; пер. 3 нім. Москва : Генезис, 2003. 368 с.

207. Намакштанська І. С., Новикова Ю. М., Назар Р. М. Інноваційні методики викладання державної мови у вищих навчальних закладах технічного профілю. 
PEDAGOGY IN MODERN CONDITIONS

Інформаційні технології і засоби навчання. 2009. № 6(14). URL: http://journal.iitta.gov.ua/index.php/itlt/article/view/221/207 (дата звернення: 24.11.2020).

208. Дичківська І. М. Інноваційні педагогічні технології : навч. посібник. Київ : Академвидав, 2004. 352 с.

209. Дубасенюк О. А Інноваційні навчальні технології - основа модернізації університетської освіти. Освітні інноваційні технології у процесі викладання навчальних дисциплін : зб. наук.метод праць / За ред. О. А. Дубасенюк. Житомир : Вид-во ЖДУ, 2004. С. 3-14.

210. Козяр М. Інноваційні технології навчання в діяльності ВНЗ. Проблеми та перспективи формування національної гуманітарно-технічної еліти : зб. наук. пр. / ред. Л. Л. Товажнянський, О. Г. Романовський. Харків : НТУ «ХПІ», 2014. Вип. 38-39 (42-43). С. 142-151.

211. Петров С. Воркшоп: новая технология обучения или отдых для тренера? URL: https://newsland.com/user/sergeypetrov/content/vorkshop-novaia-tekhnologiiaobucheniia-ili-otdykh-dlia-trenera/5404996 (дата звернення: 24.11.2020).

212. Абасалієва О. Воркшоп як форма виховання етнічної свідомості. Матеріали III Міжнароної дистанційної науково-практичної конференції «Наукові пошуки XXI століття: молодіжний вимір (м. Київ, 2 жовтня 2015 р.). Київ, 2015. С. 10-14.

213. Запорожець О. О. Бібліотечний воркшоп як метод упровадження інтерактивних технологій. Шкільний бібліотекар. 2015. № 7. С. 3-6.

214. Боринець Н. І. Технологія воркшопу в трудовому навчанні : презентація. URL: https://www.slideshare.net/ippo-kubg/ss-55431698 (дата звернення: 24.11.2020).

215. Педагогічні технології: теорія та практика : навч.-метод. посібник ; за ред. проф. М. В. Гриньової ПДПУ ім. В. Г. Короленка. Полтава : АСМУ, 2006. $230 \mathrm{c}$.

216. Педагогічні технології у неперервній професійній освіті : монографія / За ред. С. О. Сисоєвої. ВІПОЛ, 2001. 502 с. 
PEDAGOGY IN MODERN CONDITIONS

217. Петренко Л. М. Сучасні тенденції модифікацій педагогічних технологій в освіті дорослих. Витоки педагогічної майстерності : зб. наук. пр. Полтава, 2013. Вип. 11. С. 256-261.

219. Селевко Г. К. Современные образовательные технологии : учебное пособие. Москва: Народное образование, 1998. 589 с.

220. Стрельніков В. Ю., Брітченко І. Г. Сучасні технології навчання у вищій школі : модульний посібн. для слухачів авторських курсів підвищення кваліфікації викладачів МІПК ПУЕТ. Полтава : ПУЕТ, 2013. 309 с.

221. Гузеев, В. В. Инновационные идеи в современном образовании / Гузеев В. В. // Школьные технологии. - 1997. - № 1. - С. 3-10.

222. Селевко, Г. К. Современные образовательные технологии: Учебное пособие образовании / Селевко Г. К. - М., 1998.

223. Вылегжанина, Е. А. Использование информационнокоммуникационных технологий в образовательном процессе / Е. А. Вылегжанина, Н. Н. Мальцева // Актуальные задачи педагогики: материалы VI междунар. науч. конф. (г. Чита, январь 2015 г.). - Чита: Издательство Молодой ученый, 2015. - Библиогр.: с. 4-6.

224. Ковель, М. И. Инновационные процессы в образовании: критериальное оценивание знаний и универсальных учебных действий учащихся в системе способа диалектичекого обучения / М. И. Ковель, Г. В. Глинкина, В. Л. Зорина // Личность, семья и общество: вопросы педагогики и психологии: сб. ст. по матер. VII междунар. науч.-практ. конф. Часть II. - Новосибирск: СибАК, 2011.

225. The English for Universities project [Electronic resource]. - Access mode: http://www.britishcouncil.org.ua/en/teach/projects/english-universities

226. Rod Bolitho and Richard West. The internationalisation of Ukrainian universities: the English language dimension / British Council, Ukraine: English for Universities Project [Electronic resource]. - Access mode: http://www.teachingenglish.org.uk/article/internationalisation-ukrainian-universitiesenglish-language-dimension 
PEDAGOGY IN MODERN CONDITIONS

227. The materials introduced by the British Council at the Teacher Development Schools [Electronic resource]. - Access mode: britishcouncil.org.ua

228. Garmash S. V. Sharing experience in the framework of the project "English for Universities" (objectives and outcomes of training) / S. V. Garmash, V. A. Sadkovska // Південний архів : зб. наук. пр. Філологічні науки = Pivdenniy arkhiv : Coll. papers on Philology / гол. ред. Н. І. Ільїнська. - Херсон : ХДУ, 2017. - Вип. 68. - C. 87-90.

229. Garmash S. V. Dessimination of information in the framework of the British Council "English for Universities" project / S. V. Garmash, V. A. Sadkovska // Одеський лінгвістичний вісник. - 2017. - Вип. 10, т. 2. - С. 125-127.

230. Garmash S. V. Problems and perspectives of ATE in the framework of collaboration with the British Council / S. V. Garmash, V. I. Makarova, V. A. Sadkovska // Науковий вісник Дрогобицького державного педагогічного університету імені Івана Франка : зб. наук. пр. Сер. : Філологічні науки. Мовознавство / гол. ред. О. П. Кушлик. - Дрогобич : ДДПУ, 2017. - Т. 1, № 8. C. 49-52.

231. Про затвердження Положення про дистанційне навчання [Електронний ресурс] : Постанова Кабінету Міністрів України № 466 від 25.04.2013 р. — Режим доступу:http://zakon4.rada.gov.ua/laws/show/z0703-13. —-Назва 3 екрану.

232. Блощинський І.Г, Сутність та зміст поняття «дистанційне навчання» в зарубіжній та вітчизняній науковій літературі // Вісник Національної академії Державної прикордонної служби України, 2015 Випуск 3 file://C:/Users/\%D0\%9E\%D0\%BF\%D0\%B5\%D1\%80\%D0\%B0\%D1\%82\%D0\%BE \%D1\%80/Downloads/Vnadps_2015_3_4.pdf

233. Pedagogy theory: collective monography / Kireyev I.,Zhabotynska N. etc. - International Science Group. - Boston : Primedia eLaunch, 2020. 228-232 p. Available at : DOI : 10.46299/isg.2020.MONO.PED.I

234. https://osvita.ua/vnz/high_school/72285/ 
PEDAGOGY IN MODERN CONDITIONS

235. Moodle[Електронний ресурс]. - Режим доступу:https://moodle.org/. Назва з екрану.

236. Колос К.Р. Система Moodle як засіб розвитку предметних компетентностей учителів інформатики в умовах дистанційної післядипломної освіти : автореф. дис. на здобуття наук. ступеня канд. пед. наук : спец. 13.00.10 Інформаційно-комунікаційні технології в освіті” / К.Р. Колос. —К., 2011. - 21с.

237. Мищишен А. В. Moodle як система дистанційного управління навчанням при підвищенні

кваліфікації

file://C:/Users/Roman/Downloads/Vpo_2011_5_15.pdf

238. https://naurok.com.ua/post/model-navchannya-perevernutiy-klaszminyuemo-osvitniy-proces

239. Staker H., Horn M.B. Classifying K-12 Blended Learning By https://files.eric.ed.gov/fulltext/ED535180.pdf

240. Л. В. Галий, Л. И. Шульга, В. А. Якущенко, П. В. Нартов*, Е. А. Бурьян, C. А. Баган Внедрение дистанционной формы обучения в систему последипломного образования: проблемные вопросы современности // Проблеми безперервної медичної освіти та науки №3 (35)’ 2019 с. 14-20

241. Гуревич Р.С. Освітне середовище для підготовки майбутніх педагогів засобами ІКТ: [монографія] / Р.С. Гуревич, Г.Б. Гордійчук, Л.Л. Коношевський, О.Л. Коношевський, О.В. Шестопал; за ред. проф. Р.С. Гуревича. - Вінниця: ФОП Рогальська I.O., 2011. - 348 с.

242. Маслюк Л.П. Новые технологии в процессе обучения иностранным языкам // Вестник ХНАДУ. - 2009. - № 44. - С. 12-14.

243. Content and Language Integrated Learning (CLIL) at School in Europe [Electronic resource] - Mode of access: http://ec.europa.eu/languages/documents/studies/clilat-school-ineurope_en.pdf

244. Coyle D., Hood Ph., Marsh D. CLIL: content and language integrated learning. Cambridge: Cambridge University Press, 2010. - 184 p.

245. Ewa M. Golonka. Technologies for foreign language learning: a review of technology types and their effectiveness [Electronic resource] / Ewa M. Golonka, Anita 
PEDAGOGY IN MODERN CONDITIONS

R. Bowles// Computer Assisted Language Learning. - 2012. - Mode of access: http://www.sinocall.org/pdf/Technologies_for foreign-language.pdf

246. Otroshhenko, L. S. Reformuvannya vy`shhoyi osvity` Nimechchy`ny`u konteksti Bolons `kogo procesu / L. S. Otroshhenko // Suchasni tendenciyi rozvy`tku osvity` v Ukrayini ta za kordonom : zb. materialiv Mizhn. naukovo-prakty`ch. konf. Naukovi praci. Seriya : Pedagogika, psy`xologiya i sociologiya. - Donecz`k, 2009. Vy`pusk 5 (155). - S. 62-66.

247. Sixteen (1984). Short Stories by Outstanding Writers for young

248. Adults. Edited by Donald R. Gallo. Dell: Laurel - Leafbooks

249. Hopkins, Felicity. Get Ready! Pupil's Book 1. Step 40. Oxford.

250. Wilde, Oscar. (1979). Fairy Tales. Moscow.

251. Cardoso, Onelio. (1984).The Grasshopper's Song. Translated by

252. Mary Todd. Cuba.

253. Girleanu, Emil. (1985). The Hare. Brown Watson. London.

254. Girleanu, Emil. (1985). In my courtyard Brown Watson. London.

255. Shaw, Irwin. (1988). The Top of The Hill. New English Library.

256. Aue (Sukis) J. (2018). The human-to-machine communication model. Retrieved November, 22, 2020 from https://medium.com/design-ibm/the-human-tomachine-communication-model-d630ec54a12e

257. Borisova, L. (2013). Contemporary Problems of Corporate Communications. ISBN: 978-3-659-40993-6

258. Bissenbayeva, Z., Ubniyazova, S., Saktaganov, B., Bimagambetova, Z., Baytucaeva, A. (2013). Communicative Competence Development Model. Procedia Social and Behavioral Sciences, 82, 942-945. doi: 10.1016/j.sbspro.2013.06.375

259. Beilfus, M., Bettes, St., and Peterson, K. (2019). Technical and Professional Writing Genres: A Study in Theory and Practice.

260. Chernysh, V. (2018). Competence-Based Approach to the Development Of Professionally Oriented Communicative Competence of Foreign Languages TeacherTrainees in the Intercultural Context. Development trends in pedagogical and 
psychological sciences: the experience of countries of Eastern Europe and prospects of Ukraine. DOI: 10.30525/978-9934-571-27-5_59

261. De Corte, E., Verschaffel, L., \& Masui, C. (2004). The CLIA-model: A framework for designing powerful learning environments for thinking and problem solving. European Journal of Psychology of Education, 19, 365-384.

262. Enache, R. Crişan, A. (2014) Communication, Networking and Personal Development Skills Trained During the Educational Process. Procedia - Social and Behavioral Sciences, 159 (2014), 524 - 528. doi: 10.1016/j.sbspro.2014.12.417

263. Future of Jobs Report. World Economic Forum. Retrieved November 22, 2020 from https://www.weforum.org/

264. John, N. (2018). Developments in information technology. Retrieved November, 22, 2020 from https://medium.com/@niyajohn9495/developments-ininformation-technology-b93c74b7bd79

265. Henry-Nickie, M., Frimpong, K., and Sun H. (2019). Trends in the Information Technology sector. Report. Retrieved November, 20, 2020 from https:/www.brookings.edu/research/trends-in-the-information-technology-sector/

266. Lambin, J. (2014). An Innovative Economy. Rethinking the Market Economy. Ed. Macmillan, P. London. https://doi.org/10.1057/9781137392916_5

267. Lesiak-Bielawska, E. D., (2015). Technology in ESP Pedagogy. English for Specific Purposes World, 48, v.16. ISSN 1682-3257

268. Roco, M., Bainbridge, W. (2004). Converging Technologies for Improving Human Performance: Nanotechnology, Biotechnology, Information Technology and Cognitive Science. Arlington: National Science Foundation.

269. Rubtsov, V. (2015). V.V. Davydov - the founder of significant scientific school and director of the Psychological Institute. Psychological Science and Education, 20(3), 182-196. DOI: 10.17759/pse.2015200320

270. Simkova, I., Medvedchuk, A., Vaynahiy, T. The Implementation of E-campus during the Assessment of English for Specific Purposes. Universal Journal of Educational Research, 8(6): 2444-2454, 2020. DOI: 10.13189/ujer.2020.080628

271. Toffler, A., Toffler, H. (2006). Revolutionary Wealth. New York. 
PEDAGOGY IN MODERN CONDITIONS

272. Vahabi, M. Sadeh, N. (2011). An investigation of ICT role in ESP. An implication for technical education. Confluence: international e-journal on teaching of English in technical education. ISSN: 2250-138X

273. Aronson L. (2011) Twelve tips for teaching reflection at all levels of medical education. Medical Teacher; vol. 33, no. 3, pp. 200 - 205.

274. Cook D.A., Beckman T.J., Bordage G. (2007) Quality of reporting of experimental studies in medical education: A systematic review. Med. Educ. vol. 41, pp. 737-745.

275. Cook D.A., Bordage G., Schmidt H.G. (2008) Description, justification, and clarification: A framework for classifying the purposes of research in medical education. Med. Educ. vol. 42, pp. 128 - 133.

276. Gruppen L.D. (2008) Is medical education research "hard" or "soft" reseach? Adv. Health Sci. Educ. Theory Pract. vol. 13, no. 1, pp. 1 - 2.

277. Lewkonia R. (2011) Patient rights and medical education: Clinical principles. Medical Teacher. vol. 33, no. 5, pp. 392 - 396.

278. Lindgren S., Brannstrom T., Hanse E. et al. (2011) Medical Education in Sweden. Medical Teacher. vol. 33, no. 7, pp. 798 - 803.

279. Pericleous S. (2011) Undergraduate medical education in Cyprus: The introduction of two medical schools. Medical Teacher, vol. 33, no. 7, pp. 530 - 534.

280. Solomon P. (2011) Student perspectives on patient educators as facilitators of interprofessional education. Medical Teacher, vol. 33, no. 10, pp. 851 - 853.

281. Tavakol M., Dennick R. (2011) Post-examination analysis of objective test. Medical Teacher. vol. 33, no. 6, pp. 455 - 458.

282. Turkeshi E. (2011) Medical education in Albania: Challenges and opportunities. Medical Teacher. vol. 33, no. 5, pp. 437 - 442.

283. Holovchak I. S. (2015) Suchasna lekzija [Modern lecture] Galic'kij likars'kij visnik. vol. 22, no. 1, pp. 100 - 101 (in Ukrainian).

284. Vydyborets S. V., Gaidukova S. M., Guseva S. A., Kucher O. V., Sergienko O. V., Remennik O.I. et al. (2012) Rol' lekziji u meduchnij pisljadyplomnij osviti [The 
PEDAGOGY IN MODERN CONDITIONS

role of lecture in medical post-graduate educaton]. Ukrajinskij zurnal gematologii i transfusiologii. no. 6(17), pp. 5 - 8 (in Ukrainian).

285. Mokija-Serbina S. O. (2015) Lekzija kak forma obuchenja v profesionalnom obrasovanii vrachej-pediatrov [Lecture as a teaching method in occupational education of pediatric physicians] Galic'kij likars'kij visnik. vol. 22, no. 1, pp. $109-110$ (in Russian).

286. Vydyborets S. V., Sergienko O. V. (2012) Suchasnyj stan pidgotovky likariv za fahom "transfuziologija" $v$ Ukrajini [The current state of physicians training in the specialty "transfusiology" in Ukraine] Ukrajinskij zurnal gematologii i transfusiologii. no. 6(17), pp. 9 - 12 (in Ukrainian).

287. Gibbs T., Durning S., Artino A.R. (2011) Theories in medical education: Towards creating a union between educational practice and research traditions. Medical Teacher. vol. 33, no. 3, pp. 183 - 187.

288. Каленик В. І., Каленик М. В. Питання загальної методики навчання фізики /Пробний навчальний посібник. - Суми: Редакційно-видавничий відділ СДПУ ім. А.С. Макаренка, 2000. - 125с.

289. Каленик М.В. Використання довгострокових завдань з фізики для оцінки практичних умінь старшокласників // Збірник наукових праць. Педагогічні науки. Випуск 24. - Херсон: Айлант, 2001. - С. 198-201

290. Москаленко В.Ф. Модернізація навчальних планів і програм підготовки лікарів відповідно до нової парадигми розвитку Європейського освітнього простору / В.Ф. Москаленко, П.О. Яворівській, І.С. Булах та ін. // Матеріали X

291. Всеукраїнської навчально-наукової конференції з міжнародною участю «Кредитно-модульна система організації навчального процесу у вищих медичних (фармацевтичному) навчальних закладах України на новому етапі», Тернопіль: ТДМУ, 2013. - Ч. 1. - С. 25-28.

292. Мінцер О.П. Прийняття медичних рішень в умовах ризиків виникнення інформаційної та технологічної сингулярності /О.П. Мінцер, М.В.Банчук, Н.В.Харик// Системи підтримки прийняття рішень.-2013.-Теорія і практика.C.100-103. 
PEDAGOGY IN MODERN CONDITIONS

293. Журавська Л. М. Концептуальні умови управління самостійною роботою студентів у ВНЗ / Журавська Л. М. // Освіта та управління. - Т. 3. - 1999. - №2.

294. Морозова О. М. Пошук стандартів вищої медичної освіти для вдосконалення системи охорони здоров'я / О.М. Морозова, Л. В. Батюк, В. Г. Кнігавко // Актуальні питання якості медичної освіти : матеріали ХІІІ Всеукр. наук.-практ. конф. з міжнар. участю. - Тернопіль, 2016. - Т.1. - С. 109-110.

295. Про затвердження Положення про спеціалізацію (інтернатуру) випускників вищих медичних і фармацевтичних закладів освіти III-IV рівня акредитації медичних факультетів університетів: Наказ Міністерства охорони здоров’я України від 19.09.1996 р. № 291 [Електронний ресурс]. - Режим доступу : http://zakon4.rada.gov.ua/laws/show/z0696-96/page2.

296. Загальноєвропейські Рекомендації 3 мовної освіти: вивчення, викладання, оцінювання / наук. ред. укр. вид. С. Ніколаєва. - К. : Ленвіт, 2003. $273 \mathrm{c}$.

297. Концепція формування іншомовної професійної компетентності майбутніх фахівців природничих спеціальностей Микитенко Наталія Олександрівна, м.Львів Серія «Педагогіка, соціальна робота». Випуск 23.

298. Общая и профессиональная педагогика: учебное пособие : В 2-х кн. / под ред. В. Д. Симоненко, М. В. Ретивых. - Брянск : Изд-во БГУ, 2003. - Кн.1. - 174 c. ]

299. Род Болайто та Річард Вест Інтернаціоналізація українських університетів у розрізі англійської мови: Проект «Англійська мова для університетів» / Род Болайто та Річард Вест. - К.:«Видавництво «Сталь», 2017. $-154 \mathrm{c}$.

300. Сура Н. А. Навчання студентів університету професійно орієнтованого спілкування іноземною мовою: автореф. дис. ... на здобуття наук. ступеня канд. пед. наук: 13.00.04 / Н. А. Сура ; Луган. нац. пед. ун-т ім. Т.Шевченка. - Луганськ, 2005. $-20 \mathrm{c}$. 
PEDAGOGY IN MODERN CONDITIONS

301. Бацевич Ф.С. Основи комунікативної лінгвістики: підручник/ Ф.С. Бацевич //- К.: Академія, 2004. - 318 с.

302. Дичківська I.M. Інноваційні педагогічні технології : навчальний посібник/ І.М. Дичківська //- К.: Академвидав, 2004. - 351 с.

303. Жалдак М.I. Компютер на уроках математики. Посібник для вчителів/ М.І. Жалдак//- К.: Техніка, 1997. - 303 с.

304. Андреев В. И. Педагогика: Учебный курс для творческого саморазвития : 3-е изд. Казань: Центр инновационных технологий, 2012. 608 с.

305. Бегидова С. Н. Теоретические основы профессионально-творческого развития личности : М.; Майкоп : Адыг. гос. ун-т, 2001. 269 с.

306. Библер В. С. Мышление как творчество. (Введение в логику мысленного диалога) : М.: Политиздат, 1975. 399 с.

307. Вербицкий А. А. Активное обучение в высшей школе: контекстный подход: метод. пособие. М.: Высшая школа, 1991. 207 с.

308. РРогачева, Е. Ю. Педагогика Джона Дьюи в XX веке: кросс-культурный контекст : монография. Владимир, 2005. 332 с.

309. Роджерс К. Творчество как усиление себя. Вопросы психологии.1990. №1. C. 164-168.

310. Цюряк I. О. Методика застосування особистісно орієнтованих технологій навчання в процесі диригентсько-хорової підготовки майбутнього вчителя музики : дис. ... канд. пед. наук : 13.00 .02 / Нац. пед. ун-т ім. М. П. Драгоманова, Київ, 2009. 243 с.

311. Garmash S. Two years` experience of working in the framework of the British Council 'English for universities' project (problems and perspectives) / S. Garmash, V. Sadkovska // Південний архів : зб. наук. пр. Філологічні науки = Pivdenniy arkhiv : collected papers on Philology / гол. ред. Н. І. Ільїнська. - Херсон : ХДУ, 2018. Вип. 76. - С. 60-63. 